Technische Universität München

KfW Stiftungslehrstuhl für Entrepreneurial Finance

Univ.-Prof. Dr. Dr. Ann-Kristin Achleitner

\title{
Structure and determinants of financial covenants in leveraged buyouts
}

\author{
Florian T. Tappeiner
}

Vollständiger Abdruck der von der Fakultät für Wirtschaftswissenschaften der Technischen Universität München zur Erlangung des akademischen Grades eines

Doktors der Wirtschaftswissenschaften (Dr. rer. pol.)

genehmigten Dissertation.

\author{
Vorsitzender: $\quad$ Univ.-Prof. Dr. M. Moog \\ Prüfer der Dissertation: 1. Univ.-Prof. Dr. Dr. A.-K. Achleitner \\ 2. Univ.-Prof. Dr. G. Friedl
}

Die Dissertation wurde am 30.09.2010 bei der Technischen Universität München eingereicht und durch die Fakultät für Wirtschaftswissenschaften am 15.12.2010 angenommen. 


\section{TABLE OF CONTENTS}

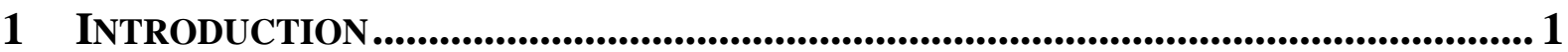

1.1 Relevance and Objectives ............................................................................ 1

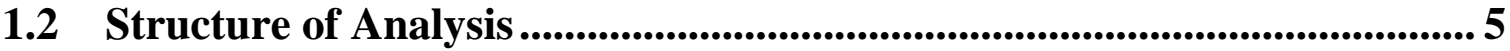

2 CHARACTERISTICS OF LEVERAGED BUYOUTS................................................... 8

2.1 Introductory Remarks .......................................................................... 8

2.2 Private Equity and Leveraged Buyouts........................................................ 8

2.3 Capital Structure .......................................................................................... 9

2.3.1 Theoretical Considerations ........................................................ 11

2.3.2 Empirical Description ........................................................... 14

2.3.3 Equity Parties ............................................................................ 18

2.3.4 Debt Parties.............................................................................. 23

2.4 Research Model............................................................................................. 25

3 THEORETICAL FRAMEWORK......................................................................... 27

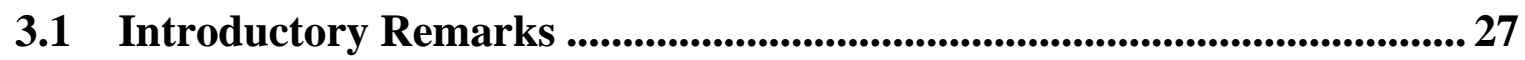

3.2 The Conflict View - Agency Theory............................................................. 27

3.2.1 Agency Conflict between Debt and Equity Holders ....................... 27

3.2.1.1 Asset Substitution ...................................................... 30

3.2.1.2 Underinvestment...................................................... 34

3.2.1.3 Claim Dilution ...................................................... 36

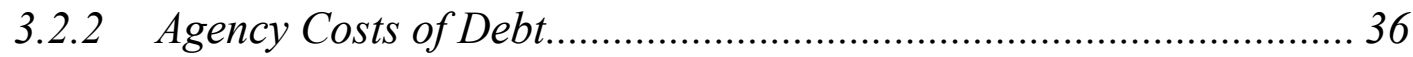

3.2.3 Agency Theory of Covenants .................................................... 37

3.3 The Control View - Financial Contracting Theory .................................. 40

3.3.1 Contractual Incompleteness ..................................................... 40

3.3.2 The Aghion-Bolton Model .................................................... 42

3.3.3 The Rajan-Winton Model ........................................................ 55

3.3.4 Additional Functions of Financial Covenants.............................. 60

3.3.5 Excursus: Signaling Theory of Financial Covenants..................... 60

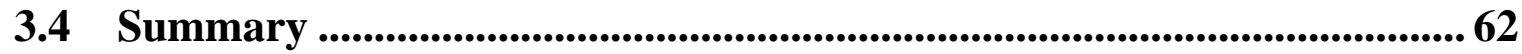

4 CLASSIFICATION AND TYPES OF COVENANTS ......................................................... 64 


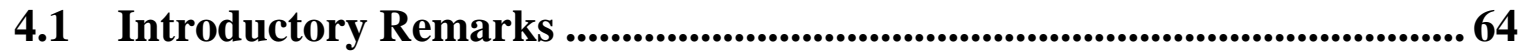

4.2 The Conflict View - Action-restricting Covenants....................................... 64

4.2.1 Covenants limiting Asset Substitution …………………………........... 65

4.2.2 Covenants limiting Underinvestment ………………………......... 66

4.2.3 Covenants limiting Claim Dilution.................................................. 68

4.3 The Control View - Financial Covenants ...................................................... 69

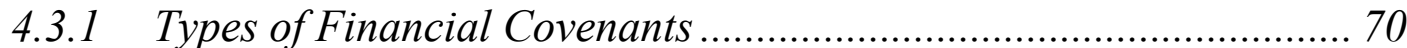

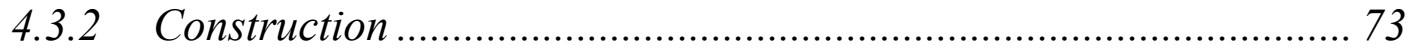

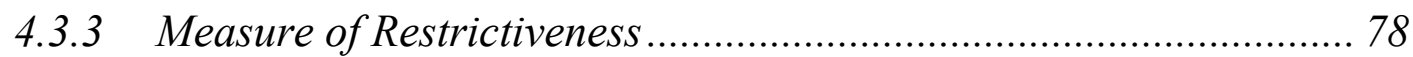

4.3.4 Effectiveness of Financial Covenants............................................. 81

4.4 Covenants in Leveraged Buyouts ............................................................ 82

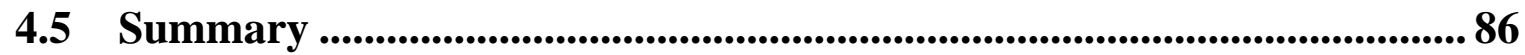

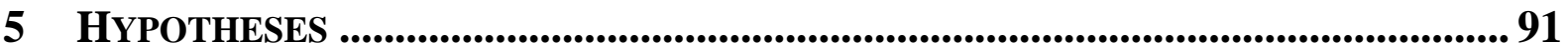

5.1 Introductory Remarks ................................................................................ 91

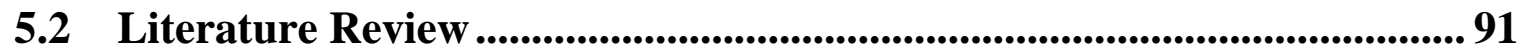

5.3 Hypotheses Development ..........................................................................97

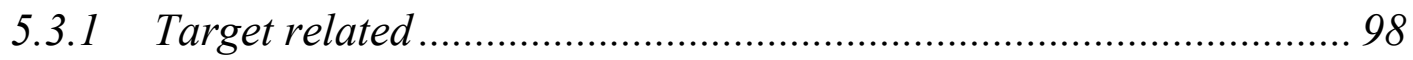

5.3.1.1 Firm Size …………………………………….............. 98

5.3.1.2 Growth ....................................................................... 100

5.3.1.3 Profitability .................................................................... 102

5.3.1.4 Firm Risk .................................................................... 102

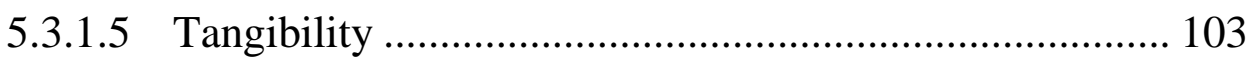

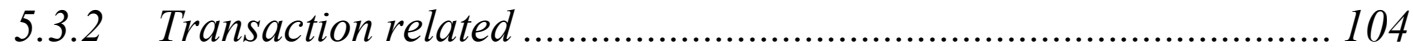

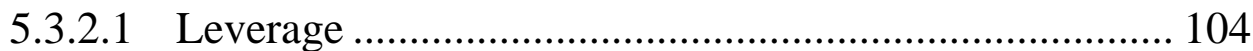

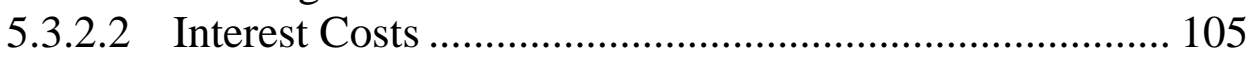

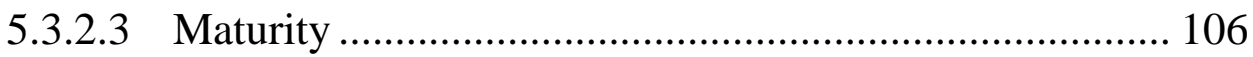

5.3.2.4 Share of Bank Debt ...................................................... 107

5.3.2.5 Creditor Rights Dilution ................................................. 108

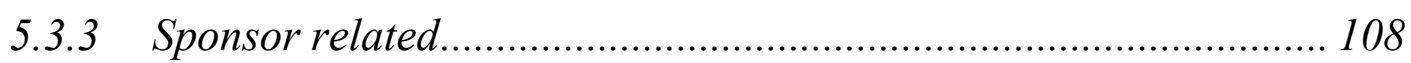

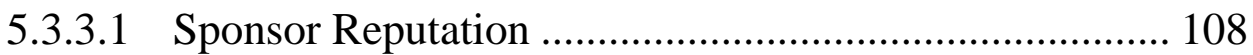

5.3.3.2 Banking Relationship ................................................... 110

5.3.4 Lead Arranger related ............................................................. 113

5.3.4.1 Organization ................................................................ 113

5.3.4.2 Final Hold ......................................................................... 113

5.3.5 Macroeconomic related ............................................................. 116 
5.4 Summary ........................................................................................................... 117

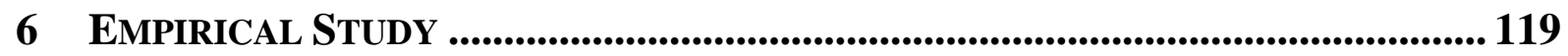

6.1 Introductory Remarks .............................................................................. 119

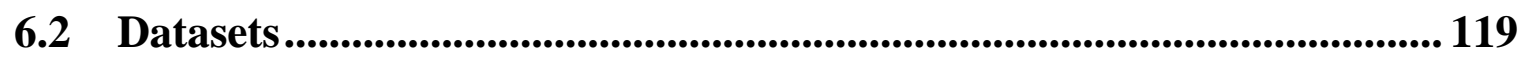

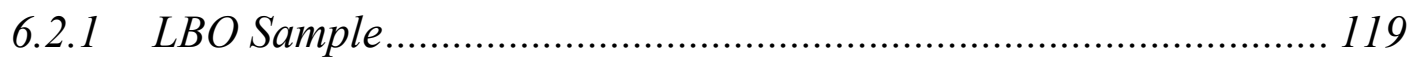

6.2.2 Benchmark Sample .............................................................. 131

6.3 Financial Covenants in Sponsored versus Non-sponsored Loans.......... 133

6.3.1 Types and Combinations of Financial Covenants........................ 133

6.3.2 Financial Covenant Thresholds ................................................. 141

6.4 Descriptive Statistics............................................................................................. 144

6.4.1 Covenant Restrictiveness............................................................ 144

6.4.2 Financial Covenant Pecking Order .............................................. 149

6.4.3 Explanatory Variables.......................................................... 152

6.4.3.1 Target related ............................................................... 152

6.4.3.2 Transaction related ....................................................... 155

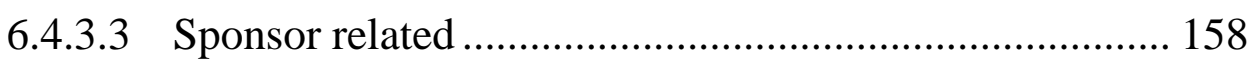

6.4.3.4 Lead Arranger related...................................................... 162

6.4.3.5 Macroeconomic related ................................................... 163

6.5 Determinants of Financial Covenant Restrictiveness .............................. 163

6.5.1 Difference in Means .............................................................. 163

6.5.2 Multiple Regression Analysis ...................................................... 165

6.5.2.1 Target related................................................................ 169

6.5.2.2 Transaction related ..................................................... 171

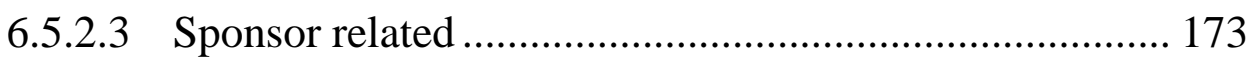

6.5.2.4 Lead Arranger related................................................... 175

6.5.2.5 Macroeconomic related .................................................. 175

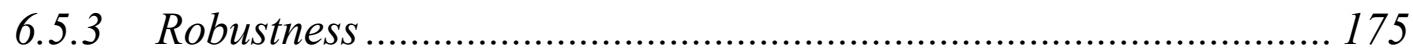

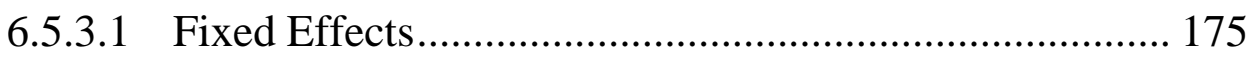

6.5.3.2 EBITDA Definition.......................................................... 176

6.5.3.3 Endogeneity of Headroom and Creditor Rights Dilution177

6.5.3.4 Endogeneity of Leverage and Financial Covenants ....... 180

6.5.3.5 Accounting Manipulation................................................. 181

6.5.3.6 Analysis on Pecking Order of Financial Covenants....... 182

6.6 Summary of Hypotheses Testing.................................................................... 186

6.7 Limitations of the Analysis .............................................................................. 188 


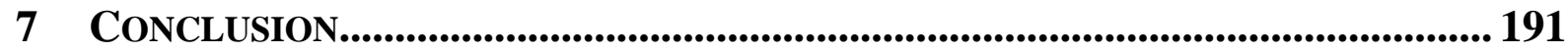

7.1 Summary of Results........................................................................................... 191

7.2 Implications for Research ................................................................ 196

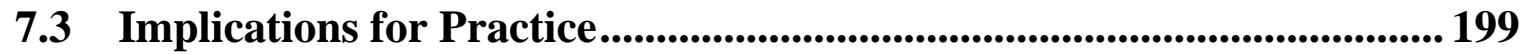




\section{LIST OF FIGURES}

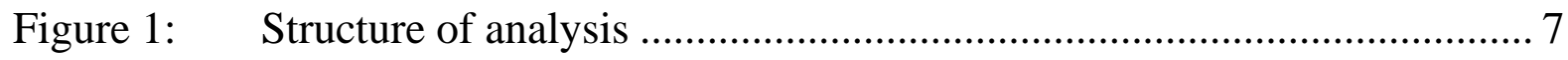

Figure 2: Classification of private equity and buyouts ............................................ 9

Figure 3: Involved parties in a typical LBO..................................................... 10

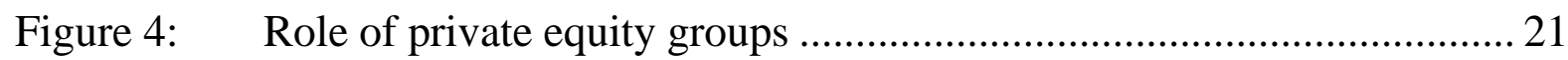

Figure 5: Principal agent relationships in LBOs .................................................. 26

Figure 6: Neoclassical cost of capital with risky debt............................................ 28

Figure 7: $\quad$ Payoff characteristics of equity and debt claims .................................... 31

Figure 8: $\quad$ Agency cost functions for different levels of outside financing............. 34

Figure 9: Technological characteristics of project timeline................................... 43

Figure 10: Overview of different signals obtained by the investor.......................... 56

Figure 11: Exemplary excerpt of financial covenants in a credit agreement........... 74

Figure 12: Conceptional covenant construction................................................... 76

Figure 13: Systematization of covenants in credit agreements ............................... 87

Figure 14: Covenants in public, private, corporate and LBO debt .......................... 89

Figure 15: Determinant categories of financial covenant restrictiveness ................ 98

Figure 16: Minimum D/EBITDA headroom....................................................... 152 


\section{LIST OF TABLES}

Table 1: $\quad$ Typical LBO financing structure and characteristics ........................... 15

Table 2: $\quad$ Types of financial covenants in private credit agreements ..................... 72

Table 3: Financial covenants in a credit agreement.......................................... 77

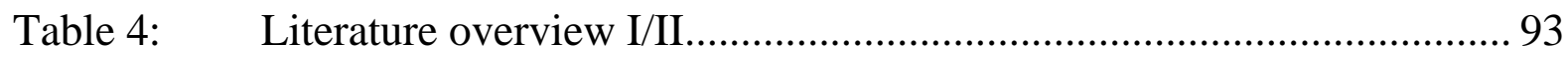

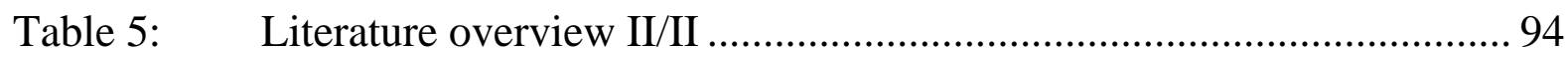

Table 6: Hypotheses on the restrictiveness of financial covenants .................... 118

Table 7: $\quad$ Sample coverage and benchmarking .................................................. 123

Table 8: $\quad$ Size, pricing and capital structure of the sample over time................... 126

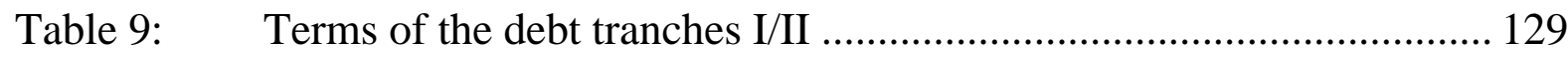

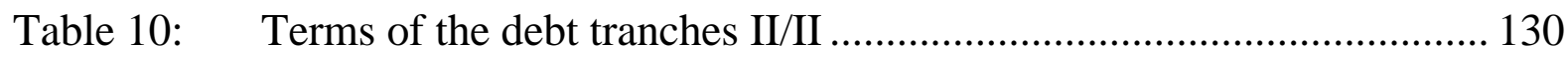

Table 11: Characteristics of sponsored and non-sponsored loans ......................... 133

Table 12: Covenants in sponsored and non-sponsored loans (term loans) I/II.... 135

Table 13: Covenants in sponsored and non-sponsored loans (term loans) II/II .. 136

Table 14: Conditional probabilities of covenant inclusion ..................................... 137

Table 15: Covenant combinations in sponsored and non-sponsored loans ......... 138

Table 16: Covenants in sponsored and non-sponsored loans (matched term

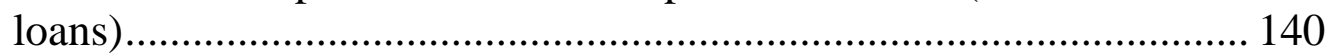

Table 17: Covenant thresholds of sponsored and non-sponsored loans I/II ........ 142

Table 18: Covenant thresholds of sponsored and non-sponsored loans II/II....... 143

Table 19: Covenant thresholds over time ............................................................ 147

Table 20: Covenant headrooms over time …………......................................... 148

Table 20: Headroom comparison of the typical LBO covenants ......................... 151

Table 21: Descriptive statistics for target related variables.................................. 154

Table 22: Descriptive statistics for transaction related variables .......................... 156

Table 23: Composition of the creditor rights dilution index over time ................ 158

Table 24: Descriptive statistics for sponsor related variables................................ 159

Table 25: Descriptive statistics for lead arranger related variables ....................... 162 
Table 26: Descriptive statistics for macroeconomic related variables ................. 163

Table 27: Mean comparison test of D/EBITDA covenant restrictiveness .......... 165

Table 28: Determinants of D/EBITDA headroom I/II....................................... 167

Table 29: $\quad$ Determinants of the D/EBITDA headroom II/II ................................... 168

Table 30: Endogeneity of D/EBITDA headroom and creditor rights dilution .... 179

Table 31: Determinants of the CashFlowCoverage headroom............................. 185

Table 32: Summary of hypothesis testing........................................................... 187

Table 33: Beta coefficients of regressions on the determinants of D/EBITDA headroom ......................................................................................... 201 


\section{List OF ABbREViAtions}

ATC

bps

BVK

CAPM

Capex

CDO

Cf.

CLO

CMBOR

E

EBITDA

EURIBOR

EV

FISD

FCF

GHM

GP

HLT

HR

I

IFRS

IPO

KKR

LBO
Agency theory of covenants

Basis points

Bundesverband Deutscher Kapitalbeteiligungsgesellschaften

Capital asset pricing model

Capital expenditures

Collateralized debt obligation

Confer

Collateralized loan obligation

Centre for Management Buy-Out Research

Equity

Earnings before interest, tax, depreciation, and amortization

European Interbank Offered Rate

Enterprise value

Fixed Investment Securities Database

Free cash flow

Grossman-Hart-Moore approach

General partner

Highly leveraged transaction

Headroom

Interest

International Financial Reporting Standards

Initial public offering

Kohlberg Kravis \& Roberts

Leveraged buyout 
LMA

LP

LPC

M\&A

MBO

Newco

NPV

P2P

PE

PEF

PE group

PIK

PIPE

S\&P

SIC

TLa

TLb

TVE

US

US-GAAP

VC

VIF
Loan Market Association

Limited partner

Loan Pricing Corporation

Mergers \& acquisitions

Management buyout

New company

Net present value

Public-to-private

Private equity

Private equity funds

Private equity group

Payment-in-kind

Private-investments-in-public-equity

Standard \& Poors

Standard industry classification

Term loan A

Term loan B

Thomson Venture Economics

United States (of America)

United States Generally Accepted Accounting

Principles

Venture capital

Variance inflation factors 


\section{Introduction}

\subsection{Relevance and Objectives}

In his seminal paper 'The eclipse of the public corporation', JENSEN (1989) foresaw that private equity owned businesses would become the dominant organizational form in the business world. His conclusion was based on superior corporate governance of private equity backed firms as opposed to public corporations. Particularly, he argued, leveraged buyouts (LBOs) impose a more efficient capital structure, better incentivize management and concentrate ownership with active investors. This prediction did not fulfill in the near future as the LBO market slowed down considerably during the early 1990s. KAPLAN (1997) concluded that public corporations adopted the typical private equity governance mechanisms such as more efficient capital structures, more active ownership and improved incentive structures, compensating the competitive disadvantages of corporate governance structures in the 1980s.

However, the private equity industry has again grown tremendously in the past decade, in terms of value, number of transactions, and its geographic reach. STRÖMBERG (2008) estimates the total aggregated global value of firms acquired by private equity since 1970 at \$3.6 trillion, of which the substantial part (\$2.7 trillion) was transacted in the period from 2001 to $2007 .{ }^{1}$ It is estimated that private equity deals constituted $20 \%$ of the global mergers \& acquisition (M\&A) market in 2006, up from 3\% in $2000 .^{2}$ Private equity expanded from a US phenomenon to a global organizational form. The European private equity market even grew larger than its US counterpart: The relative European global market share in terms of number increased from $38.8 \%$ in the period 1970 to 2000 to $49.9 \%$ in the period 2001 to $2007 .{ }^{3}$ In 2008 the credit crisis evaporated the debt financing for LBOs globally and slowed down the fund raising of private equity groups (PE groups). Still, private equity groups had around \$1.0 trillion in 2009 to

\footnotetext{
${ }^{1}$ Cf. Strömberg (2008), p. 4.

${ }^{2}$ Cf. Axelson, et al. (2010), p. 1.

${ }^{3}$ Cf. Strömberg (2008), p. 16.
} 
invest during the next years indicating the persistent economic importance of private equity. 4

Given the relevance of the private equity industry, it is essential to understand the economic dynamics in private equity transactions. Academic discussion particularly addresses two fundamental questions in this area.

First, in comparison to peer companies, do private equity investors create value for their portfolio companies? Current academic research suggests that private equity creates superior performance on company level; however, after accounting for related fees and carried interest, fund level performance is reduced to or to below capital market returns. ${ }^{5}$

Second, what measures do private equity firms apply to create value in their portfolio companies? Research shows that private equity firms apply governance (I), operational (II), and financial (III) engineering to their portfolio companies, creating economic value. ${ }^{6}$ In terms of governance mechanisms (I), private equity brings in new management members, creates stronger incentives for management, and monitors the buyout company actively and efficiently. ${ }^{7}$ In terms of operational engineering (II), private equity investors increase productivity per employee, reduce capital expenditures improve the innovation process, however the effect on employment remains ambiguous and evidence is heterogeneous. ${ }^{8}$ In terms of financial engineering (III), private equity investors, being corporate finance experts, structure LBOs in a way that maximizes

4 Cf. Prequin press release $30^{\text {th }}$ July 2009, see http://www.preqin.com/docs/press/PE\%20returns\%20down,\%20dry\%20powder\%20high,\%20comp limentary\%20benchmarks\%20launched.pdf

5 For deal level analysis see for example Ljungqvist/Richardson (2003), Nikoskelainen/Wright (2005), Guo/Hotchkiss/Song (2010), Acharya/Hahn/Kehoe (2010), Achleitner, et al. (2010). For fund level analysis see Kaplan/Schoar (2005), Gottschalg/Phalippou (2009), Diller/Kaserer (2009), Driessen/Phalippou/Tse-Chun (2009).

6 Cf. Kaplan/Strömberg (2009), p10f.

7 See for example Gertner/Kaplan (1996), Nikoskelainen/Wright (2005), Acharya/Hahn/Kehoe (2010).

8 See for example Lerner/Sorensen/Strömberg (2008), Steven, et al. (2009), Acharya/Hahn/Kehoe (2010), and Lutz/Achleitner (2009) for a survey on private equity and employment. 
shareholder wealth and reduces financing costs. ${ }^{9}$ However, academic research regarding the capital structure of LBOs is still premature and the existing studies primarily focus on leverage and interest costs. Certain important elements of corporate finance such as the characteristics of debt contracts have been largely disregarded in academia.

Private equity groups finance LBOs with a mixture of equity and debt. The equity component is primarily provided by funds managed by the private equity group. The debt component is typically provided in the form of a syndicated loan that is provided by banks and institutional investors to an acquisition vehicle that is 'sponsored' by the PE group. These syndicated loans contain financial covenants that require the borrower - in this context the buyout company - to maintain a threshold level of certain financial ratios. For example, a typical financial covenant, particularly used in LBOs, is a covenant limiting the maximum ratio of the debt to earnings before interest, tax, depreciation, and amortization (D/EBITDA). Each quarter the bank compares the realized D/EBITDA ratio with the allowable D/EBITDA threshold. If the buyout company fails to maintain the D/EBITDA threshold, the loan is in technical default providing the creditor with the option to terminate the loan. However, in most cases of covenant violation the creditor does not call the loan but renegotiates the contract terms resulting in potential limitations of capital expenditures, higher interest costs, waiver fees or more restrictive covenants. ${ }^{10}$ Hence, financial covenants are an integral element of the credit agreement and their restrictiveness is of considerable value for lenders.

The LBO boom from 2005 to mid 2007, with its increased LBO activity and elevated debt levels $^{11}$, in combination with the subsequent 2008/09 severe recession, endangered many buyout firms to violate their financial covenants and face technical default. Not surprisingly, financial covenants in LBOs received increasing attention in

9 See for example Jensen (1986), Axelson, et al. (2010), Demiroglu/James (2010b), Ivashina/Kovner (2010).

${ }^{10}$ See for example Chen/Wei (1993), Sweeney (1994), Beneish/Press (1995), Dichev/Skinner (2002), Chava/Roberts (2008).

${ }^{11}$ Cf. Kaplan/Strömberg (2009), p. 8. 
the media during this period. ${ }^{12}$ PricewaterhouseCoopers (2010) reports that $75 \%$ of the private equity respondents in their survey had to deal with financial covenant breaches of their portfolio companies or were otherwise required to enter renegotiations with financing banks in 2009. ${ }^{13}$

Interestingly, little is still known about the determinants of restrictiveness of financial covenants in LBOs. The research setting in LBOs seems particularly interesting: First, LBOs concentrate ownership and control creating an interesting setting for capital structure decisions which are less distorted by agency conflicts between managers and owners as the capital structure is negotiation between the private equity group and the bank with little involvement of management. ${ }^{14}$ Second, the negotiations about the capital structure in LBOs without already existing equity or debt holders and their associated claims provides a clear view on the influence of shareholders and debt holders on financial covenants. Third, LBOs constitute a setting with intense conflicts of interest between equity and debt holders given the significant amount of leverage in these transactions and the incentive structure for private equity managers.

Insights from LBO structures might be important for broader corporate finance research as buyouts are executed by knowledgeable professionals, i.e. the private equity group professionals, who utilize sophisticated financial structures to maximize shareholder wealth. ${ }^{15}$ However, the scarce data availability ${ }^{16}$ and the limited quality of da$\mathrm{ta}^{17}$ - even in the United States - have been impeding academic research on financial covenants in LBOs. This thesis aims to reduce this gap in the body of knowledge, answering the following two primary research questions:

12 For instance see the NY Times article 'Analysts will be watching loan covenants in 2009', by Natalie Harrison and Jane Baird, November 302008.

${ }^{13}$ See http://www.pwc.de/fileserver/RepositoryItem/Pr Equity Trend Report 2010.pdf?itemId= 13602751 Last visited on $30^{\text {th }}$ of September 2010.

${ }^{14}$ Additionally, managers typically own part of the business reducing potential conflicts of interest.

15 Cf. Axelson, et al. (2010), p. 1.

${ }^{16}$ As already noted by Gretchen Morgenson, 'Why the Secrecy About Financial Covenants?' NY Times, October 12, 2003.

17 Cf. Demiroglu/James (2010b) obtains only the number of financial covenants and Ivashina/Kovner (2010) limit their analysis on the covenant threshold. 
- How does the covenant menu in terms of individual covenant types and combinations differ in sponsored compared to non-sponsored loans?

- What are the determinants of financial covenant restrictiveness in LBOs?

The first question will be addressed mainly in an empirical manner, comparing a proprietary dataset of LBOs with datasets of traditional corporate loans. In order to answer the second question, theoretical arguments are combined with existing empirical findings on covenants to formulate hypotheses. These hypotheses will then be tested in an empirical analysis using the proprietary dataset of LBOs.

\subsection{Structure of Analysis}

This dissertation contains seven chapters. The structure and contents of the chapters are illustrated in Figure 1. After giving an introduction to the research questions in Chapter 1, the thesis presents essential characteristics of leveraged buyouts (LBOs) in Chapter 2. Following the introductory remarks in Chapter 2.1, Chapter 2.2 classifies LBOs in the broader category of private equity. Chapter 2.3 introduces the characteristics of the LBO capital structure, i.e. explains theoretical differences between LBOs and public companies, describes the typical capital structure and lays out the roles of the involved parties. Chapter 2.4 reduces the complex LBO structure to a simple model of equity and debt holders that serves as the basis for the theoretical framework.

Chapter 3 builds the theoretical framework that provides the economic rationale for the utilization of covenants in credit agreements. Chapter 3.1 explains the dichotomous concept, conflict and control view, of the following theoretical framework. Chapter 3.2 explains the agency conflict between debt and equity holders (conflict view) leading to agency costs that in turn might be reduced by writing actionrestricting covenants in credit agreements. Chapter 3.3 extends the conflict view using financial contracting theory (control view) to explain the economic rationale for financial covenants. Chapter 3.4 gives a summary of the theoretical framework.

The dichotomous theoretical framework is then used in chapter 4 to explain and classify different types of action-restricting and financial covenants, also describing the covenant setting in LBOs. Chapter 4.1 conceptualizes the analysis of the different types of 
covenants. Chapter 4.2 defines and classifies action-restricting covenants according to their theoretically motivated conflict between equity and debt holders (conflict view). Chapter 4.3 gives an overview of types of financial covenants, explains how financial covenants are constructed and how to measure their restrictiveness, as well as discusses the effectiveness of financial covenants. Chapter 4.4 investigates the setting of financial covenants in LBOs, i.e. sponsored loans, as opposed to public debt and nonsponsored loans. Chapter 4.5 summarizes the findings of this chapter.

Chapter 5 formulates hypothesis on the relationships between potential determinants and the restrictiveness of financial covenants. After Chapter 5.1 gives an overview of the conceptual structure, Chapter 5.2 presents the existing streams of covenant literature and classifies the most important studies. Chapter 5.3 uses theoretical arguments and empirical findings to derive hypotheses on potential determinants of financial covenant restrictiveness in leveraged buyouts. Chapter 5.4 summarizes the hypotheses.

Chapter 6 presents the empirical evidence of the study. Chapter 6.1 gives an overview of the following empirical analysis. Chapter 6.2 describes the LBO dataset and the benchmark sample. Chapter 6.3 compares the financial covenants used in LBO loans, i.e. sponsored loans, to financial covenants in traditional corporate loans, i.e. nonsponsored loans. Chapter 6.4 presents descriptive statistics for financial covenants, gives empirical evidence on a hierarchy of financial covenants and describes the characteristics of explanatory variables. Chapter 6.5 uses univariate and regression analysis to empirically test the hypotheses and checks the results for robustness. Chapter 6.6 summarizes the results of the hypotheses testing. Chapter 6.7 further tests the pecking order argument using multiple regression analysis. Chapter 6.8 discusses some limitations of the analysis.

Chapter 7 concludes by summing up the results (chapter 7.1) and giving implications for research (chapter 7.2) and practice (chapter 7.3). 


\begin{tabular}{|c|c|c|c|}
\hline \multicolumn{4}{|l|}{ 1. INTRODUCTION } \\
\hline \multicolumn{2}{|c|}{ Relevance and Objectives } & \multicolumn{2}{|c|}{ Structure of Analysis } \\
\hline \multicolumn{4}{|c|}{ 2. CHARACTERISTICS OF LEVERAGED BUYOUTS } \\
\hline $\begin{array}{l}\text { Private Equity and } \\
\text { Leveraged Buyouts } \\
\end{array}$ & \multicolumn{2}{|c|}{ Capital Structure } & Research Model \\
\hline \multicolumn{4}{|c|}{ 3. THEORETICAL FRAMEWORK } \\
\hline \multicolumn{2}{|c|}{ The Conflict View - Agency Theory } & \multicolumn{2}{|c|}{ The Control View - Financial Contracting } \\
\hline \multicolumn{4}{|c|}{ 4. CLASSIFICATION AND TYPES OF COVENANTS } \\
\hline \multicolumn{2}{|c|}{$\begin{array}{c}\text { The Conflict View - } \\
\text { Action-restricting Covenants }\end{array}$} & \multicolumn{2}{|c|}{$\begin{array}{l}\text { The Control View - } \\
\text { FinancialCovenants }\end{array}$} \\
\hline \multicolumn{4}{|c|}{ Covenants in Leveraged Buyouts } \\
\hline \multicolumn{4}{|l|}{ 5. HYPOTHESES } \\
\hline \multicolumn{2}{|c|}{ Literature Review } & \multicolumn{2}{|c|}{ Hypotheses Development } \\
\hline \multicolumn{4}{|l|}{ 6. EMPIRICAL STUDY } \\
\hline \multicolumn{2}{|c|}{ Datasets } & \multicolumn{2}{|c|}{$\begin{array}{c}\text { FinancialCovenants in Sponsored and Non- } \\
\text { sponsored Loans }\end{array}$} \\
\hline \multicolumn{2}{|c|}{ Descriptive Statistics } & \multicolumn{2}{|c|}{$\begin{array}{c}\text { Determinants of Financial Covenant } \\
\text { Restrictiveness }\end{array}$} \\
\hline \multicolumn{2}{|c|}{ Summary of Hypotheses Testing } & \multicolumn{2}{|c|}{ Limitations of the Analysis } \\
\hline \multicolumn{4}{|l|}{ 7. CONCLUSION } \\
\hline Summary of Results & \multicolumn{2}{|c|}{ Implications for Research } & Implications for Practice \\
\hline
\end{tabular}

Figure 1: $\quad$ Structure of analysis

Source: Author 


\section{Characteristics of Leveraged Buyouts}

\subsection{Introductory Remarks}

The following sections present the characteristics of leveraged buyouts (LBOs). The first section classifies LBOs in the broader category of private equity (PE). The second section introduces some theoretical considerations why the capital structure in LBOs should be different from public companies. The third section lays out the structure of LBOs, i.e. explains the capital structure and the associated equity and debt parties. Fourth, the complex LBO structure is reduced to a simple institutional model including two parties - equity holders and debt holders -, which is used to explain the economic foundations of covenants.

\subsection{Private Equity and Leveraged Buyouts}

KASERER et al. (2007) define private equity in the broader sense as equity investments in private companies - in contrast to investments in public companies. ${ }^{18}$ Private equity in the broader sense can then be classified (see Figure 2) into equity investments in early stage companies ('venture capital') and later stage companies, i.e. established, mature companies ('private equity in the narrower sense'). Later stage investments comprise minority investments and majority investments, referring to the share of common equity. ${ }^{19}$

Generally, one or more private equity groups (PE groups) in the narrower sense target the majority of common equity to gain control over the established business. In this context a buyout is defined as the acquisition of a controlling stake of funds managed by a PE group in an established company from its owners for a limited time, financed through a combination of equity and debt. ${ }^{20}$

${ }^{18}$ Cf. Kaserer, et al. (2007), p. 14.

${ }^{19}$ Cf. Kaserer, et al. (2007), p. 15. For an exploratory study on minority investments see Achleitner/Schraml/Tappeiner (2008).

${ }^{20}$ Cf. Berg/Gottschalg (2005), p. 9. 
Buyouts can be categorized according to the reason for the sale (like succession buyout, going private buyout etc.) or to the type of acquirer (management buyout, institutional buyout etc.). ${ }^{21}$ However, whenever a large amount of debt is utilized - although the exact level of debt is not defined - to finance the acquisition of the target company the buyout is labeled 'leveraged buyout'. 22

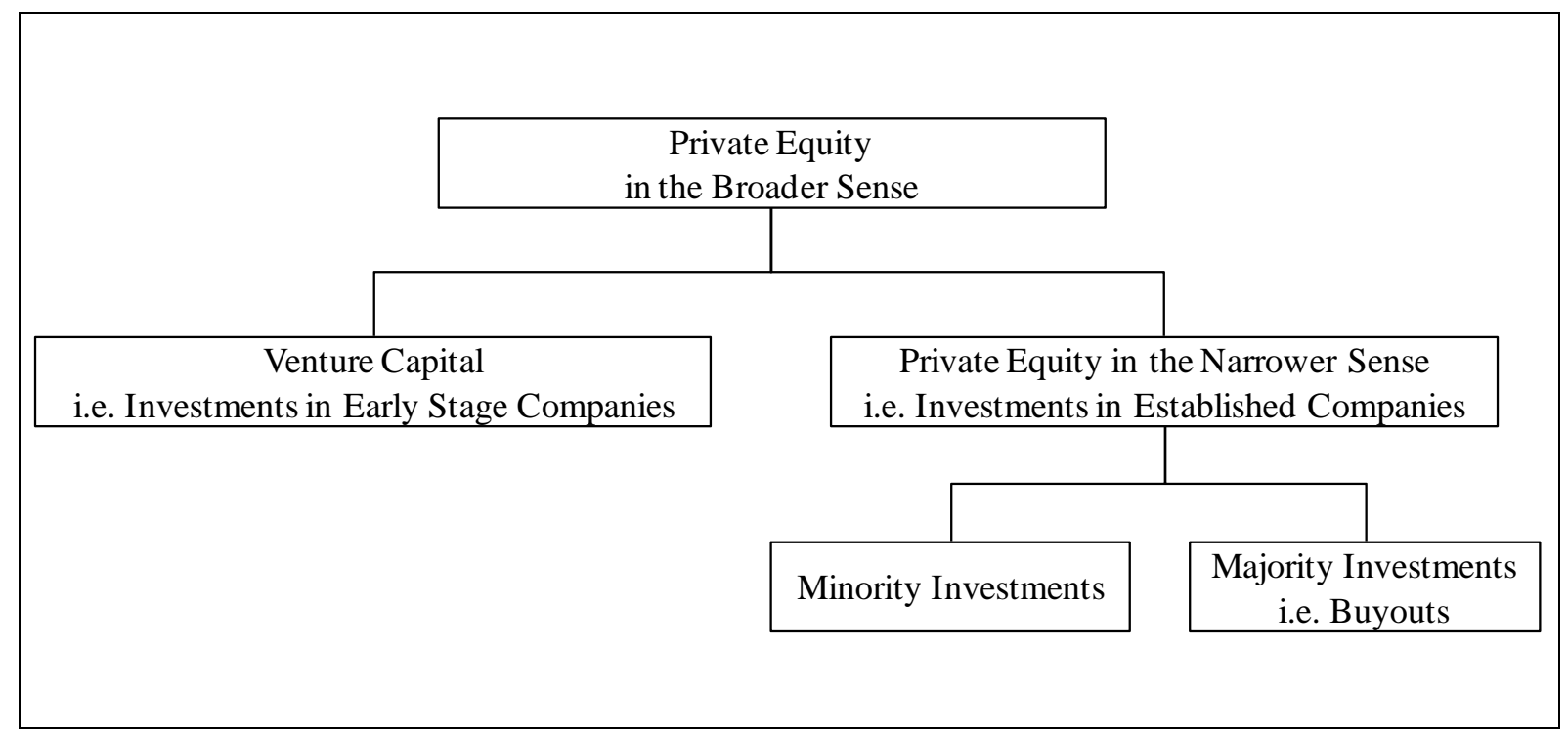

Figure 2: $\quad$ Classification of private equity and buyouts

Source: $\quad$ KASERER et al. (2007), p. 14

This thesis follows the classifications and definitions just outlined, but also includes investments in public equity, i.e. public-to-private (P2P) transactions and privateinvestments-in-public-equity (PIPE). This definition is in line with the one formulated by KAPLAN/STRÖMBERG (2009). ${ }^{23}$

\subsection{Capital Structure}

In a typical leveraged buyout (LBO) a private equity group (PE group) will form a new company ('newco') specifically for the purpose to acquire a controlling stake in the target company (for a graphical illustration of the LBO structure see Figure 3).

${ }^{21}$ For a detailed categorization of buyouts see Klöckner (2009), p. 25 or Geidner (2009), p. 7f.

${ }^{22}$ Cf. Kaserer, et al. (2007), p. 15.

${ }^{23}$ This definition is also in line with the private equity definition in the report ,The Global Economic Impact of Private Equity Report 2008', which was compiled for the World Economic Forum 2008. Cf. Lerner/Gurung (2008), Executive Summary, p. vii. 


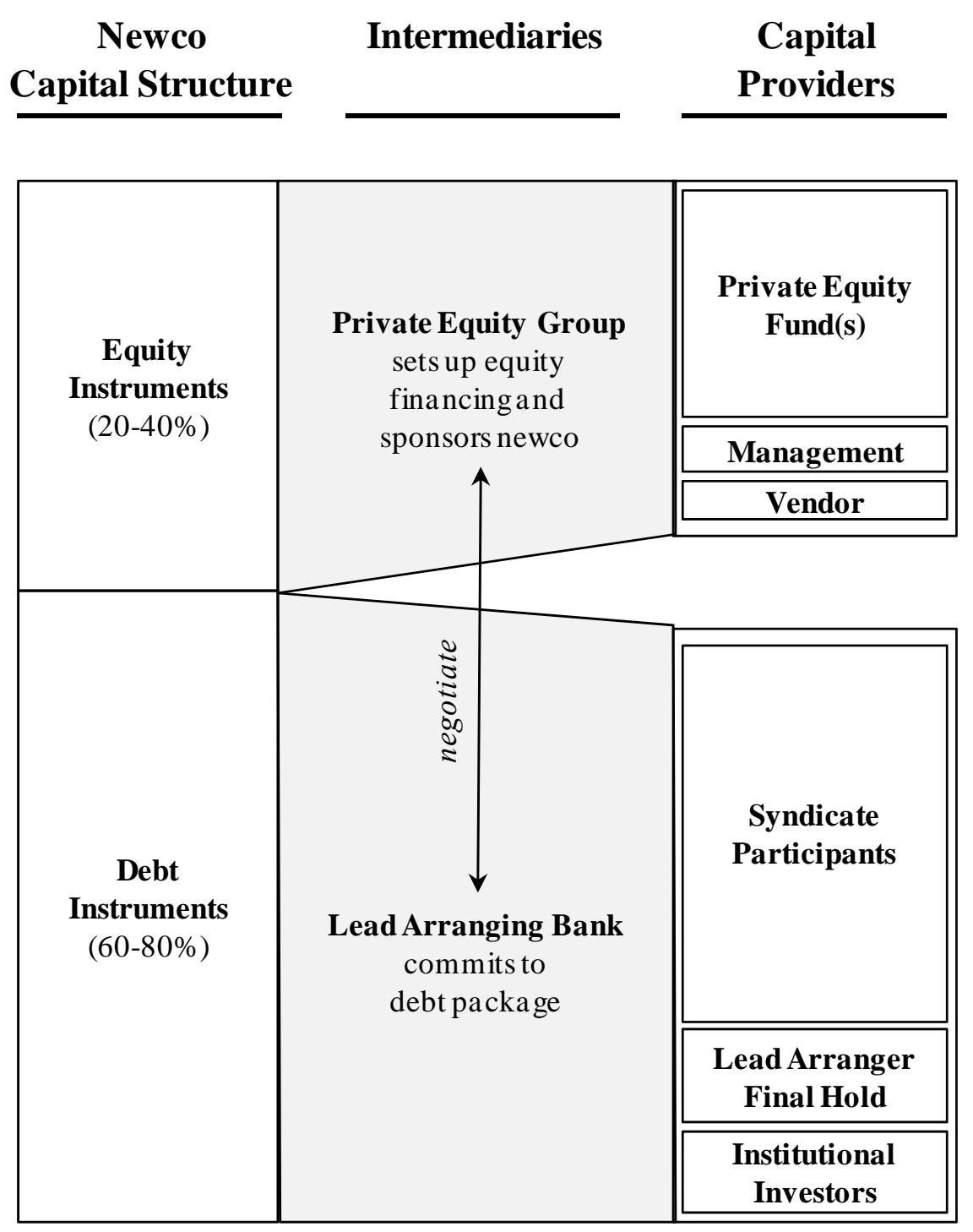

Figure 3: $\quad$ Involved parties in a typical LBO Source: Author

The newco is credible because it is 'sponsored' by one or more PE groups that interact frequently with capital markets. To finance the acquisition, this newco is funded with equity and debt. The main equity component is typically provided by a fund, managed by a PE group. ${ }^{24}$ However, usually the buyout management contributes to the equity as well and sometimes the vendor provides funds, too.

${ }^{24}$ Note that this constitutes the simple case. A leveraged buyout may include several funds from one PEG or even more PEGs. 
Besides the equity component, debt financing is essential to LBOs. Private equity groups primarily utilize debt financing to increase the expected return on equity, i.e. to create a leverage effect. ${ }^{25}$ In order to obtain debt financing for the capitalization of the newco, the PE group presents the potential buyout to banks. If the bank commits to fund the newco with debt, it becomes the lead arranger of the transaction. In case the transaction is unsuccessful, the newco is unwound and the debt component lapses.

The lead arranger typically does not provide the entire debt financing but syndicates parts of the debt to other, so called participating, banks or institutional investors. ${ }^{26}$ Typical institutional investors are collateralized debt obligation (CDO) funds, hedge funds, mutual funds and insurance companies. ${ }^{27}$ The following sections explain the capital structure in more detail and present the role of the involved parties with a primary focus on the intermediaries in Figure 3, i.e. the PE group and the lead arranger.

\subsubsection{Theoretical Considerations}

Before going into the empirical details of observed capital structures in LBOs, it is essential to explain basic theoretic considerations on the capital structure in LBOs. As there is a comprehensive literature on the capital structure of public firms, it is crucial to explain arguments why the capital structure in LBOs, including the utilization of covenants, should be any different from public firms. ${ }^{28}$

AXELSON/STRÖMBERG/WEISBACH (2009) base their capital structure theory of LBOs on the conflict of interest between the General Partners (GPs), i.e. fund managers, and Limited Partners (LPs), i.e. fund investors. ${ }^{29}$ Their model evaluates the capital structure of LBOs. They consider the combination of two sources: ex ante financing defined as the funds provided by LPs at the beginning of the fund and ex post financ-

${ }^{25}$ For a fundamental description of the leverage effect see Modigliani/Miller (1958).

${ }^{26}$ This overview is an aggregation of Schell (2006), §1.04, Axelson, et al. (2010), p. 7f., Kaplan/ Strömberg (2009), p. 124f.

${ }^{27}$ For a good survey on institutional investors in the leveraged loan market see Ivashina/Sun (2009).

${ }^{28}$ Cf. Axelson, et al. (2010) p. 10-14 for an overview.

${ }^{29}$ The description for GP and LP is simplified in this section to avoid distraction. For further details on the role of GPs and LPs see section 2.3.3. 
ing, provided in the form of debt for respective LBOs. ${ }^{30}$ The optimal capital structure is defined as the capital structure that maximizes the value of aggregated investments by minimizing the value of negative net present value (NPV) investments while reducing ignored good investments. Their model shows that it is optimal to use a mix of ex ante and ex post financing. The share of the ex ante capital in the transaction (the equity component) preserves the GP's incentives to avoid bad deals in good times ${ }^{31}$ and the ex post component (debt) prevents the GP to undertake bad investments in bad times. ${ }^{32}$ However, at a more general level, the incentive structure of private equity funds provides the GP with an option-like stake in the fund, which induces them to lever each deal as much as possible. In this context, leverage also increases the pricing of LBOs as the pricing is set by the GP who also determines leverage. In public markets, even if the manager of a public firm has similar incentives to lever the firm, the price is set by independent investors. ${ }^{33}$

Additionally, AXELSON et al. (2010) argue that bankruptcy costs are lower for private equity backed companies than for public companies. They name two reasons for this hypothesis. First, if an LBO is in financial distress the sponsor can inject equity from its funds into the company whereas public companies have to issue new potentially dilutive equity (see also section 4.3.4). ${ }^{34}$ The second argument leads back to the long-term relationship between the PE group and the bank or the debt market. This relationship should facilitate any renegotiation, which in turn reduces distress costs. ${ }^{35}$ Reduced distress costs should consequently lead to potentially higher optimal leverage. $^{36}$

${ }^{30}$ Cf. Axelson/Strömberg/Weisbach (2009), p. 1553.

${ }^{31}$ The rationale behind this effect is that the compensation of the GP depends upon the performance of the entire fund and not single investments. Since bad deals will contaminate his stake in good deals the GP has less of incentives to invest in bad deals. Cf. Axelson/Strömberg/Weisbach (2009), p. 1551.

${ }^{32}$ Cf. Axelson/Strömberg/Weisbach (2009), p. 1551.

33 Cf. Axelson, et al. (2010), p. 14.

${ }^{34}$ Cf. Axelson, et al. (2010), p. 11.

${ }^{35}$ Cf. Gertner/Scharfstein (1991).

${ }^{36}$ Cf. Axelson, et al. (2010), p. 11. 
Another argument for differences in the optimal capital structure for LBO firms and public companies is the value of the tax shield. In public firms the total tax effect includes corporate tax rates as well as personal tax rates. ${ }^{37}$ Since the personal tax rates of the shareholders are unobservable for the firm, MILLER (1977) concludes that it is difficult to apply the tradeoff theory of MYERS (1984), in which the capital structure is chosen where marginal tax advantages and marginal bankruptcy costs are identical. By contrast, since the typical investors in private equity funds, e.g. pension funds, are tax-exempt, the tax shield effect should be more observable in LBOs. ${ }^{38}$

Additionally, LIU (2009) looks at the conflict of interest between PE groups and managers in private equity-backed companies. His model shows that a capital structure including long-term debt is a mechanism to reduce agency problems. ${ }^{39}$ The different capital structure of public firms and LBOs can be explained by different time horizons and concentrated ownership. First, the PE group has full control rights on the capital structure, whereas public firm shareholders face many constraints in making capital structure decisions. Second, in contrast to the public firm, the finite ownership of private equity does not allow a repeated game or long-term relationship with management. ${ }^{40}$

Finally, COTTER/PECK (2001) argue that private equity groups play an important role in the governance of the post-LBO firm. Private equity owned businesses benefit from the consequent monitoring and from the financial expertise of the GP. This constellation equips the buyout company with a higher debt capacity.

Overall, these theories predict that leverage in private equity backed companies is higher than in public companies. The study of AXELSON et al. (2010) provides first comprehensive empirical evidence confirming this notion.

\footnotetext{
37 Cf. Miller (1977), p. 267.

${ }^{38}$ For a more detailed description see Axelson, et al. (2010), p. 10-11.

39 In his model, agency problems cannot be solved by compensation. Cf. Liu (2009), p.4.

${ }^{40}$ Cf. Liu (2009), p. 18-19.
} 


\subsubsection{Empirical Description}

Having explained the theoretical deviations between capital structures in public firms and LBOs, this section describes the typically observed detailed capital structure in LBOs, starting with the equity component followed by the debt part. Private Equity Groups structure LBOs using a wide variety of financial instruments that range across several levels of seniority from common equity to senior debt. Table 1 presents the detailed funding structure of a typical LBO. Additionally, Table 1 attributes the most important characteristics for the utilized financing instruments, specifies the usual lender base and gives a practical example. In general, LBOs are financed with equity sourced by the PE group (20-40\% of capital) and several senior and subordinated debt tranches, typically provided in the form of syndicated loans underwritten by lead arranging banks $(60-80 \%) .{ }^{41}$

The equity component in LBOs is primarily provided through funds managed by the PE group. The PE group structures the equity component in a way that optimizes equity returns and management incentives. A widely utilized instrument is the shareholder loan that is constructed to be tax deductible and to allocate common equity of 5 to $20 \%$ to management, although management actually only contributes a small fraction of the overall equity component. ${ }^{42}$ The ratio between the value of the common shares and the actual injected capital of management is known as 'envy ratio' and typically ranges from four to six. This construction leads to increased performance incentives for the LBO management as it receives a large payoff for a successful LBO. ${ }^{43}$

\footnotetext{
${ }^{41}$ Cf. Axelson, et al. (2010), Demiroglu/James (2010b), Ivashina/Kovner (2010).

${ }^{42}$ Cf. Eilers/Koffka/Mackensen (2009), p. 317, Jonsson (2005), p. 51, Mittendorfer (2007), p. 31.

${ }^{43}$ Cf. Mittendorfer (2007), p. 31.
} 


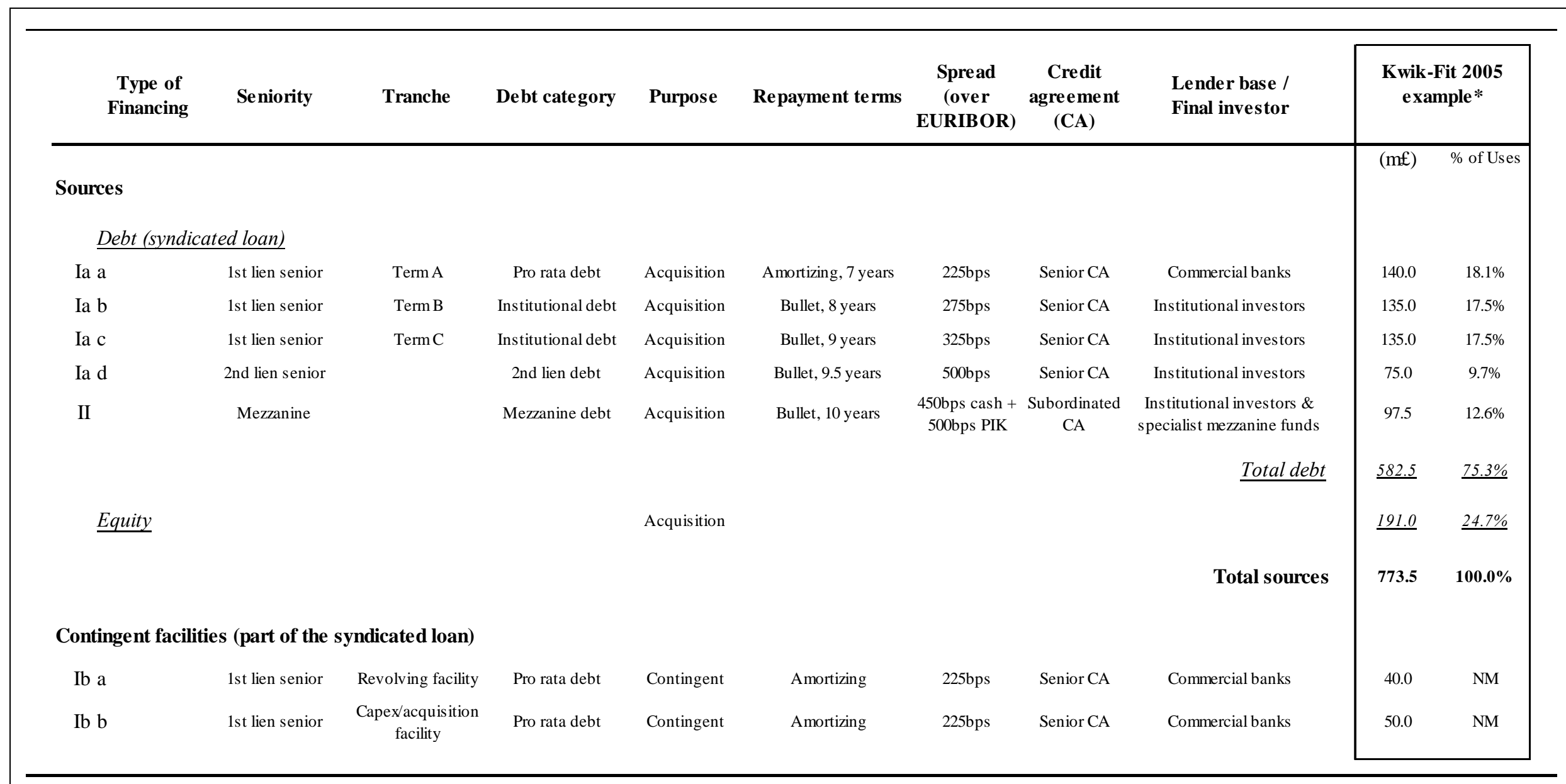

* Note: Kwik-Fit is a UK based tyre and exhaust fitting company. In 2005, PAI bought Kwik-Fit from CVC.

Table 1: $\quad$ Typical LBO financing structure and characteristics

Source: $\quad$ Author, Kwik-Fit example taken from AXELSON et al. (2010), p. 33 
Another possible source of equity are funds provided by the vendor of the company. This form of financing is primarily used when buyer and seller have different price expectations. Although the economic nature of this financing form is similar to preferred shares, it is misleadingly labeled vendor 'loan' since their interest component might be tax deductible for the buyout company. Vendor loans reduce the financing volumes the PE group has to provide and are typically used when credit markets are restrictive with LBO financing, as was the case during the credit crisis. ${ }^{44}$

While the PE group originates the equity component, debt financing is typically arranged by banks in the form of syndicated loans. In contrast to bonds, syndicated loans can be arranged within a few days, which is essential to complete an LBO successfully. ${ }^{45}$

In general, LBO debt structures are very homogenous and non-trivial in terms of debt layers and debt instruments. Syndicated loans used for LBO financing typically include senior (see number I in Table 1) and subordinated debt (II) tranches. Senior debt can be divided into several different tranches. The lion's share of the tranches is used by the PE group to pay the acquisition price (Ia) and the remainder can be drawn of the LBO company during the holding period (so called contingent facilities (Ib) like revolving or capex facilities). A typical LBO contains three different term loans, Term A (Iaa), Term B (Iab) and Term C (Iac) loans. While Term A is amortizing, Term B and $\mathrm{C}$ pay interest-only with a final bullet principal repayment. The Term A tranche usually matures after seven years while Term B and C tranches repay after eight and nine years respectively. Spreads are usually homogeneous in the cross section and based on EURIBOR, with Term A typically paying 250 bps, Term B and C 300 bps and 350 bps, respectively. ${ }^{46}$

\footnotetext{
${ }^{44}$ Cf. Mittendorfer (2007), p. 138.

${ }^{45}$ Cf. Axelson, et al. (2010), p. 8.

46 Sometimes misleading, Term loan 'A' (or TLa) may also describe amortizing loans, while Term loan 'B' (or TLb) may stand for bullet payments, which typically have the tranche letters B and C. Cf. Miller/Chew (2009), p. 13-14.
} 
Besides these financing instruments that are consumed for the acquisition of the target company, the senior credit agreement contains contingent facilities which are provided by banks and paid out when the borrower draws down the funds. The typical sort of contingent facility is the revolving credit line (Iba) which is undrawn at the time of transaction but may be drawn to finance working capital needs or other short-term cash needs. The contingency may also depend on certain capital expenditures (Ibb) or pre-specified acquisitions. The terms and conditions for the contingent facilities typically mirror the terms of the Term A tranche. This conformity is due to the identical lender base of Term A loans and the contingent facilities (together also known as 'pro rata debt') that are funded by commercial banks, whereas Term B and C is also called 'institutional' senior debt because the investor base primarily consists of institutional investors. $^{47}$

The high demand for LBO loans and the strive for higher returns for senior loans during the boom periods in the 1980ies and from 2004 to 2007, induced PE groups and lead arrangers to structure loans, which are included in the senior credit agreement but junior to the aforementioned tranches. This form of senior loan is known as $2^{\text {nd }}$ lien tranche (Iad) because they are junior to the $1^{\text {st }}$ lien tranche of the senior credit agreement. In Europe, $2^{\text {nd }}$ lien tranches typically pay spreads of 500-700 bps over EURIBOR and are structured as bullet payment after nine to ten years. European $2^{\text {nd }}$ lien tranches are protected by the financial covenants in the senior credit agreement, i.e. exhibit the same covenant protection as $1^{\text {st }}$ lien tranches. ${ }^{48}$ The investors of $2^{\text {nd }}$ lien loans are typical institutional debt purchasers such as mezzanine funds and hedge funds.

Besides senior debt, PE groups utilize subordinated debt (II), which is also included in the syndicated loan package. Subordinated debt typically takes the form of mezzanine that is primarily funded by institutional investors. Mezzanine debt usually exhibits longer maturities than term loans and pays back at the end of maturity. Interest costs

\footnotetext{
${ }^{47}$ Cf. Rosenbaum/Pearl (2009), p. 183, Polenberg/Lukatsky/Gupte (2010), p. 14.

48 This is different in the US where 2nd lien loans also typically have less restrictive covenant packages in which headrooms are looser. Cf. Polenberg/Lukatsky/Gupte (2010), p. 15.
} 
are higher and more heterogeneous than term loan spreads, paying 1000-1250 bps over EURIBOR. In the past it was also quite common to include bridge financing that is later substituted by a public bond. However, bonds were replaced by the increasing demand for leveraged loans from institutional investors through collateralized loan obligations (CLOs) or in its direct form. ${ }^{49}$

\subsubsection{Equity Parties}

Private Equity investments are typically made by funds that are commonly organized as limited partnerships. These Private Equity Funds (PEFs) are raised to accumulate capital in order to make equity investments in portfolio companies from limited partners (LPs) and are managed by general partners (GPs), the so called Private Equity Groups (PE groups). ${ }^{50}$ The LPs, mainly large institutional investors or wealthy individuals, as well as the GPs have capital commitments ${ }^{51}$ for specific amounts and are obligated to make capital contributions as needed for investments during the investment period of the fund. ${ }^{52}$

The lifetime of PEFs depends on the structure of the fund which can be either open end or closed end. Open end funds, so called evergreen funds, do not have an explicit lifetime and cash flows from investments are not paid out but reinvested. By contrast, the more prominent type fund, the closed end fund, has a fixed lifetime of around ten years. ${ }^{53}$ Regarding distributions of closed end funds, cash flows from investments are paid out to fund investors.

Given the potential conflicts between LPs and GPs the economics of the partnership agreements are essential to align interests between investors and fund managers, main-

49 The information above was derived and summarized from Kaplan/Stein (1993), Axelson, et al. (2010), Demiroglu/James (2010b), Achleitner/Braun/Tappeiner (2010), Brinkhuis/De Maeseneire (2009), Ivashina/Kovner (2010), Kühn (2006) and Eilers/Koffka/Mackensen (2009).

${ }^{50}$ Cf. Sahlman (1990), p. 487, Fenn/Liang/Prowse (1995), p.1, Axelson/Strömberg/Weisbach (2009), p. 1550.

51 Metrick/Yasuda (2010) define committed capital as the sum of capital to be invested, lifetime fees plus establishment cost. Establishment cost is related to set up costs of the fund.

${ }^{52}$ Cf. Schell (2006), § 1.04[2], Metrick/Yasuda (2010), p. 2.

${ }^{53}$ Cf. Müller (2008), p. 18, Metrick/Yasuda (2010), p. 2. 
ly through explicit performance incentives. The partnership agreement defines the expected payments to GPs typically consisting of a fixed component, i.e. the management fee and a variable component, primarily the carried interest. METRICK/YASUDA (2010) mention that transaction and monitoring fees are potential additional variable components. Given their relative lower importance, this thesis does not explicitly explain these variable components. ${ }^{54}$

The management fee is meant to cover the actual cost of managing the fund and typically ranges form 1.5 to 2.5\%. METRICK/YASUDA (2010) report that out of 144 funds raised between 1992-2006, 74 charged less than 2.0\% management fee, 59 charged $2.0 \%$ and 11 charged more than $2.0 \%$. To arrive at the fee amount that has to be paid to GPs, the management fee is multiplied with a certain fee base. During the investment period, the fee base is equal to committed capital but changes to invested capital after the investment period. METRICK/YASUDA (2010) show that 84\% of funds change their fee basis after the investment period. ${ }^{55}$ The management fee is independent from the performance and may induce the PE group to exert lower effort during the investment stage.

To ensure that the GP exerts the maximum effort, the partnership structure typically includes a considerable variable component: the carried interest. The carried interest, or also 'carry', is the GP's share of the limited partnership's return, i.e. the combined profits of the pooled investments. The calculation of the carried interest based on fund level returns replaced the calculation on a deal-by-deal basis. The reason for the replacement of the deal-by-deal approach is that it creates incentives for the GP to maximize the risk of individual investments. ${ }^{56}$ Profit sharing arrangements for GPs are nonlinear and concave in relation to the fund performance: LPs first receive all their cash flows until they reach a specific level. Typically, the committed capital compounded with a 'preferred return' or 'hurdle rate', then the GP receives $100 \%$ of profits until he 'catches up' to LPs; beyond this point GPs receive the carried interest and

\footnotetext{
${ }^{54}$ For further details see Metrick/Yasuda (2010), p. 25.

55 For a similar European study see Feinendegen/Schmidt/Wahrenburg (2003).

${ }^{56}$ Cf. Axelson/Strömberg/Weisbach (2009), p. 1570.
} 
LPs the remainder. ${ }^{57}$ The typical hurdle rate is $8.0 \%$ and the carried interest is usually set to $20.0 \%{ }^{58}$ The carried interest is therefore an option-like claim on the fund profits and may consequently lead to an excessive risk taking by GPs, especially during the later phase of the fund which is also known as 'end-period gaming'.59

One mitigating factor of the conflict of interest between GPs and LPs is that deals are done with a combination of the 'ex ante' financing, i.e. fund commitments, and 'ex post' financing, i.e. debt that is raised for each deal separately in LBOs. This debt financing is an external control mechanism for the state of the industry and the quality of the investment, reducing the possibility of excessive risk taking by GPs. ${ }^{60}$ AXELSON/STRÖMBERG/WEISBACH (2009) also construct a theoretical model that shows the optimality of the 'real world' incentive structure of private equity funds.

Having explained the structure and explicit economic terms of Private Equity Funds, it is essential to understand the role and incentives of Private Equity Groups that manage these funds as General Partners.

Figure 4 illustrates the role of the PE group. This includes fundraising (I), investing of the fund capital in the equity of portfolio companies (II), and divesting the investments, distributing the resulting cash flows to investors (III). ${ }^{61}$ This thesis focuses on number II, i.e. the investment activities of the PE group. This function encompasses three stages, namely selecting the portfolio companies (IIa), structuring the transaction (IIb) and initiating value adding activities in portfolio companies (IIc) ${ }^{62}$ Again, given the focus of this thesis on financial structures and financial covenants in LBOs, this section concentrates on the role of the PE group during the second stage, i.e. the financial structuring of the transaction (IIb).

${ }^{57}$ Cf. Axelson/Strömberg/Weisbach (2009), p. 1571.

${ }^{58}$ Cf. Metrick/Yasuda (2010), table II, Gompers/Lerner (1999), p.15, For a European study with similar results see Feinendegen/Schmidt/Wahrenburg (2003), p. 1178.

${ }^{59}$ Cf. Axelson/Strömberg/Weisbach (2009), p. 1573.

${ }^{60}$ Cf. Axelson/Strömberg/Weisbach (2009), 1549 f.

${ }^{61}$ For a detailed description see Gompers/Lerner (2004).

62 This classification is similar to Wright/Robbie (1998) but extends the last step from monitoring to execute value adding activities. 


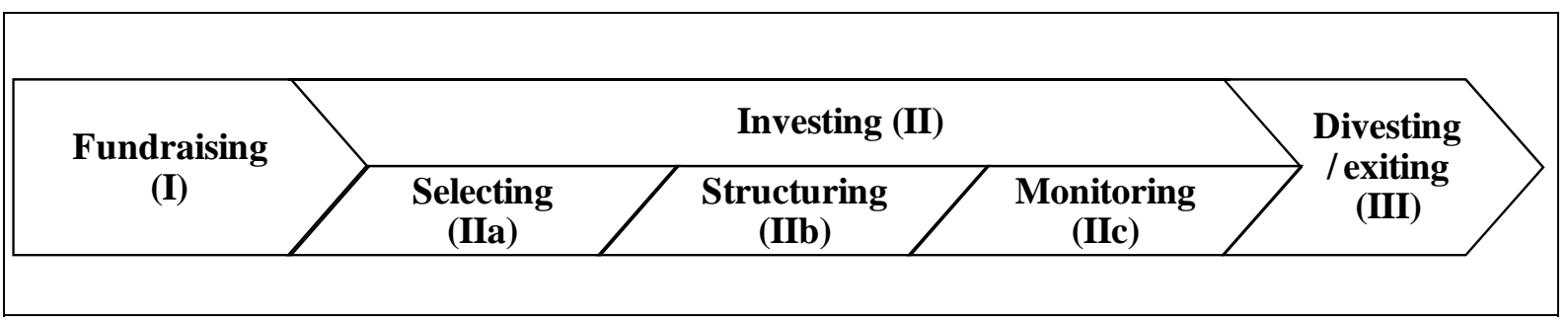

Figure 4: $\quad$ Role of private equity groups

Source: $\quad$ ACHLEITNER (2002), p. 748

Having selected a company to acquire, the PE group is responsible to capitalize the newco (see Figure 3) with sufficient funds, i.e. equity and debt, to pay the price for the shares of the target company and redeem pre-LBO debt holders. The final bid for a target company typically includes an equity commitment letter from the Private Equity Group and debt commitment letter from the lead arranger. ${ }^{63}$

On the equity side, the PE group allocates funds from its PEFs and/or syndicates a share to funds managed by other PE groups. Deals including more than one PE group are called 'club deals'. In order to increase the purchase price and the equity share, PE groups often - especially during times of restricted debt supply - try to convince vendors to grant loans to the LBO company. ${ }^{64}$ Depending on the personal wealth of the company's management, $\mathrm{PE}$ groups typically demand that management co-invests a certain amount to align incentives with the PE group (see also 2.3.1 and Figure 3). ${ }^{65}$

On the debt side, the PE group is responsible to attract banks to underwrite the debt commitment. ${ }^{66}$ After the PE group has identified a target company, it sends preliminary information to potential lead arranging banks. Based on the provided information, lead arrangers decide on whether to submit a term sheet to the PE group. The term sheet typically includes rough estimates of the debt package including interest margins, debt package, maturity as well as types and restrictiveness of financial covenants.

\footnotetext{
63 Cf. Dennis/Mullineaux (2000), p. 408.

${ }^{64}$ Cf. Eilers/Koffka/Mackensen (2009), p. 300.

65 See also section 2.3.1.

${ }^{66}$ For a detailed description of the debt providing perspective see 2.3.4.
} 
Based on due diligence results ${ }^{67}$ the PE group negotiates the financing case, i.e. the financial projections for the buyout company, with the lead arranging bank. The financing case serves as the fundament to determine the explicit debt package and instruments. ${ }^{68}$ Finally, the PE group negotiates the detailed terms and conditions of the credit agreement with the lead arranging bank.

In terms of incentives, PE groups have explicit stimuli in the form of carried interest but are also incentivized by implicit measures, related to the ability to raise future funds. This implicit incentive of PE groups is known as the reputational conservation effect. The incentives to conserve the benefits derived from reputation reduce conflicts of interests between LPs (i) but also lenders (ii). Regarding the relationship between PE groups and LPs (i), CHUNG et al. (2010) formalize the implicit incentive for GPs based on the LP's assessment of the GP's performance and behavior to allocate capital to the PE group's next fund. They find that the implicit incentives from future fundraising are about the same as explicit incentives from the current fund's carried interest. $^{69}$

Regarding the relationship between PE groups and lenders (ii), PE groups benefit from their reputation as reputation facilitates ex post deal-by-deal debt financing. DIAMOND (1989) shows how borrower reputation mitigates conflicts of interests between lenders and borrowers. As successful track records lead to better lending terms, borrowers benefit from their good reputation. PE groups that have proven to be overly successful and plan to raise future funds, implying a future debt raising amount of two to three times ${ }^{70}$ the amount of the targeted fund sizes, have considerable incentives to avert excessively risky projects.

\footnotetext{
${ }^{67}$ Due diligence efforts aim to critically assess risks for the buyout company and includes financial, legal, tax and commercial components. For a more detailed description see Eilers/Koffka/Mackensen (2009), p. 34f.

${ }^{68}$ For a detailed description of the process see 4.3.2.

${ }^{69}$ Cf. Chung, et al. (2010), p. 9 and p. 23.

${ }^{70}$ Estimate based on $25 \%$ to $33 \%$ equity share.
} 


\subsubsection{Debt Parties}

The debt financing for LBOs is typically provided in the form of syndicated loans and normally include senior as well as subordinated debt tranches. ${ }^{71}$ A syndicated loan is provided to a borrower by a group of financial institutions. Syndicated loans represent a hybrid of private and public debt. ${ }^{72}$ BOOT/THAKOR (2000) describe a syndicated loan as a mixture between 'relationship loans' and 'transaction loans' ${ }^{73}$ Syndicated loans typically contain both structural elements of loan financing: the lead bank screens and monitors the borrower in a relationship-like context; however, these loans also contain elements of a capital-market-like environment as the lead arranging bank sells and/or underwrites a certain share of the loan or the entire loan. ${ }^{74}$ The following paragraph explains the role of the lead arranging bank in the process to originate a syndicated loan for an LBO, a so called leveraged loan.

In a leveraged loan, the PE group submits preliminary information on the lending opportunity to several banks. Banks then submit a term sheet that broadly defines covenants, fees, loan amount and interest rates. Based on the term sheet as well as reputational and relationship aspects, the PE group mandates one or more bank(s) to be the lead arranger(s). The PE group and the lead arranger sign a preliminary loan agreement ('mandate or commitment letter'). ${ }^{75}$ The bank may commit to fund the entire loan package or a portion of it with a promise to use best effort to arrange financing from other lenders. ${ }^{76}$

After signing the commitment letter, the lead arranger - in close collaboration with the PE group - conducts due diligence on the potential buyout company, forms its own view of the company's development, translates these expectations into financial projections, and finally determines the offered debt package and the financial instruments.

\footnotetext{
${ }^{71}$ See also section 2.3.1.

${ }^{72}$ Cf. Dennis/Mullineaux (2000), p. 404.

${ }^{73}$ Cf. Boot and Thakor (2000), p. 685, but also Sufi (2007), p. 641.

${ }^{74}$ Cf. Dennis/Mullineaux (2000), p. 405.

${ }^{75}$ Cf. Sufi (2007), p. 632.

${ }^{76}$ Cf. Dennis/Mullineaux (2000), p. 408.
} 
To attract other financial institutions to join the syndicate, the lead arranger prepares an 'information memorandum', also known as 'bank book', containing important descriptive and financial information regarding the business prospects of the buyout company. ${ }^{77}$ The addressees for pro rata debt, i.e. Term A and contingent facilities, are banks whereas institutional senior loans, $2^{\text {nd }}$ lien and subordinated debt is advertised to institutional investors. ${ }^{78}$ During this process the lead arranger coordinates and drafts all the loan documents (senior and subordinated) in direct negotiation with the PE group.

Syndicate participants may provide comments and suggestions prior to signing but are generally not involved in the negotiations with the PE group. ${ }^{79}$ Once the loan amount is allocated to the syndicate lenders - including the take of the lead arranger, also known as final hold -, the loan agreement is signed by all parties. ${ }^{80}$ After the loan has been provided for the LBO, the lead arranger acts as the 'agent' managing the loan, i.e. acting as the middleman for cash flows between senior and subordinated lenders and borrowers.

The Loan Market Association (LMA), the European trade association for the syndicated loan market, summarizes the functions of the agent as follows ${ }^{81}$ :

- Point of Contact: representing the views of the syndicate towards the borrower

- Monitor: monitoring the compliance of the borrower with the credit terms

- Postman and Record-keeper: borrower gives notice to agent

- Paying agent: agent collects payments from borrower and distributes them to syndicate members

The agent also takes the lead in negotiating waivers and is permitted to declare the default of a loan. To limit the powers of the agent, the loan agreement contains an 'agen-

\footnotetext{
77 Cf. Dennis/Mullineaux (2000), p. 408.

${ }^{78}$ Cf. Demiroglu/James (2010b), p. 307, Polenberg/Lukatsky/Gupte (2010), p. 14f.

${ }^{79}$ Cf. Dennis/Mullineaux (2000), p. 408.

${ }^{80}$ Cf. Sufi (2007), p. 633.

${ }^{81}$ Cf. LMA (2007), p. 3, cf. also Dennis/Mullineaux (2000), p. 408.
} 
cy section' that formulates the conditions for the removal of the agent. Typically, lead arrangers are released from any potential liability to syndicate members except for 'gross negligence or misconduct'. In return for their service, the lead arranger is compensated in form of fees, typically as a percentage of the entire syndicated loan. ${ }^{82}$

\subsection{Research Model}

This section reduces the complex structure of a typical LBO to a basic model that will be used in the theoretical framework to explain the foundations of covenants in general and financial covenants in particular.

In theory, whenever a person or institution (the principal) engages another person or institution (the agent) to perform decision making on behalf of the principal, there exists a principal agent relationship. ${ }^{83}$ The unit of analysis in principal agent relationships is the contract between the principal and the agent. ${ }^{84}$ In an LBO there are two levels of principal agent relationships (see Figure 5).

On the first level relationship, debt holders invest their money in a buyout company but delegate decision making and control rights to equity holders. The equity holders then decide how to allocate the debt amount.

\footnotetext{
${ }^{82}$ Cf. Steffen (2008).

83 Cf. Jensen/Meckling (1976), p. 308.

${ }^{84}$ Cf. Eisenhardt (1989), p. 59.
} 


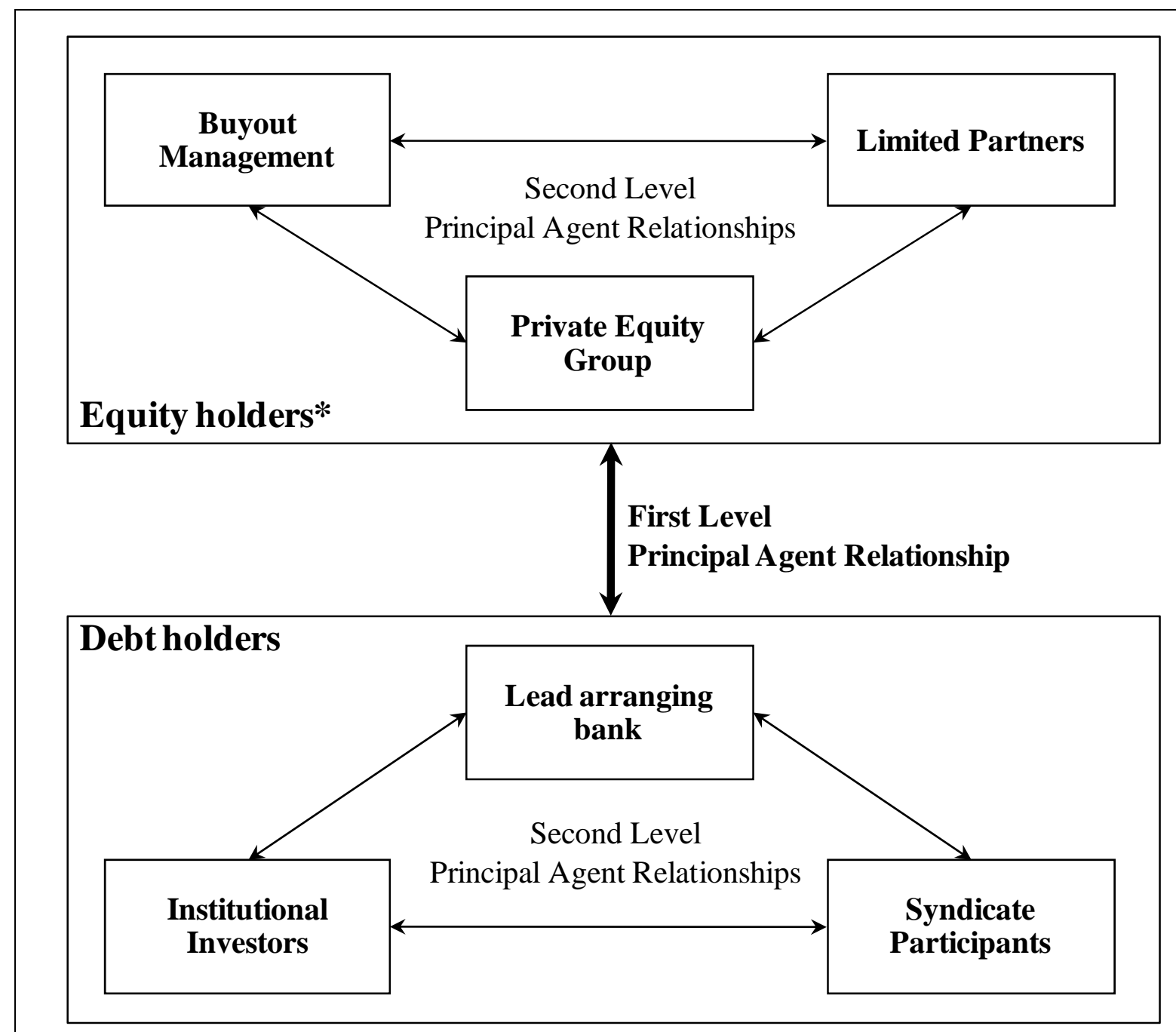

* Note: For reasons of simplicity, parties like e.g. vendors a re excluded from the framework.

Figure 5: $\quad$ Principal agent relationships in LBOs Source: $\quad$ Author

On the second level, i.e. inside the groups of debt and equity holders there are again a number of principal agent relationships. For example in the group of equity holders, the LP commits his money to the PEF which is managed by the PE group which in turn invests the funds in companies and delegates the decision making over the asset to a management team.

As this thesis analyzes the contract between debt and equity holders, the following theoretical framework focuses on the first level principal agent relationship and provides economic rationales for the inclusion of covenants in credit agreements. 


\section{Theoretical Framework}

\subsection{Introductory Remarks}

This section introduces a theoretical dichotomous ${ }^{85}$ taxonomy for the rationale of covenants that is in line with economic considerations following TIROLE (2006) and focuses on the relationship between equity and debt holders. The first economic rationale for covenants, the 'conflict view', has its foundation in the principal agent theory and explains the usage of action-restricting covenants. The second economic rationale for covenants, the 'control view', is based on financial contracting theory ${ }^{86}$ and explains the usage of financial covenants as well as the combination of financial and actionrestricting covenants in credit agreements. Both constructs belong to the capital structure theory of new institutional economics. ${ }^{87}$ The area of new institutional economics is based on following assumptions: methodological individualism (i), individual utility maximization (ii), individual rationality (iii), opportunistic behaviour of individuals (iv), institutional environment (v), and existence of governance structures (vi). ${ }^{88}$

\subsection{The Conflict View - Agency Theory}

\subsubsection{Agency Conflict between Debt and Equity Holders}

MODIGLIANI/MILLER (1958) show that under certain neoclassical assumptions ${ }^{89}$ the choice of the capital structure does not impact the cost of capital of the firm. In a

${ }^{85}$ This classification of covenants is not common in literature. In general the existing literature tends to distinguish between positive and negative covenants. Positive covenants prescribe certain actions the borrower must take. Negative covenants restrict managerial decisions. Since a positive covenant might also be formulated the opposite way thus being classified as a negative covenant, this classification is not meaningful. This line of argument follows Tirole (2006) who gives an example: the positive covenant, maintaining assets in good repair and working order, can be formulated as the prohibition of letting the assets wear and tear, which is a negative covenant. Cf. Tirole (2006), p. 84.

${ }^{86}$ Note that financial contracting also builds upon the theoretical construct of agency theory.

${ }^{87}$ Cf. Rudolph (2006) chapter 5, p. 117-161. The field of new institutional economics comprises the property-rights-theory, the transaction-cost-theory, the principal agent theory, and the theory of incomplete contracts.

${ }^{88}$ Cf. Richter/Furubotn (1999), p. 2-9.

89 The assumptions are: (i) perfect capital market without taxes or transaction costs; (ii) institutions and individuals borrow at the same risk-free rate; (iii) firms finance themselves with risk-free debt 
continuative work, STIGLITZ (1974) demonstrates that the total cost of capital is also independent from the distribution of the firm's risk on equity and debt holders, as shown in Figure 6. If the cost of debt (denoted $k_{C o D}$ ) is not constant but increases after a certain degree of leverage because debt holders share part of the firm's risk, the cost of equity (denoted $k_{C O E}$ ) decreases proportionally because risks are transferred to debt holders. However, the overall cost of total capital (denoted $k_{T C}$ ) remains constant. In this world there would not be any rationale for covenants as the capital structure does not affect the value of the firm.

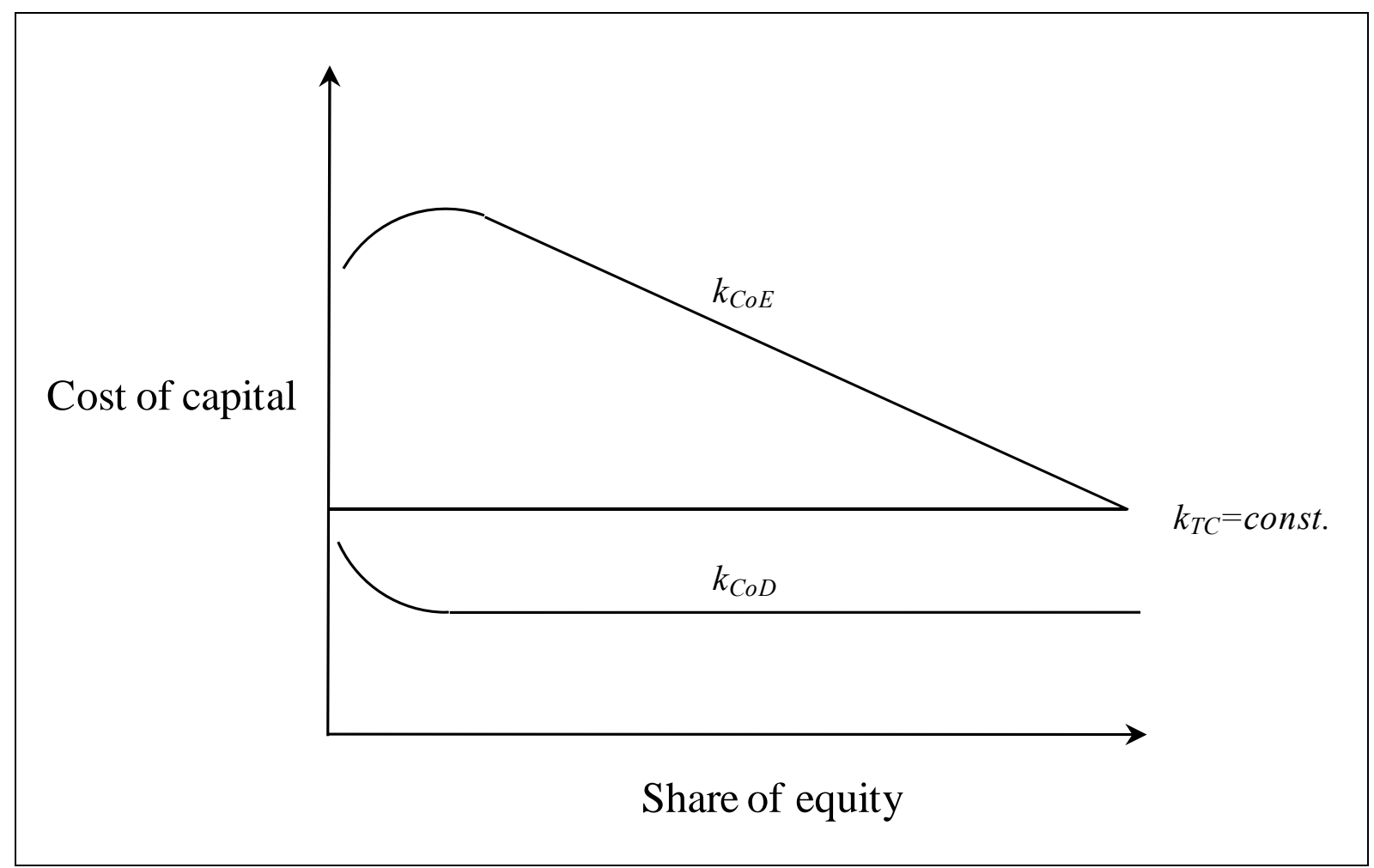

Figure 6: $\quad$ Neoclassical cost of capital with risky debt Source: $\quad$ Author on the basis of RUDOLPH (2006), p. 96

LELAND (1994) analyzed the impact of the inclusion of covenants ${ }^{90}$ on the value of corporate debt and the optimal capital structure. He finds that the value of debt with

and risky equity; (iv) homogenous expectations of market participants regarding the distribution of future cash flows.

${ }^{90}$ Leland (1994) assumes long-term debt with financial covenants, a positive net worth covenant in particular. He notes that this structure is not common in debt agreements but proxies a roll-over process which is common in practice. Cf. Leland (1994), p. 1234. 
covenants (protected debt) may be lower than the value of debt without covenants (unprotected debt) when bankruptcy costs are greater than zero, which is a realistic case. ${ }^{91}$

This follows because bankruptcy, and also the related cost, occurs more frequently when debt includes covenants. Indicatively, this seems irritating as this would imply that covenants do not have an economic rationale. However, LELAND (1994) then moves on to the agency problems between equity and debt holders developed by JENSEN/MECKLING (1976), abandoning the assumption of the new classical view. ${ }^{92}$

Migrating from the neoclassical view of firms as production functions to the new institutional view, firms are seen as institutions that aggregate the individual interests of economic agents who have different stakes in the institution. ${ }^{93}$ In their seminal paper on the effect of capital structure on the firm value, JENSEN/MECKLING (1976) view the firm as a 'legal fiction' that serves as a nexus for contracting relationships. ${ }^{94}$ The firm contains divisible claims on future cash flows of the organization (including those of asset disposal). ${ }^{95}$ These claims are held by individuals (some may be other organizations) which might have conflicting interests. JENSEN/MECKLING (1976) define a principal agent relationship (also known as agency relationship) as a contract, under which a principal delegates some decision making authority to an agent. ${ }^{96}$ Principal and agent are trying to maximize their individual utility, which suggests that the agent will not always act in the best interest of the principal. JENSEN/MECKLING (1976) discuss two agency relationships that might result in conflicts and consequently costs for the firm:

\footnotetext{
${ }^{91}$ Cf. Leland (1994), p. $1235 f$.

92 Cf. Leland (1994), p. $1243 f$.

${ }^{93}$ Cf. Rudolph (2006), p. 119.

94 The work of Jensen/Meckling (1976) mainly builds on property rights literature from Coase (1937) and on agency literature from Ross (1973).

95 Cf. Jensen/Meckling (1976), p. 314.

${ }^{96}$ Cf. Jensen/Meckling (1976), p. 308.
} 
- Agency costs of outside equity ${ }^{97}$ are costs that arise for the firm due to conflicts of interest between outside owners (shareholders as principals) and inside owners (managers as agents).

- Agency costs of debt $t^{98}$ relate to costs that might occur to the firm based on potential conflicts between debt holders and shareholders (or managers acting on behalf the shareholders).

Since covenants in credit agreements are concerned with regulating the relationship between debt holders and shareholders this thesis concentrates on the conflicts related to agency costs of debt. The existence of debt within a firm leads to incentive effects associated with its inherent payoff characteristics. These properties induce the debtor to undertake actions that transfer wealth from creditors to themselves. The seminal works of JENSEN/MECKLING (1976), MYERS (1977) and SMITH/WARNER (1979) show three different incentive effects of shareholders inducing them to take actions that expropriate creditors, i.e. the value of debt is reduced.

\subsubsection{Asset Substitution}

The following section explains why shareholders of leveraged firms are likely to engage in asset substitution, i.e. in actions that increase the risk of the firm, in order to increase their wealth and expropriate debt holders. ${ }^{99}$ Due to the characteristics of the convex equity claim according to BLACK/SCHOLES (1973), the equity holder has incentives to make higher-risk investments. Following BLACK/SCHOLES (1973), owning the equity of a firm is identical to the option to buy the firm paying the face value of debt, i.e. the principal amount, to debt holders at expiration date (see Figure 7). It shows that the value of equity has a limited downside and an unlimited upside.

In this model the value of equity $(S)$ is:

negatively related to the face value of debt $B$, i.e. $\partial_{B} S_{t}<0$,

\footnotetext{
97 Cf. Jensen/Meckling (1976), p. 315-340.

98 Cf. Jensen/Meckling (1976), p. 345-358.

${ }^{99}$ Cf. Jensen/Meckling (1976), p. 345-350.
} 
positively related to the value of the firm $V$, i.e. $\partial_{V} S_{t}>0$,

positively related to the riskless interest rate $r$, i.e. $\partial_{r} S_{t}>0$,

positively related to the time to expiration $T-t$, i.e. $\partial_{T-t} S_{t}>0$,

and positively related to the variance of the return $\sigma$, i.e. $\partial_{\sigma} S_{t}>0$. $^{100}$

Equity \& Debt

Holders' Return

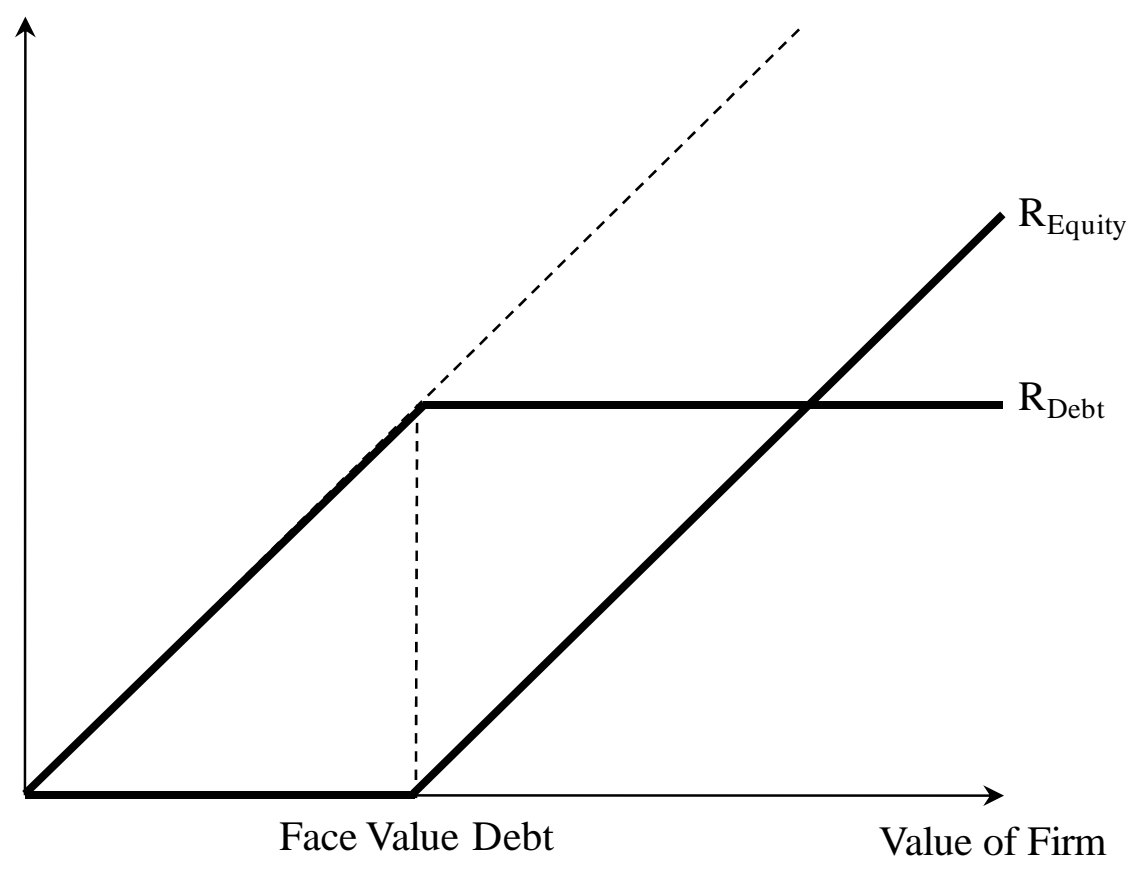

Figure 7: $\quad$ Payoff characteristics of equity and debt claims

Source: $\quad$ Author with reference on the basis of TIROLE (2006), p. XX.

Debt holders enter the contractual relationship expecting the amount lent to be invested in projects of ex ante specified risk. In a contract without any covenants, if shareholders increase their risk behavior ex post ${ }^{101}$, they transfer wealth from the debt holders to themselves. ${ }^{102}$ Based on this conflict between equity and debt holders JEN-

\footnotetext{
${ }^{100}$ Cf. Galai/Masulis (1976), p. 57.

${ }^{101}$ Ex ante and ex post are used in relation to the point in time when the contract was signed.

${ }^{102}$ Cf. Jensen/Meckling (1976), p. 334-337.
} 
SEN/MECKLING (1976) developed an agency theoretic perspective on capital structure. This seminal work will be explained in the following. ${ }^{103}$

A manager-owned firm with a certain value of debt outstanding in a world without taxes is confronted with the decision of two mutually exclusive investment alternatives $I_{1}$ and $I_{2}$. The investments bear identical initial costs and yield random cash flows with payoff profile $\mathrm{E}(\overline{\mathrm{X}})$. However, they show differences in their variances, i.e. $\sigma_{1}^{2}<\sigma_{2}^{2}$. The systematic risk or covariance risk of each distribution is assumed to be identical. If asset prices are determined according to the capital asset pricing model (CAPM), the market values of the payoff distributions are identical and represented by $V$.

If the firm value is fixed, an increase in the value of equity can only be made at the expense of the value of debt. Let $B_{1}$ be the current market value of debt if $I_{1}$ is taken and $B_{2}$ the value of debt if $I_{2}$ is taken. The value of the firm $V$ can be decomposed into the value of its equity $(S)$ and its debt $(B), V=S+B$. Since $V$ is independent of the investment choice and also of the financing decision ${ }^{104}$ the values of debt $B_{j}$ and equity $S_{j}$ can be determined applying the BLACK/SCHOLES (1973) option pricing formula.

The stockholders hold a European call option on the value of the firm with exercise price $X^{*}$ (the face value of debt), exercisable at the expiration time of the bonds $T$. If the value of the firm at that date is larger than the face value of debt, the debt holders will receive $X^{*}$ and the stockholders will receive the remainder $V-X^{*}$. Since the value of a call option rises with the variance of returns because the likelihood that the call-option like claim will be 'in the money' increases, it follows that $S_{1}<S_{2}$ and therefore $B_{1}>B_{2}$. Now, if the owner-manager could issue the bonds for $X^{*}$ making the buyer believe that he will choose investment $I_{1}$, he would receive $B_{1}$. After issuing the debt, his equity value would be $S_{1}$. As $S_{2}$ is greater than $S_{1}$ the owner-manager can increase his wealth by choosing $I_{2}$ and thereby reducing the wealth of the debt holder.

\footnotetext{
${ }^{103}$ This formal description of the asset substitution problem will be continued to explain the agency costs of debt.

${ }^{104}$ Cf. Modigliani/Miller (1958).
} 
JENSEN/MECKLING (1976) continue to show how agency costs (denoted $A$ ) develop with changes of the capital structure. Figure 8 shows the development of agency costs of debt (denoted $A_{B}$ ), agency costs of equity (denoted $A_{S}$ ) and total agency costs (denoted $A_{T}$ ) with changing share of equity (denoted $E$ ) and the amount of outside financing (denoted $K$ ). Agency costs of debt rise with increasing leverage, while agency costs of equity (denoted $A_{S}$ ) decrease. With increasing amount of external financing agency costs of debt as well as agency costs of debt rise. The functional form of the agency costs of debt has a decreasing marginal effect, i.e. an increase of a unit of equity has a larger impact on the agency costs of debt when there is high leverage as when there is low leverage. The outcome of the model is that there is an optimal degree of leverage that minimizes the total agency costs.

Additionally, given the call-option character of the shareholder's claim, his incentives to engage in risk shifting increase with the likelihood of default. ${ }^{105}$ As a firm is approaching a potential bankruptcy, shareholders might risk even more because under capitalization is not borne by shareholders but mostly by debt holders. This effect is also known as 'gamble for resurrection'. ${ }^{106}$

GALAI/MASULIS (1976) formally describe various different situations how shareholders might expropriate debt holders in these cases. By applying the option-pricingmodel they show that acquisitions and divestitures changes in the scale of the firm, conglomerate mergers and spin-offs might impact the value of debt following an action from shareholders. ${ }^{107}$

\footnotetext{
${ }^{105}$ Cf. Malitz (1994), p. 8.

${ }^{106}$ Cf. Rudolph (2008), p. 177.

${ }^{107}$ Cf. Galai/Masulis (1976), p. 62-70.
} 


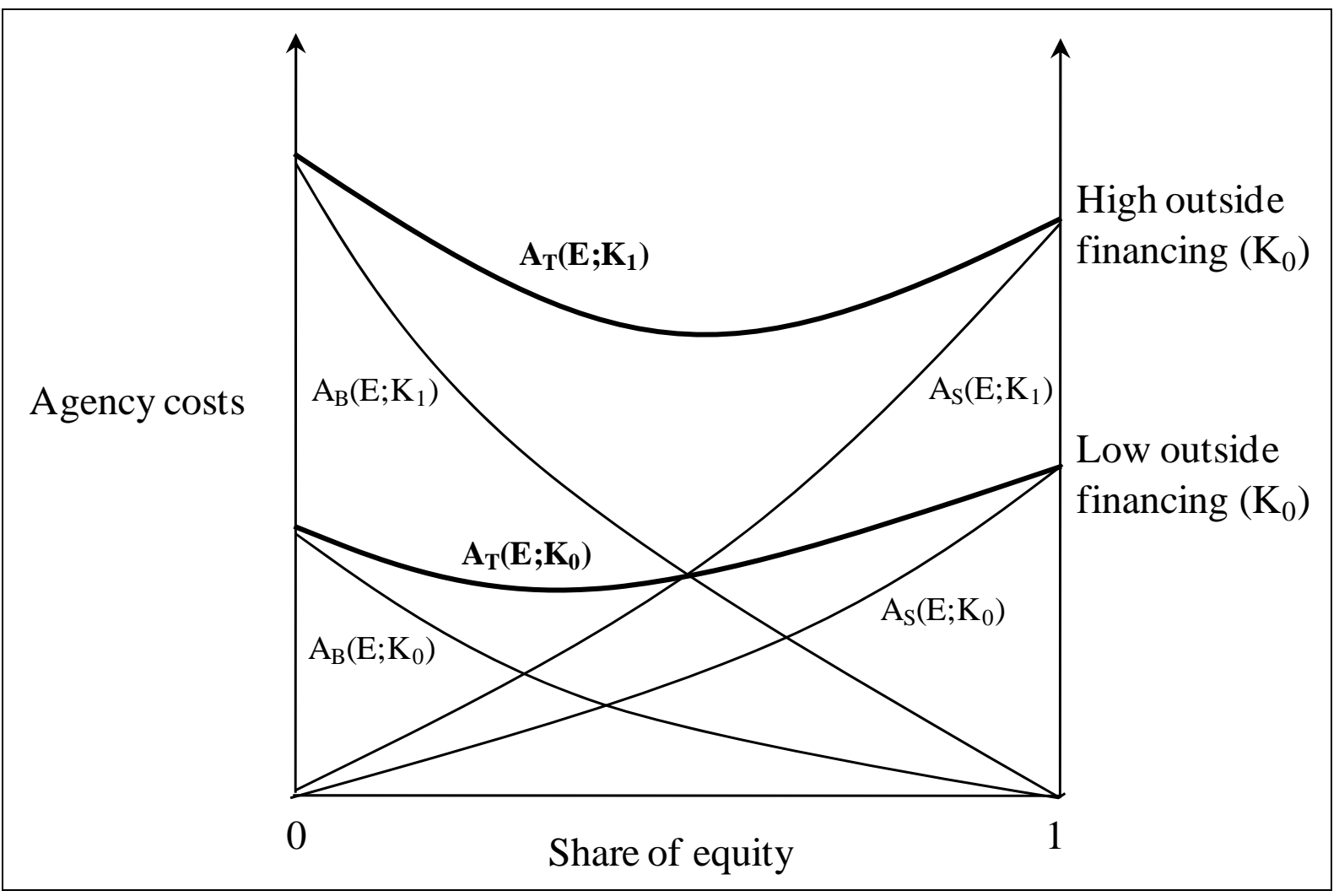

Figure 8: $\quad$ Agency cost functions for different levels of outside financing Source: $\quad$ JENSEN/MECKLING (1976), p. 363

\subsubsection{Underinvestment}

Besides the asset substitution problem, MYERS (1977) describes incentives for shareholders to underinvest, i.e. to ignore positive net present value (NPV) projects. In his model, the firm value consists of the market value of assets already in place and of the present values of future investment opportunities, which can be regarded as real options for shareholders. ${ }^{108}$ Building on BLACK/SCHOLES (1973), MYERS (1977) formally describes the owners' incentives to decide against investments in economically wealth creating projects. ${ }^{109}$

When an investment primarily creates cash flows which have to be used to satisfy the debt holders, equity holders may be better off if they refuse the investment. Ownermanagers tend to invest in projects which they expect to return enough to pay back

\footnotetext{
${ }^{108}$ Myers (1977), p. 150. Myers (1977) also states that already existing assets also have discretionary investments such as maintenance costs, which give them an option-like character.

${ }^{109}$ Note that wealth creating is referred to as undertaking positive NPV projects.
} 
debt holders and leave a positive residual claim for the shareholders. With increasing levels of debt, the more restrictive owner-managers will select investments, reducing growth opportunities and, therefore, the value of the firm. If unconstrained, equity holders may prefer to stop investing and pay out any available cash to them. ${ }^{110}$

Debt investors buy debt instruments assuming a predetermined dividend and investment policy of the issuing firm. In case the firm alters its dividend policy in a way that increases payouts to shareholders and thereby reduces investments, the value of debt is reduced. ${ }^{111}$ Consequently, dividend payments may be detrimental to debt holders. In the extreme case, the firm might sell all its assets and pay a liquidation dividend to shareholders, leaving debt holders with an 'empty shell'. ${ }^{112}$ Although the risk profile of the firm stays the same - assuming that the value of the assets equals the value of the firm -, the debt holder's claim is worthless. MYERS (1977) concluded that the limitation of payouts to shareholders is the most efficient way to mitigate the underinvestment problem. ${ }^{113}$

Another source of conflict rooted in the underinvestment problem, constitutes the socalled shortsighted investment problem. The large pressure on the borrowers' part, regarding the quick repayment of debt, makes borrowers tend to prefer investments that pay off quickly and allow them to meet their near-term debt obligations. In this way, shortsighted borrowers may favor lower NPV investment projects that pay off more quickly over more profitable projects with lower initial cash flows. ${ }^{114}$ An easy way for the debt holder to avoid this outcome, she could simply demand in the debt contract that all positive NPV projects have to be exercised. However, since the NPV of projects is not objectively observable for the most part of corporate investments this alternative is not valid.

\footnotetext{
${ }^{110}$ See De Matos (2001), p. 74. For an illustrative example see Malitz (1994), p. 5.

${ }^{111}$ Dividend payments might take different forms like cash dividend, share repurchase or affiliated transactions. Cf. Tirole (2006), p. 85.

${ }^{112}$ Cf. Tirole (2006), p. 85.

${ }^{113}$ Cf. Myers (1977), p. 164.

${ }^{114}$ Cf. Grinblatt/Titman (2002), p. 567-569.
} 


\subsubsection{Claim Dilution}

Shareholders might issue additional debt that is either secured or of same or higher seniority than outstanding debt. ${ }^{115}$ This action dilutes the claim of the original lenders and decreases the value of their claim. The value of outstanding debt is reduced by an increased loss given default - new debt holders receive part of the payoff in case of default - and an increased probability of default because of a higher debt service. MASULIS (1980) notes that if a firm takes on additional fixed claims, the existing debt holders are exposed to greater risk but receive the same interest payments.

Claim dilution is not limited to issuing additional debt. Other sources of diluting actions - which do not necessarily increase the value for the shareholder - are tax penalties, pension claims or legal claims. ${ }^{116}$ All of these claims have higher priority to outstanding debt and are therefore diluting existing claims from debt holders.

\subsubsection{Agency Costs of Debt}

The elaborated incentives from section 3.2.1 and the induced actions might decrease the value of debt and increase the value of equity and yet have no impact on the firm value. As value decreasing initiatives are anticipated by lenders, the ex ante price of debt and equity reflects the wealth transfer that might occur ex post, i.e. potential debt investors would anticipate detrimental actions ex post and price their debt accordingly. However, if this increase in the price of debt is justified by a proportional increase in equity value, shareholders would simply pay the higher price for debt ex ante. Only if the incentives induce actions that lead to agency costs, i.e. reduce the firm value, covenants might play a role. ${ }^{117}$

This section builds on the agency conflicts between debt holders and equity holders that result in agency costs of debt, which in turn are the rationale for the inclusion of covenants in credit agreements. To illustrate the effect, the section draws on the formal

\footnotetext{
${ }^{115}$ Cf. Smith/Warner (1979).

${ }^{116}$ Cf. Tirole (2006), p. 85. There is no impact on firm risk, if the investment policy of the firm is not affected.

117 Tirole (2006), p. 84.
} 
description of the asset substitution problem introduced in section 3.2.1.1. This example developed by JENSEN/MECKLING (1976) will show how agency costs of debt occur. $^{118}$

In this case, the shareholder increases his wealth $S$ by choosing the unanticipated riskier project, decreasing the market value of debt $B$. If the bondholders anticipate this opportunistic behavior of the owner-manager, they will only pay the market value of debt corresponding to project 2, $B_{2}$, for the face value of debt, $X^{*}$. In this case there is no wealth distribution between bondholders and shareholders and no welfare loss therefore also no agency costs.

However, there are cases where incentive effects do generate agency costs. If the expected value of the cash flow distribution in case of investment 2 is $E\left(X_{2}\right)$, which is lower than that of investment 1 , then the value of the firm with investment 1 is greater than the value of the firm if investment 2 is taken, i.e. $V_{1}>V_{2}$. If the difference in firm value is smaller than the difference in the values of debt, i.e. $\left(V_{1}-V_{2}\right)<\left(B_{1}-B_{2}\right)$, then the value of equity is larger when investment 2 is taken, $S_{1}<S_{2}$. Therefore, the owner-manager will choose investment $2 .{ }^{119}$ However, debt holders will not experience a wealth reduction as long as they ex ante perceive the motivation of the shareholder to choose investment 2 ex post and therefore only pay $B_{2}$ when the debt is issued. In this example the value of the firm is reduced by $V_{1}-V_{2}$ equaling the agency costs of debt that are borne by equity holders due to the anticipating behavior of the debt holder. However, equity holders might reduce agency costs of debt by accepting covenants written into the credit agreement.

\subsubsection{Agency Theory of Covenants}

The existing literature does not give a clear definition of the agency theory of covenants (ATC), as there are several seminal works that are cited as the foundations for this theory. The purpose of the ATC is to explain why covenants are included in such

\footnotetext{
${ }^{118}$ Although the author refers to the example of asset substitution, it is representative for all categories of incentive effects. Cf. Jensen/Meckling (1976), p. 350.

${ }^{119}$ This relation follows as $V_{1}-V_{2}=\left(S_{1}-S_{2}\right)+\left(B_{1}-B_{2}\right)$.
} 
debt contracts. JENSEN/MECKLING (1976) were the first to give a rationale for covenants based on an agency environment between shareholder and debt holder.

Some authors argue that SMITH/WARNER (1979) were the first to explicitly analyze and demonstrate the rationale behind covenants. However, they rather operationalized the theoretical foundations of JENSEN/MECKLING (1976) by developing the costly contracting hypothesis. The idea of the costly contracting hypothesis is that a debt issuing firm compares the costs and benefits of covenants, i.e. contractual restrictions of actions, leading to the value-maximizing set of terms in the bond contract. ${ }^{120}$ Other authors refer to MYERS (1977) as the foundation of the agency theory of covenants. Although MYERS (1977) gives a rationale for covenants, he builds on JENSEN/MECKLING (1976) extending their work by describing the underinvestment problem. ${ }^{121}$ Because MYERS (1977) and SMITH/WARNER (1979) are only extensions, this thesis builds on JENSEN/MECKLING (1976) to theoretically explain the agency theory of covenants.

The ATC assumes that rational debt holders anticipate the potential for opportunistic behavior by the shareholder and price the debt accordingly. Consequently, shareholders pay ex ante (at the time of issuance) for any potential expropriations they might attempt ex post. ${ }^{122}$ As shown in the example above, if the value reduction of debt is greater than the value increase of equity, these actions lead to agency costs, i.e. a reduced firm value. Thus, shareholders benefit if they reduce agency costs.

One way to minimize these costs is to write covenants into the debt's indenture that restrict the actions of the shareholder in the credit contract. However, the writing of covenants involves enforcement costs and reduced profitability due to the limitation of management's decision spectrum. Costs linked to covenants are called monitoring costs and are born by the shareholders through the pricing of the debt. ${ }^{123}$ The shareholder, who bears the monitoring costs, has incentives to minimize monitoring costs as

\footnotetext{
${ }^{120}$ Cf. also Nash/Netter/Poulsen (2003), p. 202f.

${ }^{121}$ Cf. Myers (1977), p. 150.

${ }^{122}$ Cf. Bradley/Roberts (2004), p. 5.

${ }^{123}$ Cf. Jensen/Meckling (1976), p. 350f.
} 
they reduce future cash flows, i.e. his residual claims. So, if the shareholder is able to provide the same outcome to the debt holder at lower cost, he will try to circumvent a covenant. The costs that occur in this case are called bonding costs. ${ }^{124}$

JENSEN/MECKLING (1976) give a formal illustration why shareholders will accept covenants. Suppose the debt holders will offer three options that they rate equivalent:

(i) a claim $X^{*}$ at the price $B_{2}$ without covenant and no guarantees from the owner-manager (represents a claim on investment 2).

(ii) a claim $X^{*}$ at the price $B_{1}$ without covenant but with guarantees from management that he will not deviate from his promised behavior at the bonding costs $b$ (represents a claim on investment 1 ).

(iii) a claim $X^{*}$ at the price $B_{1}-m$ with a covenant which guarantees that investment 1 will be made but leading to monitoring cost $m$ (represents a claim on investment 1$).{ }^{125}$

The shareholder now has the choice between these three options at the specified prices. If the bonding costs $b$ are different from the monitoring costs $m$, the shareholder will not be indifferent between incurring $b$ directly or including the covenant and letting the debt holder spend $m$, which is indirectly included in the specified price $B_{1}-m$, to guarantee that project 1 is taken. The wealth, $W$, of the owner-manager is given by the equity value plus the proceeds of the bond issue less the required investment. In the case of $m<b<\left(V_{1}-V_{2}\right)$, then the wealth hierarchy shows that $W_{i}<W_{i i}<W_{i i i}$. In this constellation the owner manager would voluntarily include a covenant in the debt issue and let the debt holder monitor his actions. ${ }^{126}$

The debt holders will have incentives to write covenants and monitor the ownermanager as long as the marginal benefits are greater than the marginal costs of such

\footnotetext{
${ }^{124}$ Jensen/Meckling (1976) use the example of detailed financial reports that debt holders might demand from the firm. If the owner-manager can produce this information and have it audited by independent auditors at lower cost than the debt holders, he will opt for bonding costs in contrast to monitoring costs.

${ }^{125}$ Cf. Jensen/Meckling (1976), p. 352.

${ }^{126}$ Cf. Jensen/Meckling (1976), p. 352.
} 
activities. The covenants that the debt holder will write into the credit agreement based on the ATC are covenants that restrict the actions of the owner-shareholder. This class of covenants is therefore defined as action-restricting covenants in this thesis.

\subsection{The Control View - Financial Contracting Theory}

\subsubsection{Contractual Incompleteness}

The ATC implies that the incentive effects of debt lead to a potential reduction in firm value. Therefore, shareholders are willing to limit their actions through the usage of covenants to reduce agency costs of debt and increase the firm value. However, JENSEN/MECKLING (1976) do not consider decision rights and contractual incompleteness. ${ }^{127}$ GROSSMAN/HART (1986) and HART/MOORE (1990) developed the theory of incomplete contracts from transaction cost literature, mainly based on COASE (1937) and WILLIAMSON (1979). ${ }^{128}$ Contractual incompleteness means that potentially optimal contracts under the principal agent framework are constrained by important variables that are difficult to foresee ex ante and must be left out of the contract. These variables are ex post observable by the contract parties but not observable by third parties and therefore they are not verifiable and the potential payoffs not enforceable. This framework of incomplete contracts is known as the Grossman-HartMoore (GHM) approach. According to HART (1995) there are three factors causing the incompleteness of contracts:

a. '... in a complex and highly unpredictable world, it is hard for people to think far ahead and to plan for all the various contingencies that may arise ... ${ }^{129}$

\footnotetext{
${ }^{127}$ Another important distinction between the agency theory and the theory of incomplete contracts is that managerial actions, e.g., level of effort or perks, are non-transferable, whereas control rights are transferable. Cf. Hart (2000), p. 11.

${ }^{128}$ The theory of incomplete contracts was critiqued heavily for the lack of theoretic foundations, especially by Maskin/Tirole (1999). However, Hart/Moore (1999) extended the original model providing a rigorous foundation that contracts are at least partially incomplete.

${ }^{129}$ Cf. Hart (1995), p. 23.
} 
b. '... even if individual plans can be made, it is hard for the contracting parties to negotiate about these plans ... ${ }^{130}$

c. '... even if the parties can plan and negotiate about the future, it may be difficult for them to write their plans down in such a way that, in the event of a dispute, an outside authority - a court, say - can figure out what these plans mean and enforce them ..., ${ }^{131}$

The work of GROSSMAN/HART (1986) and HART/MOORE (1990) is primarily concerned with costs and benefits of ownership and develops the theory in the context of vertical integration, i.e. the broader question of the size of the firm. Their models emphasize that contractual incompleteness might lead to incentive disruptions where the agent does not receive the ex post return which is required to compensate him for his ex ante efforts, i.e. investments. For example in the case of vertical integration, if firm $x$ owns firm $y$, firm $x$ uses its control rights to receive most of the ex post profits, which will induce firm $\mathrm{x}$ to overinvest and firm $\mathrm{y}$ to underinvest. In contrast, in the case of non-integration, the ex post profits will be divided more symmetrically and the firms have reduced incentives to over- or underinvest. ${ }^{132}$

In their paper, GROSSMAN/HART (1986) also mention other incentive distortions of incomplete contracts due to risk aversion of parties. In their idea, an entrepreneur (they utilize manager) has an investment project but wants to avoid the risk of financing it on his own (they assume that there is no wealth constraint). In order to realize the investment he raises the funds from a risk neutral investor. If the entrepreneur retains full control over the investment, he may be able to increase his benefits (pecuniary as well as non-pecuniary) ex post - while simultaneously reducing the benefits (pecuniary only) for the investor - by exploiting non-contracted rights (as he is the owner of the investment, he has all the residual rights which are not specifically defined in the contract). Anticipating the potential wealth reducing effect of 'noncontractibles' the inves-

\footnotetext{
${ }^{130}$ Cf. Hart (1995), p. 23.

${ }^{131}$ Cf. Hart (1995), p. 23. In the agency theory of covenants, the restricted actions were assumed to be contractible and enforceable.

${ }^{132}$ Cf. Grossman/Hart (1986), p. $716 f$.
} 
tor may restrict his funding. To encourage the investment from the external investor the entrepreneur has to transfer the investor some kind of control by giving him partial ownership. ${ }^{133}$ However, contractual features of financial instruments are not the focus of GHM.

\subsubsection{The Aghion-Bolton Model}

The financial contracting literature applied the GHM approach to the financial structure of firms, extending the GHM approach by introducing wealth constraints. In this context, financial structure is defined as the set of characteristics of the financial contracts linked to the utilized financial instrument, for instance debt or equity. Financial contracting is therefore an instrument to reduce agency costs by allocating control rights of the firm in a way which optimizes the decision process for possible future states to be revealed and not covered by incomplete contracts. Therefore, the financial structure and consequently the implicit control rights are designed to maximize the value of the firm. ${ }^{134}$

In this tradition AGHION/BOLTON (1992) construct a model of capital structure based on control rights and incomplete contracts. Their model considers a situation where the agent is wealth constrained - this is the main difference to the GHM approach - and has to raise external funds to purchase the asset or conduct the project. ${ }^{135}$ In this constellation the agent may behave opportunistically and reduce the principal's wealth. To protect himself against expropriating actions from the agent, the principal will choose from a menu of levers, for example covenants, repayment characteristics or convertibility of the loan.

The model assumes a bilateral contracting problem where a wealth constrained entrepreneur, $E$, tries to raise funds from the external investor, $I$, to finance the investment, $K$. The timeline of the model is shown in Figure 9). The investor is willing to invest in

\footnotetext{
${ }^{133}$ Cf. Grossman/Hart (1986), p. 716f.

${ }^{134}$ Cf. De Matos (2001), p. $125 f$.

${ }^{135}$ Note that the Aghion-Bolton Model was derived for entrepreneurial firms; however, the basic setting also holds for firms with separated control and ownership.
} 
the project if the contract yields an expected return of at least $K$ (investor's individual rationality constraint). In $\mathrm{t}=0$ the investor, $I$, finances investment $K$. In $\mathrm{t}=1$ the state of the nature, $\theta$, which is not observable is approximated by signal $s$. After the signal $\mathrm{s}$ is revealed, action a is taken by $E$, which has an impact on the final return, $r$. The timeline of the project is shown in Figure 9.

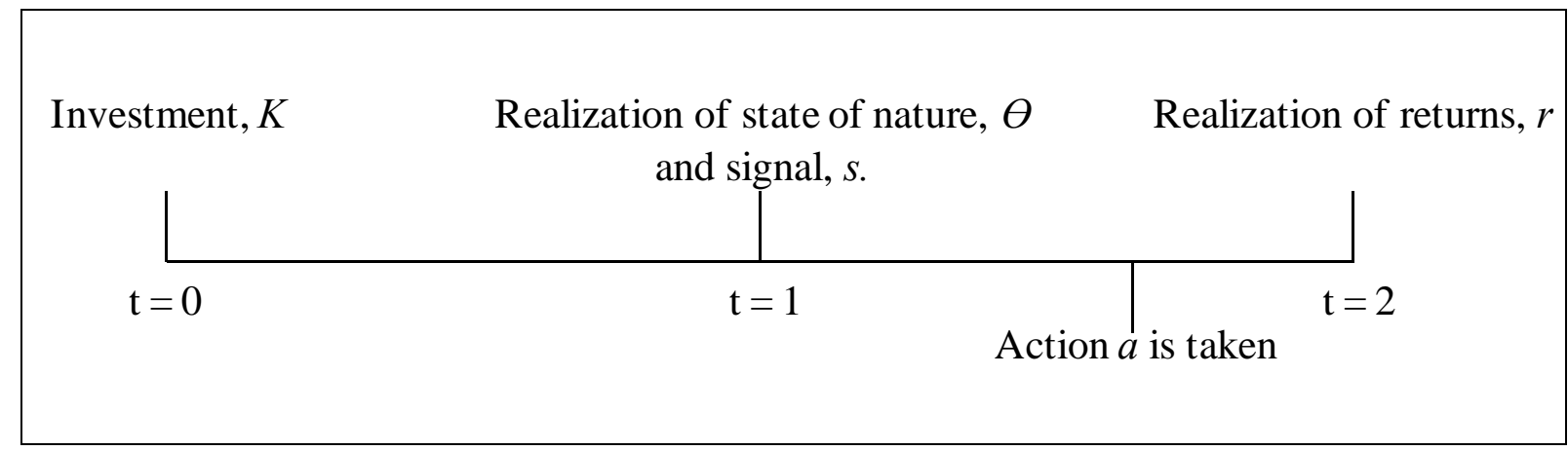

Figure 9: $\quad$ Technological characteristics of project timeline Source: $\quad$ AGHION/BOLTON (1992), p. 476.

The Von-Neumann-Morgenstern utility functions ${ }^{136}$ can be denoted as $U_{E}(r, a)$ and $U_{I}(r, a):^{137}$

$$
\begin{gathered}
U_{E}(r, a)=r+l(a, \theta) \\
U_{I}(r, a)=r .
\end{gathered}
$$

While the investor is only concerned with the monetary return, i.e. cash flows of the project, the entrepreneur derives utility from cash flows as well as non-pecuniary (private) benefits as discussed in JENSEN/MECKLING (1976), like reputation, perks, effort. These private benefits are neither observable nor verifiable and depend on the state of the nature as well as on the choice of action and are denoted as $l(a, \theta)$. This constellation might lead to potential conflict of interests regarding the action between the entrepreneur and the investor. Given this setting, AGHION/BOLTON (1992) an-

\footnotetext{
${ }^{136}$ Von-Neumann-Morgenstern utility functions fulfil the four axioms of completeness, transitivity, continuity and independence. Cf. von Neumann/Morgenstern (1953), p. 27.

${ }^{137}$ Additionally, symmetric information and a zero interest rate are assumed.
} 
swer two questions: (i) what is the structure of the initial contract that perfectly aligns the objectives between the entrepreneur and the investor and (ii) if no perfect alignment is available how should control rights be allocated?

As contracts are assumed to be incomplete the state of the nature $\theta$ is impossible or very costly to describe ex ante but verifiable for both parties ex post. ${ }^{138}$ AGHION/BOLTON (1992), differing from GROSSMAN/HART (1986), assume that contracts can be made contingent on a verifiable signal, $s$, at $\mathrm{t}=1$ which is correlated with $\theta$. In the real world this signal might be determined for example by performance, which might be monitored by financial covenants.

Further simplifying assumptions of the model are formalized as follows:

- There are two states of nature, abbreviated $g$ for good and $b$ for bad: $\Theta=\left\{\theta_{g} ; \theta_{b}\right\}$

- There are two possible actions: $\mathrm{A}=\left\{a_{g} ; a_{b}\right\}$, where $a_{g}=a^{*}\left(\theta_{g}\right)$ is the first best choice action in state $\theta_{g}$ and $a_{b}=a^{*}\left(\theta_{b}\right)$ is the first best choice action in state $\theta_{b}$.

- There are two possible outcomes for the signal s in period 1 : $s \in\{0 ; 1\}$, let $\beta^{\theta}$ denote the probability that $s=1$ given $\theta$. The two conditional probabilities are then defined as:

$$
\left\{\begin{array}{l}
\beta^{g} \equiv \operatorname{Prob}\left(s=1 \mid \theta=\theta_{g}\right)>1 / 2 \\
\beta^{b} \equiv \operatorname{Prob}\left(s=1 \mid \theta=\theta_{b}\right)<1 / 2
\end{array}\right.
$$

Note that $\beta^{g}=1$ and $\beta^{b}=0$ imply that $s$ is a perfect proxy for $\theta$ and the contract is consequently not incomplete. The degree of incompleteness of the contract can be measured as the sum of the deviation of $\beta^{g}$ from 1 and $\beta^{b}$ from 0 , formally:

\footnotetext{
${ }^{138}$ These assumptions are identical to Grossman/Hart (1986).
} 


$$
d=\left|\beta^{g}-1\right|+\beta^{b}
$$

- The expected rate of return in the final period $(\mathrm{t}=2) y_{j}^{i}$, with $j$ denoting the action taken and $i$ denoting the state of the nature (notation valid for all variables), may take only two values: $\mathrm{r}=1$ or $\mathrm{r}=0$. The expected return depends on both the undertaken action $a$ as well as the state of the nature $\theta$ :

$$
y_{j}^{i}=E\left[r \mid \theta=\theta_{i} ; a=a_{j}\right]
$$

- Private benefits of the entrepreneur are denoted as $l_{j}^{i}$ and the optimality of $a_{g}$ and $a_{b}$ are by definition:

$$
\left\{\begin{array}{l}
y_{g}^{g}+l_{g}^{g}>y_{b}^{g}+l_{b}^{g} \\
y_{b}^{b}+l_{b}^{b}>y_{g}^{b}+l_{g}^{b}
\end{array}\right.
$$

- The project is assumed to be only feasible if the investor realizes a positive NPV for the first-best pair of actions, with $q$ being the probability of a good state:

$$
q y_{g}^{g}+(1-q) y_{b}^{b}>K
$$

- The entrepreneur is compensated with a monetary transfer, which is a function of the signal in $\mathrm{t}=1$ and the return realization in $\mathrm{t}=2$, formally $t(s, r)$, which is equal or greater than zero. As the second-period return can only take two values ( 0 and 1 ) the transfer schedule is composed of a variable and a fixed part with $t_{s}$ and $t_{s}^{\prime}$ being constants:

$$
t(s, r)=(t(s, 1)-t(s, 0)) r+t(s, 0)=t_{s} r+t_{s}^{\prime} \geq 0
$$


All residual returns go to the investor. Hence, the utility function the entrepreneur would maximize $t_{s} y_{j}^{i}+t_{s}^{\prime}+l_{j}^{i}$ and the investor would maximize $\left(1-t_{s}\right) y_{j}^{i}-t_{s}^{\prime}$.

The model will help to understand how the entrepreneur and the investor settle an ex ante agreement and dependent on who of them has control over action $a$ after the state of the nature is revealed.

\section{Entrepreneur is in control}

In this case the entrepreneur has full control, i.e. the entrepreneur chooses action $a$. She will choose the action $a$ which maximizes her utility function:

$$
a^{E}\left(\theta_{i}, s\right)=\underset{a_{j}}{\operatorname{argmax}}\left\{t_{s} y_{j}^{i}+t_{s}^{\prime}+l_{j}^{i}\right\}
$$

In this context a contract is efficient if the action chosen is optimal, i.e. value maximizing for the sum of utilities of the entrepreneur and the investor (social objectives), for the realized state of the nature. A contract is feasible if the investor expects to yield at least his invested amount $K$.

In the simple case where the entrepreneur's objectives are in line with social objectives, entrepreneur control is efficient and feasible. Private benefits are defined to be comonotonic with the value of social objectives $(y+l)$. Formally comonotonic private benefits can be described as:

$$
\left\{\begin{array}{l}
t+l_{g}^{g}>t+l_{b}^{g} \\
t+l_{b}^{b}>t+l_{g}^{b}
\end{array}\right.
$$

After the state of the nature is reveals the entrepreneur will always choose the correct action, i.e. in a good state the entrepreneur will always choose $a_{g}$ to maximize his utility, which also maximizes the utility of the investor - and vice versa for the bad state. The contract is also feasible, as there always exists a constant $t$ that fulfills $q y_{g}^{g}+$ 
$(1-q) y_{b}^{b}-t=K$ as $q y_{g}^{g}+(1-q) y_{b}^{b}>K$ and $t \geq 0$. AGHION/BOLTON (1992) derive their first proposition from this case:

Proposition 1: If private benefits are comonotonic with social objectives $(y+l)$, then entrepreneur control is always efficient and feasible.

However, if private benefits are not comonotonic with total revenues, the action chosen by the entrepreneur may not be the one that maximizes the value of the project and may not be feasible. The first-best action plan can be achieved in this case if the entrepreneur gets sufficient monetary returns to make him choose the efficient action in every state. The monetary return can be directly specified by the transfer schedule or by indirectly by renegotiation. But this requirement might reduce the returns to the investor to below the level where the project is feasible.

The decision to renegotiate or not depends on the fee schedule. So, before looking at efficiency, one has to show that there are sufficient conditions that guarantee the feasibility of the contract. Therefore, the contract has to induce the entrepreneur to choose $a_{b}$ in a bad state of nature, which can be described as:

$$
t_{s} y_{b}^{b}+l_{b}^{b} \geq t_{s} y_{g}^{b}+l_{g}^{b}
$$

Where the lower bound (by subtracting the right side from the left side and setting the resulting equation equal to zero) can be denoted as:

$$
\dot{t} \equiv \frac{l_{g}^{b}-l_{b}^{b}}{y_{b}^{b}-y_{g}^{b}}
$$

There are three different scenarios. First, for the contract with $t_{s}=\dot{t}$ to be feasible, the expected payoff is required to be greater than $K$, denoted by $\pi_{1}$ :

$$
\pi_{1} \equiv q(1-\dot{t}) y_{g}^{g}+(1-q)(1-\dot{t}) y_{b}^{b} \geq K
$$


Consequently, this case is only feasible if $\mathrm{K}$ is lower than the expected payoff or the fee schedule is high enough (meaning $t_{s} \geq \dot{t}$ ).

Second, for the contract with $t_{s}<\dot{t}$ for $s=0,1$. In this case, there is no $t$ that monetarily compensates the entrepreneur for switching to $a_{b}$ in a bad state of nature. Consequently, she will always choose $a_{g}$, given $l_{b}^{b}<l_{g}^{b}$. Within this case the return for the investor is maximized for $t_{s}=0$, irrespective of the signal. The contract to be feasible the return for the investor $\pi_{2}$ is greater than $\mathrm{K}$ :

$$
\pi_{2} \equiv q y_{g}^{g}+(1-q) y_{g}^{b} \geq K
$$

Since $y_{b}^{b}>y_{g}^{b}$ there is an incentive to renegotiate. The investor is willing to pay up to $y_{b}^{b}-y_{g}^{b}$ for the entrepreneur to choose action $a_{b}$ in state $\theta_{b}$. As the entrepreneur has all the bargaining power, the ex ante payoff to the investor is reduced to $\pi_{2}$ after the renegotiation.

Third, the investor's expected payoff is maximized for an optimal schedule such that $t_{0}=\dot{t}$ for $s=0$ and $t_{1}=0$ for $s=1$. Consequently, if $\mathrm{s}=1$ and the state of the nature is $\theta_{b}$, the entrepreneur will choose $a_{b}$, given $l_{b}^{b}<l_{g}^{b}$ and there is no monetary compensation $\left(t_{1}=0\right)$ to induce the entrepreneur to choose $a_{g}$. However, the investor will then renegotiate the contract to induce the entrepreneur to choose $a_{g}$. The ex ante expected profit for the investor can then be described as: ${ }^{139}$

$$
\begin{aligned}
\pi_{3} \equiv q\left[\beta_{g} y_{g}^{g}\right. & \left.+\left(1-\beta_{g}\right) y_{g}^{g}(1-\dot{t})\right]+(1-q)\left[\beta_{b} y_{g}^{b}\right. \\
& \left.+\left(1-\beta_{b}\right) y_{b}^{b}(1-\dot{t})\right]
\end{aligned}
$$

The contract is feasible if $\pi_{3} \geq K$. In summary, following proposition can be formulated:

\footnotetext{
${ }^{139}$ For a detailed derivation of equation (15) see Aghion/Bolton (1992), p. 493f., or De Matos (2001), p. 265f.
} 
Proposition 2: Entrepreneur control for non-comonotonic private benefits is efficient and feasible if and only if $\max \left(\pi_{1}, \pi_{2}, \pi_{3}\right) \geq K$.

Investor is in control

In contrast to the theoretical considerations above, this paragraph now analyzes the situation where the investor decides on action $a$, avoiding every opportunistic behavior of the entrepreneur. Analogous to the previous sections, if the investor does not choose the efficient action, renegotiations take place. But, as the entrepreneur is wealth constrained, renegotiation may not take place as the entrepreneur has to compensate the investor to induce another action.

Similar to entrepreneurial control, if monetary benefits are comonotonic with social objectives and the proportional schedule $t(s, r)=\bar{t} r$, then the contract is efficient since:

$$
(1-\bar{t}) y_{g}^{g}>(1-\bar{t}) y_{b}^{g}
$$

Additionally, the contract is feasible since values of $\bar{t}$ exist, which fulfill:

$$
q y_{g}^{g}+(1-q) y_{b}^{b}>K
$$

Proposition 3: When monetary benefits are comonotonic with social objectives investor control is always efficient and feasible.

If monetary returns are not comonotonic with social objectives, a renegotiation at $\mathrm{t}=1$ may lead to the first best action (i.e. Pareto-improving renegotiation). If $y_{g}^{g}<y_{b}^{g}$, $t_{s} \leq 1$ and $t_{s}^{\prime}=0$ the investor will choose $a_{b}$ in state $\theta_{g}$ because:

$$
\left(1-t_{s}\right) y_{g}^{g}<\left(1-t_{s}\right) y_{b}^{g}
$$

To convince the investor to make a different choice of action, the entrepreneur has to renegotiate the contract to redefine, i.e. reduce $t_{s}$. The renegotiated $\tilde{t}_{s}$ must then satisfy 


$$
\begin{gathered}
\left(1-\tilde{t}_{s}\right) y_{g}^{g} \geq\left(1-t_{s}\right) y_{b}^{g} \\
\tilde{t}_{s} \leq 1-\left(1-t_{s}\right) \frac{y_{b}^{g}}{y_{g}^{g}}
\end{gathered}
$$

Consequently, there are scenarios (large ratio of $\frac{y_{b}^{g}}{y_{g}^{g}}$ or a small $t_{s}$ ) where $\tilde{t}_{s}$ becomes negative and thus make a renegotiation impossible since the entrepreneur has no additional wealth left outside the project to cover the necessary compensation for the investor. Consequently, the entrepreneur's wealth constraint prevents him from offering a Pareto-improving contract to the investor.

To derive the expected payoff for the investor, we know that if $t_{s}=\tilde{t}_{s}$ then the entrepreneur induces the investor to choose $a_{g}$ in $\theta_{g}$. In $\theta_{b}$ the fee schedule $t_{s}=t$ and the investor will choose $a_{b}$. It can be followed:

$$
\begin{aligned}
\pi_{4} \equiv q\left(1-\tilde{t}_{s}\right) y_{g}^{g}+(1-q)(1-t) y_{b}^{b} \\
=q\left[\left(1-t_{s}\right) \frac{y_{b}^{g}}{y_{g}^{g}}\right]+(1-q)(1-t) y_{b}^{b}
\end{aligned}
$$

Given $\tilde{t}_{s} \geq 0$ it follows that $\left(1-t_{s}\right) \frac{y_{b}^{g}}{y_{g}^{g}} \leq 1$ and therefore $t_{s} \geq 1-\frac{y_{g}^{g}}{y_{b}^{g}}$. Since the actions are independent from signal s and therefore $t_{s}=t$, we substitute $(1-t)=\frac{y_{b}^{g}}{y_{g}^{g}}$ and arrive at:

$$
\pi_{4} \equiv \frac{y_{b}^{g}}{y_{g}^{g}}\left[q y_{b}^{g}+(1-q) y_{b}^{b}\right]
$$

From this payoff equation one can follow: 
Proposition 4: When monetary benefits are not comonotonic with social objectives a necessary and sufficient condition for an efficient and feasible contract under investor control is $\pi_{4} \equiv \frac{y_{b}^{g}}{y_{g}^{g}}\left[q y_{b}^{g}+(1-q) y_{b}^{b}\right] \geq K$

\section{Contingent control}

Besides these two unilateral control forms, contingent control, i.e. the entrepreneur stays in control until a prespecified signal occurs, might be an effective alternative. When neither private benefits nor monetary returns are comonotonic with social objectives, entrepreneur control might not be feasible and investor control might not produce an efficient action plan (see above). In the case where $y_{g}^{g}<y_{b}^{g}$ and $l_{b}^{b}<l_{g}^{b}$, a contingent control allocation may lead to a domination of investor and entrepreneur control. ${ }^{140}$ The contingency, i.e. the shift in control, depends on the realization of the signal $s$.

For these parameters for monetary and private benefits, in a bad state of the nature $\theta_{b}$ investor control produces an efficient action plan (independent of the realization of $s$ ) and in a good state of the nature $\theta_{g}$ entrepreneur control is efficient. Consequently, it would be efficient to make the control contingent on the state of the nature. However, as the state of the nature cannot be verified, control can only be made contingent on the realization of $s$. But, if $s$ is sufficiently well correlated with the state of the nature a contingent control allocation where control is allocated to the entrepreneur when $s=1$ and the investor when s=0 may approximate an efficient action plan.

In the case of contingent control allocation and the transfer schedule such that $t(s, r)=0$ for all $s$ and $r$, following action plan is induced in the absence of renegotiations:

$$
\text { in state } \theta_{g}, \quad a= \begin{cases}a_{g}, & \text { if } s=1 \\ a_{b}, & \text { if } s=0\end{cases}
$$

\footnotetext{
${ }^{140}$ If either monetary of private benefits are comonotonic, one of the two unilateral control allocations leads to an efficient action plan, which cannot be dominated.
} 


$$
\text { in state } \theta_{b}, \quad a= \begin{cases}a_{g}, & \text { if } s=1 \\ a_{b}, & \text { if } s=0\end{cases}
$$

As the entrepreneur obtains all the rents from renegotiation, the investor's expected return from this action plan is given:

$$
\pi_{c} \equiv q\left[\beta_{g} y_{g}^{g}+\left(1-\beta_{g}\right) y_{b}^{g}\right]+(1-q)\left[\beta_{b} y_{g}^{b}+\left(1-\beta_{b}\right) y_{b}^{b}\right]
$$

Testing the limits for $\beta^{\mathrm{g}}$ and $\beta^{\mathrm{b}}$ and the implications on $\pi_{\mathrm{c}}$ the contingent control allocation is compared against the unilateral payoffs $\pi_{1}, \pi_{2}, \pi_{3}$ and $\pi_{4}$. When $\beta^{\mathrm{g}} \rightarrow 1$ and $\beta^{b} \rightarrow 0$ then $\pi_{c}=q y_{g}^{g}+(1-q) y_{b}^{b}$ and consequently $\pi_{c}>\pi_{1}$ and $\pi_{2}$, therefore contingent control dominates entrepreneur control. However, when $\beta^{\mathrm{g}} \rightarrow 1$ and $\beta^{\mathrm{b}} \rightarrow 0$, $\pi_{3}$ may also converge to the first-best payoff. When calculating $\pi_{c}-\pi_{3}$ one observes $^{141}$ that $\pi_{c}>\pi_{3}$ and therefore when $\beta^{g} \rightarrow 1$ and $\beta^{b} \rightarrow 0$ (i.e. $s$ is well correlated with the state of the nature), there exist values for $K$ for which contingent control is feasible but entrepreneur control is not (because $\pi_{c} \geq \pi_{1}, \pi_{2}, \pi_{3}, \pi_{4}$ ).

In the following contingent control is compared to investor control. Again consider the limit case where $\beta^{\mathrm{g}}=1$ and the condition $\pi_{4} \geq \mathrm{K}$ is violated. Consequently, investor control induces action $a_{b}$ in state $\theta_{g}$ which is not the first-best, i.e. efficient, action. Under contingent control, as $\beta^{\mathrm{g}} \rightarrow 1$ and $\beta^{\mathrm{b}} \rightarrow 0$, total payoffs converge to the firstbest social objectives, so that contingent control approaches efficiency and strictly dominates investor control.

Proposition 5: When neither monetary nor private benefits are comonotonic with social objectives there are values of $K$ such that:

(i) Entrepreneur control is not feasible.

(ii) Investor control is not efficient.

\footnotetext{
${ }^{141}$ For a detailed derivation of this consequence see Aghion/Bolton (1992), p. 485.
} 
(iii) Both unilateral control allocations are dominated by the contingent control allocation defining $a_{b}$ if $s=0$ and $a_{g}$ if $s=1$ as the degree of incompleteness in equation (4) approaches zero.

The contingent control allocation can be interpreted as the characteristics of debt financing: the entrepreneur is in control as long as signal $s$ shows 'no default' and the investor, i.e. the creditor, gets control when the entrepreneur is in 'default'. ${ }^{142}$ As already pointed out by AGHION/BOLTON (1992) their model theoretically enhances the rationality of debt financing. Besides the signaling role ${ }^{143}$, the role of facilitating monitoring ${ }^{144}$, free-cash-flow role ${ }^{145}$, or the payout role ${ }^{146}$, debt financing allows the entrepreneur to reap some private benefits as long as she is not in default. When the entrepreneur is in default, the investor receives control rights and can limit the extraction of private benefits through renegotiation. ${ }^{147}$ TIROLE (2006) comments that contingent control rights increase the pledgeable income, i.e. boosts borrowing capacity. ${ }^{148}$

Until now, actions were assumed to be non-verifiable. It is interesting to see what happens if actions taken are verifiable and therefore can be restricted ex ante - like actionrestricting covenants. In anticipating ex post opportunistic actions from the entrepreneur, the investor will limit these actions. If such instruments are available, control rights might be redundant for the investor. AGHION/BOLTON (1992) show that restricting the action set of the entrepreneur may in fact reduce the entrepreneur's future renegotiation rents. In their case with two possible actions, action-restricting is redundant to control rights. But when the action plan comprises more than two actions, ex

\footnotetext{
${ }^{142}$ If the business is financed with common equity issuance the investor receives full control. And if the entrepreneur receives full control the project is financed with preferred equity. Cf. Aghion/Bolton (1992), p. 486.

${ }^{143}$ Cf. Myers/Majluf (1984).

${ }^{144}$ Cf. Townsend (1979).

${ }^{145}$ Cf. Jensen (1986).

${ }^{146}$ Cf. Hart/Moore (1990).

${ }^{147}$ Cf. Myers/Majluf (1984), Townsend (1979), Jensen (1986), Hart/Moore (1990).

${ }^{148}$ Cf. Tirole (2006), p. 394.
} 
ante action restriction improves the overall efficiency of the contract. In general, when actions are verifiable ex post, contractual agreements should include control allocation and action restrictions.

First, action restrictions in the initial contract can reduce ex post opportunism on the entrepreneur's side and reduce the investor's payoff constraint $K$. Second, allowing some scope for flexibility (i.e. not all actions are pre-specified) reduces the likelihood of future renegotiations. ${ }^{149}$ This finding explains the existence of financial contracts that combine control allocations and action restrictions, such as debtcontracts with financial and action-restricting covenants. ${ }^{150}$

In this context, financial covenants can be understood as the instrument that transmits the signal $s$ that is supposed to reveal the state of the nature. ${ }^{151}$ Therefore, financial covenants are tied to firm performance, assuming that the chosen accounting variables, like current ratio (current assets/current liabilities) or debt to EBITDA, are sufficiently correlated with the state of the nature and do have a forecasting character. A breached financial covenant threshold indicates a bad state of the nature, which induces a shift of control rights to creditors and limits private benefit extraction (e.g., low effort, asset substitution etc.) of the entrepreneur going forward. ${ }^{152}$

A potential shift in control rights following a covenant breach does not necessarily mean that debt holders take over the management of a firm in covenant breach. More often, debt holders renegotiate the contract and demand a higher payoff for their investment, more restrictive covenants and a change in corporate policy. ${ }^{153}$ However, a

\footnotetext{
${ }^{149}$ For a detailed derivation of this optimal structure please refer to Aghion/Bolton (1992), p. 487f.

${ }^{150}$ Cf. Aghion/Bolton (1992), p. 489.

${ }^{151}$ In contrast to Aghion/Bolton (1992) who refer to the signal as the non-payment of interest or principal from the loan, Tirole (2006) also adds financial covenant violation as the signal to trigger a shift in control rights. Cf. Tirole (2006), p. 84f.

${ }^{152}$ Note that many scholars refer to the theoretic rationale of financial covenants to Aghion/Bolton (1992), like for example Chava/Roberts (2008). However, Aghion/Bolton (1992) explain capital structure choices based on control characteristics of different financing instruments and create a 'pecking order' based on incomplete contracts. Nevertheless, they do not give a rationale for financial covenants in particular as they refer to covenants as action-restricting covenants.

${ }^{153}$ Cf. Tirole (2006), p. 86.
} 
potential covenant breach has implications for shareholders and management which leads to additional indirect effects of financial covenants.

\subsubsection{The Rajan-Winton Model}

The previous section formally demonstrated that contingent control dominates entrepreneur or investor control in certain circumstances. Nevertheless, short fixed maturities would give lenders even greater flexibility and control as they could simply liquidate at the end of the loan. However, this leads lenders to liquidate too often. ${ }^{154}$ So, RAJAN/WINTON (1995) ask the question why lenders decide for the more complex route of long-term loans and obtaining control through financial covenants? To answer this question they design a model that will be briefly explained in the following.

In a model with three time periods, an entrepreneur without funds needs to finance an investment $I$ at time 0 . At time 1 signals of the state of the firm and probabilities of success are observed. Also, at this point in time the firm's assets may be liquidated for the value $\gamma \mathrm{L}_{1} \cdot{ }^{155}$ If the firm is not liquidated at time 1 , then at time 2 it either returns cash flows $X$ or fails. In both states at time 2, the firm has the residual value of $\mathrm{L}_{2}$. The hierarchy of values is $\mathrm{L}_{2}<\mathrm{L}_{1}<X+\mathrm{L}_{2}$. This order ensures that there exists a chance that implies liquidation at time 1.

The chance that the project will succeed at time 2 as of time 0 is $p \in(0,1)$. At time 1 , the entrepreneur of the firm receives the precise signal $\theta$ of the project's chance of success in the next period, with $\theta \in\left\{\theta_{1}, \theta_{2}\right\}$, with both signals being equally likely and $0 \leq \theta_{1}<\theta_{2} \leq 1$. Outsiders can observe $\theta$ as well, but only if they monitor that incurs the monitoring cost $c$.

Compared to the costly signal $\theta$, the noisy signal $\pi \in\left\{\pi_{1}, \pi_{2}\right\}$ is publicly available for free to outsiders. The probability of $\pi_{i}$ given $\theta_{\mathrm{i}}$ is $\beta$, with $0.5<\beta<1$ and the unconditional probabilities of $\pi_{1}$ and $\pi_{2}$ are 0.5 . It follows that $\pi_{1}=\beta \theta_{1}+(1-\beta) \theta_{2}$ and

\footnotetext{
${ }^{154}$ Cf. Diamond (1993).

${ }^{155}$ For reasons of simplicity the scale factor $\gamma$ is set to 1 .
} 
$\pi_{2}=(1-\beta) \theta_{1}+\beta \theta_{2}$, and $\theta_{1}<\pi_{1}<\pi_{2}<\theta_{2}$. An overview of the characteristics of the different signals is shown in Figure 10.

$\pi$... noisy signal of the project's chance of success; publicly available but not verifiably in courts

$\theta$... true signal of the project's chance of success; monitoring occurs for monitoring cost $c$, not verifiably in courts

$\varphi$... signal of the project's chance of success; verifiable and obtained through monitoring and correlated to $\theta$

Figure 10: Overview of different signals obtained by the investor

Source: $\quad$ Author extracted from RAJAN/WINTON (1995), p. 1118.

However, neither the private signal $\theta$ nor the public signal $\pi$ are verifiable in courts, which implies that they cannot be contracted upon. But, in case the investor monitors, he observes also the signal $\varphi$ which is verifiable and consequently contracted upon. The probability of $\varphi_{i}$ given $\theta_{\mathrm{i}}$ is $\alpha$, with $0.5<\alpha<1$ and the unconditional probabilities of $\varphi_{1}$ and $\varphi_{2}$ are 0.5 . It follows that $\varphi_{1}=\alpha \theta_{1}+(1-\alpha) \theta_{2}$ and $\varphi_{2}=$ $(1-\alpha) \theta_{1}+\alpha \theta_{2}$, and $\theta_{1}<\varphi_{1}<\varphi_{2}<\theta_{2}$.

The aim of the entrepreneur is to finance investment $I$ from outside investors with a contract that maximizes the firm value. Contracts can enforce liquidation in only two ways: the entrepreneur is unable to repay or refinance the project at time 1 , or the investor observes a verifiable state that enables liquidation.

The first step is to evaluate when monitoring is socially optimal. Let $q$ be the probability of success then the socially efficient decision is $L_{1} \geq q(X)+L_{2}$, which is equivalent to liquidating if $q \leq\left(L_{1}-L_{2}\right) / X \equiv \theta^{*}$. The value of the firm under private information is $E_{\theta}\left[\max \left\{\theta X+L_{2}, L_{1}\right\}\right]$ and the value of the firm under public information is $E_{\pi}\left[\max \left\{\pi X+L_{2}, L_{1}\right\}\right]$. The social value of information is 


$$
\Delta_{F B}=E_{\theta}\left[\max \left\{\theta X+L_{2}, L_{1}\right\}\right]-E_{\pi}\left[\max \left\{\pi X+L_{2}, L_{1}\right\}\right] .
$$

Only if $\Delta_{F B} \geq c$, monitoring is socially efficient; otherwise it is inefficient. In the following it is assumed that it is socially optimal to monitor, i.e. $\Delta_{F B} \geq c$.

Now, the entrepreneur has the choice to use long-term bank debt with the notional principal of $D_{2}$ (receivable in t=2), with $D_{2} \geq I>L_{1}$ from a single investor ('bank'). Without covenants the value of debt is $p D_{2}+(1-p) L_{2}$ and the bank has no incentive to monitor. Debt with covenants empowers the bank to enforce early repayment when the covenants are based on verifiable information, like financial ratios. To be valuable in the contract, covenants must add information that is more valuable than the public signal.

Assume that the verifiable signal $\varphi$ enables the investor to observe the unverifiable signal $\theta$ at no additional cost. Consequently, the bank can prove that $\varphi_{1}$, i.e. the bad state or covenant breach, has occurred. In case $\varphi_{1}$ is observed the bank can call the loan. But in order to be able to observe the signal $\varphi_{1}$ the bank has to constantly monitor the borrower. Applying the same logic to the value of monitoring as for the socially optimal situation, the bank will only monitor if $\Delta_{C V} \geq c$. The minimum value of monitoring $\Delta_{C V}^{*}$ where the bank is just willing to lend and monitor relates to the notional principal $D_{2}^{C V *}$. If $c \leq \Delta_{C V}^{*}$, i.e. the bank has an incentive to monitor and $X+L_{2} \geq$ $D_{2}^{C V *}$, i.e. the loan is feasible, long-term debt with covenants achieves monitoring, which is desirable when monitoring is socially optimal.

In contrast to the alternative to use long-term debt with covenants the entrepreneur also has the possibility to finance the project by issuing short-term debt. The bank invests $I$ for the payment of $D_{1}$ at $\mathrm{t}=1$. However, at $\mathrm{t}=1$ the entrepreneur does not have any money to repay the bank so the bank has the choice to demand immediate repayment, which would mean liquidation and a value of $L_{1}$ for the bank, or to roll over the original face value $D_{1}$ for a repayment of $D_{2}$ in $\mathrm{t}=2$. The bank will decide to roll over when the expected value in $\mathrm{t}=2$ is larger than $L_{1}$. If $D_{2}$ is larger than the value of the 
firm in $\mathrm{t}=2$, i.e. $X+L_{2}$, then the firm cannot pay. The bank therefore liquidates when $L_{1}>q X+L_{2}$, or equivalently $q<\theta^{*}$.

The bank receives $\max \left\{q\left(D_{1}-L_{2}\right)+L_{2}, L_{1}\right\}$ and the value of additional information acquired through monitoring is

$$
\Delta_{S T}=E_{\theta}\left[\max \left\{\theta\left(D_{1}-L_{2}\right)+L_{2}, L_{1}\right\}\right]-E_{\pi}\left[\max \left\{\pi\left(D_{1}-L_{2}\right)+L_{2}, L_{1}\right\}\right]
$$

and the bank only monitors if $\Delta_{S T} \geq c$. The maximum $\Delta_{S T}^{M a x}$ can be expressed as $\left(\pi_{1}-\theta_{1}\right)\left(L_{1}-L_{2}\right) / 2 \pi_{1}$. If $\Delta_{S T}^{M a x}$ is smaller than the monitoring cost $c$, short-term debt cannot achieve socially optimal monitoring. The equation for $\Delta_{S T}^{M a x}$ shows that the social optimality of short-term debt depends on the difference between the public and the private signal $\left(\pi_{1}-\theta_{1}\right)$. The smaller the difference the lower the benefits derived from monitoring for the bank. Similarly, the smaller the difference between liquidating today and liquidating tomorrow $\left(L_{1}-L_{2}\right)$ the less the gain from early liquidation and the lower the benefits of monitoring for the bank. Lastly, the higher the probability of success given the bad public signal, $\pi_{1}$, the lower the maximum value of monitoring. The signal $\pi_{1}$ is also negatively related to the optimal face value of debt, meaning that the higher $\pi_{1}$ the lower the optimal face value of debt.

To sum up the findings of the model, RAJAN/WINTON (1995) demonstrate that there are situations where short-term loans do not incentivize the bank to monitor even when monitoring is socially beneficial. The comparison of the two forms of financing show that the choice for monitoring depends upon the degree of information asymmetry. If private monitoring yields a large value as compared to publicly available information, like in the case of small businesses, short-term loans may already incentivize the bank to monitor. If more public information is available, but monitoring is still valuable, long-term loans with covenants are preferable. In line with this, medium sized firms predominantly use this sort of debt financing. When public information is widely available, as is the case for public firms, private monitoring does not yield sufficient value and the firm can be funded on a short-term basis, like commercial paper. 
RAJAN/WINTON (1995) also show that in many jurisdictions, among others Germany, lenders have the right to call the loan when the economic situation of the borrower has worsened 'significantly'. ${ }^{156}$ This formulation of the law leaves considerable scope for interpretation. Consequently, lenders demand maintenance financial covenants to reduce the uncertainty of court ruling because they contractually specify the point at which the economic situation of the borrower has worsened 'significantly'.

DIAMOND (1993) provides another perspective on the choice of short-term versus long-term debt, especially for LBOs where there is no external equity and a simultaneous selection of an entire debt package by an insider takes place ${ }^{157}$. The model predicts that the fraction of long-term debt is positively related to control rents, which is the portion of the return that only accrues to the controlling party. ${ }^{158}$ Assuming that the control rents are expressed in future increases of cash flows implies that borrowing more heavily on future cash flows is related to a higher share of long-term debt in the capital structure. KAPLAN/STEIN (1993) use a sample of 124 large buyouts completed between 1980 and 1989 to show that more debt in relation to the current EBITDA is related to a lower share of short-term debt. Furthermore, the model shows that it is optimal when short-term debt is senior to long-term debt, which was also observed by KAPLAN/STEIN (1993) for LBOs.

Another important implication of the model constitutes the contingency of debt ${ }^{159}$ dominates non-contingent debt. To sum up the findings of DIAMOND (1993), the optimal debt structure for LBOs is a combination of senior short- and junior long-term debt, both debt components being contingent on certain control rights of the lenders, like e.g. covenants.

\footnotetext{
${ }^{156} \S 490$ Abs. 1 BGB.

${ }^{157}$ This is not entirely true as the PEG typically chooses the debt structure and not the manager.

${ }^{158}$ Diamond (1993), p. 342.

${ }^{159}$ Diamond (1993) uses a call provision as the contingency, but the argument may also be applied to covenants.
} 


\subsubsection{Additional Functions of Financial Covenants}

TIROLE (2006) describes an indirect effect of financial covenants on the effort of the entrepreneur: as the loss in control, i.e. also of control rents, is a significant threat, financial covenants motivate the entrepreneur to perform well. ${ }^{160}$ A related argument is the debt covenant hypothesis. ${ }^{161}$ The hypothesis states that financial covenants provide incentives for the entrepreneur to engage in earnings management in order to avoid covenant breaches. ${ }^{162}$ DICHEV/SKINNER (2002) found empirical evidence supporting the debt covenant hypothesis.

Additionally, ROBERTS/SUFI (2009) find that financial covenants are not placed into private debt agreements to reduce the probability of renegotiations, but to influence the outcome of renegotiations by allocating bargaining power to the equity and debt parties.

\subsubsection{Excursus: Signaling Theory of Financial Covenants}

While the agency theory of covenants explains how covenants reduce agency problems ex post (i.e. moral hazard problems), the signaling theory relates to alleviating adverse selection problems ex ante ${ }^{163}$. It tries to explain the empirical observation that covenants are relatively tight and often in violation during the life of the loan. ${ }^{164}$

The ex ante information asymmetry between lenders and borrowers may lead to adverse selection problems. The idea is that the choice of covenants might serve as a signal for the quality of the borrower. The theoretic thinking behind this idea is based on the early theoretic work by CHAN/KANATAS (1985) and BESANKO/THAKOR (1987) on collateral requirements and more recently by GÂRLEANU/ZWIEBEL (2009) and DESSEIN (2005) on contract design and the allocation of control rights, i.e. covenants.

\footnotetext{
${ }^{160}$ Cf. Tirole (2006), p. 394.

${ }^{161}$ Cf. Watts/Zimmerman (1990), p. 139.

${ }^{162}$ Cf. Dechow/Ge/Schrand (2009), p. 83.

${ }^{163}$ Cf. Akerlof (1970).

${ }^{164}$ Cf. Chava/Roberts (2007).
} 
The underlying concept is that borrowers, i.e. shareholders, have better information concerning the future business prospects. To secure financing and reduce interest, the borrower will convey private information on expected positive future performance by accepting tight covenants. Additionally, borrowers have knowledge about the cost of covenant violations. If violation costs are perceived to be low (e.g., if the borrower knows that the lender does not have a significant incentive to impose severe restrictions on violations, or it is too costly to renegotiate with a dispersed lender base, like is the case for many syndicated loans). Lenders support this signaling behavior by charging lower spreads and for borrowers that choose tight covenants and penalizing poorly performing borrowers upon covenant violation.

GÂRLEANU/ZWIEBEL (2009), following the Grossman-Hart-Moore property rights given contractual incompleteness, consider the effect of information asymmetry in the design of debt covenants. ${ }^{165}$ They assume that shareholders are better informed about ex post wealth transfers from lenders to shareholders. The lender anticipates this potential ex post wealth transfer. Following their line of argument, the simple adverse selection problem leads to the allocation of greater ex ante decision rights, i.e. stricter covenants, to the uninformed party, i.e. the lender, than would follow under symmetric information. In subsequent possible covenant breaches the lender gives up this excessive restrictiveness, waives the breach and loosens the covenants although he has the right to call the loan. ${ }^{166}$

The theoretical background of signaling theory of Covenants is based on the fact that covenants are, in general, regularly re-negotiated. ${ }^{167}$ The less information about the future development of the company and hence future performance indicators is available the tighter covenants are initially set. ${ }^{168}$ Covenants are then re-adjusted to include

\footnotetext{
${ }^{165}$ In line with Gârleanu/Zwiebel (2009), Sridhar/Magee (1996) consider the effect of asymmetric information in the design of debt covenants. However, the authors' focus lies on the information content and the scope of misrepresentations. Additionally, Dessein (2005) considers the assignment of control rights/covenants under asymmetric information, not applied to lenders and borrowers, but to a contract between an entrepreneur and a venture capitalist.

${ }^{166}$ Cf. Gârleanu/Zwiebel (2009) p. 25.

${ }^{167}$ Cf. Berlin/Mester (1992), p. 96.

${ }^{168}$ Cf. Chava/Roberts (2008), p. 13, Gârleanu/Zwiebel (2009), p. 2.
} 
more precise and recent information. However, covenants are routinely relaxed but virtually never strengthened. ${ }^{169}$ As restrictive contracts are believed to come with lower cost of debt, ${ }^{170}$ borrowers have an additional incentive to negotiate tight constraints ex ante.

However, signaling strategies by the borrower go further than just offering control rights. The quality of the firm may also be revealed by an investment of the entrepreneur in the business and the existence of low-risk debt. ${ }^{171}$ Also, the use of short-term debt instead of long-term debt may be used as a signal of good credit quality to lenders. ${ }^{172}$ Fundamental literature, on which signaling theory of Covenants is based on, primarily deals with collateral. The mental leap to covenants is performed by accepting covenants as, at least partly, substitution to collateral. So, BESANKO/THAKOR (1987) observe:

'... Low risk borrowers choose contracts with low interest rates and high collateral requirements whereas high-risk borrowers chose contracts with high interest rates and low collateral requirements ..., ${ }^{, 73}$

\subsection{Summary}

This section introduces a theoretical dichotomous ${ }^{174}$ taxonomy for the rationale of covenants that is in line with economic considerations following TIROLE (2006) and focuses on the relationship between equity- and debt holders. The first economic rationale for covenants, the 'conflict view', has its foundation in the principal agent theory and explains the usage of action-restricting covenants. The resulting agency theory of covenants states that rational debt holders anticipate the potential for opportunistic behavior by the shareholder and will therefore price the debt accordingly. This reduces

\footnotetext{
${ }^{169}$ Cf. Gârleanu/Zwiebel (2009), p. 2.

${ }^{170}$ Cf. Besanko/Thakor (1987), p. 672.

${ }^{171}$ Cf. Leland/Pyle (1977), p. 372.

${ }^{172}$ Cf. Diamond (1991), p. 408.

${ }^{173}$ Cf. Besanko/Thakor (1987), p. 672.

${ }^{174}$ Several other studies classify covenants according to their concrete functions. However, these functions can be aggregated to two economic broader categories.
} 
the value of equity. By limiting their action spectrum through action-restricting covenants, equity holders benefit from reduced agency costs of debt. However, the writing of covenants involves enforcement costs and reduced profitability due to the limitation of management's decision spectrum. ${ }^{175}$

The second economic rationale for covenants, the 'control view', is based on the financial contracting theory and explains the usage of financial covenants as well as the combination of financial and action-restricting covenants in credit agreements. In a world with incomplete contracts, state contingent control dominates unilateral, i.e. sole borrower or lender, control. The contingency depends upon a signal that is transmitted through a device that is sufficiently correlated with the true state of the firm. Financial covenants are the device that transmits this signal. If the signal is positive, i.e. the financial covenant is not violated, the borrower maintains control. By contrast, if the signal is negative, i.e. the financial covenant is breached, the lender receives control.

Lenders could achieve the same result by lending only short-term and renew the contract if the state of the firm is not promising to repay in the next period. However, short-term loans provide lenders with too much power, leading to excessive liquidation. ${ }^{176}$ Covenants are therefore written in the contract to ensure that lenders receive control in 'right' situations. RAJAN/WINTON (1995) demonstrate that especially for medium sized firms with remaining information asymmetries the value of the firm is optimized when using long-term debt including covenants as opposed to short-term debt. DIAMOND (1993) demonstrates that it is optimal for LBOs to use a long-term debt structure with covenants which was supported empirically by KAPLAN/STEIN (1993).

\footnotetext{
${ }^{175}$ Another way to reduce the agency problems is through the use of convertible securities.

${ }^{176}$ Cf. Rajan/Winton (1995), p. 1134.
} 


\section{Classification and Types of Covenants}

\subsection{Introductory Remarks}

The indenture - also known as credit agreement - is the legally binding document between creditors and the issuing firm. It includes all contractual rights and obligations of the parties, including covenants. ${ }^{177} \mathrm{~A}$ violation of the terms leads to an 'event of default', which gives lenders the right to redeem the outstanding principal. A covenant breach is known as technical default, leading to the same consequences as a formal default on debt service. ${ }^{178}$

The following section is organized as follows: first, action-restricting covenants will be linked to their theoretic rationale and usage in private and public debt agreements as documented in existing literature. The second part of the section analyzes the types, construction and measure of restrictiveness of financial covenants. The third part discusses covenants in leveraged buyouts as a subcategory of private debt and presents selected empirical evidence. Fourth, an overview of covenants in debt agreements is presented.

The dichotomy of economic rationales for covenants in section 3 (the conflict and control view) provides the framework for structuring the types of covenants included in debt agreements. Types of covenants that have their theoretical foundation in the agency conflict between debt and equity holders are action-restricting covenants, whereas types of covenants that have their theoretical foundation in control rights theory are financial covenants.

\subsection{The Conflict View - Action-restricting Covenants}

SMITH/WARNER (1979) are the first to provide an overview on types of actionrestricting covenants to mitigate the conflict between debt and equity holders. They formulate the costly contracting hypothesis derived from the theoretical foundations built in JENSEN/MECKLING (1976). This hypothesis assumes that external markets

\footnotetext{
${ }^{177}$ Cf. Malitz (1994), p. 9.

${ }^{178}$ Cf. Beneish/Press (1993), p. 235.
} 
- deviating from the irrelevance hypothesis from MODIGLIANI/MILLER (1958) are insufficient to induce the shareholder to maximize firm value. ${ }^{179}$ The costly contracting hypothesis states that financial contracts bear costs and shareholders compare the benefits and costs of each contractual feature and decide whether to include it or not. Consequently, there exists a unique optimal constellation of financial contracts, here covenants, for each debt contract which maximizes the value of the firm. ${ }^{180}$

\subsubsection{Covenants limiting Asset Substitution}

As mentioned in the theoretic section 3.2.1.1, the convex claim of shareholders induces increased risk investments, expropriating debt holders with their concave claim. To reduce the potential for ex post wealth transfer and value reduction, shareholders might voluntarily limit their investment policy. For instance, covenants might prohibit explicit investments, restrict mergers and acquisitions and limit the disposition of existing assets (which might then be substituted with riskier assets). ${ }^{181}$

For public debt, BILLETT/KING/MAUER (2007) use the Fixed Investment Securities Database (FISD) and find that out of 15,504 US public debt issues between 1985 and 2003 4.2\% contain explicit investment policy restrictions, while 64.6\% of the issues contain merger restrictions and $64.5 \%$ include asset sale covenants. For private debt, BRADLEY/ROBERTS (2004) show that $62.5 \%$ of 8,553 US private debt issues contain covenants, which mandate early retirement of the loan, conditional on an asset sale, so called 'asset sweeps'. Sweeps are stated as percentages, corresponding to the fraction of the loan that has to be repaid in case of violating the asset sale restriction. For instance, a $30.0 \%$ asset sweep forces a company to repay $30.0 \%$ of the loan principal if it sells more than a specified amount of assets. Existing empirical literature shows that explicit covenants on the issuer's investment policy are very rare. The low share of - or the missing data of - covenants on investment policies may be explained by the difficulty to write explicit restrictions on investments.

\footnotetext{
${ }^{179}$ A further assumption of the costly contracting hypothesis is that debt increases firm value and is therefore utilized in the capital structure.

${ }^{180}$ Cf. Smith/Warner (1979), p. 121.

${ }^{181}$ Cf. Smith/Warner (1979), p. 128, Tirole (2006), p. 85.
} 
While debt holders might reduce these actions by demanding a shorter maturity of the loan, another additional measure is a covenant which limits excessive investing by limiting total investments to a certain amount. This so-called capital expenditure (capex) covenant has not been subject to extensive academic literature. Only recently, NINI/SMITH/SUFI (2007) focused on this area of research and found that 31.9\% of 3,720 private debt agreements of US corporations contain explicit restrictions of capital expenditures. Practitioners often classify the capex covenant as financial covenant. Hence, it is part of the section that regulates financial covenants in the credit agreement. However, as this covenant restricts asset substitution and limits a largely discretionary item, i.e. capital expenditure, it could also be classified as action-restricting covenant. DEMERJIAN (2010) implicitly follows this logic as he does not include capex covenants in their analysis on the universe of financial covenants. NINI/SMITH/SUFI (2007) explicitly separate capex covenants from financial covenants and classify them as action-restricting covenants.

Indirectly, financial covenants may limit the potential for asset substitution as they demand a specified operational performance (e.g. EBITDA or operating cash flow), which can only be achieved if the firm invests in assets. For example, LELAND (1994) demonstrates that net worth covenants reduce the incentive for equity holders to increase the risk of the firm by the means of asset substitution. ${ }^{182}$

\subsubsection{Covenants limiting Underinvestment}

The underinvestment problem, described in section 3.2.1.2, induces the shareholder to invest in projects which he expects to return sufficient cash flow to satisfy debt holders and leave a positive residual claim for him. The higher the share of debt, the more selective the shareholder will be as the debt holder will reap most of the cash flows. This behavior of the shareholder reduces the investment opportunities and, consequently, the value of the firm. ${ }^{183}$ Defining the capital budgeting process ex ante is impossible or

\footnotetext{
${ }^{182}$ Cf. Leland (1994), p. 1216.

${ }^{183}$ Cf. De Matos (2001), p. 74f.
} 
at least extremely costly. ${ }^{184}$ In order to control for this problem, MYERS (1977) suggests, among others, to include covenants that restrict payments - dividend and share repurchases $^{185}$ - to shareholders. The idea behind restricting dividends is that residual cash flows (after paying the limit of dividends) have to be invested in 'something'. ${ }^{186}$

Covenants that restrict payments to shareholders are well-covered in the existing literature. There are two studies that extensively analyze action-restricting covenants in public debt, namely BILLETT/KING/MAUER (2007) or NASH/NETTER/POULSEN (2003). In their sample of 15,504 US debt issues, $27.0 \%$ contain dividend and $22.6 \%$ share repurchase restrictions being highly pair-wise correlated (0.72). NASH/NETTER/POULSEN (2003) document that 19.9\% of 496 US bonds, originated between 1989 and 1996, contain dividend restrictions. In contrast to public debt, BRADLEY/ROBERTS (2004) show that US private debt contracts contain a significantly higher share of dividend restrictions in form of cash sweeps (85.1\%). Cash sweeps are stated as percentages and specify the allocation of excess cash flow. For example, a cash sweep may constitute that $50.0 \%$ of the excess cash flow is used to repay debt. This clause creates an incentive for the equity holder to invest in projects rather than maximize excess cash flow.

Additionally, this data supports the argument that private debt covenants are more effective and hence more valuable in private versus public debt. ${ }^{187}$ The reason is that bank debt contracts, i.e. private debt contracts, are easier to renegotiate and are thus less costly than covenants in public debt. ${ }^{188}$

However, covenants that restrict payments to shareholders do not eliminate the agency costs that arise from the underinvestment incentives because the dividend restrictions

\footnotetext{
${ }^{184}$ Cf. Myers (1977), p. 17.

${ }^{185}$ Tirole (2006) also mentions 'affiliated transactions', i.e. transactions where a firm engages in lossmaking transactions with other companies that are also owned by the shareholders. Cf. Tirole (2006), p. 85.

${ }^{186}$ Cf. Myers (1977), p. 19a but also Smith/Warner (1979), p. $132 \mathrm{f}$.

${ }^{187}$ Cf. Bradley/Roberts (2004), p. 13.

${ }^{188}$ The rationale behind the lower cost of renegotiation is based on the argument that bank debt is held by a lower number of parties as compared to public debt. Cf. Bradley/Roberts (2004), p. 13.
} 
might force the firm to invest in assets with negative NPV (i), and in bad economic states the available cash flow after debt service might be fully paid out although it would make sense to invest money to save the firm (ii). ${ }^{189}$ Since the risk for underinvestment is positively related to leverage, covenants that limit leverage may reduce this conflict of interest. ${ }^{190}$ Consequently, financial covenants indirectly attenuate the agency cost of debt, caused by underinvestment.

\subsubsection{Covenants limiting Claim Dilution}

If debt holders price the debt under the assumption that no additional debt will be issued ex post, shareholders expropriate debt holders by issuing debt with equal or higher seniority. Following the ex post issuance original debt holders are exposed to higher risk while still receiving ex ante lower risk interest. FAMA/MILLER (1972) label the type of covenants that limit claim dilution 'me-first' rules as they assert the debt holder that he will remain in the ex ante assumed position in the claim hierarchy. ${ }^{191}$ Intuitively, restricting the issuance of additional debt is a simple solution to the claim dilution problem. However, claim dilution may arise if the government acquires claims against the firm. Therefore, debt holders demand covenants that force the company to pay taxes, pension contributions and conform to environmental requirements. Debt holders may also demand that a covenant prevents the borrower from pledging assets with additional claims. This kind of clause is called negative pledge clause. Lastly, debt holders may demand ex ante that off-balance sheet financing, like a sale-and-lease-back transaction, is limited. ${ }^{192}$

Covenants restricting claim dilutions are well covered by academic research in the US, both in public as well as private debt markets. Regarding public debt contracts, BILLETT/KING/MAUER (2007) document that $44.3 \%$ of debt agreements include nega-

\footnotetext{
${ }^{189}$ Cf. Myers (1977), p. 19b.

${ }^{190}$ Cf. Nash/Netter/Poulsen (2003), p. 203.

${ }^{191}$ Cf. Fama/Miller (1972) cited in Nash/Netter/Poulsen (2003), p. 204.

${ }^{192}$ Cf. Billett/King/Mauer (2007), p. 706.
} 
tive pledge clauses. ${ }^{193}$ Of these, $29.2 \%$ utilize sale-and-lease-back restrictions, while senior as well as subordinated debt provisions are included less frequently, i.e. in $1.4 \%$ and $6.0 \%$ of the indentures respectively. NASH/NETTER/POULSEN (2003) find that $67.5 \%$ of public debt agreements contain negative pledge clauses, $40.1 \%$ include saleand-lease-back provisions and 24.2\% include additional debt limitations. Private debt contracts again contain claim dilution covenants more frequently: BRADLEY/ROBERTS (2004) find that $76.5 \%$ of private debt agreements contain restrictions on additional secured debt and $46.2 \%$ contain restrictions on additional debt. Note that covenants limiting seniority of governmental claims are standardized including covenants that enforce the issuer to pay taxes, conform to the law and to environmental provisions etc.

As seen in asset substitution and underinvestment problems, financial covenants may indirectly reduce conflicts by imposing limits to leverage and cash flow measures. This attenuating effect of financial covenants also holds true for claim dilution: senior as well as subordinated lenders impose limits on financial ratios that limit the possibility for the borrower to take on additional debt. Having explained the types and usage of action-restricting covenants the next section introduces financial covenants.

\subsection{The Control View - Financial Covenants}

Control rights theory explains the existence of signals that reveal the state of the firm to debt holders and the contingent control of the firm. Financial covenants are an important instrument that transmits this signal. ${ }^{194}$ If a financial covenant is breached, the issuer is in technical default and the debt holder receives control rights. If no financial covenant is in violation the shareholder remains in control and is able to extract private benefits. ${ }^{195}$

\footnotetext{
${ }^{193}$ Billett/King/Mauer (2007) call the negative pledge clauses secured debt covenant, which typically specifies 'that the issuer cannot issue secured debt unless it secures the existing issue on a pari passu basis'. Cf. Billett/King/Mauer (2007), p. 706.

${ }^{194}$ Others are for instance the payment of interest and redemption.

${ }^{195}$ See 3.3.2.
} 


\subsubsection{Types of Financial Covenants}

Financial covenants constitute limits on the level of accounting figures, expressed in both relative and absolute value. ${ }^{196}$ Types of financial covenants are coverage, current, leverage ratios as well as gearing and net worth. Coverage covenants constitute limits on the relationship between an operating performance indicator and the cash flow burden of debt, like EBITDA to interest (EBITDA/I). Current covenants restrict the liquidity of a borrower, limiting the relation of current assets to current liabilities. Leverage covenants constitute upper limits on the multiple of a debt indicator to an operating performance indicator, like debt to EBITDA (D/EBITDA). The gearing covenant limits the share of debt in the financing structure by limiting the ratio of debt to assets or equity. Net worth ratios are lower boundaries for the difference of assets and liabilities of a borrower. ${ }^{197}$

Before describing the utilization of financial covenants in private and public credit agreements, it is essential to mention a fundamental difference between financial covenants in public and private credit agreements: while public debt indentures contain incurrence covenants, private debt agreements include maintenance covenants. ${ }^{198}$ The essential difference between these two categories of financial covenants is the testing condition.

The testing of incurrence covenants is contingent on a certain pre-defined occurrence or action of the borrower. The set of typical testing events include actions that might extract wealth from debt holders, like an acquisition, a debt issuance or dividend payment. This type of financial covenant is integrated in public debt agreements to allow wealth decreasing actions as long as certain financial ratios are fulfilled. Only if the borrower breaches the financial covenants and still pursues the 'prohibited' action, the credit agreement is violated. ${ }^{199}$ Consequently, incurrence financial covenants cannot be explained by control rights theory but by agency theoretic arguments. The existence of

\footnotetext{
${ }^{196}$ Cf. Roberts/Sufi (2009), p. 165.

${ }^{197}$ For a detailed description see Demerjian (2010).

${ }^{198}$ Cf. Polenberg/Lukatsky/Gupte (2010), p. 16.

${ }^{199}$ Cf. Eilers/Koffka/Mackensen (2009), p. 319, and Begley/Chamberlain (2006), p. $7 f$.
} 
incurrence covenants in public debt is the result of high renegotiation costs, as the structure of debt holders is diffuse and widespread.

As a violation of incurrence covenants can be easily avoided, they have a lower value for debt holders in comparison to maintenance covenants. Based on this lower importance, incurrence financial covenants is not the focus of academic research. One of the few exceptions is from BEGLEY/CHAMBERLAIN (2006). They observe a sharp decline in the use of financial covenants in public debt in the period from 1975 to 2002. While in the period of 1975 to 1979 46.7\% of public debt contracts contained an incurrence covenant either restricting dividend payments or issuing debt, only $10.0 \%$ did so in the period of 1999 to 2002.

By contrast, maintenance covenants are typically included in private debt agreements. This type of financial covenant is tested on an ongoing basis and has to be met over the term of the loan, independent of any wealth-shifting attempts of the borrower. Maintenance covenants are expected to increase the wealth for the lender in comparison to incurrence covenants and should, therefore, yield lower probabilities of default and higher recovery rates in case of payment default on average. Supporting this notion, S\&P estimates that loans with incurrence covenants have $8.0 \%$ to $14.0 \%$ lower recovery rates. ${ }^{200}$ Leveraged loans traditionally incorporate maintenance covenants. However, in overheated credit markets leveraged loans might loosen maintenance covenants or even switch to incurrence covenants. The covenant structure including incurrence covenants only is known as 'covenant-lite' deals. ${ }^{201}$

When analyzing financial covenants researchers focus on private debt agreements. As KAHAN/TUCKMAN (1993) note, technical defaults based on financial covenants occur almost exclusively in private debt contracts - they did not find any financial covenants in the public debt agreements -, which contain relatively more and tighter covenants when compared to public debt issues. ${ }^{202}$ Lower renegotiation costs due to

\footnotetext{
${ }^{200}$ Cf. Lai/Bavaria (2007), p. 4.

${ }^{201}$ Cf. Lai/Bavaria (2007), p. 8.

${ }^{202}$ Cf. Kahan/Tuckman (1993).
} 
the concentration of lenders and the active monitoring by private lenders lead to reduced renegotiation costs compared to public issues. ${ }^{203}$ BOLTON/SCHARFSTEIN (1995) laid the theoretic foundations for negotiations in debt contracts and the optimal number of creditors.

The most recent papers on financial covenants predominantly use Reuter's LPC Dealscan, a database of private and public lending agreements in the US. DEMERJIAN (2010) provides the broadest and most recent analysis on the selection of financial covenants in private debt agreements. The paper groups financial covenant ratios into five classes and reports the use in 16,364 US loan agreements between 1987-2006 ${ }^{204}$. The observed covenant frequencies are reported in Table 2.

\begin{tabular}{|llc|}
\hline Financial covenant category & \multicolumn{1}{c}{ Definiton } & Frequency \\
\hline Coverage & Operating performance indicator / cash flow burden from debt & $62 \%$ \\
Current & Current assets / current liabilities & $10 \%$ \\
Leverage & Debt indicator / operating performance indicator & $40 \%$ \\
Gearing & Debt indicator / assets or equity & $30 \%$ \\
Net worth & Assets - liabilities & $39 \%$ \\
& & \\
Covenants per deal & & 1.8 \\
\hline
\end{tabular}

Table 2: $\quad$ Types of financial covenants in private credit agreements Source: $\quad$ DEMERJIAN (2007), p. $34 .^{205}$

DEMERJIAN (2010) predicts and finds that borrowers with positive earnings, high profitability and low earnings volatility, are likely to contain covenants measured with earnings, predominantly coverage and leverage covenants. Borrowers with losses, low profitability and highly volatile earnings are likely to include net worth covenants.

CHAVA/ROBERTS (2008) also provide a broad overview of financial covenant restrictions in private debt agreements in the US. According to their dataset, covering

\footnotetext{
${ }^{203}$ See the works of Diamond (1991) and Rajan (1992).

${ }^{204}$ In order to eliminate any confusion among private-equity-academics and practitioners this thesis labels Demerjian's Debt to Cash Flow ratio as Leverage ratio and the Debt to Equity ratio as Gearing. This is in line with the studies of Axelson, et al. (2010) and Demiroglu/James (2010b).

${ }^{205}$ Demerjian (2010) is the revised version of Demerjian (2007). However, Demerjian (2010) does not report the inclusion of the individual types of financial covenants anymore. Therefore, the source for Table 2 is from Demerjian (2007).
} 
6,386 US loan packages, the most frequent financial covenants included in private debt agreements are leverage ratios, i.e. maximum D/EBITDA, Net Worth and Coverage ratios. Aggregating the frequency of the individual financial covenants to groups, results in similar results compared to the study of DEMERJIAN (2010). As most important studies, like BRADLEY/ROBERTS (2004) or DICHEV/SKINNER (2002) are based on Dealscan data, their findings on the frequency of financial covenants are in line.

The classification of covenants in this thesis is as well based on Dealscan and discussions with industry experts. The analysis considers the following seven financial covenants $^{206}$ : (1) Debt to EBITDA (D/EBITDA), (2) EBITDA to Interest (EBITDA/I), (3) Unlevered Cash Flow to Debt Service (CashFlowCoverage), (4) Capex, (5) Net Worth, (6) Debt to Equity (D/E) and (7) Current Ratio covenants.

\subsubsection{Construction}

Before explaining the measurement of financial covenants' restrictiveness it is essential to understand how financial covenants are constructed. The credit agreement records the thresholds of the financial covenants, e.g. D/EBITDA, and the testing dates of the ratio (see Figure 11). For instance, the credit agreement shown in Figure 11 constitutes that D/EBITDA must not exceed 7.2x at 31 ${ }^{\text {st }}$ December 2006 (this section will continue with this numerical example for illustrative purposes). However, it is not clear how this threshold is derived and what determines the exact level.

\footnotetext{
${ }^{206}$ For reasons of completeness the capex covenant is included in the analysis.
} 


\section{FINANCIAL COVENANTS}

\subsection{Financial condition}

The Company shall ensure that:

(a) the ratio of Consolidated Cash Flow to Net Debt Service will not be less than 1:1 for any Relevant Period.

(b) the ratio of Total Net Borrowings on each Relevant Date set out in the table below to Consolidated EBITDA for the Relevant Period ending on that Relevant Date will not exceed the ratio set out in the relevant column in the table below opposite that Relevant Date;

(c) the ratio of Consolidated EBITDA to Consolidated Net Finance Charges for each Relevant Period ending on a Relevant Date set out in the table below will not be less than the ratio set out in the relevant column in the table below opposite that Relevant Date;

\begin{tabular}{|c|c|c|}
\hline Relevant Date & Total Debt to EBITDA & $\begin{array}{c}\text { EBITDA to Finance } \\
\text { Charges }\end{array}$ \\
\hline 30 June 2006 & $7.60: 1$ & $1.90: 1$ \\
30 September 2006 & $7.50: 1$ & $1.90: 1$ \\
31 December 2006 & $7.20: 1$ & $2.00: 1$ \\
\hline 31 March 2007 & $7.10: 1$ & $2.00: 1$ \\
30 June 2007 & $6.80: 1$ & $2.00: 1$ \\
30 September 2007 & $6.70: 1$ & $2.00: 1$ \\
31 December 2007 & $6.50: 1$ & $2.00: 1$ \\
\hline
\end{tabular}

Figure 11: Exemplary excerpt of financial covenants in a credit agreement Source: $\quad$ Typical credit agreement

The covenant threshold is the result of an extensive negotiation process between the lead arranger and the private equity group. In the beginning of the process the PE group identifies a target company, which it plans to bid on and, therefore, sends a business plan to potential lead arranging banks. Based on the provided information, lead arrangers decide whether to submit a term sheet to the sponsor. The term sheet typically includes estimates of the debt package including interest margins, debt package, maturity as well as types and restrictiveness of financial covenants. In the case that the sponsor agrees to the term sheet, the sponsor sends his detailed operational model ('sponsor case'), which includes the sponsor's estimate for EBITDA and un- 
levered cash flow ${ }^{207}$, to the lead arranging bank. ${ }^{208}$ The operational information and the lead arranger's own due diligence serve as the foundation to adjust the sponsor case to the lead arranger's assumed growth rates that are typically more conservative for EBITDA and unlevered free cash flow.

Based on the forecast, the lead arranging bank and the sponsor negotiate a debt package. The utilized debt instruments have defined repayment and interest schedules. The combination of the assumed operational forecast and the debt package constitutes the 'financing case', which is disclosed to potential syndication partners. The financing case contains explicit quarterly forecasts over at least five years for key credit statistics like, D/EBITDA, EBITDA/I and CashFlowCoverage. These forecasts of the key credit ratios constitute the basis for negotiating the thresholds of financial covenants.

To arrive at the threshold, the lead arranger and the private equity sponsor negotiate the distance between the projected financial ratio and the covenant threshold (see Figure 12 for a graphical illustration). Although the final threshold in the credit agreement is a ratio, the way the threshold is determined is derived from the negotiated and agreed-on EBITDA or cash flow forecast. The reason behind this is simple: EBITDA measures the operational performance which is determined by the effort of the management and the sponsor, while the forecast of debt, redemptions and interest payments are determined by banks and the sponsor. The distance between the EBITDA forecast and the implied EBITDA by the covenant threshold and the projected EBITDA is called the 'headroom'.

\footnotetext{
${ }^{207}$ Unlevered cash flow equals free cash flow before interest. It is identical to free cash flow for a $100 \%$ equity financed firm.

${ }^{208}$ For simplicity the author assumes exclusivity between the private equity sponsor and the lead arranging bank.
} 


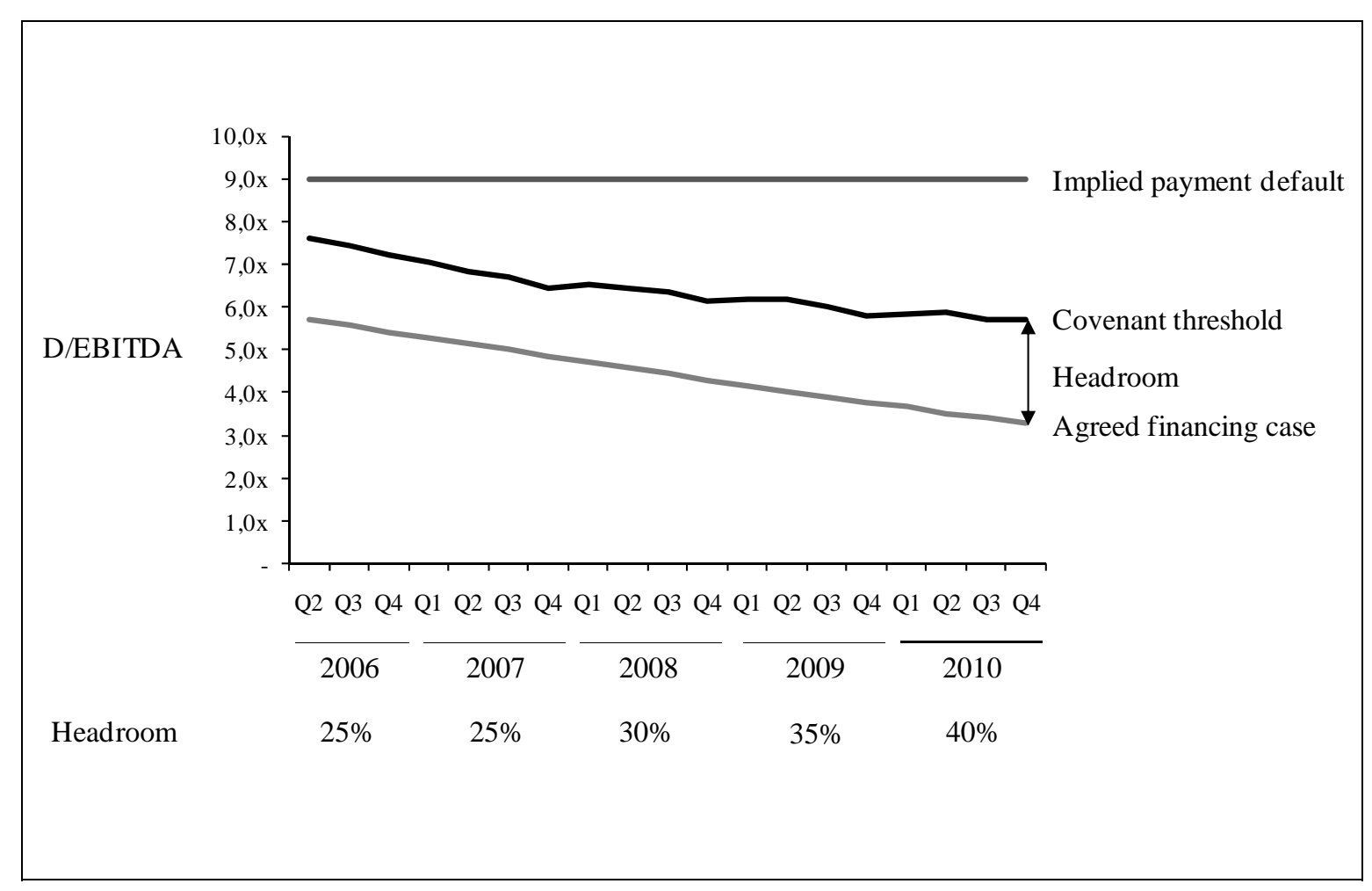

Figure 12: Conceptional covenant construction Source: $\quad$ Author

The numerical example in Table 3 shows how financial covenant thresholds are calculated, starting from the financial forecast, using the headroom as the critical component to determine the threshold (the example includes the calculation of senior and mezzanine covenants). The more restrictive the bank wants to set the covenant, the closer the covenant threshold is set to the agreed financing case, i.e. the lower the headroom. Negotiating the headroom reflects the relation between the private equity sponsor and the bank: banking relationship and reputational arguments may induce the bank to accept more headroom. 


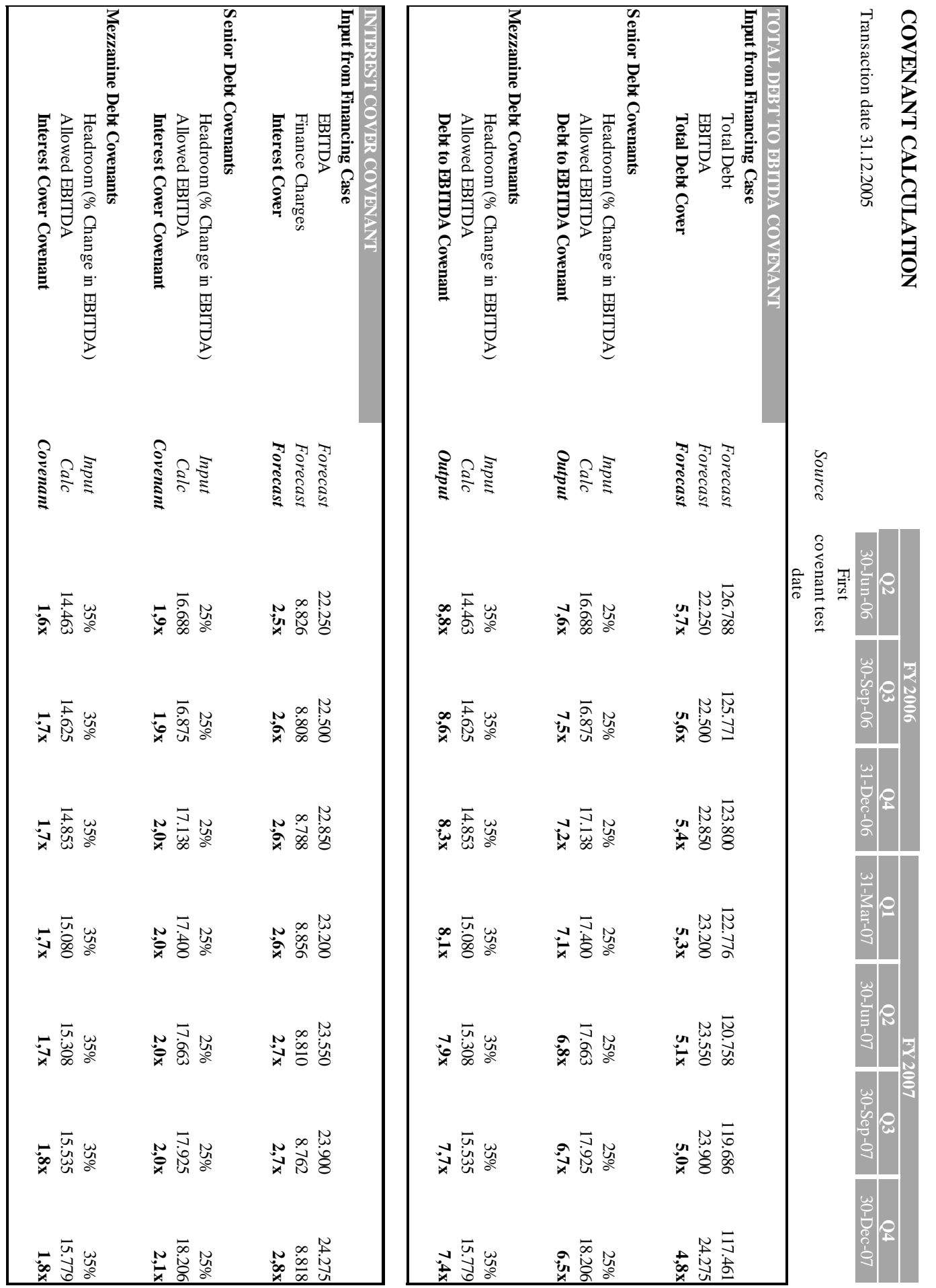

Table 3: $\quad$ Financial covenants in a credit agreement

Source: Author 
To ensure consistent calculation for different types of financial covenants, headrooms (HR) for the D/EBITDA, EBITDA and CashFlowCoverage covenant are defined as:

$$
\begin{aligned}
& H R_{D / E B I T D A}=-\left(\frac{E B I T D A_{C o v}}{E B I T D A_{F C}}\right)-1=-\left(\frac{\frac{N_{e t ~ d e b t} t_{F C}}{E I I T D F C}}{\frac{\operatorname{Netdebt}_{F C}}{E B I T D A_{C o v}}}\right)-1 . \\
& H R_{E B I T D A / I}=-\left(\frac{E B I T D A_{C o v}}{E B I T D A_{F C}}\right)-1=-\left(\frac{\frac{E B I T D A_{C o v}}{\text { Interest } F C}}{\frac{E B I T D A_{F C}}{\text { Interest } F C_{F C}}}\right)-1
\end{aligned}
$$

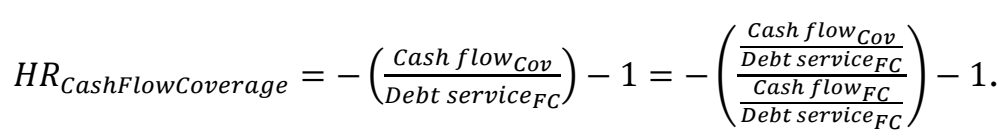

\subsubsection{Measure of Restrictiveness}

The prior section showed the technical process on how financial covenants are set. Measuring the restrictiveness of financial covenants is difficult. ${ }^{209}$ This explains why there is still no coherence in scholarly work and why researchers apply a wide variety of different measures. There are two common measures for restrictiveness in academic literature: the covenant threshold and the covenant slack.

One way to measure covenant restrictiveness is the covenant threshold. The threshold is the aggregated component of the projected credit ratio plus headroom, i.e. a cushion for the borrower at a certain point in time. In the example above, in Q4 2006 the projected D/EBITDA ratio in the financing case is 5.4x and the EBITDA headroom of $25.0 \%$ adds $1.8 \mathrm{x}$ to the ratio, resulting in a D/EBITDA covenant threshold of $7.2 \mathrm{x}$ in Q4 2006. Therefore, the threshold would be a good measure for restrictiveness if the projected D/EBITDA at the covenant testing date is available. Using thresholds as a measure of covenant restrictiveness without knowing the expected D/EBITDA ratio, does not indicate how close the threshold is set to the expected ratio, i.e. how endangered the company is to violate the covenant. For instance, firm A might have a D/EBITDA threshold of 6/1 with a current D/EBITDA ratio of 4/1, while firm B has a

\footnotetext{
${ }^{209}$ Begley (1990) analyzes different articles and their measures for restrictiveness. Cf. Begley (1990), p. 132.
} 
D/EBITDA threshold of 7/1 and a current D/EBITDA ratio of 6.5/1. Evidently, firm B is more in danger of violating a covenant, i.e. has a more restrictive D/EBITDA covenant, all else being equal. In order to address this concern, studies usually follow an indirect approach and control for all relevant financial risk variables at the right-hand side in a multiple regression analysis.

Alternatively, studies calculate the covenant slack (i.e. the distance to default) as a measure of financial covenant tightness. The covenant slack is defined as the difference between the covenant threshold and the expected future ratio at a defined point in time. The greater the slack the looser the covenant since the borrower's financial ratio can deteriorate by a larger amount before triggering a covenant violation. Since information on the expected performance of the borrower is hard to obtain, researchers generally calculate the actual slack. For instance, DICHEV/SKINNER (2002) calculate the difference between the covenant threshold and the actual reported ratio. Therefore, the actual slack is the result of two factors, i.e. the ex ante set covenant tightness and the ex post realized performance of the borrower. In the example, firm A would have a slack of 2/1 (6/1-4/1) and firm B of 0.5/1 (7/1-6.5/1) suggesting that firm B has a more restrictive D/EBITDA covenant. But one would not know whether this tight covenant is the result of a poor performance of firm B or a tight covenant setting at loan origination, or both. A further concern with the actual slack as a measure for restrictiveness is that the definition of the input variables for the covenant and the actual realized ratio may vary. To minimize these inaccuracies, most studies that calculate the actual slack use net worth and current ratio covenants that have relatively few adjustments. ${ }^{210}$ However, net worth and current ratio covenants are rarely used in LBOs. These concerns could be eliminated by calculating the slack as the difference between the D/EBITDA covenant threshold and the expected future D/EBITDA at the first testing date. ${ }^{211}$ Still, the slack is not a perfect apples-to-apples measure of covenant tightness in the cross-section. Comparing D/EBITDA covenant slack across different deals

\footnotetext{
${ }^{210}$ Cf. Dichev/Skinner (2002).

${ }^{211}$ Testing date is the point in time when financial ratios are calculated and compared to the financial covenant threshold in the credit agreement.
} 
might introduce measurement errors since the definition of the input parameters (i.e. debt and EBITDA) may vary across deals. ${ }^{212}$

Besides these indirect measures to assess the restrictiveness, the headroom constitutes the measure, which is directly negotiated ex ante between borrowers and lenders. The headroom eliminates the first problem of slack as it looks at the difference between two measures that are defined identically. Due to the underlying definitions which may not constitute the same restrictiveness in different transactions, comparing headrooms in the cross section could still be problematic. LAWLER (2007) describes private equity industry practices:

'... it is not unusual for the borrower to request changes to the definitions of EBITDA, indebtedness and the other definitions embedded in the financial covenants that far exceed the original definitions ... The result is that while the covenant numbers may appear to be tight, they have been loosened by the negotiations of the covenant definitions in the legal documents. ${ }^{213}$

This argument is valid for the cross-sectional analysis of the restrictiveness of headrooms, i.e. $20 \%$ headroom in one deal may be less restrictive than $20.0 \%$ headroom in another. To avoid this reduced comparability the LMA tries to standardize definitions used to calculate in credit agreements. As Mark Campbell, Head of Global Finance of Clifford Chance put it:

'... LMA covenants [definitions] define exactly what EBITDA is for the purposes of the document ... ' 214

While the final definitions in the individual credit agreements may differ from the LMA standard, LMA definitions are used as a starting point to negotiate the definitions of covenants. Over the course of the deal, definitions are possibly extended, depending on the negotiation between lead arranger and sponsor. In order to control for

\footnotetext{
${ }^{212}$ Cf. Lawler (2007), p. 11-12.

${ }^{213}$ Cf. Lawler (2007), p. 12.

${ }^{214}$ Cf. Clifford Chance (2007), p. 4.
} 
the difference in definitions in the cross-section one could measure the difference between the LMA EBITDA definition and the EBITDA definition in the credit agreement, by simply counting the add-backs to net income, which is derived from the national prevailing accounting method. ${ }^{215}$ Controlling for this deviation, headroom could be well used for cross-sectional analysis for deals with the same applicable accounting principles.

\subsubsection{Effectiveness of Financial Covenants}

For financial covenants to be effective, two conditions have to be met. First, lenders have to be well informed to detect covenant violation. Second, borrowers should not be able to fictitiously manipulate financial statements to comply with financial covenants. ${ }^{216}$

KAHAN/TUCKMAN (1993) analyzed informational covenants for public and private debt. They find that private debt agreements contain more extensive informational requirements, which leads to facilitated lender monitoring. Financial statements are required quarterly and in greater depth for private debt agreements, while lenders receive annual, consolidated financial statements for their bondholdings. Additionally, private debt agreements demand a quarterly certificate of compliance with covenants and a detailed calculation of financial ratios. Public debt certificates are provided annually without detailed background information. Also, issuers of private debt agreements have to notify all debt holders whereas bond issuers only need to inform a trustee who in turn decides upon the information of the bondholder. ${ }^{217}$

Besides informational covenants, financial covenants need limitations on accounting manipulation to be effective. There is a mature body of literature which argues that financial covenants provide incentives for earnings management to satisfy financial covenants. For example, DICHEV/SKINNER (2002) found confirming evidence for this so called 'debt covenant hypothesis'. This motivates the existence of a further

\footnotetext{
${ }^{215}$ For a list of potential add-backs see Lawler (2007), p. 13.

${ }^{216}$ Cf. Tirole (2006), p. 86.

${ }^{217}$ Cf. Kahan/Tuckman (1993), p. 16.
} 
class of covenants that reduce the potential for accounting manipulation. Lenders and borrowers have to agree on an accounting method to calculate covenants for the term of the loan, like US-GAAP or IFRS. However, the chosen accounting method still leaves a substantial discretion on how to calculate EBITDA, for example. Therefore, each item going into the calculation of financial covenants, e.g. EBITDA, is defined in great detail in the debt agreement. Additionally, the quarterly calculation of financial covenants during the lifetime of the loan has to be certified by auditors and the chief financial officer of the firm. ${ }^{218}$ To support a standardization of accounting definitions the LMA issues standard definitions of certain accounting items like EBITDA. However, in leveraged buyouts the definitions of financial covenants are heavily negotiated. $^{219}$

\subsection{Covenants in Leveraged Buyouts}

The first question to address, when explaining the structure of covenants in LBOs is: why should it be any different compared to non-sponsored private debt? According to the banking relationship argument, LBO firms are large and repeated customers for banks, achieving lower cost of debt by reducing information asymmetries between the shareholder of the buyout company and the bank. Therefore, banks gain trust in the selection process of the private equity group over time and are keen to cross-sell other fee based services. Given the larger frequency and scale of transactions, PE groups are generally more important clients for banks than traditional corporate borrowers and, hence, should receive more favorable loan terms, i.e. more leverage, looser financial covenants $^{220}$, lower interest costs. ${ }^{221}$ Another argument that comes to the same conclusion is related to the role of reputation in debt markets. If the private equity group plans to sponsor future LBOs it has reduced incentives to engage in risk shifting from lenders to themselves. Consequently, lenders substitute reputation for lender control

\footnotetext{
${ }^{218}$ Cf. Chava/Roberts (2008), p. 2106.

${ }^{219}$ Cf. Lawler (2007), p. 10f.

${ }^{220}$ The prediction for the number of financial covenants is not clear, because more covenants do not necessarily mean stricter but more customized. Cf. Ivashina/Kovner (2010), p. 8.

${ }^{221}$ For the argument see Ivashina/Kovner (2010). For the return enhancing function of leverage see Achleitner et. al. (2010).
} 
and demand looser financial covenants. Lenders may be more favorable to customers who are likely to be more dependent on their lending and plan to finance transactions more frequently and larger in scale. Therefore, banks might be willing to give looser financial covenants to LBO firms as compared to corporate borrowers. ${ }^{222}$

However, there are two arguments that may attenuate the effects of banking relationship and reputation on financial covenant restrictiveness. Private equity sponsors may only be able to finance such transactions, i.e. utilize large amounts of debt, because of their lending relationships and reputation in combination with stricter financial covenants. Without these circumstances lenders would simply offer less leverage or not finance a given deal at all. ${ }^{223}$ Consequently, financial covenants in LBOs would not be comparable to non-sponsored loans as they are based on fundamentally different capital structures. A second argument may be related to the business model of private equity funds. Most private equity firms pool investments within funds and base the GP carry on aggregated returns from the pooled investments rather than calculating the carry on the performance of each individual deal.

Given a certain portfolio return, if an individual portfolio company defaults, the GP loses reputation and its investment in the company, whereas his carried interest remains identical. ${ }^{224}$ This structure minimizes the conflict of interest between GP and LP but as a byproduct it incentivizes the GP to engage in risk shifting detrimental to lenders of particular investments, especially at the end of the fund's lifetime ('end-period gaming'). By contrast, corporate borrowers mostly choose an infinite life for the firm and, looking at a similar concentration of ownership like in buyouts, shareholders are exposed to higher risk in case of a default on outstanding debt.

For instance, a family that owns a business has fewer incentives to engage in risky projects, ceteris paribus, than a private equity group: in case of default, the shareholder may lose the entire family wealth and the control over the family business, while the

\footnotetext{
${ }^{222}$ For the reputational argument see Demiroglu/James (2010b).

${ }^{223}$ Cf. Ivashina/Kovner (2010), p. 40.

${ }^{224}$ Cf. Axelson/Strömberg/Weisbach (2009), p. 1570.
} 
PE group writes off the investment and the expected fund return is reduced. This argument does not even consider the emotional ties to the business. Assuming that lenders observe these distinct incentives for risk shifting of borrowers, they would impose stricter covenants on loans sponsored by PE groups compared to non-sponsored loans with family ownership.

Renegotiation arguments could have an effect on the covenant setting if the costs of renegotiation would be structurally different in LBO loans as compared to nonsponsored loans. As both forms of ownership are concentrated and renegotiation mostly takes place with a small group of executives, either of the family business or the PE group, there is no reason why renegotiation costs should be systematically different.

After having explained why covenant structure in private equity backed leveraged buyouts may be different from non-sponsored loans, the remainder of the section describes the covenant structure in LBOs as reported in existing research. Due to restricted data availability, covenant structures in LBOs have been obscure to academia until recently, when Reuters LPC started collecting covenant data for LBOs in their Dealscan database.

On action-restricting covenants in LBOs, DEMIROGLU/JAMES (2010b) is the only academic work documenting empirical evidence. Confirming the notion of a strict covenant setting, DEMIROGLU/JAMES (2010b) report covenant index scores ${ }^{225}$ for 122 US LBOs in the period from 1997 to 2007. The covenant index ranges from 4.0 to $5.8^{226}$ which constitutes higher values than the average covenant intensity index for private debt of 3.9, reported by BRADLEY/ROBERTS (2004) for 8,553 loans. Besides the index DEMIROGLU/JAMES (2010b) report dividend restrictions separately. Out of 101 LBO loans, 98.8\% contain restrictions on dividend payments whereas 85.1\% of private debt agreements include dividend restrictions in BRADLEY/ROBERTS (2004).

\footnotetext{
${ }^{225}$ As defined by Bradley/Roberts (2004): the covenant intensity index equals the sum of six covenant indicators (collateral, dividend restriction, more than 2 financial covenants, asset sales sweep, equity issuance sweep, and debt issuance sweep). Cf. Bradley/Roberts (2004), p. 18.

${ }^{226}$ Demiroglu/James (2010b) do not give the detailed data on covenants and only show the aggregated averages per year.
} 
There are two studies covering financial covenants in US LBOs: DEMIROGLU/ JAMES (2010b) and IVASHINA/KOVNER (2010). Both studies use Dealscan, which includes types of financial covenants and the threshold. Therefore, their results on restrictiveness are limited to conclusions regarding the number of covenants and covenant thresholds. DEMIROGLU/JAMES (2010b) report that the average LBO loan contains 2.8 financial covenants, however, being strongly dependent on market conditions: in 2001 the average loan included 4.4 financial covenants while in 2007 each loan only included 0.8 financial covenants. In the same time period, the number of financial covenants in non-sponsored loans decreased from 3.4 to 2.5. Additionally, they found that 16 (59.3\%) out of 27 deals in 2007 were covenant-lite deals. ${ }^{227}$

IVASHINA/KOVNER (2010) analyze 1,590 US loans between 1993 and 2005 and find that the mean loan contains 2.9 financial covenants, whereas a control group of non-sponsored loans contains 3.2 financial covenants on average. IVASHINA/KOVNER (2010) identify the D/EBITDA covenant as the most prominent type of financial covenant in LBOs. Their data shows that $29.0 \%$ of sponsored loan agreements contain a D/EBITDA covenant. The most frequent combination of financial covenants - being present in $14.0 \%$ of sponsored loans - contains limits on D/EBITDA, EBITDA/I and FixedChargeCoverage. In terms of restrictiveness, they document that the mean D/EBITDA covenant threshold is 5.4 for sponsored and 4.4 for non-sponsored loans. However, IVASHINA/KOVNER (2010) admit that the comparison of their sponsored to non-sponsored loan terms is not ideal because the public companies are subject to considerably lower financial risk than buyout companies. Given the lack of comparable loans, they argue that the sponsoring by a private equity group not only alters the terms of a loan, but enables the issuance of the loan at all. ${ }^{228}$

To sum up, the empirical evidence suggests that action-restricting as well as financial covenants are more restrictive in sponsored loans than in non-sponsored loans. How-

\footnotetext{
${ }^{227}$ The study does not mention whether the covenant-lite deals are included in the calculation of the number of financial covenants. If one looks at the fraction of covenant-lite deals in 2007, 28 transactions are observed, with 16 being covenant-lite. However, looking at the number of financial covenants, there are 23 observed transactions.

${ }^{228}$ Cf. Ivashina/Kovner (2010), p. 39.
} 
ever, as already mentioned, the empirical evidence is very limited and the single existing study of IVASHINA/KOVNER (2010) acknowledges the absence of an adequate benchmark.

\subsection{Summary}

The chapters above explained and introduced types and usage of action-restricting and financial covenants in public, private and LBO debt. This chapter summarizes the findings by presenting an overview of covenants and providing a qualitative assessment of the restrictiveness of the individual covenant types in public, private and LBO debt agreements.

As derived above, Figure 13 allocates the types of covenants in two distinct categories: action-restricting and financial covenants. Action-restricting covenants have their theoretical foundation in the agency conflict between equity holders and debt holders. Equity holders accept covenants to reduce agency costs of debt that are caused by asset substitution, underinvestment or claim dilution. The theory of incomplete contracts explains the rationale for financial covenants, which transfer the signal for the shift in control rights to debt holders. In order to secure the effectiveness and the ability to enforce financial covenants, shareholders accept informational covenants and covenants limiting accounting manipulation. Besides the economic rationale to trigger the shift in control rights from borrowers to lenders, financial covenants also limit risk shifting behavior of borrowers. 


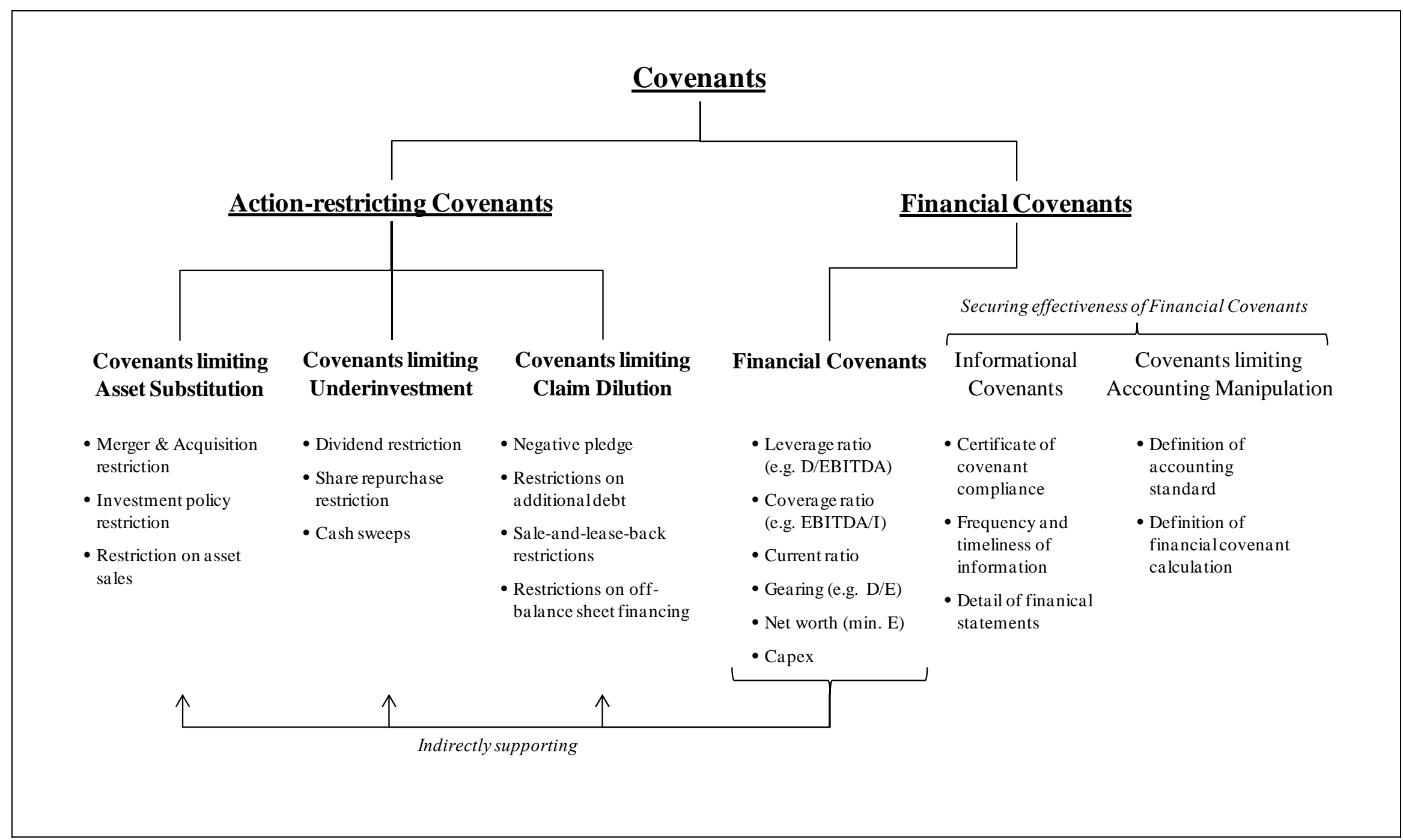

Figure 13: Systematization of covenants in credit agreements Source: Author 
Figure 14 provides an indicative picture of the usage of the different covenant types for public, private and LBO debt. The assessment is a qualitative comparison and based on existing empirical studies. Most studies are not concerned with the comparison across different debt types, but analyze the usage of covenants in one category of debt. Another caveat of such an illustration is that covenant structures deviate over time and are not standardized. On the side of action-restricting covenants, empirical literature does not differentiate between usage and restrictiveness, i.e. a covenant is either included or not. ${ }^{229}$ By contrast, the value of financial covenants can only be gauged when looking at the existence and the restrictiveness of financial covenants. For example, a D/EBITDA covenant in combination with an EBITDA/I covenant with both $30 \%$ headroom may be worth less than a D/EBITDA at 20\% headroom, because the latter may breach earlier.

Figure 14 shows that covenants are stricter in private debt compared to public debt. Action-restricting covenants are frequently used in public debt agreements but are even more frequent in private debt agreements. Public debt agreements are 'covenantlite', i.e. contain incurrence financial covenants, which do not fulfil the fundamental function of financial covenants to trigger a shift in control rights but support actionrestricting covenants. By contrast, corporate and LBO private debt contain maintenance financial covenants that have to be met on an ongoing basis throughout the loan. This notion of less restrictive covenant structures in public debt can be explained by three differences: lower information asymmetries between lenders and borrowers (i), higher renegotiation costs (ii), and lower incentives to monitor for lenders (iii).

\footnotetext{
${ }^{229}$ However, the individual clauses may be fundamentally different. For example, a cash sweep clause may force the borrower to repay $25 \%$ or $75 \%$ of the excess cash flow.
} 


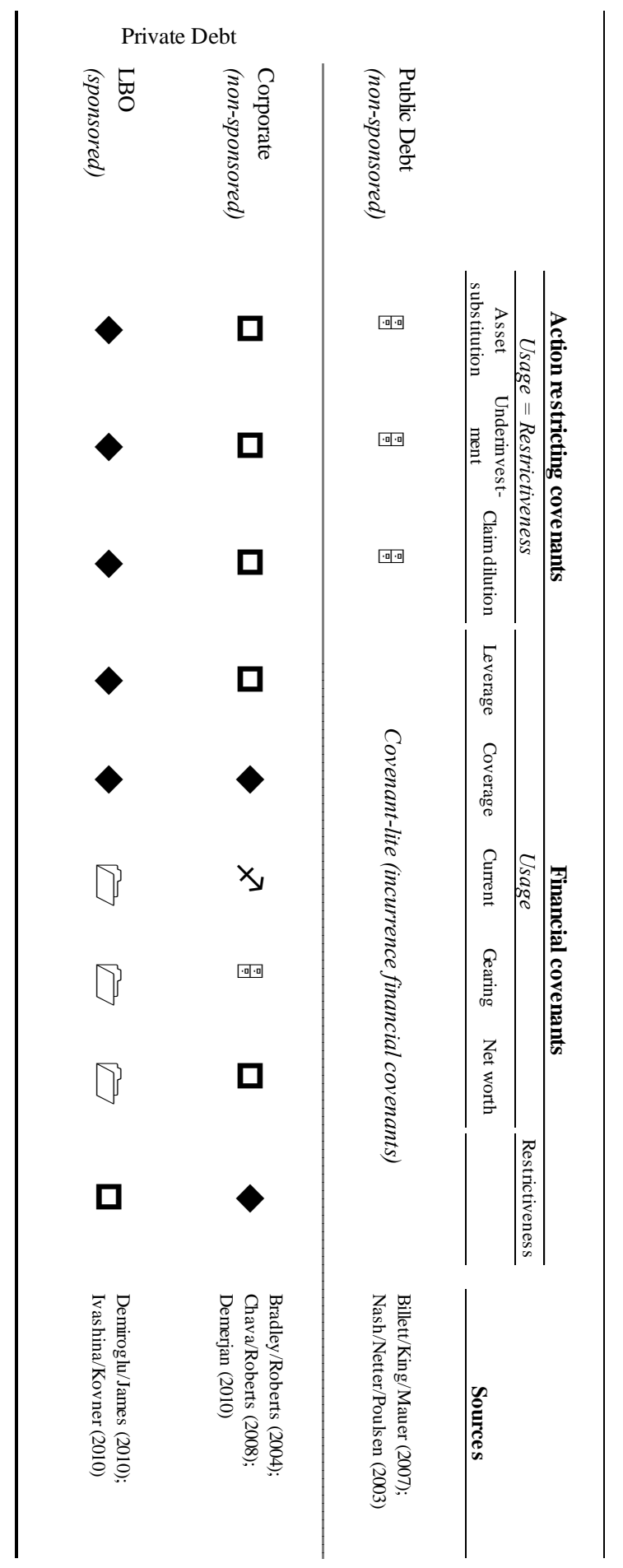

Figure 14: $\quad$ Covenants in public, private, corporate and LBO debt Source: Author 
The comparison between public and private debt covenants is well covered in the literature, whereas the academic ground that compares corporate (non-sponsored) to LBO (sponsored) loans is largely untapped. Therefore, the following impression may only be suggestive and the empirical part of this dissertation targets to strengthen the basis for this discussion.

Regarding the difference between corporate and LBO debt, action-restricting covenants seem to be more frequently used in sponsored as compared to non-sponsored debt. Financial covenants are frequently included in corporate and LBO debt. Leverage (e.g. D/EBITDA) and coverage (e.g. EBITDA/I) are very important in both, whereas net worth and gearing covenants are predominantly found in corporate debt agreements. As borrowers with positive earnings, high profitability and low earnings volatility are likely to contain coverage and leverage covenants and LBO firms are likely to belong to this category, this notion seems reasonable. While the usage of financial covenants in corporate and LBO debt is weakly documented, the restrictiveness is largely unsolved. The current literature hypothesizes that corporate loans contain more restrictive financial covenants than LBO loans, all else being equal. This suggestive analysis will be tested in the empirical section of this thesis. 


\section{Hypotheses}

\subsection{Introductory Remarks}

The present chapter develops hypotheses on the restrictiveness of financial covenants in LBO loans, which will be tested in the empirical part of the thesis. First, a brief description of the relevant literature on covenants and the main areas of research will be given. Second, the chapter constructs theoretical arguments - based on the agency theory of covenants, control rights theory but also adjacent theories - and links them to empirical findings to formulate hypotheses. Classifications of hypothesis are based on prior covenant literature.

\subsection{Literature Review}

This section gives an introduction to the relevant empirical literature ${ }^{230}$ on covenants and briefly explains their essential findings. Many seminal articles focus on actionrestricting covenants but their analysis of the conflicting interests between debt and equity holders may also be applied in the context of financial covenants. Therefore, this review covers literature on action-restricting as well as financial covenants.

Overall, covenant research seems to follow data availability. First, all relevant covenant research was undertaken with US samples, where data availability is better than in Europe. ${ }^{231}$ Second, earlier covenant research took place in two waves: during the late 1980s and early 1990s first empirical research analyzed small proprietary datasets as data availability was scarce. Recently, covenant research regained momentum as Dealscan started to offer comprehensive information on action-restricting as well as financial covenants.

Table 4 and Table 5 present the relevant literature on covenants. The research articles have been grouped into four different categories according to their primary area of re-

\footnotetext{
${ }^{230}$ For theoretical considerations see sections 3.2 and 3.3.

${ }^{231}$ One important reason is that European banks are not as willing to share loan terms with data providers as US banks.
} 
search along the lifecycle of covenants: covenant setting, covenant restrictiveness, covenant purpose and effectiveness and consequences of covenant violations.

The first category of covenant research concentrates on the covenant setting, meaning which types of covenants and why they are included in credit agreements. MALITZ (1986) tests implications from the costly contracting hypothesis on three types of action-restricting covenants. She finds firms with higher leverage to benefit more from the inclusion of covenants that restrict the financing and investment policy. Additionally, asymmetric information seems to play an important role for the value of covenants: covenants can mitigate costs arising from high information asymmetries between debt and equity holders.

NASH/NETTER/POULSEN (2003) also test implications derived from the costly contracting hypothesis developed by SMITH/WARNER (1979). Specifically, they examine the costs and benefits of covenants in public debt agreements. They find that firms with growth opportunities are keen to preserve their flexibility by not including dividend or debt issuance covenants. Another important finding is that financial risk determines the inclusion of action-restricting covenants.

BRADLEY/ROBERTS (2004) test predictions of the agency theory of covenants. They build a covenant index by counting the mere existence of action-restricting and financial covenants, i.e. secured debt, dividend restrictions, more than two restricted financial covenants, asset sweep, debt sweep and equity sweep. They find that a higher promised yield on private debt is negatively related to their covenant index. Additionally, they document that loans are likely to contain more covenants when borrowers are small, have high growth opportunities or have a high leverage. Finally, their research shows that loans issued during recessionary periods or when credit spreads are high contain more covenants. 


\begin{tabular}{|c|c|c|c|c|c|c|c|c|c|c|c|}
\hline \multirow[b]{2}{*}{ Author(s) } & \multirow[b]{2}{*}{ Year } & \multirow[b]{2}{*}{$\begin{array}{l}\text { Type of } \\
\text { debt }\end{array}$} & \multicolumn{4}{|c|}{ Category of Covenant Research } & \multirow{2}{*}{$\begin{array}{l}\text { Period } \\
\text { covered }\end{array}$} & \multirow[b]{2}{*}{ Region } & \multirow{2}{*}{$\begin{array}{l}\text { No. of } \\
\text { deals } \\
\text { (source) }\end{array}$} & \multirow[b]{2}{*}{ Paradigm / focus of study } & \multirow[b]{2}{*}{ Findings } \\
\hline & & & $\begin{array}{l}\text { Covenant } \\
\text { setting }\end{array}$ & $\begin{array}{l}\text { Restrictive } \\
\text {-ness }\end{array}$ & $\begin{array}{l}\text { Purpose / } \\
\text { effective- } \\
\text { ness }\end{array}$ & Violation & & & & & \\
\hline Malitz & (1986) & Public & $\checkmark$ & $\checkmark$ & & & $1960-1980$ & US & $\begin{array}{c}223 \\
\text { (Moody's) }\end{array}$ & - Testing costly contracting hypothesis & $\begin{array}{l}\text { - Borrowers with higer leverage receive more restrictive covenants } \\
\text { - Larger borrowers receive looser covenants } \\
\text { - Higher reputated borrowers receive looser covenants }\end{array}$ \\
\hline $\begin{array}{l}\text { Nash / Netter / } \\
\text { Poulsen }\end{array}$ & (2003) & Public & $\checkmark$ & & & & $1989-1996$ & US & $\begin{array}{l}310 \\
(\mathrm{SEC})\end{array}$ & $\begin{array}{l}\text { - Testing the relationship between } \\
\text { investment opportunities and covenants }\end{array}$ & $\begin{array}{l}\text { - Higher growth opportunities lead to looser covenants (dividend and } \\
\text { debt issuance restrictions) because borrowers value flexibility relatively } \\
\text { higher } \\
\text { - Other covenants are not related to growth opportunities }\end{array}$ \\
\hline Bradley / Roberts & (2004) & Private & $\checkmark$ & $\checkmark$ & & & $1993-2001$ & us & $\begin{array}{c}7,458 \\
\text { (Dealscan) }\end{array}$ & $\begin{array}{l}\text { Testing agency theory of covenants } \\
\text { Determinants and pricing of covenants }\end{array}$ & $\begin{array}{l}\text { - Macro environment influences covenant restrictiveness } \\
\text { - Yield on loans is a substitute for covenant restrictiveness }\end{array}$ \\
\hline $\begin{array}{l}\text { Billet / King / } \\
\text { Mauer }\end{array}$ & (2007) & Public & $\checkmark$ & & & & $1960-2003$ & us & $\begin{array}{l}15,504 \\
\text { (FISD) }\end{array}$ & $\begin{array}{l}\text { - Effect of growth opportunities on } \\
\text { leverage, maturity and covenants }\end{array}$ & $\begin{array}{l}\text { - Higher growth opportunities lead to more action-restricting } \\
\text { covenants, mitigating agency costs of debt } \\
\text { - Covenant protection is increasing with maturity and leverage }\end{array}$ \\
\hline $\begin{array}{l}\text { Chava / Kumar / } \\
\text { Warga }\end{array}$ & (2009) & Public & $\checkmark$ & & & & $1993-2007$ & US & $\begin{array}{l}4 ; 478 \\
\text { (FISD) }\end{array}$ & $\begin{array}{l}\text { - Effect of management agency conflicts } \\
\text { on covenants }\end{array}$ & $\begin{array}{l}\text { - Entrenched management increases the use of investment covenants } \\
\text { limiting 'empire building' } \\
\text { - The threat of managerial fraud leads to more covenants }\end{array}$ \\
\hline Demiroglu / James & (2010a) & LBO & $\checkmark$ & & & & $1997-2007$ & us & $\begin{array}{c}122 \\
\text { (Dealscan) }\end{array}$ & $\begin{array}{l}\text { - Effects of PE sponsor reputation on } \\
\text { financial covenants }\end{array}$ & $\begin{array}{l}\text { - Higher reputed private equity firms receive looser covennants } \\
\text { - Higher growth propects lead to more restrictive covenants } \\
\text { - Higher credit spread leads to more restrictive covenants } \\
\text { - Larger companies receive looser covenants }\end{array}$ \\
\hline Demerjian & (2010) & Private & $\checkmark$ & & & & $1987-2006$ & US & $\begin{array}{l}16,364 \\
\text { (Dealscan) }\end{array}$ & $\begin{array}{l}\text { - Selection of type of financial covenants } \\
\text { in private debt agreements }\end{array}$ & $\begin{array}{l}\text { - Borrowers with positive earnings, high profitability and low volatility } \\
\text { earnings are likely to include leverage and coverage covenants } \\
\text { - Borrowers with losses, low profitability and volatile earnings are likely } \\
\text { to include net worth covenants }\end{array}$ \\
\hline Ivashina / Kovner & (2010) & LBO & & $\checkmark$ & & & $1993-2005$ & US & $\begin{array}{c}1,590 \\
\text { (Dealscan) }\end{array}$ & $\begin{array}{l}\text { - Effect of relationship banking on } \\
\text { financial covenants }\end{array}$ & \begin{tabular}{|l}
$\cdot$ Higher banking relationship of PEG and bank leads to looser \\
covenants \\
$\cdot$ Higher historical fees paid from PEG to bank leads to looser covenants
\end{tabular} \\
\hline Demiroglu / James & (2010b) & Private & & $\checkmark$ & & & $1995-2001$ & US & $\begin{array}{l}11,600 \\
\text { (Dealscan) }\end{array}$ & $\begin{array}{l}\text { - Testing the signalling theory of } \\
\text { covenants } \\
\text {-Using covenants to predict future } \\
\text { nerformance }\end{array}$ & $\begin{array}{l}\text { - Borrowers that choose more restrictive covenants perform better than } \\
\text { lenders that choose looser covenants. }\end{array}$ \\
\hline
\end{tabular}

Table 4:

Literature overview I/II

Source:

Author 


\begin{tabular}{|c|c|c|c|c|c|c|c|c|c|c|c|}
\hline \multirow[b]{2}{*}{ Author(s) } & \multirow[b]{2}{*}{ Year } & \multirow{2}{*}{$\begin{array}{l}\text { Type of } \\
\text { debt }\end{array}$} & \multicolumn{4}{|c|}{ Category of Covenant Research } & \multirow{2}{*}{$\begin{array}{l}\text { Period } \\
\text { covered }\end{array}$} & \multirow[b]{2}{*}{ Region } & \multirow{2}{*}{$\begin{array}{l}\text { No. of } \\
\text { deals } \\
\text { (source) }\end{array}$} & \multirow[b]{2}{*}{ Paradigm / focus of study } & \multirow[b]{2}{*}{ Findings } \\
\hline & & & $\begin{array}{c}\text { Covenant } \\
\text { setting }\end{array}$ & $\begin{array}{l}\text { Restrictive } \\
\text {-ness }\end{array}$ & $\begin{array}{l}\text { Purpose / } \\
\text { effective- } \\
\text { ness }\end{array}$ & Violation & & & & & \\
\hline Dichev / Skinner & (2002) & Private & & & $\checkmark$ & & $1989-1999$ & us & $\begin{array}{c}2,810 \\
\text { (Dealscan) }\end{array}$ & - Debt covenant hypothesis & $\begin{array}{l}\text { - Financial covenants cause income increasing changes in accounting } \\
\text { policy }\end{array}$ \\
\hline Frankel / Litov & (2007) & Private & & & $\checkmark$ & & $1989-2004$ & us & $\begin{array}{c}6,161 \\
\text { (Dealscan) }\end{array}$ & $\begin{array}{l}\text { - Use of financial covenants and } \\
\text { accounting characteristics }\end{array}$ & $\begin{array}{l}\text { - Little association between financial covenants and reporting } \\
\text { characteristics } \\
\text { - Little association between covenant slack and reporting } \\
\text { characteristics }\end{array}$ \\
\hline Roberts / Sufi & (2009) & Private & & & $\checkmark$ & & $1996-2005$ & US & $\begin{array}{c}1000 \\
\text { (Dealscan) }\end{array}$ & $\begin{array}{l}\text { - Effect of financial covenants on } \\
\text { renegotiation of private credit agreements }\end{array}$ & $\begin{array}{l}\text { - Restrictiveness of financial covenants do not influence the probability } \\
\text { of renegotiation but the outcome of the renegotiation process } \\
\text { - } 95 \% \text { of credit agreements contain a finanicial covenant. } 82 \% \text { contain } \\
\text { cash flow covenant }\end{array}$ \\
\hline Zhang & (2009) & Private & & & $\checkmark$ & & $1988-2007$ & US & $\begin{array}{c}1,590 \\
\text { (Dealscan) }\end{array}$ & - Effectiveness of financial covenants & $\begin{array}{l}\text { - Better macroeconomic environment leads to looser covenants } \\
\text { - One standard deviation more restrictive covenants lead to X\% higher } \\
\text { reecovery rates }\end{array}$ \\
\hline Drucker / Puri & (2009) & Private & & & $\checkmark$ & & $1998-2005$ & US & $\begin{array}{c}2,674 \\
\text { (Dealscan) }\end{array}$ & $\begin{array}{l}\text { The role of debt covenants in loan sales } \\
\text { and the costs and benefits to corporate } \\
\text { borrowers }\end{array}$ & $\begin{array}{l}\text { - More restrictive covenants lead to higher salability of loans } \\
\text { - Covenants protect lenders from potential losses caused by } \\
\text { informationally advantaged borrowers }\end{array}$ \\
\hline Beneish / Press & (1993) & Private & & & & $\checkmark$ & $1983-1987$ & US & $\begin{array}{c}91 \\
(\mathrm{SEC})\end{array}$ & - Costs of covenant violation & $\begin{array}{l}\text {-Violations of financial covenants lead to increased financing costs, } \\
\text { asset divestments, lender control, waiver fees }\end{array}$ \\
\hline Chava / Roberts & (2008) & Private & & & & $\checkmark$ & $1994-2005$ & US & $\begin{array}{c}6,386 \\
\text { (Dealscan) }\end{array}$ & $\begin{array}{l}\text { - Violation of covenants and their impact } \\
\text { on investment restrictions }\end{array}$ & $\begin{array}{l}\text { - A violation of a financial covenant leads to restriction and reduction } \\
\text { of capital expenditures } \\
\text { - The reduction in investment is concentrated in situations in which } \\
\text { agency and information problems are more severe }\end{array}$ \\
\hline
\end{tabular}

Table 5:

Literature overview II/II

Source:

Author 
BILLETT/KING/MAUER (2007) analyze the effect of growth opportunities on the simultaneous decision of leverage, debt maturity and action-restricting covenants in public debt contracts. In contrast to NASH/NETTER/POULSEN (2003) they find that covenant protection is positively related to growth opportunities, financial risk and debt maturity. Applying a generalized method of moments approach they document that the tradeoff between leverage and growth opportunities is mitigated by covenant inclusion.

CHAVA/KUMAR/WARGA (2010) investigate the risk for bondholders from managerial moral hazard. They find that entrenched managers and increased risk of fraud significantly increase the use of financial covenants. However, the study also finds that entrenched managers alleviate the conflict between debt and equity holders as they sometimes resist shareholder opportunism.

DEMIROGLU/JAMES (2010b) analyze financial covenants in the context of LBOs. They measure the restrictiveness of covenants by simply counting the number of financial covenants included in the credit agreement. They find that higher reputation PE groups are likely to include less financial covenants. However, this effect is not robust when including time fixed effects. ${ }^{232}$

DEMERJIAN (2010) develops predictions on the role of financial covenants in private credit agreements and tests them empirically. The paper finds that income statement covenants are more likely used for borrowers with high leverage or high earnings performance. Also, the results show that the inclusion of balance sheet covenants is negatively related to leverage and earnings performance.

The second category of research looks at the determinants of financial covenant restrictiveness. IVASHINA/KOVNER (2010) investigate the effect of banking relationships between private equity groups and banks on the restrictiveness of financial covenants. They measure financial covenant restrictiveness in terms of the D/EBITDA covenant threshold. When controlling for all relevant capital structure variables, they

\footnotetext{
${ }^{232}$ In earlier working paper versions they also analyzed the covenant threshold for 56 transactions. In later versions this analysis was dropped.
} 
document that repeated interaction and cross-selling potential are positively related to the D/EBITDA covenant threshold. This means higher banking relationship leads to lower restrictiveness of financial covenants.

DEMIROGLU/JAMES (2010a) explore the information content of the restrictiveness of financial covenants in private credit agreements, i.e. they effectively test the signaling theory of covenants. They show that lenders use the restrictiveness of financial covenants as a channel to convey private information. Therefore, more restrictive financial covenants serve as a signal to lenders that the borrower is confident to perform. In line with this argument, the paper shows that tighter covenants are positively related to performance improvements ex post.

The third group of articles looks at the purpose and effectiveness of covenants. DICHEV/SKINNER (2002) find evidence for the debt covenant hypothesis, i.e. that borrowers have incentives to engage in earnings manipulation to avoid covenant breaches. They also document that technical violations of covenants take place in about $30 \%$ of private credit agreements.

FRANKEL/LITOV (2007) analyze the relationship between financial covenants and financial reporting characteristics. They argue that financial covenants should be more effective and therefore more often included when financial reporting of the borrower is of better quality. However, their empirical research yields only limited evidence for this hypothesis.

ROBERTS/SUFI (2009) investigate the effect of financial covenant restrictiveness on the outcome of renegotiations in private credit agreements. They show that the restrictiveness of financial covenants does not reduce the likelihood of costly renegotiation but they influence the outcome of renegotiations, i.e. it allocates bargaining power during the renegotiation process. In other words, more restrictive covenants increase the bargaining power in renegotiations.

ZHANG (2009) is the only study that looks at the influence of covenant restrictiveness on recovery rates in firm-level defaults. Covenant restrictiveness is measured as a sim- 
ple count variable. An increase of covenant restrictiveness by one standard deviation leads to an increase of the default recovery rate of at least $6.0 \%$ of the loan principal.

DRUCKER/PURI (2009) examine the secondary market for loan sales to see whether the inclusion of covenants can reduce agency problems between lenders and borrowers. They find that covenants significantly help loan sales in the secondary market because covenants reduce potential costs arising for the buyer from 'informationallyadvantaged' loan sellers and borrowers.

The fourth category of covenant research analyzes the consequences of covenant violations. CHAVA/ROBERTS (2008) show that, by using a regression discontinuity design, capital expenditures decline significantly after a financial covenant violation. The reduction in investment is more severe in situations with strong agency problems. Consequently, they identified a channel, i.e. covenants, how financing frictions interfere with the firm's investment policy.

BENEISH/PRESS (1993) are the first to study the costs of violating financial covenants. They not only examine the direct costs of refinancing and restructuring but also costs that arise due to changes of financing and investment decisions. Estimates of the costs related to a covenant breach range from $1.2 \%$ to $2.0 \%$ of market value of equity.

Overall, there is lots of research on leveraged buyouts and also lots on covenants, however, covenants in leveraged buyouts are still neglected. Therefore, the following sections try to shed light on this research gap by developing hypotheses on the determinants of restrictiveness of financial covenants in LBOs and then by testing them empirically.

\subsection{Hypotheses Development}

The presented covenant literature suggests five distinct categories of factors that determine financial covenant restrictiveness: target related, transaction related, sponsor related, lead arranger related and macroeconomic related categories. The presented research model in Figure 15 incorporates these categories. The subsequent sections explain the potential role of the categories' specific determinants on financial covenant 
restrictiveness and formulate explicit hypotheses. The arguments apply agency and control rights theory, refer to adjacent theoretical constructs and incorporate findings from existing empirical research.

Target related (Section 5.3.1)

- Firm Size

- Growth

- Profitability

- Firm Risk

- Tangibility

Transaction related (Section 5.3.2)

- Leverage

- Interest Costs

- Maturity

- Share of Bank Debt

- Creditor Rights Dilution

Sponsor related (Section 5.3.3)

- Sponsor Reputation

- Banking Relationship

Lead arranger related (Section 5.3.4)

- Organization

- Final Hold

Macroeconomic related (Section 5.3.5)

Figure 15: Determinant categories of financial covenant restrictiveness Source: Author

\subsubsection{Target related}

\subsubsection{Firm Size}

There are several theoretical arguments that may explain the relation between the size of the borrower and the restrictiveness of financial covenants. First, larger companies may simply be less likely to go bankrupt because they are more diversified, have less volatile earnings and are better able to sell their assets in case of distress. The reduced probability of default in combination with the increased recovery rates of larger companies, lenders may be willing to accept looser covenants. Supporting these arguments 
numerous scholars ${ }^{233}$ document that larger firms - public or private - receive looser financial covenants in their loan agreements.

Second, the size of the firm is generally related to historical success and a long track record of repayment which generates a reputation in debt markets. Conflict of interest problems become less severe with increasing reputation. ${ }^{234}$ This implies that new borrowers with no or short track records face more severe conflicts of interest and most likely utilize costly means to mitigate those problems, such as restrictive covenants in their credit agreements to avoid higher interest rates. Over time the reputation itself becomes a valuable asset and a single default causes a large decline in its value. ${ }^{235}$ Therefore, the borrower has an incentive to avoid default and, consequently, conflicts of interest between borrowers and lenders are attenuated. Hence, larger companies may receive less restrictive financial covenants. However, the reputational argument may be relatively lower for buyout firms. As the private equity sponsor has larger interaction with the capital market, in both frequency and scale, lenders will more likely gauge the transaction based on the private equity group reputation. ${ }^{236}$

Third, the banking relationship argument states that borrowers with closer relationships to their banks receive less restrictive covenants. Repeated interactions between banks and borrowers reduce asymmetric information costs. ${ }^{237}$ Although the primary banking relationship is between the PE group and the lead bank, the borrower may still benefit from pre-buyout banking relationships. If the bank has built a historic relationship with the buyout company and has aggregated private information of the buyout company it will try to become the lead arranging bank or at least participate in the syndicated loan. As repeated interactions lead to reduced costs of monitoring and screening, borrowers with stronger relationships to lenders may receive looser financial covenants. Therefore, larger buyout companies are likely to have stronger and es-

\footnotetext{
${ }^{233}$ Cf. Billett/King/Mauer (2007), Bradley/Roberts (2004), Demiroglu/James (2010b), Malitz (1986).

${ }^{234}$ Cf. Diamond (1989), p. 828.

${ }^{235}$ Cf. Diamond (1989), p. 829. See also Smith/Warner (1979). Other measures may include additional monitoring by the lender. See Diamond (1984), Diamond (1991).

${ }^{236}$ Cf. Ivashina/Kovner (2010), p. 2.

${ }^{237}$ For a survey on banking relationship literature see Boot (2000).
} 
tablished banking relationships and may therefore receive looser covenants. These arguments result in the following hypothesis:

\section{H1: Larger buyout firms receive looser financial covenants}

\subsubsection{Growth}

MYERS (1977) identifies a potential underinvestment problem for levered, highgrowth firms. A large portion of the enterprise value is accounted for by assets not yet in place in the form of future investment opportunities, which are dependent on the discretionary decisions of the party in control. These growth opportunities can be regarded as 'real options' because equity holders may decide not to exercise their option. However, if most of the gains from investing are to be paid to lenders so that borrowers do not earn their required return, borrowers have incentives to reject a positive NPV investment. This situation is more likely to occur when more costly debt service payments are to be made. The theoretical construct would imply that lenders impose more restrictive covenants on high-growth LBOs. Many empirical studies, like the prominent article of BILLETT/KING/MAUER (2007), found confirming evidence for this idea, however, only for action-restricting covenants.

Regarding the relationship between growth prospects and financial covenant restrictiveness existing literature proposes two different views. The first view is based on the borrower's private information of future performance and his signaling behavior to attenuate adverse selection problems. LANDIER/THESMAR (2009) developed a theoretical model on the interaction of entrepreneurial confidence and financial contracting. They find that optimistic entrepreneurs self-select short-term debt as they are confident that the state of the firm at maturity will be 'good', i.e. expect superior growth rates for a given project. This construct may be transferred to financial covenants, which are the device to detect the state of the firm, projecting that optimistic managers are willing to accept strict financial covenants, as they are convinced that the state of the firm will remain 'good' and financial covenants are not violated. ${ }^{238}$ Consequently, the choice of covenant restrictiveness may serve as a signaling device from borrowers

${ }^{238}$ Cf. Landier/Thesmar (2009). 
to lenders to reduce adverse selection problems. ${ }^{239}$ This theoretical construct is often referred to as the 'signaling theory of covenants'. DEMIROGLU/JAMES (2010a) empirically test the implications for financial covenants and find that financial covenants are more restrictive for high growth firms. This argument results in the following hypothesis:

H2a: Buyout firms with high growth opportunities receive tighter financial covenants

The second view is based on the economic considerations on the value of flexibility for the equity holder. Restrictive financial covenants may constrain the PE group and the buyout management from taking wealth-increasing actions for the LBO firm, focusing on not violating the financial covenants. As the embedded growth options for the equity holders are more valuable for high-growth firms, these firms will value flexibility more than comparable low-growth firms. Therefore, high-growth firms may be less likely to accept restrictive financial covenants. ${ }^{240}$ The model of FRIEDMAN (2007) suggests that optimistic entrepreneurs strongly believe in their own capabilities, i.e. are overconfident, and therefore expect higher cash flows for given projects they are involved in, while simultaneously perceiving lower associated risks. ${ }^{241}$ In addition, overconfident managers are convinced that they can successfully manage their firm. Hence, their control aversion is even greater and they might insist even more to prevent a dilution of control over their project. ${ }^{242}$ There are no empirical studies that confirm this relationship. However, based on theoretical arguments the following hypothesis will be tested:

H2b: Buyout firms with higher growth options receive looser financial covenants

\footnotetext{
${ }^{239}$ Cf. Dessein (2005) and Gârleanu/Zwiebel (2009).

${ }^{240}$ Cf. Nash/Netter/Poulsen (2003).

${ }^{241}$ Cf. Friedman (2007).

${ }^{242}$ Cf. Fairchild (2007), Friedman (2007).
} 


\subsubsection{Profitability}

Historical performance is an informative indicator of future performance and therefore the quality of the borrower and the loan. ${ }^{243}$ Profitability therefore increases the likelihood of future cash flows being available to repay outstanding debt, which reduces the likelihood of bankruptcy. CORNELL/SHAPIRO (1987) argue that profitability is a signal for reputation and that successful firms are able to increase their financial risk over time. ${ }^{244}$ Lenders therefore might assume that a more profitable borrower has a higher likelihood of 'good' behavior during the life of the loan and faces lower agency costs of debt. ${ }^{245}$ Empirically, BEGLEY/CHAMBERLAIN (2006) show that companies with higher profitability receive a lower number of financial covenants. The theoretical argument and the empirical findings suggest the following hypothesis:

H3: Buyout firms with higher profitability receive looser financial covenants

\subsubsection{Firm Risk}

The firm's specific risk, i.e. the cash flow volatility, is regarded as one of the primary determinants of capital structure. ${ }^{246}$ In an agency theoretic context more volatile cash flows lead to increased incentives and opportunities for asset substitution. MATHER (1999) states that 'the greater the volatility of the borrowing firms' returns, the greater the incentive and opportunities for borrowers to engage in post-contractual opportunism. ${ }^{247}$ Thus, borrowers with volatile cash flows are faced with high agency costs of debt and would benefit more from an increased covenant protection. ${ }^{248}$

Among others, BRADLEY/ROBERTS (2004), BILLETT/KING/MAUER (2007) as well as DEMIROGLU/JAMES (2010b) find significant evidence for a higher number

\footnotetext{
${ }^{243}$ Cf. Dechow (1994), Dechow/Kothari/Watts (1998).

${ }^{244}$ Cf. Cornell/Shapiro (1987), p. 12.

${ }^{245}$ Cf. Begley/Chamberlain (2006), p. 22.

${ }^{246}$ Cf. Kale/Noe/Ramirez (1991), p. 1693.

${ }^{247}$ Cf. Mather (1999), p. 31.

${ }^{248}$ Cf. Bradley/Roberts (2004), p. 18.
} 
of covenants in loan agreements of borrowers with higher risk. ${ }^{249}$ Relating this argument to financial covenants, lenders may demand tighter covenants to prevent owners from risk shifting as early as possible. Because business risk is the cash flow volatility that is independent from financing decisions, the following hypothesis can be formulated:

H4a: Buyout firms with higher business risk receive tighter financial covenants

However, empirical findings on the relation of financial covenants and cash flow volatility are not homogeneous. Although DEMIROGLU/JAMES (2010b) indicatively document that companies with higher cash flow volatility receive more financial covenants, however, they also find that higher risk leads to less restrictive financial covenants. ${ }^{250}$ Other studies that examine covenant slack or absolute thresholds as dependent variables find similar results. ${ }^{251}$ This group of authors argues that lenders grant more flexible covenants to reduce the frequency of costly renegotiations stemming from volatility that is unrelated to changes in the borrowers' idiosyncratic risk characteristics. ${ }^{252}$ For example, a covenant violation which was caused by simple seasonal volatility may only cause unnecessary costs. This view results in the following hypothesis:

H4b: Buyout firms with higher business risk receive looser financial covenants

\subsubsection{Tangibility}

The tangibility of a firm's asset mix, often measured as the ratio of fixed-to-total assets, is another important determinant of financial structure, being positively related to leverage. ${ }^{253}$ The rationale is that tangible assets better preserve their value during default and, consequently, increase recovery rates. Another common explanation is that

\footnotetext{
${ }^{249}$ Cf. Billett/King/Mauer (2007), p. 719, Bradley/Roberts (2004), p. 37, Demiroglu/James (2010b), p. 323.

${ }^{250}$ This finding was part of the earlier working paper version of Demiroglu/James (2010b), which can be downloaded at http://www.bi.no/OsloFiles/ccgr/Demiroglu_James.pdf.

${ }^{251}$ Cf. Dichev/Skinner (2002), pp. 1107.

${ }^{252}$ Cf. Dichev/Skinner (2002), pp. 1106.

${ }^{253}$ Cf. Rajan/Zingales (1995).
} 
agency problems between debt and equity holders are less severe for firms with higher asset tangibility. ${ }^{254}$ For instance, it is more difficult for borrowers operating power plants or oil refineries to change the riskiness of their business to engage in asset substitution as compared to, for example, an investment bank. In line with this idea, BEGLEY/CHAMBERLAIN (2006) for public debt and BRADLEY/ROBERTS (2004) for private debt show that lower tangibility of assets is related to more actionrestricting covenants. Concerning the restrictiveness of financial covenants, lower asset tangibility increases the potential for risk shifting and, therefore, needs tight monitoring leading to following hypothesis:

H5: Buyout firms with lower asset tangibility receive tighter financial covenants

\subsubsection{Transaction related}

\subsubsection{Leverage}

Leverage is an important driver of value creation in LBOs, contributing about one third of returns to private equity investors. ${ }^{255}$ Consequently, the amount of debt used to acquire a target company is one of the most intensely negotiated items between PE groups and lead arrangers. Agency theory predicts that more debt increases the incentives for asset substitution and underinvestment. To protect the lender from risk shifting actions, loan agreements are expected to include more action-restricting covenants as well as tighter financial covenants.

While there is no academic study relating leverage to the restrictiveness of financial covenants, BILLETT/KING/MAUER (2007) show that higher leverage is related to more action-restricting covenants. A complementary argument is that leverage and financial covenant restrictiveness are determined simultaneously during negotiations and that they are substitutes. PE groups may face a trade-off between higher leverage and tighter financial covenants. However, as higher leverage increases the equity return substantially the maximization of the debt package seems to be the primary goal

\footnotetext{
${ }^{254}$ Cf. Parsons/Titman (2008), p. 19.

${ }^{255}$ Cf. Achleitner, et al. (2010).
} 
of the private equity investor during the first phase of negotiations. ${ }^{256}$ The structure and restrictiveness of financial covenants are negotiated thereafter. Based on the high leverage level, lenders will anticipate the high potential for opportunistic behavior, all else being equal and demand an earlier shift of control rights, i.e. more restrictive financial covenants:

H6: Buyout firms with higher leverage receive tighter financial covenants

\subsubsection{Interest Costs}

According to the agency theory of covenants, the decision to write a covenant into the loan agreement is determined simultaneously with the pricing of the loan. The costly contracting hypothesis states that the borrower has to weigh the costs from including a covenant against the decrease in interest costs. In other words, theory predicts that there exists a trade-off between covenant restrictiveness and the spread demanded by lenders. BRADLEY/ROBERTS (2004) find significant evidence for this relationship as they report a significant negative relation between the likelihood of a covenant inclusion and the resulting loan spread. ${ }^{257}$ It may be difficult to transfer this finding to financial covenant restrictiveness in LBOs, since interest rates on loans seem to experience low variation and are seemingly standardized. ${ }^{258}$ Additionally, the restrictiveness of financial covenants is not determined simultaneously with the pricing of the loan during the origination of a leveraged loan. The pricing of the loan is merely an input for the calculation of financial covenants. However, based on theoretical arguments and the empirical findings for private debt the thesis will test the following hypothesis:

H7: Buyout firms paying less interest cost receive tighter financial covenants

\footnotetext{
${ }^{256}$ Cf. Lawler (2007), p. 10.

${ }^{257}$ Cf. Bradley/Roberts (2004), p. 43f.

${ }^{258}$ Cf. Kaplan/Stein (1993), p. 330.
} 


\subsubsection{Maturity}

MYERS (1977) theorizes that shortening the maturity of debt reduces the potential for opportunistic behavior for borrowers. If the outstanding debt matures before an investment option is to be exercised incentives for suboptimal investment behavior are reduced. A shorter term debt structure creates a setting of continuous and gradual renegotiation. ${ }^{259}$ In addition, JENSEN (1986) argues that short maturity increases the required debt service incentivizing managers to increase efforts to generate cash and avoid wasting resources. ${ }^{260}$ In case long-term debt is issued, the ATC predicts that the use of covenants may compensate the increased potential for agency conflicts as there is the possibility to shorten the effective maturity of the loan contingent on the receipt of early warning signals. Consistent with theory, existing empirical evidence has mainly found a positive relation between the presence of covenants and the maturity of debt. Among others, BILLETT/KING/MAUER (2007) document that for public debt issues, a higher share of short term debt is associated with a lower number of actionrestricting covenants. ${ }^{261}$ DEMIROGLU/JAMES (2010a) as well as BRADLEY/ ROBERTS (2004) find similar results for private debt samples. ${ }^{262}$ However, there is no empirical evidence that suggests that this relation also holds true for the restrictiveness of financial covenants. DEMIROGLU/JAMES (2010a) do not find a significant relation between covenant slack and maturity. ${ }^{263}$ For LBOs, IVASHINA/KOVNER (2010) document - against the notion laid out above - that longer weighted maturities imply looser financial covenants. However, their analysis does not include D/EBITDA as an independent variable, which directly affects maturities. Another caveat to the relationship between maturities and financial covenant restrictiveness in LBOs is that maturities, like spreads, are standardized for equivalent tranches and weighted maturities are mainly driven by the chosen capital structure. ${ }^{264}$ Nevertheless, based on the theoretical

\footnotetext{
${ }^{259}$ Cf. Myers (1977), p. 154.

${ }^{260}$ Cf. Tirole (2006), p. 82.

${ }^{261}$ Cf. Billett/King/Mauer (2007), p. 719.

${ }^{262}$ Cf. Bradley/Roberts (2004), p. 43, Demiroglu/James (2010a), p. 42.

${ }^{263}$ Cf. Demiroglu/James (2010a), p. $40 f$.

${ }^{264}$ These findings were indicated by interviews and confirmed in the empirical data.
} 
arguments and existing empirical evidence, the thesis will test the following hypothesis:

H8: Debt packages with longer maturities contain tighter financial covenants

\subsubsection{Share of Bank Debt}

Banks are thought to have a comparative advantage in monitoring as formalized by DIAMOND (1984). ${ }^{265}$ The reason is that banks have a cost advantage in collecting loan related information against the alternatives of duplication effort if each lender monitors directly, or a fee-rider problem, in which case no lender monitors. ${ }^{266}$ In LBOs, the share of bank debt in total LBO financing seems to be positively related to the performance of buyouts. ${ }^{267}$ Bank financing plays such an important role in highly leveraged transactions (HLTs) that the majority of LBO financing is provided through bank loans. ${ }^{268}$ Also, as described in section 3.3.3, RAJAN/WINTON (1995) state that long-term debt is chosen when monitoring is socially optimal and the bank has incentives to monitor via financial covenants. Consequently, a higher share of bank debt should induce higher monitoring efforts and tighter financial covenants.

\section{H9a: A higher share of bank debt leads to tighter financial covenants}

In contrast to the argument above, PARK (2000) argues that the usage of subordinated debt, i.e. non-bank debt, in LBOs increases the incentive for the senior debt holders, i.e. banks, to monitor the borrower. The rationale behind this argument is that the higher the share of bank debt of total debt, the more 'equity-like' is the claim of the debt holder. ${ }^{269}$ RAUH/SUFI (2009) find empirical evidence for this argument. Therefore, one could formulate the contrary hypothesis to H9a:

\footnotetext{
${ }^{265}$ Diamond (1984) cites a passage of Schumpeter 1939, which motivated him to investigate the role of banks: '... the banker must not only know what the transaction is which he is asked to finance and how it is likely to turn out but he must know the customer, his business and even private habits, and get, by frequently talking things over with him, a clear picture of the situation.'

${ }^{266}$ Cf. Diamond (1984), 393.

${ }^{267}$ Cf. Kaplan/Stein (1993), p. 330.

${ }^{268}$ See for example Kaplan/Stein (1993) or Demiroglu/James (2010b).

${ }^{269}$ Cf. Park (2000). See also Rauh/Sufi (2009) for a recent empirical study.
} 
H9b: A higher share of bank debt leads to looser financial covenants

\subsubsection{Creditor Rights Dilution}

Besides the restrictiveness of financial covenants, the effectiveness of the financial covenants is essential to execute control in case of a violation of a financial covenant. However, the functioning of covenants may be deterred if loan agreements contain clauses, which alleviate the primary purpose to transfer control rights from borrowers to lenders in the case of a covenant breach. Assuming a declining marginal utility function for loosening covenants borrowers may want to swap a unit of covenant looseness with a clause attenuating the consequences of a covenant violation. Given the agency problem between informed and uninformed lenders ${ }^{270}$, lead arrangers may have incentives to accept these 'private' and hardly observable information while maintaining the public signal of credit quality in terms of financial covenant restrictiveness. Consequently, creditor rights dilution may increase financial covenant restrictiveness, i.e. financial covenants would be looser without creditor rights dilution. Therefore, the following hypothesis will be tested:

H10: A higher level of creditor rights dilution leads to tighter financial covenants

\subsubsection{Sponsor related}

\subsubsection{Sponsor Reputation}

DIAMOND (1989) theoretically analyzes the effect of reputation in debt markets. He argues that borrowers with a short track record have greater incentives to engage in risk shifting activities than reputable borrowers. For borrowers with successful track records the benefits from a high debt market reputation are considerable and, consequently, they act in a way to preserve it.

As hypothesized in section 5.3.1.1, the perceived quality of the borrower, i.e. buyout firm, might reduce monitoring efforts of the lenders. As PE groups interact more fre-

${ }^{270}$ Cf. Gorton/Pennacchi (1995), Holmström/Tirole (1997). 
quently and in larger scale with capital markets than traditional corporate borrowers, the reputation of the $\mathrm{PE}$ group is likely to dominate the reputational effect of the buyout company. Lenders assign superior due diligence, screening and operational capabilities to PE groups with a long and successful track record. Moreover, private equity sponsors build reputation over time, based on their historical investment performance and are able to conserve their outperformance. ${ }^{271}$ However, LER- $^{2}$ NER/LEAMON/HARDYMON (2010) state that this relationship holds true until a certain tipping point, where the business is not scalable any more. ${ }^{272}$ This superior performance of higher reputed sponsors seems to stem from active ownership and governance mechanisms. ${ }^{273}$ Consistent with the view of lenders and sponsors, reputation signals 'good' future behavior of the sponsor and, therefore, leads to reduced restrictiveness of financial covenants.

A similar relationship can be observed for the underwriter reputation in initial public offerings (IPOs). ${ }^{274}$ This argument, which is mostly applied to the conservation of the 'good' status of the firm during the loan period, could also be transferred to the behavior of PE groups when their portfolio company is in technical or payment default. Reputable PE groups have more financial resources to inject additional equity and thereby reduce loss of lenders and are also more likely to inject equity to conserve the value of their reputational benefits.

Another explanation for better loan terms may be market timing. Reputable PE groups typically have specialized teams focusing on the market terms in the syndicated loan market. Loan terms vary frequently and a strict observation of the developments may enable PE groups to exploit 'windows of opportunities'. Additionally, reputable PE groups may attract better talent to realize and exploit opportunities in the syndicated loan market.

\footnotetext{
${ }^{271}$ Cf. Kaplan/Schoar (2005).

${ }^{272}$ For private equity groups this point is estimated at around $\$ 1 \mathrm{bn}$ in fund size, whereas the return for venture capital funds decreases after a fundsize of circa \$150million. Lerner/Leamon/Hardymon (2010), p. 11.

${ }^{273}$ Cf. Acharya/Hahn/Kehoe (2010).

${ }^{274}$ See e.g. Carter/Dark/Singh (1998).
} 
DEMIROGLU/JAMES (2010b) empirically explored the effect of PE group reputation on the capital structure in US public-to-private (P2P) LBOs. The study finds that buyouts sponsored by high reputation PE groups pay lower interest margins, receive more leverage, utilize less senior debt and enjoy less financial covenants. The relationship between reputation and financial covenants is not robust against the inclusion of time fixed effects. A related study by AXELSON et al. (2010) finds that higher reputation leads to more leverage when not controlling for the size of the buyout firm. The theoretical arguments in combination with the empirical evidence allow the following hypotheses:

H11: Loans sponsored by high reputation PE groups receive looser financial covenants

\subsubsection{Banking Relationship}

Earlier literature, like e.g. BENSTON/SMITH (1976), grounded the existence of financial intermediates on transaction cost theory, while BHATTACHARYA/ THAKOR (1993) conclude that asymmetric and proprietary information is the fundamental rationale for the existence of intermediaries. Therefore, recent banking literature primarily focused on the function of banks as relationship lenders. Over time, with repeated interactions, banks develop relationships with borrowers, facilitating monitoring and screening which reduces informational asymmetry. ${ }^{275}$ Relationship banking literature primarily focused on commercial bank lending to small firms. ${ }^{276}$ However, BOOT (2000) notes that '... relationships also play a critical role in investment banking as well as [...] in private equity and debt markets. ${ }^{277}$ To test whether relationship banking is present, BERGER (1999) formulates three conditions that have to be met:

1. The intermediary gathers information beyond readily available public information;

\footnotetext{
${ }^{275}$ Cf. Boot (2000), p. 7.

${ }^{276}$ See for example Bharath, et al. (2007).

${ }^{277}$ Cf. Boot (2000), p. 8.
} 
2. Information gathering takes place over time through multiple interactions with the borrower, often through the provision of multiple financial services;

3. The information remains confidential (proprietary) and is used by the bank to make additional lending decisions to the same borrower. ${ }^{278}$

In LBOs, private equity groups, although not being the direct borrower, negotiate with the lead arranging bank on the lending terms. LBOs mostly involve high information asymmetries given that buyout companies are primarily private firms before the takeover and public information is limited. Additionally, transaction structures can be highly complex and opaque. ${ }^{279}$

Banks collect private information about PE groups and their investment behaviour to reduce information asymmetries (condition 1). This information includes the PE group's investment performance, due diligence process, incentive structures and operational capabilities. ${ }^{280}$ Moreover, the bank will look at historical renegotiations and the behaviour of the PE group towards lenders. These observations enable the lead arranger to assess the danger of the PE group engaging in risk shifting ex ante. Since the lead arranger generally monitors the loan, he interacts frequently with the PE group during the duration of the loan. Given the higher frequency and larger scale in capital market interactions, PE groups are also important customers for multiple financial services of the bank. These services may include M\&A advisory or IPO/bond underwriting (condition 2). Information on LBOs remains private and lead banks gather information on all prior interactions and fees with the PE group when deciding on a loan (condition 3) ${ }^{281}$ Consequently, the repeated interaction between the PE group and the bank can be called relationship banking.

Reduced information asymmetry due to the close banking relationship has important implications for the loan contracts written between banks and PE groups. The contrac-

\footnotetext{
${ }^{278}$ Cited in Ivashina/Kovner (2010) and Boot (2000).

${ }^{279}$ Cf. Ivashina/Kovner (2010), p. 6.

${ }^{280}$ Cf. Ivashina/Kovner (2010), p. 6.

${ }^{281}$ Cf. Ivashina/Kovner (2010), p. 9.
} 
tual benefit is expressed in easier renegotiations and more flexible contracting. ${ }^{282}$ The reduced information asymmetry helps to detect risk shifting behavior of the PE group and potential conflicts of interest. GÂRLEANU/ZWIEBEL (2009) assume that renegotiations are costly and that contracts are written to minimize these costs, predicting that reduced information asymmetry leads to looser financial covenants. ${ }^{283}$ Consequently, better informed banks are less likely to expect frequent renegotiations to reassess the loan, granting more private benefit extraction to the related PE group, hence looser financial covenants. IVASHINA/KOVNER (2010) confirm this notion showing that a closer banking relationship is related to a higher D/EBITDA covenant threshold. Therefore, the following hypothesis shall be tested:

\section{H12a: A stronger banking relationship leads to looser financial covenants}

Besides these relationship arguments that should loosen financial covenants, it is important to note that banking relationship and reputational assets are closely related, especially for large PE groups. The reputation of PE groups is closely correlated with size, number of deals and lifetime (which are also all correlated). ${ }^{284}$ The more assets a PE group has under management, the lower are information asymmetries and the reputational asset outweighs the relationship argument. For instance, a bank that has no prior relationship with Kohlberg Kravis \& Roberts (KKR) would be keen to offer generous loan terms, including loose covenants, since the reputational effect of KKR is considerable and the opportunity for future business is tempting. Also, banking relationships may experience negative marginal utility for borrowers, when the related bank acquires an information monopoly leading to a hold-up problem. This constellation could lead to increased costs of debt ex post. Large PE groups may therefore use multiple banks and reduce the value of information to any individual bank. ${ }^{285}$ Consequently, relationships to banks may be more valuable for smaller PE groups with limited track record and reputation, allowing the following hypothesis:

\footnotetext{
${ }^{282}$ Cf. Boot (2000), p. 13f.

${ }^{283}$ Cf. Gârleanu/Zwiebel (2009), p. 749.

${ }^{284}$ Cf. Demiroglu/James (2010b), p. 317.

${ }^{285}$ Cf. Thakor (1996), p. 315.
} 
H12b: Smaller PE groups with banking relationship receive looser financial covenants than small PE groups without banking relationship

\subsubsection{Lead Arranger related}

\subsubsection{Organization}

Reputational and banking relationship components could have different effects in the cross-sectional comparison if the process of setting financial covenants is not identical from bank to bank. For instance, internal risk management divisions of banks may have veto rights during the negotiation of financial covenants, potentially reducing the reputational or banking relationship effect.

Another important factor for the restrictiveness of financial covenants could be the structure of certain lead arranging banks. If there is more than one lead arranging bank certain parts of negotiations are allocated to the lead arranging banks. For instance, one bank could be responsible for negotiating the credit agreement and another bank calculates financial covenants. However, all lead arranging banks finally agree on the terms and conditions of the loan. A last argument is that incentive structures of the lead arranging banks may differ fundamentally. While leveraged finance teams of investment banks, like Goldman Sachs, incentivize their employees with higher bonuses, based on fees for the firm, commercial banks, like e.g. Commerzbank, pay a higher share of fixed salary, which is not directly tied to fee origination. This difference in incentive structures may lead to relatively more or less deal pressure and willingness to give away better or worse loan terms. For instance, a leveraged loan team may have incentives to grant high leverage, loose covenants and other lax credit terms to a PE group just to make a deal shortly before the end of a bonus period. While these factors have an impact on the restrictiveness of financial covenants, it is difficult to formulate a hypothesis or to test it.

\subsubsection{Final Hold}

As shown in section 2.3.4, there is a principal agent relationship within the lender group in which the lead arranger acts on behalf of the syndicate participants. The lead 
arranger is better informed on the quality of the loan through due diligence and negotiation efforts. After the lead arranging bank has marketed the deal to the participants, the lead arrangers monitoring efforts are unobservable for the uninformed syndicate participants. Because monitoring is costly for the lead arranger, this may induce the lead arranger to reduce efforts.

HOLMSTRÖM/TIROLE (1997) theoretically argue that the lead arranger must retain a large financial stake in the borrowing company to ensure incentives for diligence and to signal own monitoring commitment. In the extreme scenario, the reputation of the lead arranger is sufficient financial capital. SUFI (2007) empirically tests the theoretical model, particularly how information asymmetry influences the syndicate structure. The article shows that, consistent with moral hazard problems in monitoring, lead banks retain a larger share of the loan and form a more concentrated syndicate when the borrower requires more intense monitoring and due diligence. Additionally, loan syndication is a repeat business and lead banks create a good reputation by accurately certifying loans. ${ }^{286}$ PANYAGOMETH/ROBERTS (2008) show by examining ex post debt rating changes that lead banks employ covenant design and reputation to mitigate agency conflicts, which supports the certification view of the lead bank's role. However, SUFI (2007) admits that 'lead bank reputation attenuates, but does not eliminate information asymmetry. ${ }^{287}$

Moral hazard may be minimized in equilibrium loan markets. However, 'overheated' markets, especially credit markets in the period from 2005 to 2007, may have been subject to market imperfections, creating potential for opportunistic behavior of market participants. The credit boom lured lower experienced, mostly institutional, lenders in the syndication market as documented by IVASHINA/SUN (2009). ${ }^{288}$ Lead arrangers may have expected these institutional investors to leave the market in normalized conditions reducing the reputational argument. In effect, the credit crisis exactly

\footnotetext{
${ }^{286}$ See for example Dennis/Mullineaux (2000), Lee/Mullineaux (2004).

${ }^{287}$ Cf. Sufi (2007), p. 629.

${ }^{288}$ Cf. Ivashina/Sun (2009).
} 
caused institutional investors to retreat from the leveraged loan market. ${ }^{289}$ Empirical evidence on this idea is scarce as the hardly observable information is mostly not available to researchers. Therefore, academic studies mostly rely on ex post performance of lenders.

BERNDT/GUPTA (2009) is one recent example testing this argument. They call the secondary syndicated loan market an 'originate-to-distribute' model, 'where banks can originate loans, earn their fees, and then distribute them to other investors in a largely opaque manner. ${ }^{290}$ They find that lenders, buying loans with an active secondary market, significantly underperform their peers by about $9 \%$ per year on a risk-adjusted basis over the three-year period after being traded in the secondary market. The underperformance is particularly pronounced for small, high-leverage lenders, like leveraged loan lenders, where moral hazard and adverse selection problems are more severe. The authors present two possible explanations: First, banks may knowingly originate 'lemons' to expand their origination fee based income since they are able to sell the loan to uninformed lenders (mostly non-bank financial institutions and hedge funds). Second, borrowers may lose the disciplining effect of bank monitoring and may be more likely to make suboptimal investment and operating decisions, which in turn leads to a negative long-run performance of lenders. ${ }^{291}$

Another way to test the idea of moral hazard in the overheated leveraged loan market is to relate creditor rights dilution to the final hold of the lead arranger. In contrast to financial covenants, which are an easily observable signal of credit quality, creditor rights dilution clauses are part of the complex credit agreement. Especially for nonfinancial institutional investors (or also government-backed banks in Germany that endeavored into the field of syndicated loans during the credit boom), these clauses are hardly observable without considerable effort. As one senior banker stated:

\footnotetext{
${ }^{289}$ Cf. Ivashina/Scharfstein (2008), p. 9f.

${ }^{290}$ Cf. Berndt/Gupta (2009), p. 726. For an explicit critique of the study see http://www.lsta.org/con tent.aspx?id=4598.

${ }^{291}$ Cf. Berndt/Gupta (2009), p. 728.
} 
'... in general we did not do covenant-lite deals. But what we accepted were clauses which reduced the severity of a covenant default. Therefore, when the headroom was already high, e.g. 30\%, highly reputable players asked us to integrate lender detrimental clauses. Participants often only looked at the headroom and were happy not knowing that the credit agreement contained clauses which alleviate the creditor rights in case of a covenant breach. Our credit committee of course knows of the details and consequently reduced the targeted final hold in this particular deal ...'

Therefore, the following hypothesis shall be tested:

H13: A lower share of the lead arranger's final hold relates to looser financial covenants

Additionally, the following related hypothesis on the relation between final hold and creditor rights dilution (CRD) will be tested:

H(CRD): A lower share of the lead arranger's final hold relates to a higher level of creditor rights dilution

\subsubsection{Macroeconomic related}

According to the model of AXELSON/STRÖMBERG/WEISBACH (2009) the structure of private equity funds will lead to investment distortions in the most efficient financing equilibrium. In good state economies, there will be overinvestment and in bad state economies there will be underinvestment. Consequently, PE investments will exhibit particularly large cyclicality. The model predicts that booming PE markets occur during periods of aggressive lending practices. They conclude that credit spreads should be negatively related to investment activity, transaction prices and leverage. Also, higher credit spreads should lead to more restrictive credit terms, i.e. tighter financial covenants. Besides this theoretical view, more practical considerations lead to the same conclusion. The prevailing credit risk spread mirrors the risk perception of the credit supply-side regarding future default risk. Favorable economic conditions imply lower probabilities of financial distress and thus potentially more relaxed fi- 
nancing terms. In the light of an economic downturn lenders might want to gain control faster over a potentially threatened firm. Vice versa, in boom times lenders might apply historical default rates to the future and therefore relax their demand for control rights. Empirical studies of AXELSON et al. (2010) and KAPLAN/STRÖMBERG (2009) confirm the relationship of deal activity and leverage to the macroeconomic environment. DEMIROGLU/JAMES (2010b) show that loan terms are affected by credit spreads. Therefore, the following hypothesis will be tested:

H14: Higher credit spreads lead to tighter financial covenants

\subsection{Summary}

The previous sections developed hypotheses on financial covenant restrictiveness. Hypotheses cover five main areas that influence the financing structure of LBOs, namely target, transaction, sponsor, lead arranger and macroeconomic related determinants. The individual hypotheses were developed by combining theoretical arguments with empirical findings in existing literature. Table 6 gives an overview of the hypotheses. In the following, these hypotheses will be tested in the empirical part of this thesis. 


\begin{tabular}{|c|c|c|c|c|}
\hline & & & \multicolumn{2}{|c|}{$\begin{array}{l}\text { Hypotheses on the Restrictiveness of } \\
\text { Financial Covenants }\end{array}$} \\
\hline & & & Expected influence & Empircal result \\
\hline \multicolumn{5}{|c|}{ Target related } \\
\hline & $\mathrm{H} 1$ & Size & - & ? \\
\hline & $\mathrm{H} 2 \mathrm{a} / \mathrm{b}$ & Growth & $\mathrm{a}:+/ \mathrm{b}:-$ & ? \\
\hline & H3 & Profitability & - & ? \\
\hline & $\mathrm{H} 4 \mathrm{a} / \mathrm{b}$ & Operating risk & $\mathrm{a}:+/ \mathrm{b}:-$ & ? \\
\hline & H5 & Tangibility & - & ? \\
\hline \multicolumn{5}{|c|}{ Transaction related } \\
\hline & H6 & Leverage & + & ? \\
\hline & H7 & Interest cost & - & ? \\
\hline & H8 & Maturity & + & ? \\
\hline & $\mathrm{H} 9 \mathrm{a} / \mathrm{b}$ & Share of bank debt & $\mathrm{a}:+/ \mathrm{b}:-$ & ? \\
\hline & H10 & Creditor rights dilution & + & ? \\
\hline \multicolumn{5}{|c|}{ Sponsor related } \\
\hline & $\mathrm{H} 11$ & Sponsor reputation & - & ? \\
\hline & $\mathrm{H} 12 \mathrm{a} / \mathrm{b}$ & Banking relationship & a: -/b: - & ? \\
\hline \multicolumn{5}{|c|}{ Lead arranger related } \\
\hline & H13 & Final hold & - & ? \\
\hline \multicolumn{5}{|c|}{ Macroeconomic } \\
\hline & $\mathrm{H} 14$ & Credit spread & + & ? \\
\hline+ & \multirow{2}{*}{\multicolumn{4}{|c|}{$\begin{array}{l}\text { Hypothesized positive relationship between the potential determinant and covenant restrictiveness } \\
\text { Hypothesized negative relationship between the potential determinant and covenant restrictiveness }\end{array}$}} \\
\hline- & & & & \\
\hline
\end{tabular}

Table 6: $\quad$ Hypotheses on the restrictiveness of financial covenants Source: Author 


\section{Empirical Study}

\subsection{Introductory Remarks}

The previous sections constructed the theoretical framework (section 3), presented types of financial covenants and expectations for differences in the covenant structure in sponsored and non-sponsored loans (section 4) and developed hypotheses on the determinants of financial covenant restrictiveness (section 5). This section tries to empirically answer the two main research questions of the thesis and constitutes the primary contribution to the body of knowledge. It first addresses the question if there are any differences in the covenant structures in sponsored and non-sponsored loans. Then, the proprietary dataset will be used to analyze the restrictiveness of financial covenants in LBOs. ${ }^{292}$

Before conceptualizing the empirical analysis, the author conducted 23 interviews with experts in the LBO lending market, i.e. lead arranging banks, PE groups, lawyers and gained firsthand experience of the covenant setting process and renegotiation of covenant breaches during internships at a leading bank and a prominent private equity investor.

\subsection{Datasets}

\subsubsection{LBO Sample}

The proprietary LBO sample was collected from the leveraged finance departments of three major European commercial banks. The query included all completed transactions for which these banks functioned as lead arrangers and co-lead arrangers, i.e. they were responsible for structuring the credit terms and conditions. Loan data was omitted when the bank did not finance the deal in the end or the supported private eq-

\footnotetext{
${ }^{292}$ This section was aggregated from two papers that were written during the author's research activity at the KfW Endowed Chair in Entrepreneurial Finance at Technische Universität München. The first paper Achleitner/Braun/Hinterramskogler/Tappeiner (2010): 'Structure and determinants of financial covenants in LBOs' can be obtained from SSRN and was presented at the EFM Symposium 2010 in Montreal. The second paper Achleitner/Braun/Tappeiner (2010): 'Private equity group reputation in leveraged buyouts - financing structure and lender control in Europe' is also available at SSRN. The author thanks three anonymous investment banks for the access to their confidential documents as well as Jerry Cao, Tim Jenkinson and Josh Lerner for invaluable comments.
} 
uity group did not win the deal. From all three banks, the author collected the following proprietary documents: ${ }^{293}$ the complete underwritten senior and subordinated loan contracts (text file), the original syndication memorandum (text file) and the underlying financial models (Excel file). Deals were excluded when the documents were not complete. To check the validity of the data, information that is also available in Dealscan was compared to the internal data from the banks. The provided documents were the relevant documents at transaction date, i.e. the closing day of the transaction. To secure consistency among documents and to reflect the ex ante expectation of the banks at origination date, potential post closing amendments were not taken into consideration.

The documents were screened for all relevant data including sources and uses of the transaction financing, historical $(\mathrm{t}=-3$ to $\mathrm{t}=-1)$, $\operatorname{actual}^{294}(\mathrm{t}=0)$, projected financial statements ( $t=1$ to $t=5)$, ownership structures, financial and non-financial covenants, and covenant clauses as well as other deal-related details.

In total, the author screened the credit documentation of 134 highly leveraged transactions in Germany, provided by three lead arranging banks ${ }^{295}$ from 2000 to 2008. Of these transactions, 130 were sponsored by 66 private equity groups, 4 were corporate takeovers and therefore omitted from the final sample. Similar to KAPLAN/ RUBACK (1995) the author includes 21 leveraged recapitalizations as they are identical to LBOs except that this type of transaction does not include the repurchase of the entire company's stock. ${ }^{296}$ Additionally, the authors' conversations with bankers reveal

\footnotetext{
${ }^{293}$ Disclosure rules in Germany are similar to disclosure rules in the US. Unless there are public securities outstanding, financial reports do not have to be filed. The disclosure of loan contracts is optional. LBO loan information, in particular financial covenants, is typically kept private.

${ }^{294}$ Underlying financial information at deal date is validated by auditors.

${ }^{295}$ As lead arrangers often act in a joint lead arranging consortium, there are deals included from additional 20 banks. For example, there is a deal included in the dataset where Goldman Sachs, Barclays, Unicredit, Commerzbank and RBS were joint mandated lead arrangers.

${ }^{296}$ Cf. Kaplan/Ruback (1995), p. 1068.
} 
that they do not perceive any difference in terms of deal structuring between sponsored LBOs and sponsored recapitalizations. ${ }^{297}$

As described, the LBO sample is based on data from three banks. Therefore, it is not a random sample and it is important to discuss potential selection issues. The author was granted access to the banks highly confidential credit documentation due to prior research relationships. The banks claimed that they did not filter their loans for the data aggregation. This notion is supported by the fact that several loans in the dataset were in default during the data aggregation process. As deals are often arranged by more than one bank, the sample includes deals from 23 different lead arranging banks and on average an LBO was arranged by 1.96 lead arrangers. The 66 different PE groups that sponsored the sample LBOs represent about $39 \%$ of all private equity members ${ }^{298}$ of the German PE and VC association (BVK e.V.).

The dataset contains seven deals where the private equity sponsor was bank-affiliated, e.g. Goldman Sachs Capital Partners (Principal Investment Area) is affiliated to Goldman Sachs \& Co. This is so far important as deals sponsored by PE groups with bank affiliation, where the bank also arranged the deal, receive on average better credit terms, i.e. pay lower interest margins and receive looser covenants. ${ }^{299}$ The dataset includes only three deals where the deal was sponsored by a PE group that is affiliated to the lead arranging bank. ${ }^{300}$

Panel A of Table 7 compares the sample (excluding recapitalizations) against several different benchmarks. It shows that the transactions in the dataset represent more than $40 \%$ of the total LBO transaction volume of the German buyout market between 2000 and 2008. ${ }^{301}$ Compared to the Western European market, the world's single largest private equity market, the sample covers about $6.7 \%$ of the Centre for Management

\footnotetext{
${ }^{297}$ Controlling for recapitalizations in the cross-sectional analysis does not change the reported results.

${ }^{298}$ Excluding sole VC members.

${ }^{299}$ Cf. Fang/Ivashina/Lerner (2010).

${ }^{300}$ The reported results are unaffected by the in- or exclusion of these deals.

${ }^{301}$ Transactions smaller than $€ 10$ million are omitted from the market volume. Transactions with an enterprise value of less than $€ 10$ million are mostly financed by government-backed banks and not financed by syndicated loans.
} 
Buy-Out Research (CMBOR) data and approx. $5.8 \%$ of the sample aggregated by Strömberg (2008) in the same period.

Panel B benchmarks the distribution of deal types in the sample with those of the global, Western European and German private equity market in the covered period. ${ }^{302}$ While much of the existing literature focuses on public-to-private (P2P) transactions, the low share in the sample ( $1.8 \%$ in terms of deal numbers) is representative for Western European (2.4\%) and German (1.5\%) private equity activity. However, the sample share is lower when compared to the global sample (6.8\%) of STRÖMBERG (2008). The difference is that in Germany there are less publicly listed companies and regulatory hurdles, e.g. there has been no formal implementation of a squeeze out rule before $2002 / 2006 .^{303}$

The majority of deals in the sample consists of divisional buyouts (35.8\%) and privateto-private buyouts (34.9\%). Although the individual shares of these two private buyout types deviate from the various benchmark samples, the aggregate share (70.7\%) is in line with the benchmarks (73.2\% Global, 84.2\% Western Europe, 71.8\% Germany). The dataset oversamples secondary transactions in this study (26.6\%) in comparison to the benchmarks (16.8\% Global, 14.8\% Western Europe, 13.2\% Germany). There is no reason known to the author why an oversampling of secondary buyouts should influence the results. Overall, the sample seems quite representative for the German but also the Western European and global private equity market.

\footnotetext{
${ }^{302}$ The Strömberg (2008) sample is only available from 2001 to 2007.

${ }^{303}$ In 2002, the 'aktienrechtliche Squeeze-out' has been introduced while in 2006, the 'übernahmerechtliche Squeeze-out' has been introduced.
} 
Panel A: Sample coverage

\begin{tabular}{|c|c|c|c|c|c|}
\hline \multirow[t]{2}{*}{ Deal year } & \multirow[t]{2}{*}{$\begin{array}{r}\text { No. of } \\
\text { transaction }\end{array}$} & EV & \multicolumn{3}{|c|}{ Sample coverage $(\mathrm{EV})$ of } \\
\hline & & (€ millions) & $\begin{array}{l}\text { Germany } \\
(C M B O R\end{array}$ & $\begin{array}{l}\text { Western } \\
\text { Europe }\end{array}$ & $\begin{array}{l}\text { Western } \\
\text { Europe }\end{array}$ \\
\hline 2000 & 1 & 77 & $0.4 \%$ & $0.1 \%$ & $0.1 \%$ \\
\hline 2001 & 2 & 3,366 & $42.3 \%$ & $5.4 \%$ & $5.4 \%$ \\
\hline 2002 & 6 & 4,874 & $51.4 \%$ & $7.3 \%$ & $6.7 \%$ \\
\hline 2003 & 7 & 3,197 & $24.1 \%$ & $4.9 \%$ & $4.7 \%$ \\
\hline 2004 & 17 & 13,838 & $67.5 \%$ & $16.8 \%$ & $11.6 \%$ \\
\hline 2005 & 19 & 8,769 & $60.5 \%$ & $6.8 \%$ & $4.6 \%$ \\
\hline 2006 & 26 & 6,792 & $27.8 \%$ & $4.0 \%$ & $2.6 \%$ \\
\hline 2007 & 24 & 13,947 & $52.7 \%$ & $8.1 \%$ & $8.2 \%$ \\
\hline 2008 & 7 & 2,756 & $42.9 \%$ & $7.4 \%$ & NA \\
\hline Total & 109 & 57,540 & $40.2 \%$ & $6.7 \%$ & approx. $5.8 \%$ \\
\hline
\end{tabular}

Panel B: Benchmarking by type of deal

\begin{tabular}{|c|c|c|c|c|c|}
\hline Buyout type & $\begin{array}{c}\text { Sample } \\
\text { number of } \\
\text { transaction }\end{array}$ & $\begin{array}{c}\text { Sample } \\
\text { share }\end{array}$ & $\begin{array}{c}\text { Germany } \\
\text { 2000-2008 } \\
(C M B O R \\
2009)\end{array}$ & $\begin{array}{c}\text { Westem } \\
\text { Europe } \\
\text { 2000-2008 } \\
(C M B O R \\
2009)\end{array}$ & $\begin{array}{c}\text { Global } \\
\text { 2001-2007 } \\
\text { (Strömberg } \\
\text { 2008) }\end{array}$ \\
\hline Divisional & 39 & $35.8 \%$ & $54.0 \%$ & $39.6 \%$ & $36.3 \%$ \\
\hline Private-to-privat & 38 & $34.9 \%$ & $17.8 \%$ & $44.6 \%$ & $36.9 \%$ \\
\hline Public-to-private & 2 & $1.8 \%$ & $1.5 \%$ & $2.4 \%$ & $6.8 \%$ \\
\hline Secondary & 29 & $26.6 \%$ & $13.2 \%$ & $14.8 \%$ & $16.8 \%$ \\
\hline Other & 1 & $0.9 \%$ & $13.4 \%$ & $13.2 \%$ & $3.2 \%$ \\
\hline
\end{tabular}

Table 7: $\quad$ Sample coverage and benchmarking

Source: $\quad$ LBO dataset, CMBOR 2009, STRÖMBERG (2008)

It is important to highlight that Germany represents a fruitful institutional setting to understand covenants. In particular, the importance of shifting control rights is directly linked to the ability to force companies into bankruptcy or reorganization following a 
default. ${ }^{304}$ This ability heavily depends on the institutional setting. For creditors a default in a country with strong creditor rights, such as Germany, is of a less deterrent than in a country with weaker creditor rights. ${ }^{305}$ German insolvency law prescribed an auction-based process that favors liquidation over reorganization. ${ }^{306}$ By contrast, the US mostly applies Chapter 11 of the bankruptcy code that can be described as a structured bargaining process. ${ }^{307}$ The relatively strong position of the judge and the management in the decision process reduces the legal rights of the creditors. ${ }^{308}$ Following this line of argument, the violation of a financial covenant, which triggers a default of the loan, is economically more valuable for a creditor under German law than under US bankruptcy law. Consequently, financial covenants should be of higher importance in countries with stronger creditor rights implying rigorous negotiations and ex-ante strict contracts. Supporting this argument, HONG/HUNG/ZHANG (2009) find that financial covenants are especially important in countries with strong creditor rights. For this reason the German jurisdiction provides a very interesting setting to explore the structure and determinants of financial covenants in LBOs.

Table 8 presents statistics on the size, pricing and capital structure of the transactions. The bottom panel reports time trends for the variables across the following three periods which approximate the private equity cycle: 2000 to 2003 (pre credit boom), 2004 to 2007 (credit boom) and 2008 (post credit boom). The author tests the significance of the time trends with Wilcoxon rank-sum tests.

The sample contains relatively large deals: The median LBO enterprise value (EV) is $€ 230.5$ million compared to the median €42.4 million reported in Capital IQ. ${ }^{309}$ The median deal is priced at an EV to EBITDA multiple of 6.9. Clearly, the majority of the

\footnotetext{
${ }^{304}$ Cf. Lerner/Stromberg/Sorensen (2009), p. 72 .

${ }^{305}$ Cf. La Porta, et al. (1997), Allen/Bartiloro/Kowalewski (2006), Djankov/McLiesh/Shleifer (2007).

${ }^{306}$ Cf. Aghion/Hart/Moore (1992), p. 527.

${ }^{307}$ Cf. Aghion/Hart/Moore (1992).

${ }^{308}$ The detailed country-specific classification of Djankov/McLiesh/Shleifer (2007) was not available to the authors.

${ }^{309}$ As reported by Strömberg (2008). The author converts the 2007 US dollar values with the yearly average exchange rate of 1.36775 .
} 
buyout price is financed with debt: The median deal shows a D/EBITDA multiple of 4.3 and the equity contribution amounts to $33.5 \%$. Across time, the data shows the typical boom and bust pattern although the trends are not always statistically significant. Debt (equity) levels increase (decrease) during the boom time 2004-2007 while they decrease (increase) with the financial crises in 2008.

Overall, these pricing and capital structure statistics are broadly in line with recent work by AXELSON et al. (2010). They report a median EV/EBITDA of 7.6x, a median D/EBITDA of 5.2x and a median D/EV of $70.0 \%$ for 1,142 worldwide LBOs. Although being reasonably close to this sample, when conditioning their sample on the Western Europe setting and the proprietary focus on private-to-private transactions (i.e. deals which are usually undersampled in commercial databases due to their lower visibility), their pricing and capital structure statistics are almost identical to the present dataset.

The rich nature of the proprietary data allows a detailed picture of the financing terms of the debt package. Debt in buyouts includes senior and subordinated financing for which separate credit agreements regulate the claims of the lenders against the borrower. ${ }^{310}$ Covenants as the primary unit of analysis in this thesis are commonly more restrictive in senior credit agreements in order to enable senior lenders to receive control rights in advance of subordinated claims. Hence, the covenant analysis will be based on the senior debt package. ${ }^{311}$ Table 9 reports spreads and maturities of senior as well as subordinated tranches. Additionally, it shows the all-in-drawn spread, i.e. the spread of all tranches weighted by the facility amount, the all-in-drawn senior spread, i.e. the spread of all senior tranches weighted by the facility amount, as well as the credit risk spread, defined as the spread difference between BB and AAA corporate bonds.

\footnotetext{
${ }^{310}$ Senior debt includes A, B, C term loans, a revolving credit facility and a capex facility (see section 2.3.1). Revolving credit facility and capex facility have the same terms as Term A loans and are therefore not included in the table. Subordinated debt comprehends second lien notes and mezzanine financing.

311 The spreads for the subordinated tranches show more variation than the senior tranches. The maturities for the subordinated tranches are longer than for senior tranches and are highly standardized.
} 


\begin{tabular}{|c|c|c|c|c|c|c|c|}
\hline \multirow[t]{2}{*}{ Deal year } & \multirow[t]{2}{*}{ Statistics } & \multirow[t]{2}{*}{$\begin{array}{l}\text { No. of } \\
\text { transaction } \\
\text { s }\end{array}$} & \multirow{2}{*}{$\begin{array}{c}\text { Transaction } \\
\text { total capital } \\
\text { (€ millions) } \\
\end{array}$} & \multirow[t]{2}{*}{$\begin{array}{l}\text { Transaction } \\
\text { value to } \\
\text { EBITDA } \\
\text { multiple } \\
x\end{array}$} & \multirow[t]{2}{*}{$\begin{array}{c}\text { Net debt to } \\
\text { EBITDA) } \\
\\
x\end{array}$} & \multirow{2}{*}{$\begin{array}{c}\text { Net senior } \\
\text { debt to } \\
\text { EBITDA } \\
x \\
x \\
\end{array}$} & \multirow{2}{*}{$\begin{array}{c}\begin{array}{c}\text { Equity } \\
\text { contribution }\end{array} \\
\% \text { of total capital }\end{array}$} \\
\hline & & & & & & & \\
\hline 2000 & Median & 1 & 65.0 & 6.5 & 3.9 & 3.4 & 33.1 \\
\hline 2001 & Median & 2 & 1493.6 & 5.9 & 3.6 & 3.1 & 37.6 \\
\hline 2002 & Median & 6 & 332.3 & 7.7 & 3.9 & 3.5 & 46.6 \\
\hline 2003 & Median & 7 & 55.4 & 4.7 & 3.3 & 2.3 & 43.1 \\
\hline 2004 & Median & 20 & 705.0 & 7.3 & 4.6 & 3.6 & 30.4 \\
\hline 2005 & Median & 28 & 252.5 & 7.0 & 4.3 & 3.6 & 27.7 \\
\hline 2006 & Median & 30 & 123.6 & 6.6 & 4.4 & 3.6 & 32.6 \\
\hline 2007 & Median & 29 & 202.0 & 7.6 & 4.8 & 4.1 & 33.1 \\
\hline 2008 & Median & 7 & 273.1 & 7.9 & 4.1 & 3.2 & 37.5 \\
\hline Total & Median & 130 & 230.5 & 6.9 & 4.3 & 3.6 & 33.5 \\
\hline \multicolumn{8}{|c|}{ Time trends: } \\
\hline \multicolumn{3}{|c|}{ Pre credit boom (00-03) vs. credit boom (04-07) } & $(-)$ & $(+)$ & $(+)^{* *}$ & $(+)^{* * *}$ & $(-) * * *$ \\
\hline \multicolumn{3}{|c|}{ Credit boom (04-07) vs. post credit boom (08) } & $(+)$ & $(-)$ & $(-)$ & $(-)$ & $(+)^{* * * *}$ \\
\hline \multicolumn{3}{|c|}{ Pre credit boom (00-03) vs. post credit boom (08) } & $(+)$ & $(+)$ & $(+)^{*}$ & $(+)$ & $(+)$ \\
\hline \multicolumn{8}{|c|}{$\begin{array}{c}()^{*} \text { : at the } 10 \% \text { significance level } \\
()^{* *} \text { at the } 5 \% \text { significance level } \\
()^{* * *} \text { at the } 1 \% \text { significance level }\end{array}$} \\
\hline
\end{tabular}

Table 8: $\quad$ Size, pricing and capital structure of the sample over time Source: $\quad$ LBO dataset

Table 9 and Table 10 document that spreads and maturities are remarkably homogenous for senior debt tranches. In the cross section, 65\% (93\%) of the deals have a Term A spread of 2.25\% (between 2.0 and 2.5\%) and $82 \%$ have a Term A maturity of 84 months. Over time, the median Term A spread varies in a statistical sense over the three observation periods. ${ }^{312}$ But the respective median values of 2.25, 2.25 and 2.5 highlight that the changes are small in economic terms. Similarly, the respective median Term A maturity is fairly stable over time in economic terms. These patterns hold for all senior debt tranches. The high uniformity in pricing is remarkable. If one assumes a set of companies with the same financial but different total risk (e.g. due to industry-specific cash flow dynamics), one would expect lenders to charge these dif-

312 The observation periods are 2000-2003, 2004-2007 and 2008, respectively. 
ferent companies different loan prices. Conversely, according to the studies of DEMIROGLU/JAMES (2010b) and IVASHINA/KOVNER (2010) the interest rates for leveraged loans in the US show considerable variation.

There are several possible explanations for this finding. For instance, banks reduce the amount of debt they hold in their own books and pass on a larger share to other banks and institutional investors. Another reason may be that the European leveraged loan market may be not efficient to set interest rates as argued by POLENBERG/LUKATSKY/GUPTE (2010). A reason for this less efficient market structure might be the oligopolistic investment banking industry in Europe as opposed to the more competitive structure in the US. KAPLAN/STEIN (1993) proposed another explanation for the low variation in interest costs for the early US buyout market: The relatively little variation in loan prices may be offset by variations in 'non-price terms of credit' which may be used by lenders to adjust their risk-return payoff. ${ }^{313}$ The unit of analysis of this thesis, i.e. covenants, represents one (if not the) central class of such non-price credit terms.

Another interesting point to mention is that second lien ( $2^{\text {nd }}$ lien) tranches only appear during boom periods (here 2004 to 2007) as also noted by DEMIROGLU/JAMES (2010b). Of the seven deals in 2008, none included a second lien tranche. Looking at the terms of the second lien tranches shows that they have higher margins (50bps to Term C) and maturities (6 months to Term C) than the first-lien tranches but lower margins and maturities than the subordinated debt tranches, which mirrors the claim structure.

Notably, subordinated spreads exhibit significantly decreasing cash spreads during the boom phase, while the payment-in-kind ${ }^{314}$ (PIK) spread increases. Increasingly utilized noncash interest payments in booming credit markets were already observed by KAPLAN/STEIN (1993). Another way to defer interest payments are PIK toggles, which give the borrowers the option to defer cash interest by adding it to outstanding principal. In contrast to the US market, for which DEMIROGLU/JAMES (2010b) re-

\footnotetext{
${ }^{313}$ Cf. Kaplan/Stein (1993), p. 332.

${ }^{314}$ Payment-in-kind (PIK) means that interest is not paid in cash but via the issuance of additional debt.
} 
port that circa $20 \%$ of their buyouts include PIK toggles, the European LBO market appears to be more conservative regarding cash interest deferrals. Only one transaction in the sample, which took place in 2006, includes a PIK toggle ${ }^{315}$ in their subordinated loans.

In line with the model on the structure of debt contracts for highly levered borrowers by DIAMOND (1993), the sample shows that shorter term debt is senior to longer term debt. Interestingly, maturities exhibit a similarly homogenous structure as senior loan spreads. For example, out of the 123 Term A loans, 101 have a maturity of 84 months, i.e. seven years.

${ }^{315}$ Toggle refers to the option to convert cash payments to PIK payments. 


\begin{tabular}{|c|c|c|c|c|c|c|c|c|c|}
\hline Deal year & Statistics & $\begin{array}{c}\text { Maturity } \\
\text { term A } \\
\text { loans } \\
\text { (months) }\end{array}$ & $\begin{array}{c}\text { Spread } \\
\text { term A } \\
\text { loans } \\
\text { (as \%) } \\
\end{array}$ & $\begin{array}{c}\text { Maturity } \\
\text { term B } \\
\text { loans } \\
\text { (months) }\end{array}$ & $\begin{array}{c}\text { Spread } \\
\text { term B } \\
\text { loans } \\
\text { (as \%) }\end{array}$ & $\begin{array}{c}\text { Maturity } \\
\text { term C } \\
\text { loans } \\
\text { (months) } \\
\end{array}$ & $\begin{array}{c}\text { Spread } \\
\text { term C } \\
\text { loans } \\
\text { (as \%) } \\
\end{array}$ & $\begin{array}{c}\text { Maturity } \\
\text { second lien } \\
\text { loans } \\
\text { (months) }\end{array}$ & $\begin{array}{c}\text { Spread } \\
\text { second lien } \\
\text { loans } \\
\text { (as \%) }\end{array}$ \\
\hline 2000 & $\begin{array}{c}\text { Median } \\
\text { n }\end{array}$ & $\begin{array}{c}72.0 \\
1\end{array}$ & $\begin{array}{c}2.50 \\
1\end{array}$ & $\begin{array}{c}84.0 \\
1\end{array}$ & $\begin{array}{c}3.00 \\
1\end{array}$ & & & & \\
\hline 2001 & $\begin{array}{c}\text { Median } \\
\mathrm{n}\end{array}$ & $\begin{array}{c}84.0 \\
2\end{array}$ & $\begin{array}{c}2.25 \\
2\end{array}$ & $\begin{array}{c}96.0 \\
2\end{array}$ & $\begin{array}{c}2.75 \\
2\end{array}$ & $\begin{array}{c}108.0 \\
2\end{array}$ & $\begin{array}{c}3.38 \\
2\end{array}$ & . & . \\
\hline 2002 & $\begin{array}{c}\text { Median } \\
\mathrm{n}\end{array}$ & $\begin{array}{c}84.0 \\
6\end{array}$ & $\begin{array}{c}2.25 \\
6\end{array}$ & $\begin{array}{c}96.0 \\
6\end{array}$ & $\begin{array}{c}2.75 \\
6\end{array}$ & $\begin{array}{c}108.0 \\
3\end{array}$ & $\begin{array}{c}3.25 \\
3\end{array}$ & . & . \\
\hline 2003 & $\begin{array}{c}\text { Median } \\
\mathrm{n}\end{array}$ & $\begin{array}{c}84.0 \\
7\end{array}$ & $\begin{array}{c}2.50 \\
7\end{array}$ & $\begin{array}{c}96.0 \\
5\end{array}$ & $\begin{array}{c}2.75 \\
5\end{array}$ & $\begin{array}{c}108.0 \\
3\end{array}$ & $\begin{array}{c}3.25 \\
3\end{array}$ & . & . \\
\hline 2004 & $\begin{array}{c}\text { Median } \\
\mathrm{n}\end{array}$ & $\begin{array}{c}84.0 \\
20\end{array}$ & $\begin{array}{c}2.25 \\
20\end{array}$ & $\begin{array}{c}96.0 \\
19\end{array}$ & $\begin{array}{c}2.75 \\
19\end{array}$ & $\begin{array}{c}108.0 \\
18\end{array}$ & $\begin{array}{c}3.25 \\
18\end{array}$ & $\begin{array}{c}114.0 \\
3\end{array}$ & $\begin{array}{c}5.50 \\
4\end{array}$ \\
\hline 2005 & $\begin{array}{c}\text { Median } \\
\mathrm{n}\end{array}$ & $\begin{array}{c}84.0 \\
28\end{array}$ & $\begin{array}{c}2.25 \\
28\end{array}$ & $\begin{array}{c}96.0 \\
28\end{array}$ & $\begin{array}{c}2.75 \\
28\end{array}$ & $\begin{array}{c}108.0 \\
25\end{array}$ & $\begin{array}{c}3.25 \\
25\end{array}$ & $\begin{array}{c}114.0 \\
11\end{array}$ & $\begin{array}{c}5.50 \\
10\end{array}$ \\
\hline 2006 & $\begin{array}{c}\text { Median } \\
\mathrm{n}\end{array}$ & $\begin{array}{c}84.0 \\
27\end{array}$ & $\begin{array}{c}2.25 \\
27\end{array}$ & $\begin{array}{c}96.0 \\
29\end{array}$ & $\begin{array}{c}2.75 \\
29\end{array}$ & $\begin{array}{c}108.0 \\
18\end{array}$ & $\begin{array}{c}3.06 \\
18\end{array}$ & $\begin{array}{c}114.0 \\
6\end{array}$ & $\begin{array}{c}4.75 \\
6\end{array}$ \\
\hline 2007 & $\begin{array}{c}\text { Median } \\
\mathrm{n}\end{array}$ & $\begin{array}{c}84.0 \\
25\end{array}$ & $\begin{array}{c}2.25 \\
25\end{array}$ & $\begin{array}{c}96.0 \\
29\end{array}$ & $\begin{array}{c}2.75 \\
29\end{array}$ & $\begin{array}{c}108.0 \\
20\end{array}$ & $\begin{array}{c}3.19 \\
20\end{array}$ & $\begin{array}{c}114.0 \\
9\end{array}$ & $\begin{array}{c}4.50 \\
8\end{array}$ \\
\hline 2008 & $\begin{array}{c}\text { Median } \\
\mathrm{n}\end{array}$ & $\begin{array}{c}84.0 \\
7 \\
\end{array}$ & $\begin{array}{c}2.50 \\
7 \\
\end{array}$ & $\begin{array}{c}96.0 \\
7 \\
\end{array}$ & $\begin{array}{c}3.00 \\
7 \\
\end{array}$ & $\begin{array}{c}108.0 \\
7 \\
\end{array}$ & $\begin{array}{c}3.50 \\
7 \\
\end{array}$ & . & . \\
\hline Total & $\begin{array}{c}\text { Median } \\
\text { n }\end{array}$ & $\begin{array}{c}84.0 \\
123\end{array}$ & $\begin{array}{l}2.25 \\
123\end{array}$ & $\begin{array}{l}96.0 \\
126\end{array}$ & $\begin{array}{l}2.75 \\
126\end{array}$ & $\begin{array}{c}108.0 \\
96\end{array}$ & $\begin{array}{c}3.25 \\
96\end{array}$ & $\begin{array}{c}114.0 \\
29\end{array}$ & $\begin{array}{c}4.75 \\
28\end{array}$ \\
\hline $\begin{array}{l}\text { Time tre } \\
\text { Pre credit } \\
\text { Credit boo } \\
\text { Pre credit }\end{array}$ & $\begin{array}{l}\text { boom (04-07) } \\
\text { tboom (08) } \\
\text { redit boom (08) }\end{array}$ & $\begin{array}{c}(+)^{* *} \\
(+) \\
(+)\end{array}$ & $\begin{array}{c}(-)^{* * *} \\
(+)^{* * *} \\
(+)^{*}\end{array}$ & $\begin{array}{l}(+) \\
(-) \\
(+)\end{array}$ & $\begin{array}{l}(-)^{* * *} \\
(+)^{* * *} \\
(+)^{* * *}\end{array}$ & $\begin{array}{c}(+) \\
(-) \\
0\end{array}$ & $\begin{array}{c}(-)^{* *} \\
(+)^{* * *} \\
(+)^{* * *}\end{array}$ & $\begin{array}{l}\text { n.m. } \\
\text { n.m. } \\
\text { n.m. }\end{array}$ & $\begin{array}{l}\text { n.m. } \\
\text { n.m. } \\
\text { n.m. }\end{array}$ \\
\hline
\end{tabular}

Table 9:

Terms of the debt tranches I/II

Source:

LBO dataset 


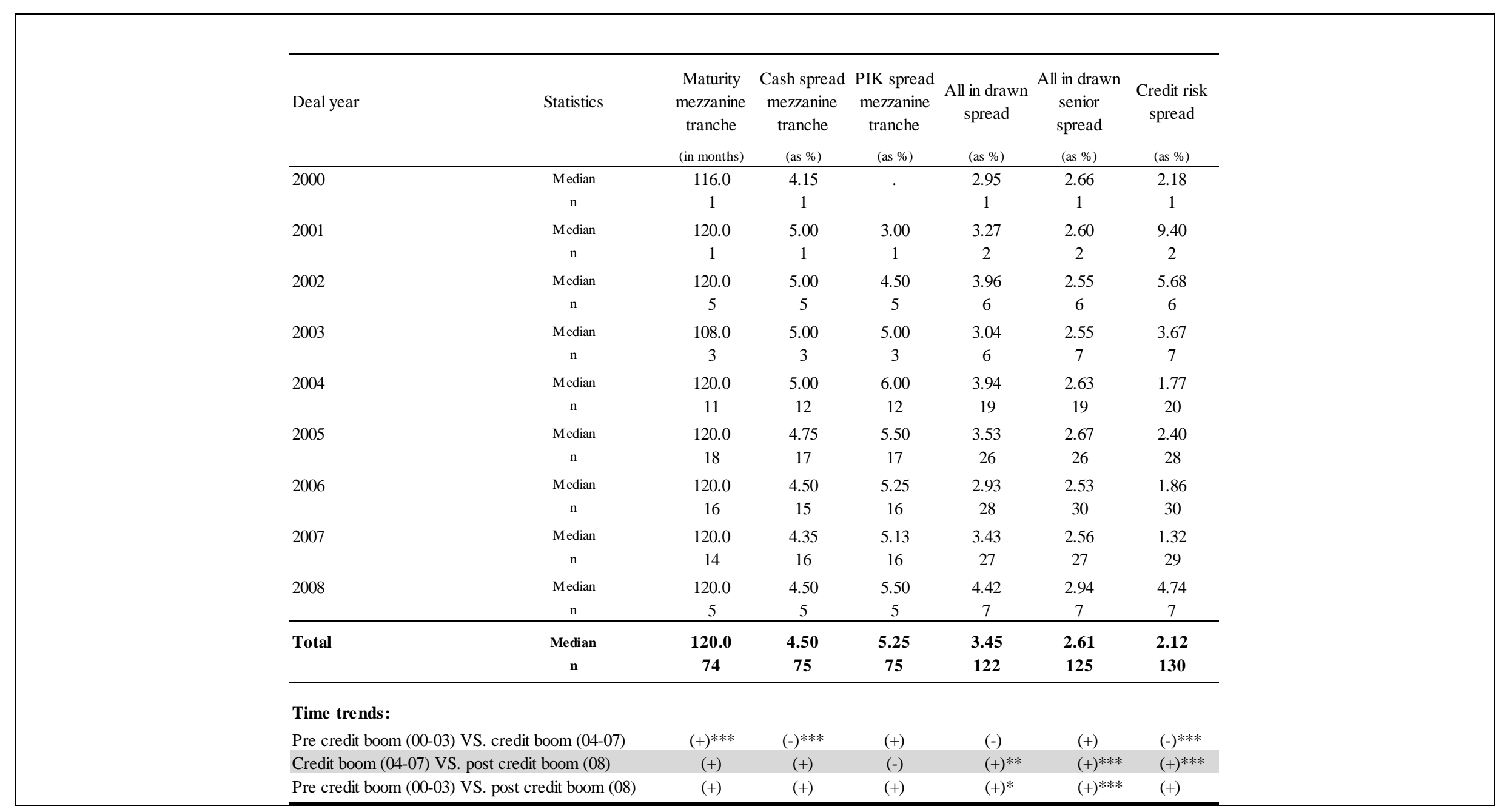

Table 10: Source:
Terms of the debt tranches II/II LBO dataset 


\subsubsection{Benchmark Sample}

In order to evaluate the covenant menu of sponsored loans, this section constructs benchmark samples of non-sponsored loans from Reuters' LPC Dealscan database (Dealscan). Dealscan reports comprehensive information on syndicated loan deals, including the name and location of the borrower, the names of all lender parties, the type, purpose, amount, contract date of the loan and information on price terms. Additionally, Dealscan is the only database that reports the set of covenants and their respective thresholds. CAREY/POST/SHARPE (1998) assess potential limitations of Dealscan. They report that LPC collects a large share of the data directly from the original credit agreements drawn from SEC filings. In recent years, Dealscan enriched the SEC filings with publicly available data from internet sources or through LPC's relationships with major banks. This results in a database of mostly US medium to large loans. Besides this limitation, Dealscan does not seem to expose a systematic bias in the loan selection. ${ }^{316}$

However, IVASHINA/KOVNER (2010) mention that the covenant information of Dealscan is limited. For example, there is no indication on the financial forecast and one cannot distinguish between covenant-lite and missing covenant information. Nevertheless, Dealscan is the best available database to analyze covenant information.

Each loan deal usually consists of several facilities. For example, a typical deal contains a term loan and a 364-revolving credit line. While certain credit characteristics, such as interest spreads, are set at the individual facility level, covenants are determined at the loan deal level. ${ }^{317}$ Hence, the analysis focuses at the deal level. The author consolidates facility specific credit characteristics, such as interest spreads, to the deal level by weighting them with the facility size.

The aim is to construct benchmarks which mirror the loan deal characteristics (i.e. the loan purpose and facilities) of the sponsored loan packages closely. Therefore, two samples are constructed. The primary sample consists of all non-sponsored loan pack-

\footnotetext{
${ }^{316}$ Cf. Carey/Post/Sharpe (1998), p. 851.

${ }^{317}$ E.g. Bradley/Roberts (2004) or Demerjian (2010).
} 
ages which include term loan facilities since these facilities provide the majority of debt financing in buyouts. ${ }^{318}$ In addition to this primary sample, an alternative benchmark sample is constructed which includes exclusively non-sponsored loan deals (including term loans) for the purpose of corporate acquisitions.

The sample includes deals with covenant information from Dealscan in the period of 2000 to 2008. Since the aim is to control for financial risk, the author conditions both samples on the availability of Compustat data for the borrower. ${ }^{319}$ This results in 1,423 deal observations for the term loan sample and 795 observations for the acquisition sample. The term loan sample is selected as the primary benchmark since it contains more observations for the analysis. The results are, however, stable across both benchmark samples.

In terms of comparability, Table 11 reports the main characteristics of the sponsored and non-sponsored loans. It shows that the median borrower of a non-sponsored loan (€370.5 million sales, €58.1 EBITDA) is larger than the median size of a firm that is acquired with the help of sponsored loans ( $€ 276.4$ million sales, $€ 34.9$ million EBITDA). In terms of financial risk, the borrowers of sponsored loans are exposed to considerably higher D/EV (median 66.4\%) and D/EBITDA (median 5.35x) ${ }^{320}$ levels as compared to traditional corporate borrowers (D/EV 33.0\%, D/EBITDA 2.87x). The median size of the loan package is similar in sponsored (€178.5 million) and nonsponsored loans ( $€ 171.6$ million). The median weighted spread of 265 bps of sponsored loans is higher than the median weighted spread of $163 \mathrm{bps}$ for non-sponsored loans. Interestingly, the median weighted maturity of 84 months for sponsored loans is more than double as long as the weighted maturity of 36 months for non-sponsored loans. However, this is mainly driven by the fact that non-sponsored loans contain almost always a revolving credit facility with 12 or 24 months expiration time, after which it is expected to be renewed. In sponsored loans, the revolving credit facility has

\footnotetext{
${ }^{318}$ Cf. Axelson, et al. (2010).

${ }^{319}$ In particular, the author matches the borrowers to Compustat data via both the company names and tickers provided by Dealscan. Compustat aggregates financials of publicly listed firms.

${ }^{320}$ This is the maximum leverage level, i.e. with drawn revolver as the financial risk of corporate borrowers also includes partly drawn revolvers.
} 
the same maturity as the term A tranche. Overall, the characteristics of sponsored and non-sponsored loans indicate that the two groups are relatively comparable.

\begin{tabular}{|c|c|c|c|c|c|c|c|}
\hline \multirow[t]{3}{*}{ Variables } & \multirow[t]{3}{*}{ Unit } & \multicolumn{3}{|c|}{ Sponsored loans } & \multicolumn{3}{|c|}{ Non-sponsored loans } \\
\hline & & & & & & All & \\
\hline & & Obs. & Mean & Median & Obs. & Mean & Median \\
\hline \multicolumn{8}{|l|}{ Size } \\
\hline Sales & mio. $€$ & 129 & 568.6 & 276.4 & 1,420 & 1686.1 & 370.5 \\
\hline EBITDA & mio. $€$ & 129 & 75.5 & 34.9 & 1,359 & 261.9 & 58.1 \\
\hline \multicolumn{8}{|l|}{ Financial risk } \\
\hline D/EV & \# & 129 & $65.4 \%$ & $66.4 \%$ & 1,423 & $36.7 \%$ & $33.0 \%$ \\
\hline D/EBITDA & $\#$ & 129 & 5.48 & 5.35 & 1,295 & 3.5 & 2.9 \\
\hline \multicolumn{8}{|l|}{ Loan Characteristics } \\
\hline Loan package & mio. $€$ & 129 & 422.9 & 178.5 & 1,332 & 621.8 & 171.6 \\
\hline Weighted Spread & basis points & 129 & 267.4 & 265.1 & 1,332 & 192.6 & 162.5 \\
\hline Weighted Maturity & months & 126 & 82.3 & 84.0 & 783 & 40.7 & 36.0 \\
\hline
\end{tabular}

Table 11: Characteristics of sponsored and non-sponsored loans Source: $\quad$ LBO dataset, Dealscan

\subsection{Financial Covenants in Sponsored versus Non-sponsored Loans}

\subsubsection{Types and Combinations of Financial Covenants}

As shown in section 3 and 4, financial covenants constitute limits on the level of accounting figures expressed in both, relative and absolute value. In transactions with senior and subordinated financing, there are two credit agreements which regulate the claims of the lenders against the borrower and an intercreditor agreement that regulates the claims between senior and subordinated lenders. While both the senior and the subordinated credit agreement include separate financial covenants, senior debt covenants are commonly more restrictive in order to enable senior lenders to receive control rights in advance of subordinated claims. Financial covenant restrictiveness - in contrast to the mere inclusion of covenants - is typically not standardized and is subject to negotiation between borrowers and intermediaries or lenders. 
Leveraged loans traditionally incorporate maintenance covenants. However, in overheated credit markets leveraged loans might incorporate incurrence covenants instead of maintenance covenants. The structure including incurrence covenants only is known as 'covenant-lite' deals in leveraged buyouts. Table 12 and Table 13 reports the inclusion of separate covenants in sponsored loans and the respective benchmark of nonsponsored loans. The Wilcoxon tests on the right side of the table refer to the differences between the sponsored loan sample and (a) the entire sample of non-sponsored loans and (b) the highest (fourth) D/EV quartile of the non-sponsored sample.

The classification of covenants is based on Dealscan and discussions with industry experts. The analysis considers the following seven financial covenants: (1) debt to EBITDA (D/EBITDA), (2) EBITDA to interest (EBITDA/I), (3) unlevered cash flow to debt service (CashFlowCoverage), (4) Capex, (5) Net Worth, (6) debt to equity (D/E) and (7) Current Ratio covenants. The data shows that sponsored loans focus on the first four of these seven covenants, i.e. D/EBITDA ${ }^{321}$, EBITDA/I, CashFlowCoverage and Capex restrictions. These covenants are included in almost all sponsored loan agreements $(97.0 \%, 79.8 \%, 96.9 \%$ and $74.4 \%)$ but only in roughly half of the non-sponsored loan agreements $(71.3 \%, 45.6 \%, 55.5 \%$ and $40.4 \%$ ), with the D/EBITDA covenant being the most frequently used covenant. Indeed, sponsored loans include no further covenant types whereas some non-sponsored loans include Net Worth (28.7\%), D/E (15.2\%) and Current Ratio (5.5\%) covenants. The differences in the inclusion frequencies between the sponsored and non-sponsored sample are statistically significant for all seven covenant types.

Panel B reports the development of the covenant structures over time. Although there is some variation over time, the basic patterns seem to be relatively stable across different economic time periods.

${ }^{321}$ The author includes Senior D/EBITDA in the D/EBITDA category of covenants. 


\begin{tabular}{|c|c|c|c|c|c|c|c|c|c|c|c|c|}
\hline \multirow[t]{3}{*}{ Variables } & \multirow[t]{3}{*}{ Unit } & \multicolumn{3}{|c|}{ Sponsored loans } & \multicolumn{3}{|c|}{ Non-sponsored loans } & \multirow{2}{*}{\multicolumn{3}{|c|}{$\begin{array}{c}\text { Non-sponsored loans } \\
\text { Highest Leverage Quartile }\end{array}$}} & \multicolumn{2}{|c|}{$\begin{array}{l}\text { Diff. test } \\
\text { (Wilcoxon) }\end{array}$} \\
\hline & & \multirow[b]{2}{*}{ Obs. } & \multirow[b]{2}{*}{ Mean } & \multirow[b]{2}{*}{ Median } & \multicolumn{3}{|c|}{ All } & & & & \multirow{2}{*}{$\begin{array}{l}\text { Sponsored VS } \\
\text { All Non- } \\
\text { sponsored } \\
\end{array}$} & \multirow{2}{*}{$\begin{array}{c}\text { Spons. VS } \\
\text { Highest Lev- } \\
\text { Quart. Non-spon. }\end{array}$} \\
\hline & & & & & Obs. & Mean & Median & & & Median & & \\
\hline \multicolumn{13}{|c|}{ Panel A: Covenant frequency in the cross section } \\
\hline No. of financial covenants & \# & 129 & 3.64 & 4.00 & 1,423 & 2.81 & 3.00 & 355 & 2.78 & 3.00 & $0.00^{* * *}$ & $0.00^{* * *}$ \\
\hline D/EBITDA & $\%$ & 129 & $97 \%$ & $100 \%$ & 1,423 & $71 \%$ & $100 \%$ & 355 & $59 \%$ & $100 \%$ & $0.00^{* * *}$ & $0.00^{* * *}$ \\
\hline EBITDA/I & $\%$ & 129 & $80 \%$ & $100 \%$ & 1,423 & $46 \%$ & $0 \%$ & 355 & $50 \%$ & $0 \%$ & $0.00^{* * *}$ & $0.00 * * *$ \\
\hline Cash flow & $\%$ & 129 & $97 \%$ & $100 \%$ & 1,423 & $56 \%$ & $100 \%$ & 355 & $52 \%$ & $100 \%$ & $0.00^{* * *}$ & $0.00 * * *$ \\
\hline Capex & $\%$ & 129 & $74 \%$ & $100 \%$ & 1,423 & $40 \%$ & $0 \%$ & 355 & $49 \%$ & $0 \%$ & $0.00^{* * *}$ & $0.00 * * *$ \\
\hline $\mathrm{D} / \mathrm{E}$ & $\%$ & 129 & $0 \%$ & $0 \%$ & 1,423 & $15 \%$ & $0 \%$ & 355 & $17 \%$ & $0 \%$ & $0.00^{* * *}$ & $0.00 * * *$ \\
\hline Current Ratio & $\%$ & 129 & $0 \%$ & $0 \%$ & 1,423 & $5 \%$ & $0 \%$ & 355 & $3 \%$ & $0 \%$ & $0.00^{* * *}$ & $0.07^{*}$ \\
\hline Net Worth & $\%$ & 129 & $0 \%$ & $0 \%$ & 1,423 & $29 \%$ & $0 \%$ & 355 & $30 \%$ & $0 \%$ & $0.00 * * *$ & $0.00 * * *$ \\
\hline \multicolumn{13}{|c|}{ Panel B: Covenant frequency over time } \\
\hline \multicolumn{13}{|l|}{ Pre credit boom (00-03) } \\
\hline No. of financial covenants & \# & 16 & 3.94 & 4.00 & 595 & 3.09 & 3.00 & 199 & 2.97 & 3.00 & $0.00 * * *$ & $0.00 * * *$ \\
\hline D/EBITDA & $\%$ & 16 & $88 \%$ & $100 \%$ & 595 & $65 \%$ & $100 \%$ & 199 & $52 \%$ & $100 \%$ & $0.06 *$ & $0.01 * *$ \\
\hline EBITDA/I & $\%$ & 16 & $100 \%$ & $100 \%$ & 595 & $46 \%$ & $0 \%$ & 199 & $51 \%$ & $100 \%$ & $0.00^{* * *}$ & $0.00^{* * *}$ \\
\hline Cash flow & $\%$ & 16 & $100 \%$ & $100 \%$ & 595 & $64 \%$ & $100 \%$ & 199 & $58 \%$ & $100 \%$ & $0.00^{* * *}$ & $0.00^{* * *}$ \\
\hline Capex & $\%$ & 16 & $69 \%$ & $100 \%$ & 595 & $45 \%$ & $0 \%$ & 199 & $50 \%$ & $100 \%$ & $0.06^{*}$ & 0.16 \\
\hline $\mathrm{D} / \mathrm{E}$ & $\%$ & 16 & $0 \%$ & $0 \%$ & 595 & $22 \%$ & $0 \%$ & 199 & $22 \%$ & $0 \%$ & $0.04 * *$ & $0.04^{* *}$ \\
\hline Current Ratio & $\%$ & 16 & $0 \%$ & $0 \%$ & 595 & $8 \%$ & $0 \%$ & 199 & $3 \%$ & $0 \%$ & 0.24 & 0.52 \\
\hline Net Worth & $\%$ & 16 & $13 \%$ & $0 \%$ & 595 & $42 \%$ & $0 \%$ & 199 & $41 \%$ & $0 \%$ & $0.02 * *$ & $0.03^{* *}$ \\
\hline
\end{tabular}

Table 12: $\quad$ Covenants in sponsored and non-sponsored loans (term loans) I/II

Source: $\quad$ LBO dataset and Dealscan 


\begin{tabular}{|c|c|c|c|c|c|c|c|c|c|c|c|c|}
\hline \multirow[t]{3}{*}{ Variables } & \multirow[t]{3}{*}{ Unit } & \multicolumn{3}{|c|}{ Sponsored loans } & \multicolumn{3}{|c|}{ Non-sponsored loans } & \multirow{2}{*}{\multicolumn{3}{|c|}{$\begin{array}{c}\text { Non-sponsored loans } \\
\text { Highest Leverage Quartile }\end{array}$}} & \multicolumn{2}{|c|}{$\begin{array}{c}\text { Diff. test } \\
\text { (Wilcoxon) }\end{array}$} \\
\hline & & \multirow[b]{2}{*}{ Obs. } & \multirow[b]{2}{*}{ Mean } & \multirow[b]{2}{*}{ Median } & \multicolumn{3}{|c|}{ All } & & & & Sponsored VS & Spons. VS \\
\hline & & & & & Obs. & Mean & Median & Obs. & Mean & Median & $\begin{array}{l}\text { All Non- } \\
\text { sponsored }\end{array}$ & $\begin{array}{c}\text { Highest Lev- } \\
\text { Quart. Non-spon. }\end{array}$ \\
\hline \multicolumn{13}{|l|}{ Credit boom (04-07) } \\
\hline No. of financial covenants & \# & 106 & 3.58 & 4.00 & 748 & 2.62 & 3.00 & 132 & 2.54 & 3.00 & $0.00^{* * *}$ & $0.00^{* * *}$ \\
\hline D/EBITDA & $\%$ & 106 & $96 \%$ & $100 \%$ & 748 & $77 \%$ & $100 \%$ & 132 & $67 \%$ & $100 \%$ & $0.00^{* * *}$ & $0.00^{* * *}$ \\
\hline EBITDA/I & $\%$ & 106 & $75 \%$ & $100 \%$ & 748 & $46 \%$ & $0 \%$ & 132 & $49 \%$ & $0 \%$ & $0.00^{* * *}$ & $0.00^{* * *}$ \\
\hline Cash flow & $\%$ & 106 & $96 \%$ & $100 \%$ & 748 & $50 \%$ & $100 \%$ & 132 & $44 \%$ & $0 \%$ & $0.00^{* * *}$ & $0.00^{* * *}$ \\
\hline Capex & $\%$ & 106 & $74 \%$ & $100 \%$ & 748 & $39 \%$ & $0 \%$ & 132 & $49 \%$ & $0 \%$ & $0.00^{* * *}$ & $0.00^{* * *}$ \\
\hline $\mathrm{D} / \mathrm{E}$ & $\%$ & 106 & $0 \%$ & $0 \%$ & 748 & $10 \%$ & $0 \%$ & 132 & $8 \%$ & $0 \%$ & $0.00^{* * *}$ & $0.00^{* * *}$ \\
\hline Current Ratio & $\%$ & 106 & $0 \%$ & $0 \%$ & 748 & $4 \%$ & $0 \%$ & 132 & $2 \%$ & $0 \%$ & $0.05^{* *}$ & 0.20 \\
\hline Net Worth & $\%$ & 106 & $2 \%$ & $0 \%$ & 748 & $19 \%$ & $0 \%$ & 132 & $15 \%$ & $0 \%$ & $0.00^{* * *}$ & $0.00^{* * *}$ \\
\hline \multicolumn{13}{|l|}{ Post credit boom (08) } \\
\hline No. of financial covenants & \# & 7 & 4.00 & 4.00 & 80 & 2.36 & 2.00 & 24 & 2.58 & 3.00 & $0.00^{* * *}$ & $0.00^{* * *}$ \\
\hline D/EBITDA & $\%$ & 7 & $100 \%$ & $100 \%$ & 80 & $73 \%$ & $100 \%$ & 24 & $67 \%$ & $100 \%$ & 0.11 & $0.08^{*}$ \\
\hline EBITDA/I & $\%$ & 7 & $100 \%$ & $100 \%$ & 80 & $44 \%$ & $0 \%$ & 24 & $42 \%$ & $0 \%$ & $0.00^{* * *}$ & $0.00^{* * *}$ \\
\hline Cash flow & $\%$ & 7 & $100 \%$ & $100 \%$ & 80 & $43 \%$ & $0 \%$ & 24 & $46 \%$ & $0 \%$ & $0.00^{* * *}$ & $0.01 * *$ \\
\hline Capex & $\%$ & 7 & $100 \%$ & $100 \%$ & 80 & $21 \%$ & $0 \%$ & 24 & $33 \%$ & $0 \%$ & $0.00^{* * *}$ & $0.00^{* * *}$ \\
\hline $\mathrm{D} / \mathrm{E}$ & $\%$ & 7 & $0 \%$ & $0 \%$ & 80 & $18 \%$ & $0 \%$ & 24 & $25 \%$ & $0 \%$ & 0.25 & 0.15 \\
\hline Current Ratio & $\%$ & 7 & $0 \%$ & $0 \%$ & 80 & $5 \%$ & $0 \%$ & 24 & $8 \%$ & $0 \%$ & 0.55 & 0.44 \\
\hline Net Worth & $\%$ & 7 & $0 \%$ & $0 \%$ & 80 & $23 \%$ & $0 \%$ & 24 & $21 \%$ & $0 \%$ & 0.16 & 0.19 \\
\hline \multicolumn{13}{|c|}{ Panel C: Financial risk of borrowers } \\
\hline D/EV & \# & 129 & 0.65 & 0.66 & 1,423 & 0.37 & 0.33 & 355 & 0.68 & 0.65 & $0.00^{* * *}$ & 0.30 \\
\hline D/EBITDA & \# & 129 & 5.48 & 5.35 & 1,295 & 3.47 & 2.87 & 305 & 5.64 & 5.08 & $0.00^{* * *}$ & 0.35 \\
\hline
\end{tabular}

Table 13: $\quad$ Covenants in sponsored and non-sponsored loans (term loans) II/II Source: $\quad$ LBO dataset and Dealscan 
Besides the use of individual financial covenants, it is interesting to note how they are used in interaction. Table 14 documents the probabilities of encountering a specific covenant conditional on the existence of another covenant. Panel A focuses on the sponsored loans and Panel B reports the non-sponsored benchmark.

\begin{tabular}{|c|c|c|c|c|c|c|c|}
\hline \multicolumn{8}{|c|}{ Panel A: Sponsored loans } \\
\hline \multicolumn{8}{|c|}{ Probability of a covenant in row $i$, conditional of a covenant in column $j$} \\
\hline Covenant & 1 & 2 & 3 & 4 & 5 & 6 & 7 \\
\hline 1 D/EBITDA & & 0.81 & 0.98 & 0.77 & 0.00 & 0.00 & 0.00 \\
\hline 2 EBITDA/I & 0.97 & & 0.97 & 0.88 & 0.00 & 0.00 & 0.00 \\
\hline 3 Cash flow & 0.97 & 0.80 & & 0.75 & 0.00 & 0.00 & 0.00 \\
\hline 4 Capex & 0.98 & 0.94 & 0.97 & & 0.00 & 0.00 & 0.00 \\
\hline 5 D/Equity & 0.00 & 0.00 & 0.00 & 0.00 & & 0.00 & 0.00 \\
\hline 6 Current ratio & 0.00 & 0.00 & 0.00 & 0.00 & 0.00 & & 0.00 \\
\hline 7 Net worth & 0.00 & 0.00 & 0.00 & 0.00 & 0.00 & 0.00 & \\
\hline \multicolumn{8}{|c|}{ Panel B: Non-sponsored loans } \\
\hline \multicolumn{8}{|c|}{ Probability of a covenant in row $i$, conditional of a covenant in column $j$} \\
\hline Covenant & 1 & 2 & 3 & 4 & 5 & 6 & 7 \\
\hline 1 D/EBITDA & & 0.51 & 0.57 & 0.45 & 0.06 & 0.05 & 0.22 \\
\hline 2 EBITDA/I & 0.69 & & 0.32 & 0.36 & 0.15 & 0.10 & 0.28 \\
\hline 3 Cash flow & 0.64 & 0.27 & & 0.45 & 0.16 & 0.06 & 0.34 \\
\hline 4 Capex & 0.67 & 0.40 & 0.61 & & 0.07 & 0.04 & 0.26 \\
\hline 5 D/Equity & 0.21 & 0.38 & 0.51 & 0.17 & & 0.15 & 0.53 \\
\hline 6 Current ratio & 0.30 & 0.46 & 0.33 & 0.17 & 0.26 & & 0.58 \\
\hline 7 Net worth & 0.34 & 0.31 & 0.47 & 0.27 & 0.23 & 0.15 & \\
\hline
\end{tabular}

Table 14: Conditional probabilities of covenant inclusion Source: $\quad$ LBO dataset and Dealscan

As expected, the conditional probabilities in the sponsored sample (Panel A) are high between all four premier covenants (D/EBITDA, EBITDA/I, Cash Flow Coverage and Capex covenants) while they are zero if any of the three remaining covenants $(D / E$, Current Ratio and Net Worth) is considered. In the non-sponsored sample (Panel B), the conditional probabilities are more evenly distributed between all seven covenants. This pattern indicates that there is less variation in the set of covenant combinations 
for the sponsored than for the non-sponsored sample. Table 15 examines this notion in greater detail by investigating the frequencies of the premier covenant combinations for both samples: The most frequent combination in sponsored loans, which contains D/EBITDA, EBITDA/I, CashFlowCoverage and Capex covenants, is found in $68.2 \%$ of the sponsored sample. By contrast, the most frequent combination in non-sponsored loans, which comprehends D/EBITDA and EBITDA/I covenants, is encountered in only $13.2 \%$ of the sponsored sample. ${ }^{322}$ Hence, the covenant structure in terms of covenant combinations is more standardized in sponsored than in non-sponsored loans.

\begin{tabular}{|c|c|c|c|}
\hline & Unit & Sponsored loans & Non-sponsored loans \\
\hline \multicolumn{4}{|l|}{ Covenant combinations } \\
\hline Frequency of top 3 covenant combinations & $\%$ & $89.9 \%$ & $31.8 \%$ \\
\hline Frequency of premier covenant combination & $\%$ & $68.2 \%$ & $13.2 \%$ \\
\hline \multicolumn{4}{|l|}{ Structure of premier covenant combination } \\
\hline$D / E B I T D A$ & & yes & yes \\
\hline EBITDA/I & & yes & yes \\
\hline Cash flow & & yes & no \\
\hline Capex & & yes & no \\
\hline$D / E$ & & no & no \\
\hline Current Ratio & & no & no \\
\hline Net Worth & & no & no \\
\hline
\end{tabular}

Table 15: Covenant combinations in sponsored and non-sponsored loans Source: $\quad$ LBO dataset and Dealscan

The aforementioned statistics for the individual covenants from Table 12 translate into the observation that sponsored loans restrict more financial ratios than non-sponsored loans. On average, sponsored loan deals include 3.6 covenants, whereas their nonsponsored counterparts comprehend 2.8 covenants, the difference being statistically significant at the $1 \%$ level. Having documented this sharp difference, the natural question which arises is why do sponsored loans include more financial covenants?

\footnotetext{
${ }^{322}$ Similarly, if the analysis is extended to the top three covenant combinations, the author observes that one of these premier combinations is present in $89.9 \%$ of the sponsored sample while the author finds that one of these combinations is inherent in only $31.8 \%$ of the non-sponsored sample.
} 
One obvious explanation could be the increased financial risk argument: the underlying financial risk of the loans might be much higher for sponsored than for nonsponsored loans leading to a more restrictive covenant package. This explanation is tested by comparing D/EV and D/EBITDA levels of sponsored versus non-sponsored loans. Hence, the author collects financials for non-sponsored loan sample from Compustat for the financial year following the loan issuance. Indeed, looking at D/EBITDA and D/EV in Panel C of Table 12 reveals that sponsored loans have significantly higher underlying leverage levels than non-sponsored borrowers. There are two interesting questions: are there non-sponsored loans with comparable leverage levels and, if there are comparable loans, how does their covenant structure look like as compared to sponsored but also to lower leverage sponsored loans.

As a simple test the author sorts the benchmark sample according to D/EV (or D/EBITDA which yields identical results) and looks at the characteristics of the quartile of loans with the highest financial risk. It shows that the highest leverage quartile of non-sponsored loans exhibits comparable financial risk $(\mathrm{D} / \mathrm{EV}=68.4 \%$ and D/EBITDA =5.64) to the sponsored loan sample. ${ }^{323}$ Interestingly, when looking at the covenant structure, the highest leverage quartile shows a similar covenant structure to the overall non-sponsored loan sample, both having less financial covenants than sponsored loans. This seems particularly puzzling as the information asymmetry costs argument would suggest that sponsored loans would receive a looser covenant setting when financial risk is similar to non-sponsored loans.

The findings may be inaccurate if the benchmark is not appropriate. In order to investigate this possibility, the author conducts the same procedure with loans used for acquisition purposes, builds industry-year-leverage matches for the term loan sample, and builds industry-year-leverage matches for the acquisition loan sample. With respect to the financial risk of the borrowers, the author matches the sponsored loans to non-sponsored loans according to year, industry and leverage. In particular, all compa-

\footnotetext{
${ }^{323}$ The author is confident that the non-sponsored borrowers are not in distress as syndicated loans are typically not provided to distressed companies.
} 
nies qualify that originated a syndicated loan in the same year as the LBO target company.

Then, those companies are retained which operate in the same two-digit SIC industry. In case there are fewer than 5 potential matched firms, the one-digit SIC code is used. The peer firm is then the firm whose financial risk measure (D/EBITDA) is closest to that of the LBO target company. Having matched the loans, the results still remain virtually the same across all samples (see for the matched term loan sample Table 16). This strengthens the notion that the results are not systematically biased by the benchmarking choice.

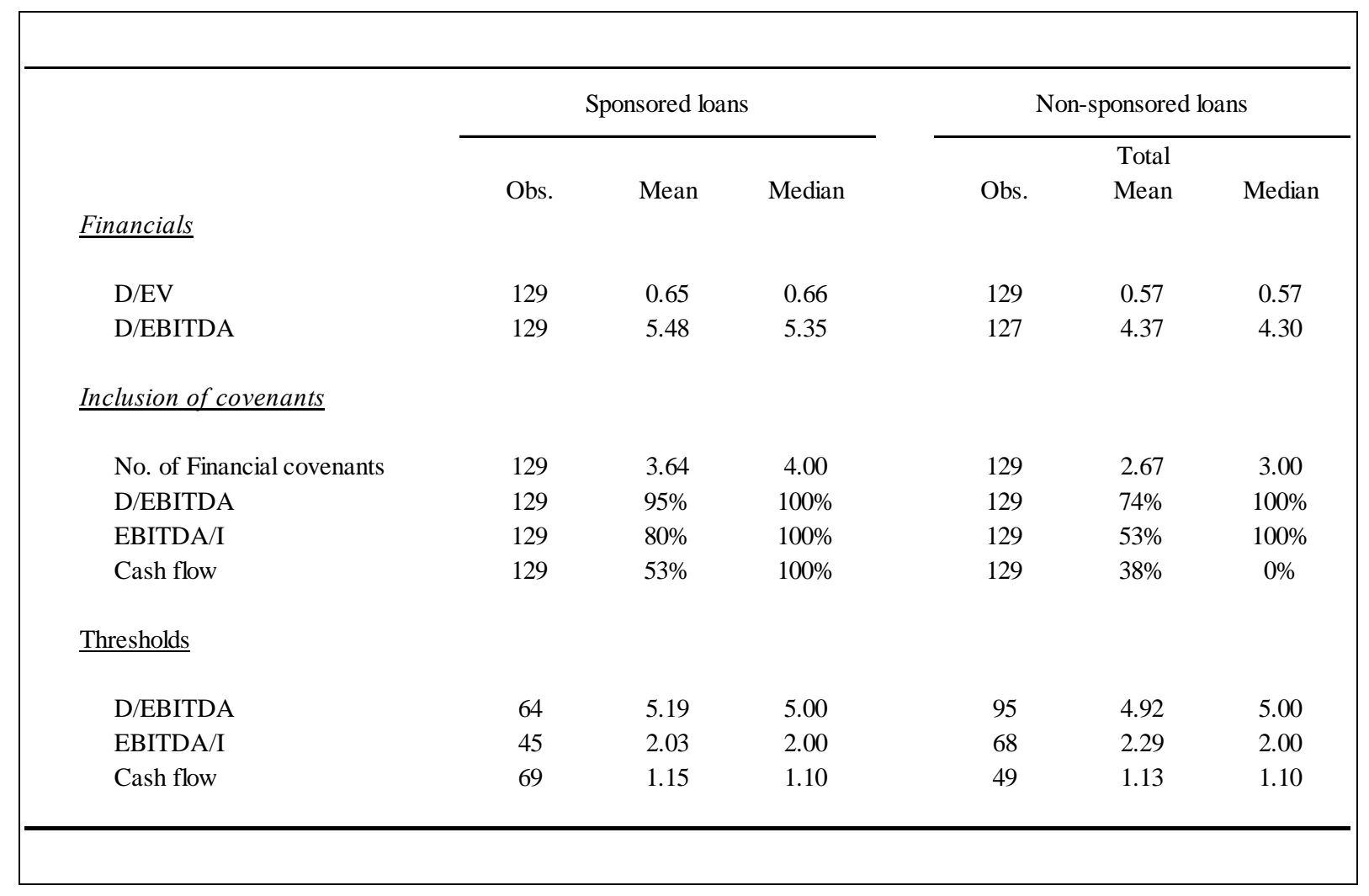

Table 16: Covenants in sponsored and non-sponsored loans (matched term loans) Source: $\quad$ LBO dataset and Dealscan

Another intuitive explanation for the findings is that sponsored loans contain more covenants but they may be less restrictive. The author tries to shed light on this issue by investigating the covenant thresholds, the only proxy of covenant restrictiveness available for the benchmark sample. 


\subsubsection{Financial Covenant Thresholds}

The previous section demonstrated that sponsored loans contain more financial covenants than non-sponsored loans, irrespective of the financial risk of the borrower. Therefore, this section compares the thresholds of financial covenants in sponsored and non-sponsored loans. Table 17 and Table 18 report the results. Non-sponsored loans are divided into quartiles according to their financial risk (D/EV) ${ }^{324}$ The following paragraph concentrates on the comparison of covenant thresholds between the sponsored loans and the fourth quartile of non-sponsored loans with the highest financial risk (in the following called fourth quartile).

What seems puzzling at first is that the D/EBITDA financial risk variable is larger than the D/EBITDA covenant thresholds, both for sponsored and non sponsored loans. This would indicate that the average loan is in covenant breach. However, covenants are typically tested for the first time twelve months after loan inception. During this period the borrower is expected to reduce the outstanding debt and typically increase EBITDA, leading to an expected financial ratio which is considerably below the covenant threshold.

In terms of results, the data shows a mixed picture across the three main covenants. The threshold of the D/EBITDA covenant is almost identical in sponsored (5.02) and fourth quartile (5.30) loans, the difference being statistically insignificant (p-value of 0.11). The restrictiveness of thresholds for the EBITDA/I and CashFlowCoverage covenant is different between sponsored and non-sponsored loans (both with a p-value $<0.01$ ), however, in opposite directions in terms of restrictiveness. On the one hand, the mean sponsored loan has a 0.75 (26.9\%) higher EBITDA/I threshold, i.e. is more restrictive. On the other hand, the mean sponsored loan has a 0.25 (24.5\%) lower CashFlowCoverage threshold compared to the mean non-sponsored loan, i.e. is less restrictive. Again, the author investigates whether these results may be subject to a selection bias of the benchmark sample. The author calculates the thresholds for all alternative benchmark samples but the finding remains the same.

\footnotetext{
${ }^{324}$ Sorting the sample according to D/EBITDA leads to virtually identical results.
} 


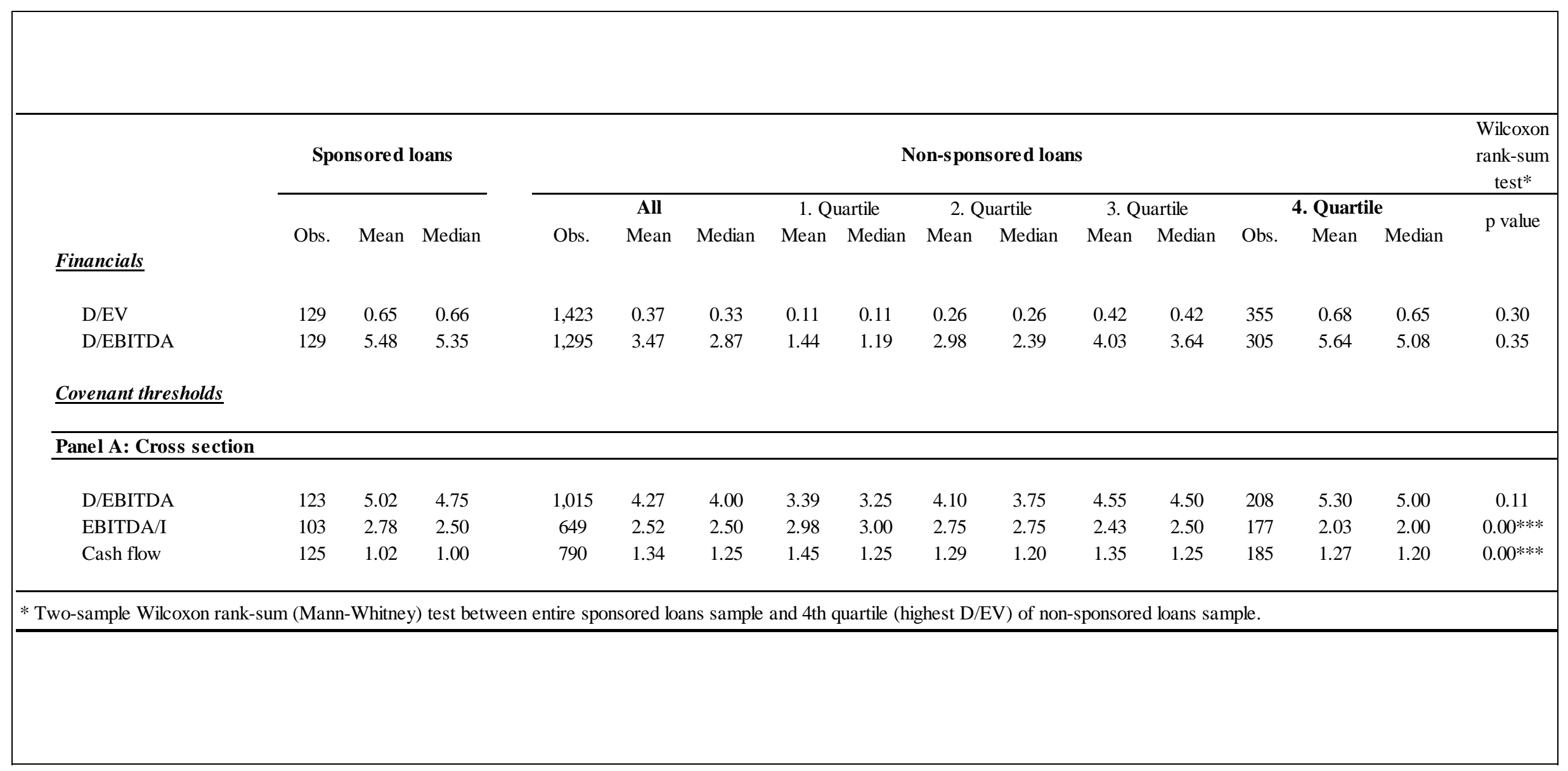

Table 17: $\quad$ Covenant thresholds of sponsored and non-sponsored loans I/II Source: $\quad$ LBO dataset and Dealscan 


\begin{tabular}{|c|c|c|c|c|c|c|c|c|c|c|c|c|c|c|c|c|}
\hline & \multicolumn{3}{|c|}{ Sponsored loans } & \multicolumn{12}{|c|}{ Non-sponsored loans } & \multirow{3}{*}{$\begin{array}{c}\begin{array}{c}\text { Wilcoxon } \\
\text { rank-sum } \\
\text { test* }\end{array} \\
\text { p value }\end{array}$} \\
\hline & \multirow[b]{2}{*}{ Obs. } & \multirow[b]{2}{*}{ Mean } & \multirow[b]{2}{*}{ Median } & \multicolumn{3}{|c|}{ All } & \multicolumn{2}{|c|}{ 1. Quartile } & \multicolumn{2}{|c|}{ 2. Quartile } & \multicolumn{2}{|c|}{ 3. Quartile } & \multicolumn{3}{|c|}{ 4. Quartile } & \\
\hline & & & & Obs. & Mean & Median & Mean & Median & Mean & Median & Mean & Median & Obs. & Mean & Median & \\
\hline \multicolumn{17}{|c|}{ Panel B: Time series } \\
\hline \multicolumn{17}{|c|}{ Pre credit boom (00-03) } \\
\hline D/EBITDA & 14 & 4.04 & 3.95 & 384 & 4.22 & 4.00 & 3.03 & 3.00 & 4.18 & 3.50 & 4.31 & 4.05 & 104 & 5.09 & 5.00 & $0.01^{* *}$ \\
\hline EBITDA/I & 16 & 3.58 & 3.23 & 271 & 2.42 & 2.25 & 2.98 & 3.00 & 2.78 & 3.00 & 2.37 & 2.45 & 102 & 2.01 & 1.90 & $0.00^{* * *}$ \\
\hline Cash flow & 16 & 1.05 & 1.00 & 381 & 1.34 & 1.25 & 1.44 & 1.35 & 1.32 & 1.25 & 1.36 & 1.25 & 116 & 1.27 & 1.15 & $0.00^{* * *}$ \\
\hline \multicolumn{17}{|c|}{ Credit boom (04-07) } \\
\hline D/EBITDA & 102 & 5.16 & 4.90 & 573 & 4.36 & 4.00 & 3.55 & 3.25 & 4.08 & 0.00 & 4.80 & 4.60 & 88 & 5.74 & 5.50 & $0.02^{* *}$ \\
\hline EBITDA/I & 80 & 2.65 & 2.33 & 343 & 2.57 & 2.50 & 2.98 & 3.00 & 2.72 & 2.75 & 2.44 & 2.50 & 65 & 1.99 & 2.00 & $0.00^{* * *}$ \\
\hline Cash flow & 102 & 1.02 & 1.00 & 375 & 1.33 & 1.25 & 1.46 & 1.25 & 1.27 & 1.20 & 1.30 & 1.25 & 58 & 1.23 & 1.15 & $0.00^{* * *}$ \\
\hline \multicolumn{17}{|c|}{ Post credit boom (0 } \\
\hline D/EBITDA & 7 & 4.87 & 4.19 & 58 & 3.74 & 3.50 & 3.45 & 3.38 & 3.68 & 0.00 & 3.44 & 3.50 & 16 & 4.29 & 4.00 & 0.42 \\
\hline EBITDA/I & 7 & 2.50 & 2.50 & 35 & 2.73 & 3.00 & 2.93 & 3.00 & 2.77 & 3.00 & 2.52 & 2.75 & 10 & 2.52 & 2.50 & 0.73 \\
\hline Cash flow & 7 & 1.00 & 1.00 & 34 & 1.51 & 1.30 & 1.59 & 1.35 & 1.34 & 1.25 & 1.74 & 1.25 & 11 & 1.40 & 1.50 & $0.00^{* * *}$ \\
\hline
\end{tabular}

Table 18: $\quad$ Covenant thresholds of sponsored and non-sponsored loans II/II

Source: $\quad$ LBO dataset and Dealscan 
This finding might have several different explanations. First, financial covenants might adhere to a certain economic logic, i.e. hierarchical order, where one would have to compare the most restrictive financial covenants between loans to infer any conclusions regarding the restrictiveness of the covenant package. A second explanation is merely technical. Assume that the D/EBITDA multiple is identical and all else being equal, loans sponsored by private equity sponsors benefit from lower interest cost. Lower interest cost increases the EBITDA/I ratio and therefore increases the EBITDA/I covenant threshold, holding headroom constant.

What seems another likely explanation is that thresholds as absolute values of financial ratios may not represent a direct measure of covenant restrictiveness as indicated by IVASHINA/KOVNER (2010). Indeed, the data supports this notion: in all four benchmark quartiles, the thresholds (D/EBITDA, EBITDA/I and CashFlowCoverage) vary monotonically across the quartile subsamples (Table 17). For example, the D/EBITDA threshold grows monotonically with increasing leverage levels (from 3.4 in the first quartile to 5.3 in the fourth quartile). These results suggest that thresholds are directly driven by the underlying financial risk of the borrower and do not represent a direct measure of covenant restrictiveness.

Hence, the author is not able to formally test the conjecture that sponsored loans may include more but less restrictive covenants than non-sponsored loans. However, the rich nature of the proprietary LBO dataset allows an in-depth examination of the financial covenant restrictiveness for sponsored loans. The author is able to precisely determine the magnitude of covenant restrictiveness and thereby to test the competing arguments of the impact of information asymmetry costs and financial risk on covenant restrictiveness.

\subsection{Descriptive Statistics}

\subsubsection{Covenant Restrictiveness}

To test the determinants of financial covenant restrictiveness in an empirical setting, a variable that best describes the latent construct of covenant restrictiveness has to be developed and described for the LBO dataset. As seen in section 4.3.3 the headroom is 
most likely to be strongly correlated to covenant restrictiveness. However, as reported in the section above, sponsored loans typically contain three financial covenants. The question remains, which headroom is likely to be the most restrictive and consequently the one that is the primary negotiated item in covenant determination. This section presents the thresholds and headrooms of the three main financial covenants in LBOs, namely D/EBITDA, EBITDA/I and CashFlowCoverage. Table 19 and Table 20 documents the development of thresholds and headrooms over the first three years after the transaction (i.e. $t=1$ to $t=3$ ) for both the whole sample and subsamples of loans negotiated in different years.

Table 19 shows that D/EBITDA covenant thresholds typically decrease from $t=1$ to $t=3$, being mechanically driven by the reduction of debt and the expected increase of EBITDA (assuming constant headroom). D/EBITDA covenant thresholds increased from pre-2004 to the presumably overheated period from 2004 to 2007. This development was mainly driven by the increased leverage levels at loan inception. Intuitively, after the burst of the credit bubble, leveraged covenant thresholds decreased in 2008. In contrast to the D/EBITDA threshold, the EBITDA/I threshold increases over the planning horizon ( $\mathrm{t}=1$ to $\mathrm{t}=3$ ). This observation is also mechanical, since interest payments stay fairly stable - as only the relatively lower spread Term A loan is redeemed - and EBITDA is mostly forecasted to grow (again assuming a constant headroom). During the credit boom, the EBITDA/I thresholds were lower than pre 2004 and 2008 levels.

More striking is the setting of the CashFlowCoverage covenant threshold. First, it only experiences very little variation from $\mathrm{t}=1$ to $\mathrm{t}=3$, i.e. it is mostly set to 1.0. Second, in earlier years some cash flow covenant thresholds were greater than 1 , but during the boom times the threshold was standardized to 1 . This seems puzzling, as financial covenants are presumably utilized to serve as a signal for the state of the firm so that lenders can intervene early to limit wealth reduction. However, if a cash flow covenant of 1 is violated, the firm cannot satisfy its debt obligations from its ongoing cash flows. Only if the existing cash level is sufficient to cover outstanding payments or if equity injections by sponsors are made, the firm can avoid payment default. However, 
banks should not expect borrowers to have any cash on hand or private equity sponsors to inject additional equity. ${ }^{325}$ Thus, assuming none of the two aforementioned possibilities, this setting would not give the lender any time to intervene before they are confronted with default payments. Consequently, it seems that lenders may apply some specific logic to their financial covenant setting where the cash flow cover covenant is used as a signal of last resort.

Table 20 presents headrooms for the sample. In contrast to thresholds, headrooms are easier to interpret as they provide a direct view of the restrictiveness of financial covenants. There is no evidence that financial covenants are stricter in the early years of the planning horizon and are relaxed over time from $t=1$ to $t=3$. While all three financial covenants adhere to this systematic, the D/EBITDA covenant shows a faster relief (delta of medians $\mathrm{t}=1$ versus $\mathrm{t}=3$ equals $(28.4-22.6)=5.8$ percentage points $)$ than the EBITDA/I (delta of medians $t=1$ versus $t=3$ equals 2.2 percentage points) and the CashFlowCoverage covenant (delta of medians $t=1$ versus $t=3$ equals 3.4 percentage points). This observation lends strong evidence to the financial risk argument since the forecasted headrooms present a quasi ceteris paribus setting: only the financial risk changes from $\mathrm{t}=1$ to $\mathrm{t}=3$ but everything else remains constant.

The D/EBITDA and EBITDA/I headroom at $\mathrm{t}=1$ were set less restrictive during the credit boom period from 2004 to 2007 in comparison to pre- and post-crunch time. Interestingly, over the planning horizon the variance of leverage and interest cover headrooms become larger, showing the non-standardized character of the covenant setting.

\footnotetext{
${ }^{325}$ Indeed, there have been only few equity injections by private equity sponsors in the 2008/2009 period.
} 


\begin{tabular}{|c|c|c|c|c|c|c|c|c|c|c|}
\hline \multirow[t]{2}{*}{ Deal year } & \multirow[t]{2}{*}{ Statistics } & \multicolumn{3}{|c|}{ D/EBITDA } & \multicolumn{3}{|c|}{ EBITDA/I } & \multicolumn{3}{|c|}{ CashFlowCoverage } \\
\hline & & $\mathbf{t}=\mathbf{1}$ & $t=2$ & $t=3$ & $\mathbf{t}=\mathbf{1}$ & $t=2$ & $t=3$ & $\mathbf{t}=1$ & $t=2$ & $t=3$ \\
\hline \multirow[t]{2}{*}{2000} & Median & 3.40 & 2.80 & 2.40 & 2.20 & 2.40 & 2.60 & 1.05 & 1.05 & 1.10 \\
\hline & $\mathrm{n}$ & 1 & 1 & 1 & 1 & 1 & 1 & 1 & 1 & 1 \\
\hline \multirow[t]{2}{*}{2001} & Median & 4.83 & 4.30 & 3.68 & 2.68 & 3.00 & 3.30 & 1.00 & 1.00 & 1.00 \\
\hline & $\mathrm{n}$ & 2 & 2 & 2 & 2 & 2 & 2 & 1 & 1 & 1 \\
\hline \multirow[t]{2}{*}{2002} & Median & 4.05 & 3.40 & 2.85 & 3.03 & 3.50 & 4.05 & 1.00 & 1.00 & 1.03 \\
\hline & $\mathrm{n}$ & 6 & 6 & 6 & 6 & 6 & 6 & 6 & 6 & 6 \\
\hline \multirow[t]{2}{*}{2003} & Median & 3.85 & 3.20 & 3.00 & 4.00 & 4.00 & 4.00 & 1.08 & 1.10 & 1.15 \\
\hline & $\mathrm{n}$ & 5 & 5 & 5 & 7 & 7 & 7 & 6 & 6 & 6 \\
\hline \multirow[t]{2}{*}{2004} & Median & 5.30 & 4.55 & 4.10 & 2.50 & 2.90 & 3.25 & 1.00 & 1.00 & 1.00 \\
\hline & $\mathrm{n}$ & 20 & 20 & 20 & 19 & 19 & 19 & 18 & 18 & 18 \\
\hline \multirow[t]{2}{*}{2005} & Median & 4.60 & 4.25 & 3.82 & 2.58 & 2.68 & 2.97 & 1.00 & 1.00 & 1.00 \\
\hline & $\mathrm{n}$ & 25 & 25 & 25 & 20 & 20 & 20 & 26 & 26 & 26 \\
\hline \multirow[t]{2}{*}{2006} & Median & 4.50 & 3.90 & 3.30 & 2.68 & 2.85 & 3.15 & 1.00 & 1.00 & 1.00 \\
\hline & $\mathrm{n}$ & 31 & 31 & 31 & 20 & 20 & 20 & 31 & 31 & 31 \\
\hline \multirow[t]{2}{*}{2007} & Median & 5.30 & 4.40 & 4.20 & 2.05 & 2.26 & 2.44 & 1.00 & 1.00 & 1.00 \\
\hline & $\mathrm{n}$ & 28 & 28 & 27 & 22 & 22 & 22 & 29 & 29 & 29 \\
\hline \multirow[t]{2}{*}{2008} & Median & 4.15 & 3.38 & 3.00 & 2.50 & 2.70 & 2.90 & 1.00 & 1.00 & 1.00 \\
\hline & $\mathrm{n}$ & 8 & 8 & 8 & 7 & 7 & 7 & 8 & 8 & 8 \\
\hline \multirow[t]{3}{*}{ Total } & Median & 4.60 & 4.10 & 3.50 & 2.50 & 2.70 & 2.97 & 1.00 & 1.00 & 1.00 \\
\hline & Std. & 1.83 & 1.73 & 1.56 & 1.13 & 1.29 & 1.34 & 0.05 & 0.06 & 0.06 \\
\hline & $\mathbf{n}$ & 126 & 126 & 125 & 104 & 104 & 104 & 126 & 126 & 126 \\
\hline \multicolumn{11}{|l|}{ Time trends: } \\
\hline $\begin{array}{l}\text { Pre credit boom (00-03) } \\
\text { VS. credit boom (04-07) }\end{array}$ & & $(+)^{* *}$ & $(+)^{* *}$ & $(+)^{* *}$ & $(-)^{* * *}$ & $(-)^{* * *}$ & $(-)^{* * *}$ & $(-)^{* * *}$ & $(-)^{* *}$ & $(-)^{* * *}$ \\
\hline $\begin{array}{l}\text { Credit boom (04-07) VS. } \\
\text { post credit boom (08) }\end{array}$ & & $(-)$ & $(-)$ & $(-)$ & $(+)$ & $(+)$ & $(+)$ & $(-)$ & $(-)$ & $(-)$ \\
\hline
\end{tabular}

Table 19: Covenant thresholds over time Source: LBO dataset 


\begin{tabular}{|c|c|c|c|c|c|c|c|c|c|c|}
\hline \multirow[t]{2}{*}{ Deal year } & \multirow[t]{2}{*}{ Statistics } & \multicolumn{3}{|c|}{ D/EBITDA } & \multicolumn{3}{|c|}{ EBITDA/I } & \multicolumn{3}{|c|}{ CashFlowCoverage } \\
\hline & & $t=1$ & $t=2$ & $t=3$ & $t=1$ & $t=2$ & $t=3$ & $t=1$ & $t=2$ & $t=3$ \\
\hline 2000 & Median & 13.6 & 18.8 & 28.0 & 20.1 & 27.10 & 34.50 & 25.00 & 9.00 & 25.00 \\
\hline 2001 & Median & 20.2 & 22.5 & 19.2 & 22.0 & 21.10 & 26.55 & 51.00 & 34.00 & 26.00 \\
\hline 2002 & Median & 25.1 & 27.9 & 31.4 & 22.1 & 20.40 & 26.80 & 25.00 & 27.50 & 31.50 \\
\hline 2003 & Median & 19.8 & 22.7 & 38.2 & 24.3 & 38.31 & 54.67 & 23.63 & 27.06 & 26.62 \\
\hline 2004 & Median & 25.1 & 26.9 & 28.0 & 25.9 & 26.20 & 24.40 & 33.15 & 29.21 & 30.50 \\
\hline 2005 & Median & 20.9 & 25.0 & 26.9 & 20.3 & 20.85 & 21.25 & 28.73 & 29.00 & 32.77 \\
\hline 2006 & Median & 21.9 & 24.1 & 30.0 & 24.0 & 25.40 & 28.15 & 34.02 & 31.25 & 31.25 \\
\hline 2007 & Median & 26.3 & 28.5 & 30.1 & 25.8 & 26.06 & 27.31 & 27.89 & 34.00 & 33.48 \\
\hline 2008 & Median & 24.2 & 26.0 & 25.8 & 22.4 & 25.00 & 25.20 & 27.50 & 27.28 & 34.19 \\
\hline \multirow[t]{3}{*}{ Total } & Median & 23.3 & 25.9 & 29.3 & 24.0 & 25.00 & 26.00 & 28.73 & 29.92 & 32.12 \\
\hline & Std. & 8.35 & 11.37 & 14.44 & 10.76 & 10.62 & 12.42 & 15.83 & 11.66 & 12.48 \\
\hline & $\mathbf{n}$ & 126 & 126 & 125 & 104 & 104 & 104 & 126 & 126 & 126 \\
\hline $\begin{array}{l}\text { Time trends: } \\
\text { Pre credit boom (00-03) } \\
\text { VS. credit boom (04-07) }\end{array}$ & & $(+)$ & $(+)$ & $(-)$ & $(+)$ & $(-)$ & $(-)^{* *}$ & $(+)$ & $(+)$ & $(+)$ \\
\hline $\begin{array}{l}\text { Credit boom (04-07) VS. } \\
\text { post credit boom (08) }\end{array}$ & & $(-)$ & $(-)$ & $(-)$ & $(-)$ & $(-)$ & $(-)$ & $(-)$ & $(-)$ & $(+)$ \\
\hline
\end{tabular}

Table 20: $\quad$ Covenant headrooms over time Source: $\quad$ LBO dataset

The CashFlowCoverage headroom is difficult to interpret. As indicated by the threshold, which is standardized to 1 , the CashFlowCoverage headroom results from negotiated items of the financing structure. Therefore, the CashFlowCoverage covenant headroom is not directly subject to negotiation. However, the negotiated financing structure, especially interest and redemption schedules, as well as the agreed operating cash flow forecast determine the headroom. For example, if the sponsor and the lead 
arranger negotiated a CashFlowCoverage ratio of $1.3 \mathrm{in} \mathrm{t}=1$, this would imply a headroom of 23\% (-[(1/1.3)-1]*100), assuming a covenant threshold of 1 . Hence, since it directly measures the distance to payment default, the CashFlowCoverage covenant headroom seems to be a good indicator of the overall financial risk of the transaction as it is a direct outcome of the agreed financing case.

While the D/EBITDA as well as the EBITDA/I covenant headrooms are directly negotiated and the interpretation of restrictiveness is straight-forward, the headroom of the CashFlowCoverage can be interpreted in two ways: On the one hand, large headroom indicates a large distance to a violation of the covenant and would imply a loose covenant setting. On the other hand, large headroom of the CashFlowCoverage covenant could be the outcome of a conservative capital structure. Therefore, the CashFlowCoverage covenant headroom cannot be taken as a proxy for covenant restrictiveness, as it is a mechanic product incorporating both financial structure and financial covenant restrictiveness. ${ }^{326}$

It still remains unclear, which financial covenant is the most restrictive and best mirrors the restrictiveness of a covenant setting. Therefore, the following section tries to analyze whether financial covenants are designed in a hierarchical manner.

\subsubsection{Financial Covenant Pecking Order}

The data analysis process reveals a pattern that suggests that financial covenant headrooms are not designed independently of each other, i.e. headrooms of the covenants follow a specific logic. Already the observed covenant thresholds suggested that the lead arrangers implement a 'pecking order' in the design of financial covenants meaning that the utilized covenants are meant to be violated sequentially. In particular the CashFlowCoverage covenant threshold, which is mostly set to 1 , indicated that this type of covenant is not used as a signal to intervene but as a lever of last resort. This suggests that the D/EBITDA covenant and the EBITDA/I covenant are likely to be

\footnotetext{
${ }^{326}$ For example: a very reputed sponsor might receive low CashFlowCoverage headroom because he receives more leverage than comparable non-reputed sponsors. This is not a signal for the restrictiveness of the cash flow cover covenant.
} 
utilized to fulfill the early warning signaling function of shifting control rights from the owners to the lenders, who might then intervene to protect their loans. Another explanation might be that EBITDA is a smoothed proxy for cash flow, implying that cash flow is more volatile than EBITDA, which might lead to higher renegotiation costs for tight CashFlowCoverage covenants.

Table 21 shows that financial covenant headrooms are stricter in the early years of the planning horizon and relaxed over time. ${ }^{327}$ While all three financial covenants adhere to this systematic, the D/EBITDA covenant shows a faster relief (delta of medians $\mathrm{t}$ = 1 versus $t=3$ equals 5.8 percentage points) than the EBITDA/I (delta of medians $t=1$ versus $t=3$ equals 2.2 percentage points) and the CashFlowCoverage covenant (delta of medians $t=1$ versus $t=3$ equals 3.4 percentage points). Compared to the other two, the CashFlowCoverage incorporates scheduled repayments that typically increase over time, keeping the debt service relatively constant, while leverage levels decrease.

To test whether financial covenants are designed in a hierarchical manner and whether this structure changes over time, headroom levels of the financial covenants are compared over time using a Mann-Whitney mean comparison test (t-values are reported on the right hand side in Table 21). The analysis shows that the leverage headroom in the first year after the transaction is significantly smaller than the headrooms of the EBITDA/I and CashFlowCoverage covenant. This result implies that in the first year after the transaction a buyout firm would first breach the leverage covenant then the EBITDA/I and lastly the CashFlowCoverage covenant. ${ }^{328}$ Therefore, in line with evidence from interviews and empirical results, transacting parties heavily negotiate the D/EBITDA covenant headroom, which is the first to show a signal of shifting control rights.

\footnotetext{
${ }^{327}$ Demiroglu/James (2010b) report stricter covenant levels over time. However, they draw their conclusion based on the covenant thresholds, while this study analyzes the covenant headroom. This analysis supports their finding of declining covenant thresholds.

${ }^{328}$ Note that this implication is based on the assumption that the elasticity between EBITDA and unlevered free cash flow is equal to 1, i.e. $\triangle \mathrm{EBITDA}=\triangle \mathrm{FCF}$. While in the general corporate world cash flows are more volatile than EBITDA, the author believes that in leveraged buyouts deteriorating EBITDA levels increase the probability of a reduction of capital expenditures in order to avoid covenant violations and therefore smooth cash flow levels in downside scenarios.
} 
Over time, with decreasing leverage, this picture gradually changes, seen also in other academic research. ${ }^{329}$ In year three after the transaction the EBITDA/I covenant is the covenant most likely to be violated. In later years $(t>4)$ and increasing repayments of senior bullet $\mathrm{B}$ and $\mathrm{C}$ tranches as well as mezzanine redemption, the cash flow covenant becomes the strictest covenant (not shown in analysis for the sake of brevity). However, if the D/EBITDA covenant is not violated during the early years, the overall leverage is reduced while equity is increased leading to lower financial risk. Apparently, covenant restrictiveness is most important in the early years of the transaction, which is supported by conversations with bankers.

\begin{tabular}{|c|c|c|c|c|c|c|c|}
\hline \multirow[b]{2}{*}{ Forecast year } & \multirow[b]{2}{*}{ Statistics } & \multicolumn{3}{|c|}{ Headroom Mean and Median } & \multicolumn{3}{|c|}{ t-values } \\
\hline & & $\begin{array}{c}\text { D/EBITDA } \\
\text { (as \%) }\end{array}$ & $\begin{array}{c}\text { EBITDA/I } \\
\text { (as \%) }\end{array}$ & $\begin{array}{c}\text { CashFlow } \\
\text { Coverage } \\
\text { (as \%) } \\
\end{array}$ & $\begin{array}{c}\text { CashFlow } \\
\text { Coverage vs. } \\
\text { D/EBITDA } \\
\text { t-value } \\
\end{array}$ & $\begin{array}{c}\text { EBITDA/I } \\
\text { vs. } \\
\text { D/EBITDA } \\
\text { t-value } \\
\end{array}$ & $\begin{array}{c}\text { CashFlow } \\
\text { Coverage vs. } \\
\text { EBITDA/I } \\
\text { t-value } \\
\end{array}$ \\
\hline \multirow[t]{3}{*}{$\mathrm{t}=1$} & Mean & 23.8 & 24.8 & 31.3 & $5,1 * * *$ & $2,1 * *$ & $3,8 * * *$ \\
\hline & Median & 22.6 & 23.9 & 28.6 & & & \\
\hline & $n$ & 124 & 103 & 123 & & & \\
\hline \multirow[t]{3}{*}{$t=2$} & Mean & 27.6 & 25.9 & 30.6 & $2,6 * * *$ & 0.5 & $3,0 * * *$ \\
\hline & Median & 25.5 & 25.0 & 29.8 & & & \\
\hline & $n$ & 124 & 103 & 123 & & & \\
\hline \multirow[t]{3}{*}{$t=3$} & Mean & 31.9 & 28.4 & 33.1 & 1.0 & -0.6 & $2,4 * * *$ \\
\hline & Median & 28.4 & 26.1 & 32.0 & & & \\
\hline & $n$ & 123 & 103 & 123 & & & \\
\hline $\mathrm{t}=3$ versus $\mathrm{t}=1$ & z-scores & $5.25 * * *$ & $2.67 * * *$ & $1.82 *$ & & & \\
\hline
\end{tabular}

Table 21: $\quad$ Headroom comparison of the typical LBO covenants Source: $\quad$ LBO dataset

To sum up, the analysis shows that there is a financial covenant pecking order. The D/EBITDA covenant seems to be the most important financial covenant and the D/EBITDA headroom, particularly during the first two years, is the crucial determinant of the restrictiveness of financial covenants and therefore heavily negotiated between private equity sponsors and lead arrangers.

Consequently, the D/EBITDA headroom during the first two years after loan origination is the primary measure for covenant restrictiveness and consequently serves as the

${ }^{329}$ Cf. Demiroglu/James (2010b), Ivashina/Kovner (2010). 
primary dependent variable in the empirical analysis of financial covenant restrictiveness. Figure 16 shows the distribution of the most restrictive D/EBITDA headroom. For the average deal the most restrictive covenant during the first two years after the transaction is $23.2 \%$ (median $22.5 \%$ ) with a standard deviation of $6.6 \%$. This variable will be used as the primary measure for financial covenant restrictiveness.

In addition, the headroom of the CashFlowCoverage covenant as well as creditor rights dilution will be analyzed to get a comprehensive view on covenant restrictiveness.

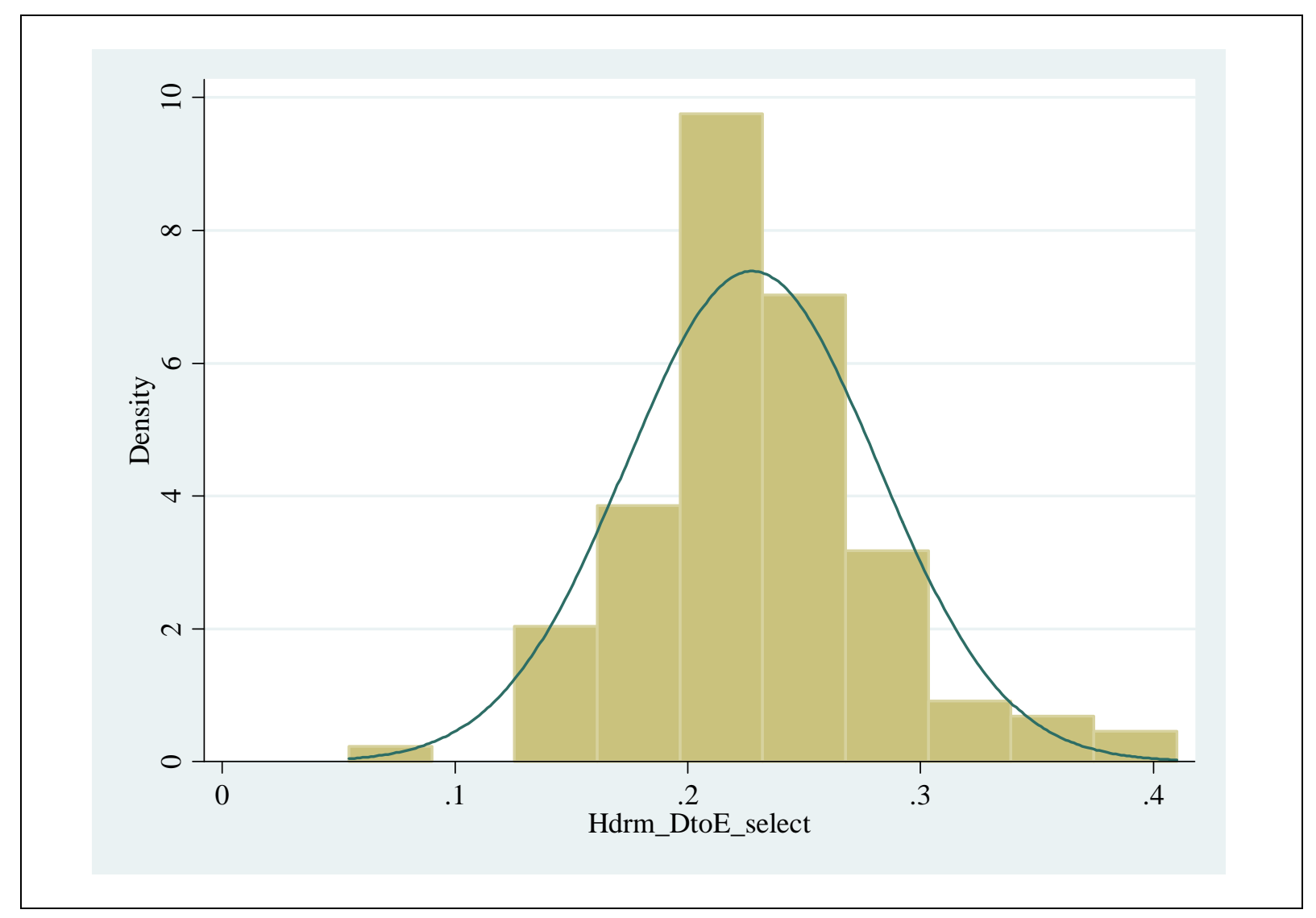

Figure 16: Minimum D/EBITDA headroom

Source: $\quad$ LBO dataset

\subsubsection{Explanatory Variables}

\subsubsection{Target related}

Having described the distribution primary dependent variable over time and in the cross-section, the following paragraphs define and describe the independent variables 
to test the hypotheses, clustered according to target, transaction, sponsor, lead arranger and macroeconomic related variables.

Two different measures are generally applied to measure the size of the firm, either sales or total assets of the firm. In a transaction environment, like a private equity transaction, total assets equal the value of the firm because the difference of ex ante assets and the transaction value is accounted for as goodwill on the new balance sheet of the buyout company. Therefore, the variable total assets mirrors the transaction size, which is correlated to the size of the firm but also depends on other factors, like debt availability. Consequently, the cross-sectional analysis utilizes firm sales before transaction as the proxy for firm size. Results are robust when including total assets excluding goodwill. Sales data is directly taken from the agreed financing case. Table 22 reports the distribution of sales in the LBO dataset. The average company has sales of $€ 567$ million (median €276.4 million). For the regressions, the continuous size variable is transformed into a categorical variable. The reasoning behind this is that private equity groups as well as lead arrangers focus on specific firm size segments.

There exists a wide range of empirical measures in the literature to proxy firm growth. The intent of a growth variable is to measure the expected growth of a firm, not realized growth. Therefore, variables describing future growth are preferable to metrics that proxy historical growth. A prominent measure that accounts for future growth options is the market-to-book ratio, known as Tobin's Q. ${ }^{330}$ In a private equity transaction, which is not a P2P or PIPE, the book value of equity equals the market value of equity at transaction and therefore Tobin's $\mathrm{Q}$ would be equal to one. Other measures like $R \& D$ expenditures and capital expenditures also have predictive power for growth.

In contrast to these noisy indirect measures, this thesis applies the most direct measure for expected firm growth, the expectation of lenders and private equity sponsors on the EBITDA growth of the firm. The variable measures the expected annual growth rate of EBITDA for the three years after the transaction. The results of the analysis are robust

${ }^{330}$ Cf. Rajan/Zingales (1995), p. 1453. 
against the inclusion of other growth variables like e.g. sales growth. Table 22 reports the distribution of the expected EBITDA growth in the LBO dataset. The average company is expected to grow its EBITDA by $9.3 \%$ for every year following the three years after the transaction (median 8.0\%).

Compared to firm growth, the measurement of profitability is homogeneous across empirical studies. Typically the profitability of firms is calculated by dividing operating income by a measure of size. This study uses EBITDA as a proxy for operating income and sales as the measure for firm size, both at the date of the transaction. The analysis is robust against the inclusion of EBITDA to total assets. Table 22 reports the distribution of EBITDA to sales in the LBO dataset. The average company has a profitability of $17.6 \%$ at transaction date (median $15.7 \%$ ).

\begin{tabular}{|lccrrrrr|}
\hline & Obs. & Unit & 25\% & Median & Mean & $75 \%$ & SD \\
\hline Target related & & & & & & & \\
\multicolumn{1}{c}{ Sales } & & & & & & & \\
EBITDA & 130 E millions & 77.2 & 276.4 & 568.6 & 651.0 & 859.5 \\
Expected EBITDA growth & 130 E millions & 17.2 & 34.9 & 75.5 & 94.9 & 100.3 \\
EBITDA to sales & 130 & $\%$ & 5.1 & 8.0 & 9.3 & 12.3 & 6.1 \\
Business risk & 130 & $\%$ & 11.5 & 15.7 & 17.6 & 20.8 & 9.8 \\
Fixed to total assets & 130 & bps & 109.2 & 148.3 & 210.2 & 248.8 & 245.5 \\
& 130 & $\%$ & 36.5 & 60.8 & 60.3 & 76.9 & 36.2 \\
\hline
\end{tabular}

Table 22: $\quad$ Descriptive statistics for target related variables Source: LBO dataset

Measuring the risk of a private equity transaction is not trivial. Usually, empirical studies rely on the historical volatility of operating income, like e.g. EBITDA, of the unlevered risk of the firm over a period of 5-20 years. However, there are two caveats to this measure in the context of private equity transactions. First, private equity sponsors take over control and argue that historical volatility is not predictive for future volatility due to better management. Second, historical volatility of EBITDA is not observable for private companies, which constitute the majority of private equity targets. Consequently, this study uses the implied volatility of operating income of the unlevered target firm, known as business risk. Specifically, business risk is the per- 
centage change of EBITDA caused by a change of 1 percentage point in sales over the first three years after transaction. Table 22 reports the distribution of the business risk variable in the LBO dataset. The average company has a business risk of 210 bps (median 148 bps). This means that a decrease of firm sales by 1 percentage point decreases EBITDA by 2.1 percentage points.

There is great homogeneity among academic studies in measuring the tangibility of a firm. The typical metric is the share of fixed tangible assets to total book assets (including goodwill). The variable fixed tangible assets is defined as property, plant and equipment. This study follows the accepted approach. Table 21 reports the distribution of fixed to total assets in the LBO dataset. The average company has a share of fixed assets of $60.3 \%$ at transaction date (median $60.8 \%$ ).

\subsubsection{Transaction related}

Similar to AXELSON et al. (2010) this study uses two different measures for leverage: net debt divided by earnings before interest and depreciation (D/EBITDA) and net debt divided by the enterprise value (D/EV), both at transaction date. ${ }^{331}$ The leverage of the LBOs in the sample (Table 23) exhibits comparable leverage levels to previous studies. For example AXELSON et al. (2010) report a mean D/EBITDA of 5.6x and a mean D/EV of $69 \%$ for 1142 LBOs. When conditioning their sample on (1) Western Europe setting and (2) on private-to-private transactions (i.e. deals which are usually undersampled in commercial databases due to their lower visibility) their leverage statistics are likely to be highly similar to the ones of the LBO dataset used in this study. The average LBO in this dataset has a D/EBITDA multiple of 4.4x and finances 66\% of the enterprise value with debt (median 4.3x and 66.3\%). Both leverage measures show considerable variation with a standard deviation of 1.5x for D/EBITDA and 9.6 percentage points for $\mathrm{D} / \mathrm{EV}$.

As the typical LBO includes several different tranches and contingent facilities, there are multiple ways to measure interest cost in LBO transactions. All senior spreads are based on the Term A spread plus a certain additional spread (e.g. Term B spread

\footnotetext{
${ }^{331}$ At transaction net debt equals gross debt, as the enterprise value is typically cash free.
} 
equals Term A plus 50 bps). Additionally, Term A spreads are not capital structure blended. Therefore, the Term A spread might be an appropriate measure for interest costs. Table 23 reports the Term A spread for the LBO dataset. Interestingly, Term A spread (as well as all other tranches) does not show great variation (almost all Term A spread are set to 225 bps) and seems to be standardized in European LBO transactions, which is also stated by POLENBERG/LUKATSKY/GUPTE (2010).

Another widely used measure for interest costs is the weighted all-in-drawn spread (excluding contingent facilities). It is calculated as the sum of the spreads of different debt tranches weighted by their share of the debt package. Table 23 reports the distribution of all-in-drawn spread in the LBO dataset. The average LBO firm has to pay a total spread of 356 bps for its debt package (median 368 bps). However, the all-indrawn spread is merely a function of the capital structure decision. In order to reflect pure interest cost negotiations, the cross-sectional analysis includes the Term A spread.

\begin{tabular}{|c|c|c|c|c|c|c|c|}
\hline & Obs. & Unit & $25 \%$ & Median & Mean & $75 \%$ & SD \\
\hline \multicolumn{8}{|l|}{$\underline{\text { Transaction related }}$} \\
\hline $\mathrm{D} / \mathrm{EBITDA}(\mathrm{t}=0)$ & 130 & $x$ & 3.3 & 4.3 & 4.4 & 5.4 & 1.5 \\
\hline $\mathrm{D} / \mathrm{EV}(\mathrm{t}=0)$ & 130 & $\%$ & 58.9 & 66.3 & 65.6 & 72.5 & 9.6 \\
\hline Term A spread & 126 & $\%$ & 2.25 & 2.25 & 2.25 & 2.25 & 0.19 \\
\hline Weighted senior spread (excluding contingent facilities) & 130 & $\%$ & 2.51 & 2.65 & 2.67 & 2.79 & 0.29 \\
\hline All-in-drawn spread (excluding contingent facilities) & 130 & $\%$ & 2.61 & 3.68 & 3.56 & 4.26 & 0.96 \\
\hline Maturity Term A & 126 & no. & 84 & 84 & 82 & 84 & 5.9 \\
\hline Share of bank debt & 130 & $\%$ & 21.9 & 30.0 & 32.1 & 39.5 & 14.0 \\
\hline Creditor rights dilution & 130 & no. & 0.0 & 1.0 & 1.3 & 2.0 & 1.5 \\
\hline
\end{tabular}

Table 23: $\quad$ Descriptive statistics for transaction related variables Source: LBO dataset

The share of bank debt, in accordance with section 2.3.1 and in line with DEMIROGLU/JAMES (2010b), is measured as the sum of Term A loan and revolver divided by the total amount of acquisition loans plus revolver. Table 23 reports the distribution of the share of bank debt in the LBO dataset. The average LBO firm has a share of bank debt of 32.1\% (median 30.0\%).

The functioning of financial covenants may be deterred if loan agreements contain clauses which alleviate the primary purpose to transfer control rights from borrowers 
to lenders in the case of a covenant breach. In these cases covenant enforcement is limited. In order to measure the effect of such clauses on financial covenant restrictiveness the author constructs a creditor rights dilution index. The index aggregates elements of the credit agreement that reduce the rights of the lender in case of a covenant violation. Table 23 reports the distribution of the creditor rights index in the LBO dataset. An average LBO receives 1.3 clauses that dilute creditor rights (median 1.0).

To be more explicit on this proprietary variable, Table 24 shows the development of the individual components of the creditor rights dilution index and the scores of the index over time. A score of one is assigned when each of the following limitations of senior lender rights occur: First, waivers for violations of financial covenants do not need the consent of all senior creditors, e.g. supermajorities (66 or $75 \%$ of senior creditors) are sufficient to waive a covenant breach (this clause is also known as 'supermajority'). Second, in case that a creditor dissents to a waiver of a covenant breach, the dissenting creditor might be simply replaced by redeeming the outstanding principal (this clause is also known as 'yank-the-bank'). Third, claims of creditors in case of covenant breach are only valid throughout a certain number of business days, typically 15 (also known as 'snooze \& lose'). Fourth, in case of covenant breach the private equity sponsor has the right to 'cure' the breach by injecting equity into the borrowing company and reduce outstanding debt by this amount (also known as 'equity cure right'). Fifth, an even more sponsor friendly type of 'equity cure right', the sponsor has the right to 'cure' a financial covenant breach by injecting capital into the borrowing company but the amount is allocated to EBITDA for the next 12 months, which reduces the probability of financial covenant breaches considerably in this period. The index ranges from 0 (no limits on creditor rights in breach) to 5 (strong limitations of creditor rights) and is constructed at deal level.

One recognizes that the boom and bust pattern also holds for the creditor rights dilution index. From 2000 to 2003 PE groups were not as likely to include clauses that limit the rights of creditors in the case of a covenant breach. However, during the boom times of 2004 to 2007, PE groups benefited from their market power and increased borrower friendly clauses in their credit agreements. Interestingly, the aggre- 
gated creditor rights dilution index shows that deals closed in 2008 even included more borrower friendly clauses in the credit agreements.

This might have two different explanations. First, the respective clauses have different values to creditors and debtors. Some clauses grew to standard, like the yank-the-bank clause, which also sometimes helps banks to get rid of non-consenting banks. However, the more likely explanation is that during the credit crisis, only very large and reputable PE groups were able to receive financing for exceptionally good target firms, both being potential drivers of the negotiation power towards lenders.

\begin{tabular}{|c|c|c|c|c|c|c|c|}
\hline Deal year & $\begin{array}{c}\text { Number of } \\
\text { deals }\end{array}$ & $\begin{array}{c}\text { Supermajorities } \\
\text { (frequ.) }\end{array}$ & $\begin{array}{c}\text { Yank the bank } \\
\text { (frequ.) }\end{array}$ & $\begin{array}{c}\text { Snooze and lose } \\
\text { (frequ.) }\end{array}$ & $\begin{array}{c}\text { Equity cure right } \\
\text { (injection used to } \\
\text { pay back debt) } \\
\text { (frequ.) }\end{array}$ & $\begin{array}{c}\text { Equity cure right } \\
\text { (injection used to } \\
\text { increase EBITDA) } \\
\text { (frequ.) }\end{array}$ & $\begin{array}{c}\text { Creditor rights } \\
\text { dilution index } \\
\text { (mean) }\end{array}$ \\
\hline 2000 & 1 & 0 & 0 & 0 & 0 & 0 & 0 \\
\hline 2001 & 2 & 0 & 0 & 0 & 0 & 0 & 0 \\
\hline 2002 & 6 & 1 & 1 & 0 & 0 & 0 & 0.33 \\
\hline 2003 & 7 & 0 & 1 & 1 & 0 & 0 & 0.29 \\
\hline 2004 & 20 & 3 & 9 & 4 & 3 & 2 & 1.05 \\
\hline 2005 & 28 & 2 & 10 & 6 & 8 & 0 & 0.96 \\
\hline 2006 & 30 & 9 & 9 & 5 & 13 & 2 & 1.23 \\
\hline 2007 & 29 & 11 & 14 & 10 & 21 & 7 & 2.03 \\
\hline 2008 & 7 & 2 & 7 & 3 & 7 & 0 & 2.38 \\
\hline Total & 130 & 28 & 51 & 29 & 52 & 11 & 1.29 \\
\hline
\end{tabular}

Table 24: Composition of the creditor rights dilution index over time Source: $\quad$ LBO dataset

\subsubsection{Sponsor related}

Existing literature proposes several proxies to measure private equity group reputation. ${ }^{332}$ This study constructs all relevant measures, which are described in the following. A common measure for PE group reputation is the size of the PE group measured by assets under management ( $P E$ group size). ${ }^{333}$ This study constructs the size variable by aggregating the capital committed to the funds of the PE group over the last five

\footnotetext{
${ }^{332}$ For an overview see Demiroglu/James (2010b).

${ }^{333}$ Cf. among others see Demiroglu/James (2010b).
} 
years before the transaction. This procedure mirrors the one applied by Private Equity International. The fund data is obtained from Thomson Venture Economics (TVE). Table 25 Panel A reports the distribution for the PE group size variable in the LBO dataset. The average PE group had €3 billion under management at the date of the deal (median $€ 1.3$ billion). Due to the inclusion of very large PE groups like e.g. KKR, Bain Capital, Goldman Sachs Capital Partners, Carlyle, among others, the standard deviation is $€ 5$ billion.

Panel A: Descriptive statistics of LBO sample

\begin{tabular}{lccrrrrr}
\hline & Obs. & Unit & $25 \%$ & Median & Mean & $75 \%$ & SD \\
\hline & \multicolumn{1}{c}{} & & & & & & \\
Sponsor related & & & & & & & \\
\hline PE group size & 130 E millions & 91.3 & $1,316.4$ & $3,033.5$ & $3,936.4$ & $4,961.1$ \\
PE group lifetime & 130 & no. & 6.0 & 13.0 & 15.6 & 24.0 & 12.3 \\
PE group number of deals & 130 & no. & 5.0 & 11.0 & 17.4 & 28.0 & 17.3 \\
BR volume & 130 & $\%$ & $0 \%$ & 16.3 & 23.2 & 34.7 & 26.5 \\
BR number of deals & 130 & $\%$ & $0 \%$ & 13.9 & 18.8 & 25.0 & 23.1 \\
BR number of deals (abs) & 130 & no. & 0.0 & 1.5 & 3.3 & 4.0 & 4.7 \\
& & & & & & &
\end{tabular}

Panel B: Correlation matrix for reputation measures

Information asymmetry measure

\begin{tabular}{lcccll}
\cline { 1 - 3 } Information asymmetry measure & $(1)$ & $(2)$ & (3) & & Description \\
\cline { 1 - 3 } (1) PE group size & 1 & & & LN(1 + PE group size $)$ \\
(2) PE group lifetime & $0.69 * * *$ & 1 & & & LN(1 + PE group lifetime $)$ \\
(3) PE group number of deals & $0.62 * * *$ & $0.77 * * *$ & 1 & & LN(1 + PE group number of deals $)$
\end{tabular}

Table 25: Descriptive statistics for sponsor related variables Source: $\quad$ LBO dataset

Another way to measure PE group reputation is proposed by GOMPERS/LERNER (1999). They argue that investors learn about the characteristics and behavior of private equity organizations over time. Therefore this study also uses the lifetime of a PE group as another proxy for reduced information asymmetry costs (PE group lifetime). 
The age of the private equity organization at transaction date is aggregated by using the fund database of TVE. The year of the first fund is then compared to available public information coming directly from the PE group. If the data from TVE and the public information do not match, the study uses the information provided directly from the PE group. Panel A reports the distribution for the $P E$ group lifetime variable in the LBO dataset. The average PE group in the sample has a lifetime of 15.6 years (median 13.0).

The frequency of interactions with the syndicated loan market serves as a third measure for PE group reputation (PE group number of deals). The number of transactions a PE group was able to complete before the respective deal in the sample approximates the frequency of interactions. The variable counts all deals recorded in TVE and MergerMarket during three years prior to the transaction. Table 25 Panel A reports the distribution for the PE group number of deals variable in the LBO dataset. The average deal in the sample was sponsored by a PE group which completed 17.4 deals before the respective transaction (median 11.0).

Table 25 Panel B presents the correlation matrix for the measures of information asymmetry costs. The individual measures have been logged because the economic characteristics suggest a diminishing marginal effect of the variables. For example, a completed deal is more important when the PE group has only two completed deals as compared to when it has completed 22 deals in the last years.

The analysis shows that the three measures for private equity group reputation are highly and significantly correlated (between 0.62 and 0.77 all being significant at the $1 \%$ level). Although there is a high correlation, the regression analysis tests the results for robustness for each of the reputation proxies. As reputation is a latent construct, the authors also constructed a latent reputation variable that included the information of all three proxies. However, since results remained robust and the economic interpretation of the reputation proxies is easier, this study does not report the results for the latent variable. 
Similar to IVASHINA/KOVNER (2010) and BHARATH et al. (2007) this study measures bank relationship by the Euro value of loans in the previous five years underwritten by the bank functioning as lead arranger divided by the total Euro value of all loans sponsored by the respective private equity group as reported in Dealscan ( $B R$ volume). In case more than one bank functioned as lead arranger, the highest relationship value is selected. Table 25 Panel A reports the distribution for the $B R$ volume variable in the LBO dataset. The average deal is sponsored by a PE group that has a $B R$ volume of $23.2 \%$ with the bank functioning as the lead arranger (median of $16.3 \%$ ). This means, the average deal is sponsored by a PE group that financed $23.2 \%$ of its previous loans with the same lead arranging bank of the deal.

For reasons of robustness, the author also computes an analogous bank relationship variable that results from dividing the number of loans of the lead arranging bank sponsored by the respective PE group in the five years prior the transaction divided by the total number of loans sponsored by this private equity group as reported in Dealscan, Thomson Venture Economics and Mergermarket (BR number of deals). Table 25 Panel A reports the distribution for the BR number of deals variable in the LBO dataset. On average BR number of deals equals 18.8\% (median of 13.9\%).

Additionally, a simple count variable is aggregated (which is logged in the regression), summing the number of loans underwritten in the previous five years by the respective lead arranging bank (BR number of deals (abs)). As the reduction of information asymmetry is a learning process, it may likely result from the absolute frequency of interactions between bank and the PE group. However, as noted by IVASHINA/KOVNER (2010) this measure for bank relationship conflates with measures of PE group reputation. Table 25 Panel A reports the distribution for the BR number of deals (abs) variable in the LBO dataset. The average PE group in the sample completed 3.3 transactions in the previous five years before the respective deal with the respective lead arranging bank (median 1.5).

One obvious point of critique is that the variables measuring banking relationship merely capture the view of the PE group. More specifically, the variables measure how the PE group evaluates the relationship to the bank but not how the bank sees the PE 
group what would be more important in the eyes of the author. These variables measure how important the bank is for the PE group but not how important the PE group is for the bank. However, due to the incomplete data on historical loans of the banks, this analysis is not possible for this dataset.

\subsubsection{Lead Arranger related}

The final hold is the amount of debt that the credit committee decides to hold on the lead arranger's book. Clearly, the larger the debt package the more will be attributed to the lead arranger in absolute terms. Consequently, the relevant variable for the crosssectional analysis is the share of the debt package that the lead arranger intends to hold on its book. Sometimes the demand for a specific loan changes between the credit committee determined a target final hold and the point in time when the loan is actually syndicated. This is a significant risk banks have to take. For example, as the credit crisis started to spread and the demand for private equity sponsored loans dried up, many loans were hardly placeable and had to remain on the lead arrangers' books. The intended final hold also includes the contingent facilities, like the revolving or capital expenditure facilities. The remainder of the debt package is either syndicated to participants or placed in the form of bonds with the public markets. This definition is in line with SUFI (2007). Table 26 reports the distribution for the Relative final hold variable in the LBO dataset. On average the lead arranger intended to hold $31.1 \%$ of the debt package on its books, which is in line with the $28.5 \%$ of SUFI (2007). One caveat of this variable is that the dataset only contains 83 observations as one bank was not willing to share this information.

\begin{tabular}{|c|c|c|c|c|c|c|c|}
\hline & Obs. & Unit & $25 \%$ & Median & Mean & $75 \%$ & SD \\
\hline \multicolumn{8}{|l|}{ Lead arranger related } \\
\hline Final hold & 83 & $\epsilon$ millions & 0.0 & 25.0 & 28.4 & 40.0 & 30.9 \\
\hline Relative final hold & 83 & $\%$ & 7.5 & 14.3 & 31.1 & 52.6 & 32.9 \\
\hline
\end{tabular}

Table 26: Descriptive statistics for lead arranger related variables Source: $\quad$ LBO dataset 


\subsubsection{Macroeconomic related}

To control for market conditions the analysis includes the average credit risk spread between AAA and BB corporate bonds during the month of the transaction. This information of daily bond yields is obtained from Merrill Lynch Global Index System. ${ }^{334}$ This type of spread is widely accepted to mirror the risk aversion in the credit market, especially for leveraged loans. ${ }^{335}$ The average spread between AAA and BB rated bonds in the sample is 253.2 bps with a standard deviation of 171.5 bps. Furthermore, results are controlled for year and industry fixed effects in the robustness section to eliminate time variations in market conditions.

\begin{tabular}{|c|c|c|c|c|c|c|c|}
\hline & Obs. & Unit & $25 \%$ & Median & Mean & $75 \%$ & SD \\
\hline \multicolumn{8}{|c|}{$\underline{\text { Macroeconomic related }}$} \\
\hline Credit spread & 130 & bps & 140.1 & 218.4 & 253.2 & 264.3 & 171.5 \\
\hline
\end{tabular}

Table 27: $\quad$ Descriptive statistics for macroeconomic related variables Source: $\quad$ LBO dataset

\subsection{Determinants of Financial Covenant Restrictiveness}

\subsubsection{Difference in Means}

In a simple univariate analysis this section conducts simple independent t-tests of differences in means. Therefore, the sample is grouped into two equally sized groups according to the D/EBITDA headroom: deals with D/EBITDA headroom below 22.5\% are classified as tight D/EBITDA covenant and deals with a D/EBITDA headroom above $22.5 \%$ are classified as loose D/EBITDA covenant. Table 28 compares the means of these two groups for different variables and reports the t- and p-values to assess statistical significance. To test for robustness if the normality assumption of the

\footnotetext{
${ }^{334}$ See http://www.mlindex.ml.com/gispublic/default.asp.

${ }^{335}$ Cf. Demiroglu/James (2010b).
} 
t-test would not hold, the non-parametric Mann-Whitney U-test is reported. However, the results of the two tests are predominantly in line ${ }^{336}$.

In terms of target related factors the analysis shows that loans with looser covenants are larger in size (statistically not significant), have stronger expected growth (statistically significant at 5\% level), are slightly more profitable (statistically not significant), are exposed to higher business risk (statistically not significant) and have a higher share of fixed assets (statistically not significant).

In the category of transaction related factors, the data shows that deals with looser D/EBITDA covenants have lower leverage levels, whereas leverage expressed in $\mathrm{D} / \mathrm{EBITDA}$ is not statistically different but $\mathrm{D} / \mathrm{EV}$ is statistically different at the $10 \%$ level. In terms of spreads, loans with loose D/EBITDA headroom contain higher interest payments (statistically not significant), have longer term A maturities (statistically not significant) and are financed with a lower share of bank debt (statistically not significant). The t-test indicates that loans with looser D/EBITDA headroom contain more dilutive creditor rights, being statistically significant at the $10 \%$ level. However, the Kolmogorov-Smirnov test shows that the creditor rights dilution index is not normally distributed on statistically significant levels. Hence, the rank sum test statistic does not show any statistical significant effect of dilutive creditor rights on the tightness of financial covenants.

In terms of sponsor related determinants, deals with looser D/EBITDA headroom are sponsored by larger PE groups (statistically significant at the 1\% level) and the relationship between the financing bank and the PE group is closer (statistically not significant).

Looking at lead arranger related factors banks hold less of loans with loose D/EBITDA headroom (statistically not significant). Finally, in a credit environment with higher risk aversion, i.e. higher credit spread, the D/EBITDA headroom is higher

\footnotetext{
${ }^{336}$ If the two tests show different results, the variable is tested for normality on the basis of Kolmogorov-Smirnov goodness of fit test. If the hypothesis of normality can be rejected on typical statistical levels, the Mann-Whitney U-test is the appropriate test.
} 
(statistically not significant). To test these indicative findings in a more robust way, the following section conducts multiple regression analysis.

\begin{tabular}{|c|c|c|c|c|c|c|c|c|}
\hline & Unit & $\begin{array}{c}\text { Tight } \\
\text { D/EBITDA } \\
\text { covenant }\end{array}$ & $\begin{array}{c}\text { Loose } \\
\text { D/EBITDA } \\
\text { covenant }\end{array}$ & t-value & p-value & & $\begin{array}{l}\text { Mann- } \\
\text { Whitney } \\
\text { U-Test } \\
\text { (p-value) }\end{array}$ & \\
\hline \multicolumn{9}{|l|}{ Target related } \\
\hline Sales & $\epsilon$ millions & 476.2 & 706.2 & -1.48 & 0.14 & & 0.74 & \\
\hline Expected EBITDA growth 3 years & $\%$ & $8 \%$ & $11 \%$ & -2.26 & 0.03 & $* *$ & 0.05 & $* *$ \\
\hline EBITDA to sales & $\%$ & $17 \%$ & $18 \%$ & -0.60 & 0.55 & & 0.25 & \\
\hline Business risk & bps & 2.0 & 2.3 & -0.50 & 0.62 & & 0.40 & \\
\hline Fixed to total assets & $\%$ & $59 \%$ & $61 \%$ & -0.36 & 0.72 & & 0.79 & \\
\hline \multicolumn{9}{|l|}{$\underline{\text { Transaction related }}$} \\
\hline D/EBITDA $(\mathrm{t}=0)$ & $x$ & 4.5 & 4.4 & 0.20 & 0.84 & & 0.84 & \\
\hline $\mathrm{D} / \mathrm{EV}(\mathrm{t}=0)$ & $\%$ & 0.7 & 0.6 & 1.90 & 0.06 & * & 0.07 & * \\
\hline Term A spread & $\%$ & 2.2 & 2.3 & -0.43 & 0.67 & & 0.98 & \\
\hline Weighted senior spread (excl. cont. fac.) & $\%$ & 2.7 & 2.7 & -0.87 & 0.38 & & 0.56 & \\
\hline All-in-drawn spread (excl. cont. fac.) & $\%$ & 3.5 & 3.6 & -0.35 & 0.73 & & 0.94 & \\
\hline Maturity Term A & no. & 81.7 & 82.9 & -1.17 & 0.24 & & 0.34 & \\
\hline Share of bank debt & $\%$ & $33 \%$ & $30 \%$ & 1.22 & 0.23 & & 0.21 & \\
\hline Creditor rights dilution & no. & 1.1 & 1.6 & -1.68 & 0.10 & $*$ & 0.17 & \\
\hline \multicolumn{9}{|l|}{ Sponsor related } \\
\hline PE group size & logged & 5.3 & 6.7 & -2.57 & 0.01 & $* * *$ & 0.01 & $* * *$ \\
\hline BR volume & $\%$ & $26 \%$ & $28 \%$ & -0.38 & 0.71 & & 0.61 & \\
\hline \multicolumn{9}{|l|}{$\underline{\text { Lead arranger related }}$} \\
\hline Relative final hold & $\%$ & $32 \%$ & $24 \%$ & 1.05 & 0.30 & & 0.11 & \\
\hline \multicolumn{9}{|l|}{ Macroeconomic related } \\
\hline Credit spread & bps & 232 & 266 & -1.14 & 0.26 & & 0.22 & \\
\hline
\end{tabular}

Table 28: $\quad$ Mean comparison test of D/EBITDA covenant restrictiveness Source: $\quad$ LBO dataset

\subsubsection{Multiple Regression Analysis}

This section tests the hypotheses developed in section 5. Table 29 and Table 30 reports 16 models to test the developed hypotheses (model 1-14) on the determinants of financial covenant restrictiveness and check for the robustness of results (model 15 and 
16). ${ }^{337}$ The coefficients are not standardized in order to facilitate an economic interpretation, i.e. what impact has a change by one unit of the independent variable on the dependent variable. Standardized regressions are reported in the Appendix.

Since the D/EBITDA covenant is the most important covenant in LBOs, the D/EBITDA covenant headroom is typically the heaviest negotiated item during the covenant setting process. The dependent variable is defined as the most restrictive, i.e. smallest, headroom of the D/EBITDA covenant in the first two years after the transaction. In the vast majority of the cases, the covenant headroom was tightest at the first testing date, typically one year after the transaction. However, there were some cases where the covenant was set tightest in $\mathrm{t}=2$.

Before presenting the results of the analysis, some model characteristics are described. As White- and Breusch-Pagan-tests indicate heteroskedasticity of the estimated residuals, the models apply heteroskedasticity-consistent (Huber-White) standard errors for estimating p-values.

Furthermore, the independent variables used for leverage, profitability and growth raise concerns that the models might suffer from multicollinearity. However, the variance inflation factors (VIF) of these variables are less than 1.28 in all models, suggesting that multicollinearity is not severe.

Although not essential for testing the hypotheses, the models roughly explain $16.5 \%$ to $20.3 \%$ of the variation in the D/EBITDA headroom. ${ }^{338} \mathrm{~F}$-values range from 3.05 to 4.05. Endogeneity problems will be discussed in the robustness section 6.5.3.

In regression (1), the baseline specification, D/EBITDA headroom is modeled as a function of EBITDA to sales, EBITDA growth, D/EBITDA, PE group size and credit risk spread. The following paragraphs describe the results according to the driver categories.

\footnotetext{
${ }^{337}$ The final sample includes 126 observations for the D/EBITDA headroom.

${ }^{338}$ Excluding model 14 that is based on 79 observations and has an $\mathrm{R}^{2}$ of $26.5 \%$.
} 


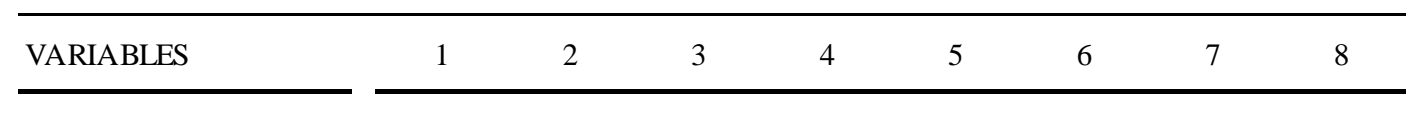

Target related

\begin{tabular}{|c|c|c|c|c|c|c|c|c|}
\hline EBITDA to sales & $\begin{array}{l}0.191 * \\
(1.887)\end{array}$ & $\begin{array}{l}0.194 * \\
(1.888)\end{array}$ & $\begin{array}{l}0.200^{*} \\
(1.894)\end{array}$ & $\begin{array}{l}0.195^{*} \\
(1.908)\end{array}$ & $\begin{array}{l}0.180 * \\
(1.689)\end{array}$ & $\begin{array}{l}0.185^{*} \\
(1.813)\end{array}$ & $\begin{array}{l}0.198 * \\
(1.937)\end{array}$ & $\begin{array}{c}0.195^{* *} \\
(1.989)\end{array}$ \\
\hline EBITDA growth & $\begin{array}{l}0.003^{* *} \\
(2.508)\end{array}$ & $\begin{array}{c}0.003^{* *} \\
(2.596)\end{array}$ & $\begin{array}{l}0.003^{* *} \\
(2.555)\end{array}$ & $\begin{array}{l}0.003^{* *} \\
(2.489)\end{array}$ & $\begin{array}{c}0.002^{* *} \\
(2.013)\end{array}$ & $\begin{array}{c}0.003^{* *} \\
(2.574)\end{array}$ & $\begin{array}{c}0.003^{* * *} \\
(2.807)\end{array}$ & $\begin{array}{c}0.003^{* * *} \\
(2.691)\end{array}$ \\
\hline Small cap dummy & & $\begin{array}{c}-0.004 \\
(-0.265)\end{array}$ & & & & & & \\
\hline Large cap dummy & & $\begin{array}{c}0.005 \\
(0.399)\end{array}$ & & & & & & \\
\hline Fixed to total assets & & & $\begin{array}{c}-0.017 \\
(-1.135)\end{array}$ & & & & & \\
\hline Business risk & & & & $\begin{array}{c}0.001 \\
(0.924)\end{array}$ & & & & \\
\hline
\end{tabular}

\section{Transaction related}

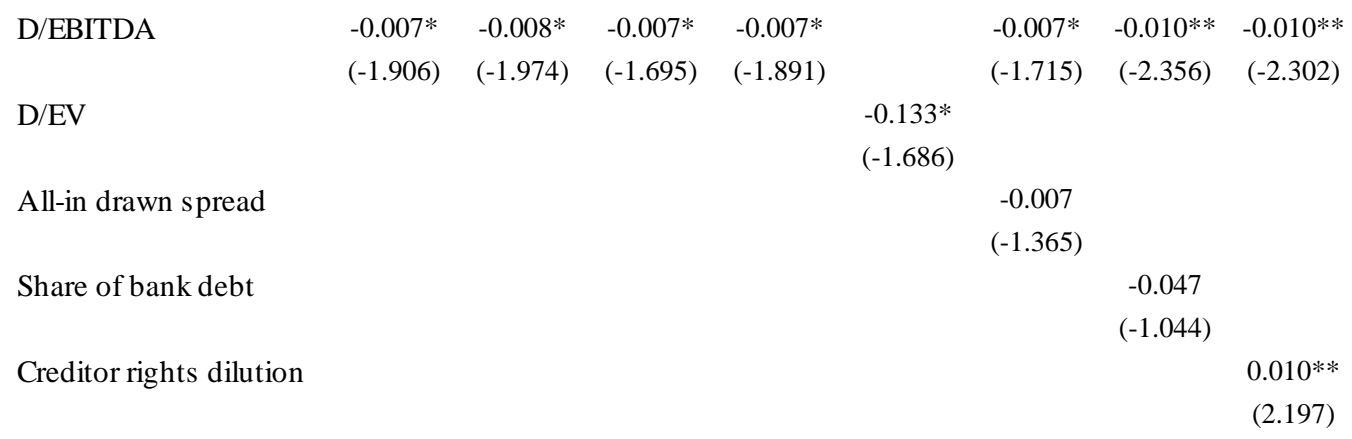

All-in drawn spread

Share of bank debt

Creditor rights dilution

\section{Sponsor related}

PE group size

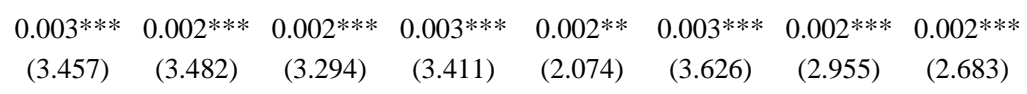

\section{Macroeconomic related}

Credit spread

$$
\begin{array}{cccccccc}
-0.002 & -0.003 & -0.002 & -0.002 & -0.004 & -0.001 & -0.002 & -0.002 \\
(-0.957) & (-1.179) & (-0.799) & (-0.972) & (-1.417) & (-0.721) & (-0.895) & (-0.814)
\end{array}
$$

\section{Fixed effects}

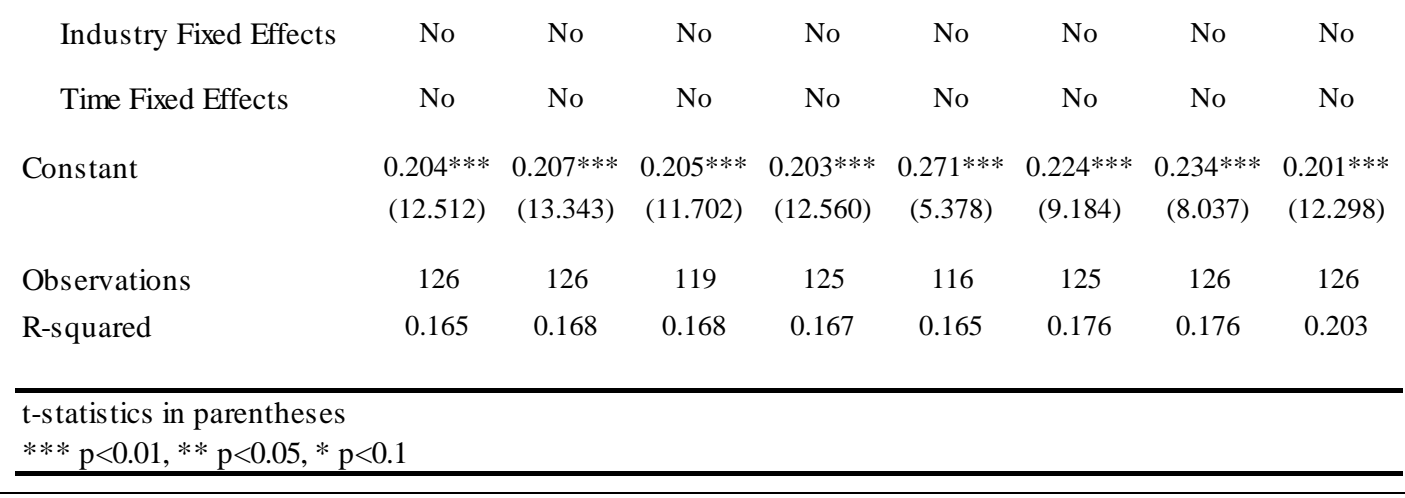

Table 29: $\quad$ Determinants of D/EBITDA headroom I/II Source: $\quad$ LBO dataset 


\begin{tabular}{lcccccccccc}
\hline VARIABLES & 9 & 10 & 11 & 12 & 13 & 14 & 15 & 16 \\
\cline { 5 - 10 } Target related & & & & & & & & & \\
\multirow{2}{*}{ EBITDA to sales } & $0.179^{*}$ & $0.179^{*}$ & $0.190^{*}$ & $0.191^{*}$ & $0.190^{*}$ & $0.278^{* *}$ & $0.216^{* *}$ & $0.191^{*}$ \\
& $(1.737)$ & $(1.753)$ & $(1.879)$ & $(1.889)$ & $(1.877)$ & $(2.037)$ & $(2.098)$ & $(1.904)$ \\
\multirow{2}{*}{ EBITDA growth } & $0.003^{* *}$ & $0.003^{* *}$ & $0.003^{* *}$ & $0.003^{* *}$ & $0.003^{* *}$ & $0.004^{*}$ & $0.003^{* *}$ & $0.003^{* * *}$ \\
& $(2.334)$ & $(2.538)$ & $(2.442)$ & $(2.477)$ & $(2.516)$ & $(1.982)$ & $(2.512)$ & $(2.835)$
\end{tabular}

\section{Transaction related}

\begin{tabular}{|c|c|c|c|c|c|c|c|c|}
\hline D/EBITDA & $\begin{array}{c}-0.006 \\
(-1.608)\end{array}$ & $\begin{array}{l}-0.007^{*} \\
(-1.804)\end{array}$ & $\begin{array}{l}-0.008^{*} \\
(-1.831)\end{array}$ & $\begin{array}{l}-0.008^{*} \\
(-1.930)\end{array}$ & $\begin{array}{l}-0.007^{*} \\
(-1.903)\end{array}$ & $\begin{array}{c}-0.014 * * \\
(-2.112)\end{array}$ & $\begin{array}{l}-0.007^{*} \\
(-1.840)\end{array}$ & $\begin{array}{c}-0.007 * * * \\
(-2.983)\end{array}$ \\
\hline Strict EBITDA def & & & & & & & $\begin{array}{c}-0.018 \\
(-1.099)\end{array}$ & \\
\hline Loose EBITDA def & & & & & & & $\begin{array}{c}0.016 \\
(1.194)\end{array}$ & \\
\hline onsor related & & & & & & & & \\
\hline PE group size & & & & $\begin{array}{c}0.002^{* *} \\
(2.282)\end{array}$ & $\begin{array}{c}0.003^{* * *} \\
(3.439)\end{array}$ & $\begin{array}{c}0.003^{* * *} \\
(2.946)\end{array}$ & $\begin{array}{l}0.002^{* *} \\
(2.474)\end{array}$ & $\begin{array}{c}0.003^{* * *} \\
(3.176)\end{array}$ \\
\hline PE group lifetime & $\begin{array}{c}0.013^{* * *} \\
(2.627)\end{array}$ & & & & & & & \\
\hline PE group number of deal & & $\begin{array}{l}0.011^{* *} \\
(2.358)\end{array}$ & & & & & & \\
\hline BR volume & & & & & $\begin{array}{c}-0.005 \\
(-0.290)\end{array}$ & & & \\
\hline BR number deals (abs) & & & $\begin{array}{l}0.002^{*} \\
(1.906)\end{array}$ & $\begin{array}{c}0.001 \\
(0.792)\end{array}$ & & & & \\
\hline
\end{tabular}

\section{Lead arranger related}

Relative final hold

\section{Macroeconomic related}

$$
\begin{array}{lcccccccc}
\text { Credit spread } & -0.003 & -0.003 & -0.002 & -0.002 & -0.002 & -0.004 & -0.002 & -0.002 \\
& (-1.225) & (-1.191) & (-1.061) & (-1.020) & (-0.918) & (-1.558) & (-1.030) & (-0.818)
\end{array}
$$

\begin{tabular}{|c|c|c|c|c|c|c|c|c|}
\hline Industry Fixed Effects & No & No & No & No & No & No & No & Yes \\
\hline Time Fixed Effects & No & No & No & No & No & No & No & Yes \\
\hline Constant & $\begin{array}{c}0.183^{* * *} \\
(10.244)\end{array}$ & $\begin{array}{c}0.186^{* * *} \\
(10.057)\end{array}$ & $\begin{array}{c}0.206^{* * *} \\
(12.264)\end{array}$ & $\begin{array}{c}0.206^{* * *} \\
(12.193)\end{array}$ & $\begin{array}{c}0.205^{* * *} \\
(12.029)\end{array}$ & $\begin{array}{c}0.222 * * * \\
(8.787)\end{array}$ & $\begin{array}{c}0.199 * * * \\
(12.259)\end{array}$ & $\begin{array}{c}0.204^{* * *} \\
(7.589)\end{array}$ \\
\hline Observations & 126 & 126 & 126 & 126 & 126 & 79 & 125 & 126 \\
\hline R-squared & 0.185 & 0.175 & 0.160 & 0.168 & 0.166 & 0.265 & 0.184 & 0.165 \\
\hline
\end{tabular}

\section{Fixed effects}

Table 30: Determinants of the D/EBITDA headroom II/II Source: $\quad$ LBO dataset 


\subsubsection{Target related}

Model 1 shows that increased profitability, measured as EBITDA/sales ${ }^{339}$, at transaction $(t=0$ ) leads to significantly (at 10\% level) less restrictive covenants, i.e. higher headroom. This finding suggests that lenders consider achieved profitability as a signal that future behavior of management will be positive and therefore lenders grant more flexibility to management in terms of less restrictive financial covenants. An increase in the EBITDA margin by one percentage point or one standard deviation (9.7 percentage points), increases the leverage headroom by about 19 basis points or 187 basis points, respectively. The results for profitability are robust across all models.

Next, the analysis provides evidence that financial covenants are less restrictive for high growth firms, i.e. they receive higher D/EBITDA headroom. This result is significant across all specifications, mainly at the 5\% level. Accordingly, increasing the expected EBITDA growth forecast over the first three years after the buyout by one percentage point or one standard deviation increases the D/EBITDA headroom by 30 basis points or 173 basis points, respectively. Substituting EBITDA growth by expected sales growth yields robust results. ${ }^{340}$ Whereas theory predicts different directions, the author finds direct evidence that shareholders and management of high-growth firms value flexibility more than shareholders of comparable low-growth firms. At first, this finding appears to contradict the results of many scholars, e.g. BILLETT/KING/ MAUER (2007) ${ }^{341}$, who suggest that higher growth firms receive more restrictive covenants. But most past studies evaluate covenant protection by the mere counting of action-restricting covenants in the context of agency theory.

\footnotetext{
${ }^{339}$ In the view of the author EBITDA/sales represents a better proxy for profitability than EBITDA/ assets for LBOs because assets represent the purchase price at $t=0$. Therefore, EBITDA/assets would be the reciprocal of the EBITDA multiple of the enterprise value and highly negatively correlated with leverage, leading to multicollinearity problems. However, including EBITDA/assets does not change the results and profitability remains significant in all models.

${ }^{340}$ The market-to-book ratio is difficult to determine for non-public private equity transactions because (1) the book value before acquisition is not known and (2) even if it were known, the corporate structure changes significantly in a buyout disqualifying the historical book value of equity.

${ }^{341}$ Also, Billett/King/Mauer (2007) find a significant relationship for the growth proxy market-tobook, although they did not find any significant relationship for their sales growth proxies.
} 
This research design allows to draw direct conclusions regarding the potential shift of control rights, which are not in conflict with action-restricting covenants, but are complementary and might adhere to a different economic logic. Previous literature shows that high growth firms receive more action-restricting covenants; however, the analysis shows that they negotiate greater flexibility for their financial type covenants. Nevertheless, the significant influence of growth expectations on headroom could also have a mere technical reason in leveraged loan contract design, which can be explained by way of an example: a lead arranger analyzes two companies A and B, which are identical in each aspect except for their growth forecast, with A having higher growth prospects. The lead arranger calculates worst case scenario analyzes for both firms, which are consequently identical. Setting the covenant according to this analysis, both firms receive the same threshold. However, since the headroom expresses the distance between forecast and threshold, firm A automatically receives more headroom.

Interestingly, model 2 shows that the size of the target firm does not have a significant effect on financial covenant restrictiveness, while the base specification remains robust. One explanation for this result might be that lenders are more concerned with the reputation of the private equity sponsor than with the size of the target firm, implicitly transferring the sponsor related reputation to the borrowing firm. In line with this argument, removing the reputation variables from the equation does not alter the coefficients and t-values of the size variables. Anecdotal evidence supports this argument. Practitioners state that if KKR were to buy a significantly smaller than usual company they would still enjoy the favorable credit terms. The author could not test for this effect because there are only very few deals where a small company was acquired by a high reputation PE group and vice versa.

Model 3 tests whether the share of fixed to total assets has an impact on the decision of financial covenant restrictiveness. Interestingly, the analysis at best shows a negative effect of fixed to total assets on the D/EBITDA headroom. This result makes sense when taking into account that LBO loans constitute cash flow based lending, i.e. the 
shares are pledged, in contrast to collateral based lending, where the lenders have direct access to the collateral in case of default.

Model 4 includes business risk in the D/EBITDA headroom equation. There is no empirical relation between business risk and D/EBITDA headroom. One explanation for this finding might be that PE groups but also banks select targets which are expected to have a low volatility in cash flows and no further attention is devoted to this aspect in negotiations. A business which generated highly volatile operating cash flows is simply not a candidate for an LBO. This piece of evidence is supported when looking at the process of covenant construction which does not take into account any historical cash flow volatility. Implicitly, cash flow volatility might be taken into account when determining leverage levels. Nevertheless, the finding still seems puzzling as higher business risk should incentivize lenders to demand a shift in control early in order to reduce the potential for risk shifting.

\subsubsection{Transaction related}

In line with theoretical and empirical literature, the analysis shows that leverage, i.e. more financial risk, leads to more restrictive financial covenants, i.e. lower headroom - being robust for both D/EBITDA and D/EV measures for financial risk (see model 5 for the latter). Explicitly, increasing the D/EBITDA multiple by 1x reduces the leverage headroom by 70 basis points (a one standard deviation increase, i.e. 1.4x, results in a 134 basis points reduction in headroom).

Leverage, however, might be an endogenous variable in the equation, as it might not only affect financial covenant restrictiveness but also vice versa covenant restrictiveness might have an influence on leverage. ${ }^{342}$ While a detailed analysis of this potential problem is provided in the robustness section 6.5.3.4 below, the results will show that the models do not exhibit endogeneity, which is supported by characteristics regarding the process of headroom determination.

\footnotetext{
${ }^{342}$ For an entire study that discusses this issue see Billett/King/Mauer (2007).
} 
Model 6 tests the influence of interest costs in the form of all-in drawn spread on the D/EBITDA headroom. The result suggests that there is a negative (not significant) relationship between the all-in-drawn spread and D/EBITDA headroom. This means that higher interest costs are related to more restrictive covenants, i.e. lower headroom. This finding would principally contradict the agency theory of covenants as it predicts a tradeoff between interest costs and covenant restrictiveness, all else being equal.

However, a deeper analysis of the aggregation of the all-in drawn spread variable sheds light on this puzzling notion. As seen in section 6.4.3.2 the individual spreads show very little variation in the cross section and indicate a standardized pricing of debt tranches of leveraged loans in Europe. This implies that the overall interest cost, i.e. the all-in drawn spread, is primarily driven by the composition of the capital structure. For example, a higher share of subordinated debt with its higher spreads would mechanically increase the all-in drawn spread, given the same leverage level. Now, assuming that PE groups and lead arrangers achieve higher leverage levels by including more subordinated tranches in the debt structure implies that the all-in drawn spread is directly and solely driven by leverage levels. This explanation is supported by the reduction of t-value of the D/EBITDA variable, when including all-in drawn spread. The correlation between the all/in drawn spread and the D/EBITDA variable is 0.42 .

In terms of maturity, the data suggests that maturities for the tranches are standardized, i.e. there is only very little variation in the maturity of the different tranches. An analysis of weighted maturity yields identical results as the all-in-drawn spread because they are both merely driven by capital structure decisions. ${ }^{343}$ For brevity the analysis does not test for maturity as a determinant of financial covenant restrictiveness.

Model 7 includes the share of bank debt in the headroom equation. The share of bank debt is negatively (but not significantly) related to the D/EBITDA headroom. An explanation for this finding might be that bank debt does only increase the monitoring

\footnotetext{
${ }^{343}$ For a more detailed analysis of spread and maturity determinants see Achleitner/Braun/Tappeiner (2010).
} 
effort if it is held by the monitor, i.e. the lead arranging bank. However, bank debt in LBOs can be and are mostly syndicated to other banks reducing the incentive for the lead arranger to monitor. The final hold of the lead arranging bank seems to be a better proxy to measure the incentives for the lead arranger to monitor the loan and set covenants tighter.

Model 8 includes the creditor rights dilution index. It measures the number of clauses in the credit agreement that dilute the creditor rights in case of a covenant breach. The results in equation 8 suggest a positive and significant (at 5\% level) relationship between creditor rights dilution and D/EBITDA headroom. This seems to contradict the agency theory of covenants which predicts that creditor rights dilution and D/EBITDA headroom should be substitutes. As the clauses in the credit agreement and the D/EBITDA headroom are simultaneously determined and they are likely to influence each other, endogeneity might be a problem in the model. This will be tested in the robustness section.

\subsubsection{Sponsor related}

The analysis shows that PE group reputation, measured in terms of size (model 1-8, 12-16), lifetime (model 9), or number of deals (model 10), significantly increases D/EBITDA headroom. For example, an increase of assets under management by $€ 1$ billion or one standard deviation (approx. $€ 5$ billion) results in higher D/EBITDA headroom of 30 basis points or 128 basis points, respectively (at a mean of $23.2 \%$ headroom and a standard deviation representing 6.6 percent points headroom). Consequently, reputed private equity groups enjoy looser covenants in their deals.

The effect of reputation could be overstated if higher reputation PE groups have closer banking relationships to the lead arrangers which in turn affects the covenant restrictiveness by mitigating asymmetric information problems. Generally, reputable PE groups have done more deals historically they are more likely to have transacted with the lead arrangers of the respective LBO. Therefore, reputation might include a banking relationship component. To test this argument, model 11 includes the absolute number of historical deals (BR number (abs)) completed of the lead arranger and the 
respective PE group, while excluding PE group reputation. There is a significant positive relationship between BR number (abs) and D/EBITDA headroom. However, once PE group reputation is controlled for (model 12), BR number (abs) is unrelated to D/EBITDA headroom. This result is in line with DEMIROGLU/JAMES (2010b) who also show that PE groups generally tend to 'shop around for deal financing'. They give the example that Texas Pacific Group (TPG) borrowed from nine different lead banks to finance five deals between January 2006 and August 2007. The maximum number of deals a bank financed for TPG was two. ${ }^{344}$

This finding does not necessarily mean that PE groups that prioritize their bank relationships do not receive looser financial covenants. To test if PE groups that concentrate on specific bank relationships receive looser covenants the analysis includes the variable $B R$ volume, which measures the concentration of the PE group on a specific lead arranger, in model 13 (i.e. $B R$ volume divides the volume of sponsored loans of PE group A with lead bank B by the total volume of loans of PE group A). It shows that the effect is statistically not significant. The most likely interpretation of this finding is that PE group reputation dominates banking relationship which is in line with DEMIROGLU/JAMES (2010b) but in contradiction to IVASHINA/KOVNER (2010).

Practitioners support the reputational argument as they perceive reputation as a substitute for banking relationship. For example, a small bank would be willing to grant KKR very loose covenants even when it did not have any contact with KKR before. One might hypothesize that banking relationship is more important for low reputed PE groups. However, when testing for this relationship (not reported for brevity), the empirical analysis does not show evidence for this hypothesis.

The author also tests for the hypothesis that banking relationship might be more important for lower reputable PE groups. However, the analysis does not indicate that there is a relationship between the interaction term (low reputation/high banking relationship) and financial covenant restrictiveness.

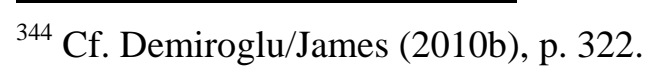




\subsubsection{Lead Arranger related}

Model 14 includes relative final hold in the D/EBITDA headroom equation. Although not significant and for a reduced sample of 79 observations, the model shows a negative relationship between the final hold of the lead arranger and the D/EBITDA headroom. Indicatively, lead arrangers seem more willing to accept less restrictive covenants when they hold less of the debt. However, as explained and hypothesized in 5.3.4.2, the final hold should have a more pronounced effect on the less easily observable clauses that dilute creditor rights than on the headroom which is a freely available signal to lenders. As creditor rights and financial covenants are determined simultaneously and might face reverse causality, this analysis is part of the robustness section 6.5.3.3.

\subsubsection{Macroeconomic related}

All models include credit market conditions in the form of credit spread between AAA and BB bonds. The analysis shows - while not statistically significant at conventional levels - that credit spread is negatively related to the D/EBITDA headroom. This finding is again intuitive: the higher the credit spread, i.e. the higher the risk awareness of the credit market, the lower the D/EBITDA headroom. This is in line with the findings of AXELSON et al. (2010) and DEMIROGLU/JAMES (2010b) that LBO activity and transaction terms are related to the overall credit environment. This is a further piece of evidence in the boom and bust pattern of the LBO market.

\subsubsection{Robustness}

\subsubsection{Fixed Effects}

One caveat of the results might be that they are based on industry specific effects on the dependent variable D/EBITDA headroom. To test this, the pooled OLS regression shown in model 16 accounts for industry and time fixed effects. The standard errors are clustered by industry and deal year, a method also used by AXELSON et al. (2010). ${ }^{345}$ It shows that the results are robust to the inclusion of such effects. Addition-

\footnotetext{
${ }^{345}$ Cf. Axelson, et al. (2010), p. 28.
} 
ally, PE groups might define D/EBITDA differently and therefore lead to measurement error of the D/EBITDA headroom. When including PE group fixed effects, the PE group size effect disappears, which seems intuitive because of the relatively homogenous distribution of the size of the same PE group. Other results remain robust. Another caveat might be that banks have their own definitions of the D/EBITDA covenant. ${ }^{346}$ Given that the average deal in the sample was arranged by 1.96 lead arranging banks, the entire sample including 23 different lead arranging banks, the sample does not include sufficient observations to include bank fixed effects. An argument against bank and LBO fixed effects is that the dataset shows that headroom definitions differ from deal to deal and are not standardized neither for LBO firms nor lead arranging banks.

\subsubsection{EBITDA Definition}

Besides the outlined advantages of the headroom as a measure of covenant restrictiveness, the headroom might also be exposed to the same measurement error as the slack in the cross-section due to varying definitions of the D/EBITDA ratio across LBOs. As fixed effects for the PE group and/or lead arranging bank cannot solve this problem because each deal contains its own unique definition of the input variables of financial covenants, it is essential to test the results when including a variable that captures the restrictiveness of the definitions. In order to address this potential issue, this section constructs a measure capturing the restrictiveness of the EBITDA definition in the LBO credit agreements and includes the variable in the regression analysis.

Being well aware of the low comparability of the definitions of loans in general and leveraged loans in particular, the Loan Market Association (LMA) tries to standardize definitions used to calculate financial covenants in credit agreements. As Mark Campbell, Head of Global Finance of Clifford Chance put it:

${ }^{346}$ Cf. Ivashina/Kovner (2010), p. 35. 
'... LMA covenants [definitions] define exactly what EBITDA is for the purposes of the document ... ' 347

While the final definitions in the individual credit agreements may differ from the LMA standard, LMA definitions are typically used as a starting point to negotiate the definitions of covenants. Over the course of the deal process, definitions are possibly customized, depending on the negotiation between lead arranger and sponsor.

To control for the effect of definitions, the author captures the deviation of the deal specific EBITDA definition to the standardized LMA definition for EBITDA in leveraged loans. Specifically, the author counts the number of add-backs to net income to arrive at EBITDA. If the credit agreement contains less add-backs than the LMA standard the dummy variable Strict EBITDA Definition is set to 1 . If the credit agreement contains more add-backs than the LMA standard the dummy variable Loose EBITDA Definition is set to $1 .{ }^{348}$

\subsubsection{Endogeneity of Headroom and Creditor Rights Dilution}

Besides the financial covenant restrictiveness, the effectiveness of financial covenants is essential to execute control in case of a financial covenant violation. However, the functioning of covenants may be deterred if loan agreements contain clauses which alleviate the primary purpose to transfer control rights from borrowers to lenders in the case of a covenant breach. In these cases covenant enforcement is limited. ${ }^{349}$

In addition, the utility of a marginal unit of looser covenants, e.g. $1 \%$ more headroom, is declining with loosening covenants. ${ }^{350} \mathrm{PE}$ groups might not push for a further loosening in covenants beyond a certain level of headroom. At this point PE groups might attribute higher value to limit the effect of a covenant breach as opposed to an addi-

\footnotetext{
${ }^{347}$ Cf. Clifford Chance (2007), p. 4.

${ }^{348}$ EBITDA being the most important item in financial covenant calculations is also a good proxy for other relevant covenant inputs, like e.g. debt.

${ }^{349}$ See section 4.3.4 for the effectiveness of financial covenants and see section 6.4.3.2 for a description of the operationalization of the clauses that dilute creditor rights.

${ }^{350}$ The results of the cross-sectional analysis are robust against the inclusion of a logged D/EBITDA headroom as dependent variable.
} 
tional unit of looser headroom. In the context of process, covenant headrooms and creditor rights are simultaneously negotiated between PE groups and banks, i.e. they are jointly determined. Both are observable variables for the latent construct of lender control. The equations for D/EBITDA headroom and creditor rights are autonomous, i.e. they have their own economic interpretation, meaning that they have a ceteris paribus, causal interpretation. Consequently, simultaneous equation models might solve the problem of endogeneity. ${ }^{351}$ Table 31 shows the results for the first stage regression (model 1,2) with D/EBITDA headroom as the dependent variable and the second stage regression (model 3,4) with creditor rights dilution as the dependent variable.

In contrast to the observed positive relationship in the simple OLS of Table 29, model 3 shows a negative but not significant relationship between instrumented D/EBITDA headroom and creditor rights dilution. The considerable difference of the OLS and IV estimates is strong evidence that covenant headroom and creditor rights dilution are endogenous. Conducting a Durbin Wu Hausman test for endogeneity leads to a strong rejection of the null hypothesis $(\mathrm{F}=12.05 ; \mathrm{p}=0.0007)$ that headroom is exogenous in the creditor rights dilution equation. Therefore, one concludes that it is endogenous. ${ }^{352}$

The regressions also show that reputation not only leads to more headroom but also significantly increases creditor rights dilution. In the context of lender control it seems that reputable sponsors can attenuate the trade-off between favorable (i.e. less restrictive) financial covenants and favorable clauses (i.e. diluting the creditor's control).

To test hypothesis 13, model 2 and 4 include relative final hold of the lead arranger. It shows that the lead arranger's final hold is significantly positively related to the creditor rights dilution. This means that the more a lead arranger plans to syndicate the more clauses he is willing to accept in the credit agreement. However, one could argue that the causal relationship is the other way round, i.e. more creditor rights dilution leads to a lower final hold. But, given that the final hold is typically determined at the

\footnotetext{
${ }^{351}$ Cf. Wooldridge (2002), p. 209f., Wooldridge (2006), p. 552f.

${ }^{352}$ If the relationship changes to the opposite direction in a two stage regression this is a good indication for a simultaneous equation. Cf. Cameron/Trivedi (2009), p. $189 f$.
} 
beginning of the negotiations and creditor rights dilution at the end, it seems likely that the final hold impacts the clauses.

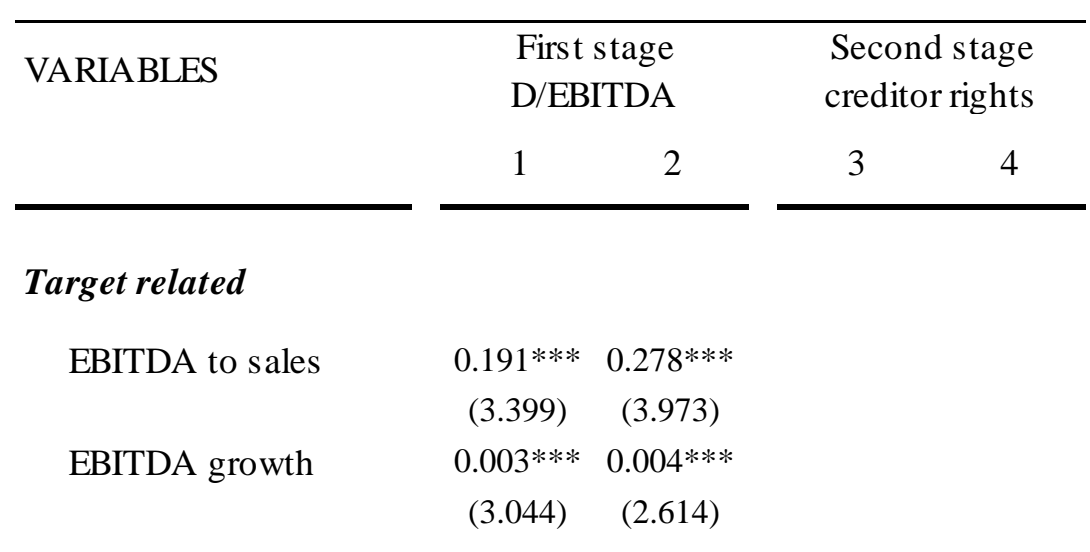

Transaction related
D/EBITDA
$-0.007 * * \quad-0.014 * * *$
$(-2.223) \quad(-2.863)$

D/EBITDA headroom

$$
\begin{array}{cc}
-8.365 & -4.778 \\
(-1.489) & (-1.043)
\end{array}
$$

\section{Sponsor related}

$$
\begin{array}{lcccc}
\text { PE group size } & 0.003^{* *} & 0.003^{* *} & 0.124^{* * *} & 0.080^{* *} \\
& (2.204) & (2.100) & (4.027) & (2.369)
\end{array}
$$

\section{Lead arranger related}

Relative final hold

$$
\begin{array}{cc}
-0.043 & -1.982 * * * \\
(-1.435) & (-3.509)
\end{array}
$$

\section{Macroeconomic related}

\begin{tabular}{lcccc}
\multicolumn{1}{l}{ Credit spread } & -0.002 & -0.004 & -0.079 & $-0.268^{* * *}$ \\
& $(-0.701)$ & $(-1.125)$ & $(-0.949)$ & $(-3.331)$ \\
& & & & \\
Constant & $0.204^{* * *}$ & $0.222^{* * *}$ & $3.095^{* *}$ & $3.786^{* * *}$ \\
& $(9.965)$ & $(7.394)$ & $(2.350)$ & $(3.525)$ \\
& & & & \\
Observations & 126 & 126 & 79 & 79 \\
R-squared & 0.169 & -0.088 & 0.273 & 0.241 \\
& & & & \\
\hline t-statistics in parentheses & & & & \\
*** $<<0.01, * * \mathrm{p}<0.05, * \mathrm{p}<0.1$ &
\end{tabular}

Table 31: Endogeneity of D/EBITDA headroom and creditor rights dilution 
Source: $\quad$ LBO dataset

\subsubsection{Endogeneity of Leverage and Financial Covenants}

Many scholars suspect and find evidence for simultaneous causality between leverage and covenant restrictiveness. ${ }^{353}$ Their analysis focuses on the mere existence of covenants and not on the inherent restrictiveness of financial covenants. Negotiations on the leverage in LBOs take place at the beginning of the loan arrangements (mostly at the proposal stage), while the restrictiveness of financial covenants (i.e. headroom) is negotiated during the final phase of the loan arrangement. ${ }^{354}$ Hence, conceptually expect no problem of endogeneity, i.e. that the level of headroom has a causal effect on the level of leverage in the models of financial covenant restrictiveness.

Nonetheless, in order to test for these effects the author conducts Wu-Hausman tests. The all-in-drawn spread is used as instrument for the suspected endogenous leverage variable: like leverage, all-in-drawn spread, defined as the value-weighted sum of the spreads over EURIBOR of the utilized senior and subordinated tranches, is a parameter of the credit contract that is set at the beginning of the loan negotiations and should be exogenous to the financial covenant models for several reasons: First, the pricing of the different tranches in leveraged loans is mostly driven by credit markets and therefore experiences very low variations as also noted for buyouts in the 1980ies by KAPLAN/STEIN (1993). Second, standardized spreads are characteristic for European credit markets, in contrast to spreads in the US that are negotiated to be more flexible as indicated by DEMIROGLU/JAMES (2010b) and IVASHINA/KOVNER (2010). Finally, the interviews with lead arrangers and sponsors support the assumption that there is no link between spreads and financial covenant restrictiveness.

Further, all-in-drawn spread as defined above, is a relevant variable, as leverage and all-in-drawn spread are strongly correlated (correlation coefficient: 0.44). This relationship is mechanical as more expensive subordinated debt is used in more highly

\footnotetext{
${ }^{353}$ See e.g. Bradley/Roberts (2004) or Billett/King/Mauer (2007).

${ }^{354}$ For further details see Ivashina/Kovner (2010).
} 
leveraged transactions. ${ }^{355}$ Regressing leverage on all-in-drawn spread results in a highly significant coefficient (t-value of 5.36, i.e. a p-value of 0.00). The Wu-Hausman tests indicate no relevant endogeneity in the models, since the residuals from the reduced form regression on leverage have no significant impact on headrooms in the initial structural form.

\subsubsection{Accounting Manipulation}

An additional concern might be the adequateness of the measure for covenant restrictiveness. According to DICHEV/SKINNER (2002), borrowers might engage in accounting manipulation to avoid financial covenant violation. This behavior might reduce the effectiveness of financial covenants overall and thus the importance of their restrictiveness.

However, several reasons argue against a substantial accounting manipulation in loan agreements in general and syndicated loans in particular. First, lead arrangers have considerable experience in originating and monitoring loans, reducing the ability of borrowers to 'consistently fool private lenders via accounting manipulation'. 356

Second, lead arrangers define financial covenants in great detail and the calculations are specified ex-ante and implemented in the financial models. ${ }^{357}$ These financial models are then used to monitor the borrower and there is little room for unobservable manipulation of covenant calculation. And in case of observable manipulation the borrower risks a default due to the material adverse change clause. ${ }^{358}$

Third, credit agreements constitute a freeze of the applied accounting standard, which does not allow any changes in the specified accounting principles during the duration of the loan. ${ }^{359}$

\footnotetext{
${ }^{355}$ Cf. also Achleitner/Braun/Tappeiner (2010).

${ }^{356}$ Cf. Chava/Roberts (2008), p. $2106 f$.

${ }^{357}$ For definition guidelines, see the loan market association. In practice, definitions are individually negotiated and can become quite complex.

${ }^{358}$ Cf. Eilers/Koffka/Mackensen (2009), p. 324.

${ }^{359}$ Cf. Tirole (2006), p.87f.
} 
Fourth, the quarterly calculation of financial covenants during the lifetime of the loan has to be certified by auditors and the chief financial officer of the firm. This ensures that an illegal manipulation may lead to litigation. Finally, empirical evidence suggests that managers prefer to cut investments over accounting manipulation in order to prevent covenant violations. ${ }^{360}$ While this last argument does not rule out accounting manipulation it shows that accounting manipulation is a measure of last resort for management to prevent covenant violation. But given the other arguments it is likely that most of the efforts to circumvent covenant breaches will be detected by lenders, unless they have criminal intent, which is unlikely to be prevented by contractual measures.

\subsubsection{Analysis on Pecking Order of Financial Covenants}

In section 6.4.2 the structure of financial covenants indicated that there is a specific hierarchy in the setting of covenants, i.e. the D/EBITDA covenant is set to breach first and the CashFlowCoverage is set as a covenant of last resort. As the CashFlowCoverage threshold is typically set to 1 , the respective headroom is merely a proxy for financial risk of the transaction. Consequently, one would expect that the headroom is primarily driven by variables that directly drive financial risk of the transaction, like leverage, spread, maturities, repayment schedules and also the macro credit environment. This interaction is not the case for the D/EBITDA headroom.

The role of PE group reputation is ambiguous. On the one hand, higher reputation should lead to looser financial covenants, i.e. more headroom. On the other hand more headroom in terms of the CashFlowCoverage covenant means lower financial risk. However, given the incentive structures of PE funds, GPs generally strive to maximize financial risk. This means that high Cash FlowCoverage headroom indicates potential to increase financial risk, i.e. the transaction could be financed with more leverage.

To test these expectations, the analysis starts with the same basic specification as for the D/EBITDA covenant headroom (see Table 32 model 1). It shows that, as expected,

\footnotetext{
${ }^{360}$ Cf. Graham/Harveya/Rajgopalc (2005) and Chava/Roberts (2008). While cutting investment does not improve financial covenants directly, the cash preserved by not undertaking investments is considered in the net debt calculation (Net debt $=$ Debt - Cash).
} 
the D/EBITDA multiple is significantly and negatively related to the CashFlowCoverage headroom. Intuitively, since the CashFlowCoverage threshold is typically set to 1, a higher D/EBITDA multiple leads to a higher debt service reducing the headroom mechanically. This effect is robust in all specifications.

The base specification (model 1) also reports that the general credit market environment is a significant determinant (at the $5 \%$ level) of the CashFlowCoverage headroom. If the risk aversion in the credit market increases, proxied by an increase in the credit spread between AAA and BB bonds, the CashFlowCoverage headroom decreases. This means in risk averse credit markets, lenders prefer less risky leverage loans, where the distance between the forecasted unlevered cash flow and the required debt service is larger. This effect is robust for all tested specifications.

PE group size does not have a significant effect on the CashFlowCoverage headroom, supporting the ambiguous expectation stated above. When including additional control variables, the coefficients as well as the t-values of PE group reputation decrease continuously.

Specification 2 includes the weighted spread in the equation. One would expect that a higher interest burden would decrease the CashFlowCoverage headroom as it increases the debt service, which a direct input for the calculation for the CashFlowCoverage ratio. Paradoxically, model 2 shows that there is a significant positive relationship between the weighted spread and the CashFlowCoverage headroom. This would imply that a higher weighted spread leads to an increase in the CashFlowCoverage headroom. One explanation for this could be that a higher weighted spread is also driven by a higher share of subordinated debt, which does not have any repayments over the first years of the transaction and also includes a PIK payment, both elements reducing the debt service. Indeed, when including the share of subordinated debt in model 3, the effect of weighted spread is reduced to statistical insignificance.

A further determinant of the CashFlowCoverage headroom might be the share of the Term A loan, as this tranche is the only amortizing tranche during the first years of the transaction. One would expect that a higher share of Term A loans increases the debt 
service and consequently reduces the CashFlowCoverage headroom, all else being equal. Model 4 includes the share of Term A and finds that a higher share of Term A loan leads to significantly lower CashFlowCoverage headroom.

These results support the notion, that the CashFlowCoverage headroom is a mere proxy for financial risk as it is mechanically determined by factors contributing to financial risk. Consequently, the CashFlowCoverage headroom is not an unambiguous proxy for financial covenant restrictiveness and the analysis supports the pecking order argument of financial covenants. 


\begin{tabular}{llllll}
\hline VARIABLES & 1 & 2 & 3 & 4 \\
\hline
\end{tabular}

\section{Target related}

$\begin{array}{lcccc}\text { EBITDA to sales } & 0.220 & 0.235^{*} & 0.235^{*} & 0.272 * \\ & (1.583) & (1.759) & (1.746) & (1.975) \\ \text { EBITDA growth } & 0.001 & 0.001 & 0.001 & 0.001 \\ & (0.559) & (0.513) & (0.511) & (0.615)\end{array}$

\section{Transaction related}

$\begin{array}{lcccc}\text { D/EBITDA } & -0.018^{* * *} & -0.023^{* * *} & -0.023^{* * *} & -0.026^{* * *} \\ & (-3.213) & (-3.610) & (-3.600) & (-4.070) \\ \text { Weighted spread } & & 0.021^{* *} & 0.020 & \\ & & (1.991) & (0.688) & \\ \text { Share of subordinated debt } & & & 0.016 & \\ & & & (0.041) & \\ \text { Share of Term A loan } & & & -0.210^{* *} \\ & & & (-2.450) \\ \text { Sponsor related } & & & \\ \text { PE group size } & & & \\ & & & \\ & & & & 0.001 \\ \end{array}$

\section{Macroeconomic related}

Credit spread

Constant

Observations

R-squared

$$
-0.011^{* *}
$$

$0.315^{* * *}$

(7.995)

126
0.110

$-0.014^{* *}$

$(-2.110)$

$-0.014 * *$ $-0.011^{* *}$

$(-2.093)$

$(-2.108)$

$0.271^{* * *}$

$0.273^{* * *}$

$0.398^{* * *}$

(6.111)

(3.715)

(7.720)

125
0.138

125

126

0.138

0.154

t-statistics in parentheses

*** $\mathrm{p}<0.01,{ }^{* *} \mathrm{p}<0.05,{ }^{*} \mathrm{p}<0.1$

Table 32: Determinants of the CashFlowCoverage headroom

Source: LBO dataset 


\subsection{Summary of Hypotheses Testing}

To consolidate the findings about the determinants of financial covenant restrictiveness, Table 33 reports the acceptance or rejection of the hypotheses based on the empirical analysis of the proprietary LBO dataset.

With regard to target related determinants, the empirical tests show strong evidence that the growth of the target firm leads to less restrictive financial covenants. Interestingly, this finding contradicts the predictions of the agency theory of covenants. It would predict that high growth firms are exposed to higher risk of underinvestment and, therefore, receive more restrictive covenants. This study shows that the prediction does not hold for the tightness of financial covenants but that growth leads to looser financial covenants. This finding is a strong indication that high growth firms attribute a higher value to flexibility in comparison to low growth firms and, hence, opt for looser financial covenants. Besides the statistical significance, the expected growth of the firm also has an economically important effect on financial covenants. A one standard deviation increase in expected EBITDA growth increases the headroom by 173 bps (at the mean of $23.2 \%$ headroom).

Another target related factor that seems to have an impact on the financial covenant restrictiveness is the profitability of the target firm. In line with implications of agency control rights theory, more profitable firms seem to enjoy looser financial covenants, because lenders assess realized profitability as a signal for future performance of the firm. The effect of profitability is also economically important increasing the headroom by 187 bps for a one standard deviation increase of EBITDA/sales.

With regard to transaction related factors that are hypothesized to have an impact on financial covenant restrictiveness, especially leverage, either in terms of D/EBITDA or $\mathrm{D} / \mathrm{EV}$, seem to have an influence. In line with agency theoretic implications, more debt increases the incentives for risk shifting actions, lenders demand tighter financial covenants when leverage levels are higher. This is also in line with existing empirical evidence. Economically, a one standard deviation increase in leverage reduces the D/EBITDA headroom by 134 bps. 


\section{Hypotheses on the Restrictiveness of Financial Covenants}

\section{Expected influence $\quad$ Empircal result}

Target related

$\mathrm{H} 1 \quad$ Size

H2a/b Growth

H3 Profitability

$\mathrm{H} 4 \mathrm{a} / \mathrm{b}$ Operating risk

H5 Tangibility

$$
\begin{gathered}
\text { a: +/b: - } \\
- \\
\text { a: +/b: - }
\end{gathered}
$$
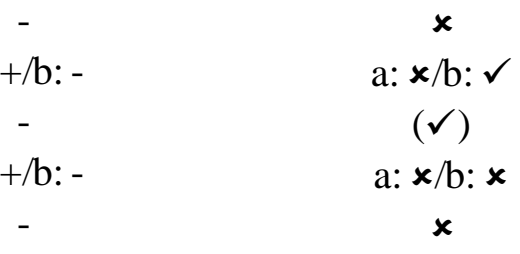

\section{Transaction related}

H6 Leverage

H7 Interest cost

H8 Maturity

H9a/b Share of bank debt

H10 Creditor rights dilution

\section{Sponsor related}

H11 Sponsor reputation

H12a/b Banking relationship

\section{Lead arranger related}

H13 Final hold

\section{Macroeconomic}

H14 Credit spread

$$
\text { a: -/b: - }
$$

a: $\mathbf{x} / \mathrm{b}: \mathbf{x}$

+ Hypothesized positive relationship between the potential determinant and covenant restrictiveness

- Hypothesized negative relationship between the potential determinant and covenant restrictiveness

$\checkmark$ denotes that based on empirical results hypothesis should not be rejected

$(\checkmark)$ denotes that based on empirical results hypothesis should not be rejected - weaker statistical evidence

$\boldsymbol{x}$ denotes that based on empirical results hypothesis should be rejected

Table 33: $\quad$ Summary of hypothesis testing

Source: Author

In the category of sponsor related, i.e. private equity group related, hypotheses the empirical evidence suggests that the reputation of the private equity group alleviates risk shifting incentives which implies looser financial covenants. This finding is the first empirical evidence supporting theoretical implications for the restrictiveness of finan- 
cial covenants. It is particularly interesting as it contributes to the uncovering of the persistence phenomenon of top performing private equity groups. ${ }^{361}$ Not only do high reputation private equity groups receive more debt to acquire companies and enjoy lower interest costs as shown by DEMIROGLU/JAMES (2010b), they also receive looser financial covenants. An increase of assets under management, as a proxy for private equity group reputation, by $€ 1$ billion results in a significantly higher D/EBITDA headroom of 30 bps.

This study does not find supporting evidence for the results of IVASHINA/KOVNER (2010) on the effect of banking relationship between the sponsoring private equity group and the lead arranging bank on financial covenants. It seems that reputational and banking relationship arguments are not additive. This in turn is in line with DEMIROGLU/JAMES (2010b) who also show that private equity groups generally tend to 'shop around for deal financing', which is an indication that banking relationships are not very valuable in the leveraged loan market.

In terms of lead arranger related hypotheses, the study does not document a significant impact of the final hold on covenant restrictiveness. One explanation might be the low number of observations for the final hold. Another explanation is that financial covenants serve as guard posts in the relationship between arranger and participant, while less transparent agreements are set between arranger and sponsor to the detriment of the syndicate participants. This study confirms a significant negative relationship between the final hold and less transparent clauses that dilute creditor rights. However, this finding is again subject to the caveat of the reduced sample of 79 observations.

\subsection{Limitations of the Analysis}

This section discusses the limitations of the study. One obvious point of critique is the sample bias. First, the characteristics of the sponsored and non-sponsored loans might deviate in a way which does not allow a benchmarking of the financial covenant structure. One obvious concern is that the sponsored loans are originated in Germany whereas the non-sponsored loans have a large focus on the US, given the data availa-

${ }^{361}$ Cf. Kaplan/Schoar (2005). 
bility in Dealscan. The benchmarking might lead to wrong conclusions if nonsponsored loans in the US contain fundamentally different covenant structures in comparison to German non-sponsored loans.

Second, and related to the first concern, the transferability of the results regarding the restrictiveness of financial covenants to other jurisdictions might be difficult if Germany is not a representative institutional setting to analyze financial covenants. Given the strong creditor rights and the associated relatively higher importance of financial covenants might lead to conclusions, which are correct for Germany but may be incorrect for countries with weaker creditor rights, like e.g. the US. For example, covenantlite deals were very common in the US, while they were very seldom in Europe, indicating that covenants are less important in the US. However, although this argument is valid, the author thinks that while the institutional setting is a considerable driver itself, there is no reason why the identified drivers in this study are not generally applicable to other institutional settings.

Regarding the representativeness of the sample for the German market, the sample covers roughly $40 \%$ of the transaction volume (excluding recapitalizations) from 2000 to 2008. However, the sample covers deals from three lead arrangers that might select deals with certain characteristics, leading to a selection bias. Nevertheless, comparing the sample across different characteristics (exit types, leverage levels etc.) to available German and Western European benchmarks does not reveal any fundamental bias.

Another point of critique might be that the banks only disclosed their more successful loans. While this is an argument that cannot be entirely ruled out, an argument that alleviates the concern is that the dataset contains many loans which were in default even before the data collection process started, indicating that banks did not filter transactions in advance.

Furthermore, banks could have specific lending practices, which are not addressed in the analysis. To circumvent this effect one would have to control for bank fixed effects. Given that the sample includes 23 lead arranging banks, and the average deal was arranged by 1.96 lead arrangers, a bank specific effect is hard to estimate. 
Finally, the measurement error of the restrictiveness measure, i.e. the D/EBITDA headroom, might lead to endogeneity problems. If the inputs of the D/EBITDA headroom are defined differently from deal to deal, a cross-sectional comparison might introduce measurement error in the equations as independent variables might correlate with the error term in the regression. However, as discussed in section 4.3.3 the headroom seems to be the measure for restrictiveness with the lowest potential for measurement error. Additionally, when testing the results with variables that control for different covenant definition results remain robust. 


\section{Conclusion}

\subsection{Summary of Results}

Private equity investors are important providers of capital for companies. Still, we know relatively little about the detailed financial structure of LBOs. ${ }^{362}$ This thesis is the first academic attempt to provide a detailed view on financial covenants in LBOs, by answering the following two primary research questions:

- How does the covenant menu in terms of individual covenant types and combinations differ in sponsored in comparison to non-sponsored loans?

- What are the determinants of financial covenant restrictiveness in LBOs?

In order to address these research questions, the thesis builds a theoretical framework explaining the economic rationale of covenants in general and financial covenants in particular. Different types of action-restricting and financial covenants are presented and their existence explained by applying the theoretical framework. The thesis further uses existing literature to discuss and formulate expectations regarding the differences in the covenant structure of public, private (non-sponsored) and LBO (sponsored) loans. Then, theoretical arguments as well as empirical findings are combined to formulate hypotheses on potential determinants of financial covenant restrictiveness. As the empirical part of the thesis is the main academic contribution, the dataset and findings will be explained in greater detail.

To test the expectations and hypotheses the author constructs a proprietary LBO dataset including sponsored loans and two benchmark datasets consisting of traditional corporate loans, i.e. non-sponsored loans. The proprietary LBO dataset consists of 130 German LBO transactions from 2000 until 2008 which covers approximately $40 \%$ of the German LBO market. Germany represents a fruitful institutional setting to understand covenants since it is an economy with strong creditor rights ${ }^{363}$ where covenants

\footnotetext{
${ }^{362}$ Cf. Axelson, et al. (2010).

${ }^{363}$ Cf. La Porta, et al. (1997), Djankov/McLiesh/Shleifer (2007).
} 
can be directly enforced in case of a default ${ }^{364}$ and, hence, are subject to rigorous exante negotiations. The LBO dataset includes detailed covenant information from the credit agreements and financial forecasts for the portfolio companies negotiated between the banks and private equity sponsors. The sample comprehends 23 lead arrangers and 66 private equity sponsors, which largely operate on an international basis. To the best knowledge of the author there are no fundamental reasons why the findings based on this sample cannot be extended to other countries. The benchmark datasets consist of non-sponsored loans with covenant information from Dealscan.

Before explaining the results for the first research question it is essential to understand why one would expect any difference in the structure of financial covenants in sponsored versus non-sponsored loans. On the one hand, more frequent and larger in scale interactions of private equity investors with the lending market should reduce information asymmetry costs, which in turn lead to less restrictive covenant structures for sponsored loans. But on the other hand, higher financial risk due to increased leverage levels of LBOs should lead to more restrictive covenant structures for sponsored loans.

In terms of results, the thesis compares the covenant menu of sponsored and nonsponsored loans in terms of the following seven covenant types, highlighted by researchers and practitioners: (1) debt to EBITDA (D/EBITDA), (2) EBITDA to interest (EBITDA/I), (3) unlevered cash flow to debt service (CashFlowCoverage), (4) Capex, (5) Net Worth, (6) debt to equity (D/E) and (7) Current Ratio covenants.

The comparison of the samples shows that covenant structures in non-sponsored loans are less standardized than in sponsored loans. With regards to the individual use of covenants, sponsored loans only contain the first four covenants while non-sponsored loans include all seven types of financial covenants. Concerning the combinations of covenants, the most frequent combination in sponsored loans - which contains D/EBITDA, EBITDA/I, CashFlowCoverage and Capex covenants - is found in 67.9\% of the sponsored sample. By contrast, the most frequent combination in non-sponsored loans - which comprehends D/EBITDA and EBITDA/I covenants - is encountered in

${ }^{364}$ Cf. Lerner/Stromberg/Sorensen (2009). 
only $13.3 \%$ of the sponsored sample. In line with this observation, sponsored loans restrict more financial ratios (3.6) than non-sponsored loans (2.8).

Why is this the case? One intuitive explanation is that the increased financial risk argument may outweigh the reduced information asymmetry costs argument. The author examines this conjecture by comparing the sponsored loans with a subsample of nonsponsored loans where the borrowers have similar financial risk. Surprisingly, the results remain virtually unchanged: Sponsored loans still include more covenants (3.6) than non-sponsored loans (2.8) when controlling for financial risk. This result is robust to several alternative benchmark samples.

The second explanation might be that sponsored loans contain more covenants but they may be less restrictive. The author tries to examine this conjecture by investigating covenant thresholds, the restrictiveness proxy available for the benchmark sample. The results show that the covenant thresholds are mechanically driven by financial risk. Hence, thresholds represent only a precise restrictiveness measure when they are set in relation to the expected financial ratio. This is methodologically challenging for public companies as the definition of the input variables for the covenant calculation are likely to deviate from the publicly available forecasts of equity research. Additionally, the consolidation in the credit agreement might be different in the credit agreement in comparison to the available financial statements. This poses great difficulties for the analysis, as already stated by IVASHINA/KOVNER (2010) and is not part of this thesis. $^{365}$

However, in order to answer the second question, what are the determinants of financial covenant restrictiveness in LBOs, the proprietary LBO dataset allows for the exact comparison of the threshold with the corresponding expected financial ratio. The thesis investigates the effects of target, transaction, sponsor, lead arranger and macroeconomic related factors on the D/EBITDA covenant headroom. The headroom represents the negotiated percentage deviation between the lead arranging bank and the private

\footnotetext{
${ }^{365}$ For further details, please see section 3.2.1.
} 
equity investor that the limited financial ratio is allowed to deteriorate from the expected ratio before the covenant is violated.

The detailed descriptive analysis of the D/EBITDA, EBITDA/I and CashFlowCoverage unveil that thresholds move monotonically with financial risk over the forecasted years and that headrooms increase, i.e. become looser, with decreasing financial risk. Additionally, the pattern of the time series analysis support the boom and bust cycle of the private equity industry, financial covenants being looser in boom and tighter in credit crises.

An interesting finding in the data is that there exists a financial covenant pecking order. Particularly during the first two years where the financial risk is the highest, the D/EBITDA covenant is the most important financial covenant. Therefore, the D/EBITDA headroom is the crucial determinant of the restrictiveness of financial covenants and therefore heavily negotiated between sponsors and lead arrangers. Consequently, the D/EBITDA headroom during the first two years after loan origination is the primary measure for covenant restrictiveness and serves as the primary dependent variable in the empirical analysis of financial covenant restrictiveness. The CashFlowCoverage covenant is typically set to 1 in LBO credit agreements supporting the notion that it serves as the financial covenant of last resort.

In the cross-sectional analysis, the study finds empirical evidence that high growth opportunities decrease the restrictiveness of financial covenants. This finding supports the argument that high-growth companies assign more value to flexibility than lowgrowth firms. Increasing the expected EBITDA growth forecast over the first three years after the buyout by one percentage point or one standard deviation increases the D/EBITDA headroom by 30 bps or 173 bps, respectively.

Regarding profitability, the analysis suggests that more profitable firms receive looser financial covenants. Hence, lenders seem to exert less control and grant more flexibility to borrowers whose performance signals historically 'good' behavior. An increase in the EBITDA margin by one percentage point or one standard deviation (9.7 percentage points), increases the leverage headroom by about 19 basis points or 187 basis 
points, respectively. Interestingly, the analysis does not find empirical support for the hypothesis that company size is related to financial covenant restrictiveness. Apparently, the syndicated loan market seems to confer the reputation of the sponsor on the borrower.

In line with agency theoretic implications, more financial risk increases the incentives for risk shifting actions inducing lenders to demand tighter financial covenants. The study documents that a higher leverage at entry (measured in terms of D/EBITDA or $\mathrm{D} / \mathrm{EV}$ ) reduces the D/EBITDA headroom significantly, i.e. tightens financial covenants. Economically, a one standard deviation increase in D/EBITDA reduces the D/EBITDA headroom by 134 bps.

Besides this covenant tightening of increased financial risk in LBOs, the reputation of the private equity groups alleviates risk shifting incentives leading to looser financial covenants. This is particularly interesting as it contributes to the uncovering of the persistence phenomenon of top performing private equity groups. ${ }^{366}$ Not only do high reputation private equity groups receive more debt to acquire companies and enjoy lower interest costs as shown, they also receive looser financial covenants. An increase of assets under management, as a proxy for reputation and historical success, by $€ 1$ billion or one standard deviation (approx. $€ 5$ billion) results in higher D/EBITDA headroom of 30 bps or 128 bps, respectively.

An interesting byproduct of the robustness analysis of the results is that the financial covenant restrictiveness is traded-off against the effectiveness of financial covenants. This means, assuming a constant cost of debt, borrowers derive a higher utility by including clauses in the credit agreement that dilute the creditor rights in case of covenant breach than further loosening covenant restrictiveness. Specifically, they exchange a certain increase of D/EBITDA headroom with an additional clause, like e.g. an equity cure right. Another important driver of clauses diluting creditor rights is the

${ }^{366}$ Cf. Kaplan/Schoar (2005). 
final hold of the lead arranger, which might indicate a moral hazard problem in the relationship between lead arrangers and participants. ${ }^{367}$

\subsection{Implications for Research}

The findings of this study contribute to both, the LBO literature and the covenant literature. In terms of the LBO literature, covenants as non-price credit terms have received only very little attention until now due to the limited data availability and quality. Only recently, two notable contributions have helped to shed light on these essential components of the debt package. IVASHINA/KOVNER (2010) examine the effect of private equity investors' bank relationships on the covenant threshold for their portfolio companies. In a related paper, DEMIROGLU/JAMES (2010b) focus on the effect of private equity investors' reputation on the number of financial covenants for private equity portfolio companies.

This study contributes to these valuable insights on covenants in LBOs in the following ways: (1) it provides a detailed picture of the financial covenant menu in terms of types and combinations relative to a benchmark of non-sponsored loans, (2) it provides a detailed insight into the institutional covenant setting process and precisely calculates covenant restrictiveness measures based on the proprietary LBO data ${ }^{368}$, (3) it complements and extends the results of IVASHINA/KOVNER (2010) and DEMIROGLU/JAMES (2010b) on target, transaction and especially sponsor related arguments. In addition, (4) it looks at a further so far unnoticed element in credit agreements, clauses that dilute creditor rights. These clauses are heavily negotiated between private equity groups and banks, which are an important element of the cost of debt.

This study is also related to AXELSON et al. (2010) and KAPLAN/STEIN (1993) who show that (1) the amount, repayment schedules and tranche partitions of debt and (2) buyout pricing are driven by market wide conditions of debt. These results suggest

\footnotetext{
${ }^{367}$ This finding is only indicative due to a reduced sample size.

${ }^{368}$ The author was able to receive the credit documentation and the financial forecasts for the portfolio companies. These proprietary documents enable the analysis to circumvent conventional problems in measuring covenants restrictiveness as encountered in previous studies. For details, please see section 3.2.1.
} 
that the availability of debt financing contributes to boom and bust cycles in buyout markets. This study complements their work by investigating covenants as a further central credit term. This is particularly interesting since covenants - at least from a theoretical point of view - may be used to balance the pro-cyclical developments in the credit terms documented by AXELSON et al. (2010).

This research also enhances the yet limited general literature on financial covenants. ${ }^{369}$ The explicit contribution is to present precise restrictiveness estimates not distorted by common accounting problems on the background of an appealing setting: LBOs concentrate ownership and control, creating an interesting setting for capital structure decisions, which are less distorted by agency conflicts between managers and owners. Further, the negotiations about significant debt amounts in LBOs without already existing debt holder structures and their associated claims provides a clear view on the influence of shareholders and debt holders on covenants.

Taking into account that financial covenants regained high significance as control mechanisms in LBOs after the recent credit crunch, future research seems worthwhile. In terms of data, future research on the LBO capital structure is in the process of being facilitated by the initiative of many regulatory bodies or private equity associations for more transparency in the private equity industry (for example the Walker report in the UK). This will lead to more public data availability but also to a higher willingness of market participants, like e.g. banks, to share their individual transaction data. The success of Dealscan in the US could induce banks in Europe to disclose their transaction data as well.

A first important research step would be to collect a non-sponsored sample with detailed covenant data (including headroom) to analyze the relative restrictiveness of sponsored versus non-sponsored loans. A second step is to enhance this study and test the results in a large sample with 500 or more deals from different institutional settings. In this course, one could analyze the differences in financial covenant structures and restrictiveness across different jurisdictions.

${ }^{369}$ Amongst others see Chava/Roberts (2008), Roberts/Sufi (2009), Demerjian (2010). 
Another important topic, which was briefly covered in the robustness section 6.5.3.3, is the moral hazard problem between lead arrangers and participants. Especially, the relationship between the final hold of the lead arranger and the hidden clauses which impede covenant enforcement are of particular interest.

Furthermore, a very important not sufficiently covered question is the explicit value of financial covenants in general and for LBOs in particular. One could analyze the probability of (payment) default and loss given default of loans of covenant-lite loans as opposed to loans containing maintenance covenants. A related question would be to assess the value of the different types and combinations of financial covenants. For example, it would be very interesting to see the relative value of e.g. a D/EBITDA covenant in relation to a CashFlowCoverage covenant.

A related question, which might be first addressed theoretically, is how private equity groups but also banks react to defaults and what impacts their behavior. Specifically, when do private equity investors inject equity and when do they abandon their investment? The theoretical implications might then be tested against empirical data of defaulted leveraged loans.

Moreover, it seems promising to revisit the findings of DICHEV/SKINNER (2002) and test if private equity groups engage in earnings manipulation to circumvent covenant breach. Ideally, the analysis would cover both levels of principal agent problems, i.e. the conflict between the private equity group and the lenders as well as the conflict between the private equity group and the buyout manager.

In this area of research, it would be interesting to test the signaling theory of covenants, developed by GÂRLEANU/ZWIEBEL (2009). The theoretic argument is that better borrowers accept tighter covenants as they have more information about their future performance and use the restrictiveness of covenants as a signal to lenders to reduce cost of debt. 


\subsection{Implications for Practice}

This thesis has important implications for several practical areas. First, it contributes to the current public debate on the contribution of LBOs to the financial melt-down and is a further point of information for the currently drafted regulation of the European private equity industry. ${ }^{370}$ This study shows that private equity groups significantly increase the financial risk of their target firms with debt provided by banks and thereby tighten the financial covenants. However, at the same time private equity backed companies are not only better prepared and react faster in difficult economic times ${ }^{371}$, but they also receive better credit conditions in terms of lower interest costs, looser financial covenants and covenant clauses which helps them to avoid default and insolvency. Without looking at the exact distinction between the different drivers, THOMAS (2010) shows that $2.8 \%$ of private equity backed businesses defaulted ${ }^{372}$ during the period of 2008 to 2009, while $6.2 \%$ of comparable companies defaulted.

Second, this study provides Limited Partners a rationale to invest in historically top performing, i.e. highly reputed, private equity groups. Transactions that are sponsored by highly reputed private equity groups are granted more leverage, benefit from lower interest costs and enjoy looser financial covenants allowing the private equity sponsor to increase the return on equity for an identical target company. ${ }^{373}$

Third, this is the first academic study to analyze the detailed design of credit contracts in leveraged buyouts. It provides a comprehensive picture of the crucial elements in credit agreements, i.e. financial covenants and clauses that dilute creditor rights. The credit market, especially lenders that are only participating in loans, might gain valuable insights into the design of credit agreements and improve their capabilities to evaluate loans.

\footnotetext{
${ }^{370}$ The European Commission has proposed a Directive on Alternative Investment Fund Managers (AIFM), which is still in the legislative process in September 2010 (latest amendment on $26^{\text {th }}$ of August 2010).

${ }^{371}$ Cf. Steven, et al. (2009).

${ }^{372}$ Default here defined as missed payment or bankruptcy filing.

${ }^{373}$ Cf. Demiroglu/James (2010b).
} 
Finally, being the first comprehensive academic work on financial covenants in leveraged buyouts, this study might serve as an educational tool for private equity professionals, leveraged finance bankers, buyout managers, but also students and researchers in the area of corporate finance in general or private equity in particular. 


\section{APPENDIX}

\begin{tabular}{|c|c|c|c|c|c|c|c|c|c|c|c|c|c|c|c|}
\hline VARIABLES & 1 & 2 & 3 & 4 & 5 & 6 & 7 & 8 & 9 & 10 & 11 & 12 & 13 & 14 & 15 \\
\hline \multicolumn{16}{|l|}{ Target related } \\
\hline EBITDA to sales & $(0.284)$ & $(0.289)$ & $(0.299)$ & $(0.290)$ & $(0.266)$ & $(0.275)$ & $(0.294)$ & $(0.291)$ & $(0.266)$ & $(0.266)$ & $(0.283)$ & $(0.284)$ & $(0.282)$ & $(0.416)$ & $(0.316)$ \\
\hline EBITDA growth & $(0.263)$ & $(0.275)$ & $(0.291)$ & $(0.262)$ & $(0.198)$ & $(0.268)$ & $(0.292)$ & $(0.281)$ & $(0.242)$ & $(0.269)$ & $(0.261)$ & $(0.263)$ & $(0.263)$ & $(0.307)$ & $(0.262)$ \\
\hline Small cap dummy & & $(-0.0259)$ & & & & & & & & & & & & & \\
\hline Large cap dummy & & $(0.0337)$ & & & & & & & & & & & & & \\
\hline Fixed to total assets & & & $(-0.0961)$ & & & & & & & & & & & & \\
\hline Business risk & & & & $(0.0302)$ & & & & & & & & & & & \\
\hline \multicolumn{16}{|l|}{ Transaction related } \\
\hline D/EBITDA & $(-0.205)$ & $(-0.218)$ & $(-0.182)$ & $(-0.205)$ & & $(-0.181)$ & $(-0.274)$ & $(-0.267)$ & $(-0.175)$ & $(-0.187)$ & $(-0.210)$ & $(-0.224)$ & $(-0.205)$ & $(-0.366)$ & $(-0.188)$ \\
\hline $\mathrm{D} / \mathrm{EV}$ & & & & & $(-0.156)$ & & & & & & & & & & \\
\hline All-in drawn spread & & & & & & $(-0.106)$ & & & & & & & & & \\
\hline Share of bank debt & & & & & & & $(-0.127)$ & & & & & & & & \\
\hline Creditor rights dilution & & & & & & & & $(0.217)$ & & & & & & & \\
\hline Strict EBITDA def & & & & & & & & & & & & & & & $(-0.0789)$ \\
\hline Loose EBITDA def & & & & & & & & & & & & & & & $(0.0999)$ \\
\hline \multicolumn{16}{|l|}{ Sponsor related } \\
\hline PEG size & $(0.195)$ & $(0.177)$ & $(0.185)$ & $(0.192)$ & $(0.145)$ & $(0.208)$ & $(0.165)$ & $(0.138)$ & & & & $(0.147)$ & $(0.201)$ & $(0.248)$ & $(0.140)$ \\
\hline PEG lifetime & & & & & & & & & $(0.207)$ & & & & & & \\
\hline PEG number of deals & & & & & & & & & & $(0.186)$ & & & & & \\
\hline BR volume & & & & & & & & & & & & & $(-0.0209)$ & & \\
\hline BR number deals (abs) & & & & & & & & & & & $(0.175)$ & $(0.0861)$ & & & \\
\hline \multicolumn{16}{|l|}{ Lead arranger related } \\
\hline Relative final hold & & & & & & & & & & & & & & $(-0.185)$ & \\
\hline \multicolumn{16}{|l|}{ Macroeconomic related } \\
\hline Credit spread & $(-0.0590)$ & $(-0.0732)$ & $(-0.0494)$ & $(-0.0602)$ & $(-0.0942)$ & $(-0.0389)$ & $(-0.0563)$ & $(-0.0493)$ & $(-0.0779)$ & $(-0.0737)$ & $(-0.0644)$ & $(-0.0625)$ & $(-0.0562)$ & $(-0.124)$ & $(-0.0635)$ \\
\hline
\end{tabular}

Table 34: Source:

Beta coefficients of regressions on the determinants of D/EBITDA headroom LBO dataset 


\section{REFERENCES}

Acharya, V. / Hahn, M. / Kehoe, C. (2010): Corporate Governance and Value Creation: Evidence from Private Equity, unpublished working paper, CEPR.

Achleitner, A.-K. (2002): Handbuch Investment Banking, 3rd edition, Wiesbaden.

Achleitner, A.-K. / Braun, R. / Engel, N. / Figge, C. / Tappeiner, F. (2010): Value Creation in Private Equity Buyouts: Empirical Evidence from Europe, in: The Journal of Private Equity, Spring 2010.

Achleitner, A.-K. / Braun, R. / Hinterramskogler, B. / Tappeiner, F. (2010): Structure and Determinants of Financial Covenants in Leveraged Buyouts, unpublished working paper, Center for Entrepreneurial and Financial Studies (CEFS).

Achleitner, A.-K. / Braun, R. / Tappeiner, F. (2010): Private Equity Group Reputation in Leveraged Buyouts - Financing Structure and Lender Control in Europe, unpublished working paper, Center for Entrepreneurial and Financial Studies (CEFS).

Achleitner, A.-K. / Schraml, S. / Tappeiner, F. (2008): Private Equity Minority Investments in Larger Family Firms: What Influences the Attitude of the Family Firm Owners?, unpublished working paper, Center for Entrepreneurial and Financial Studies (CEFS).

Aghion, P. / Bolton, P. (1992): An Incomplete Contracts Approach to Financial Contracting, in: Review of Economic Studies, 59 (200), p. 473-494.

Aghion, P. / Hart, O. / Moore, J. (1992): The Economics of Bankruptcy Reform, in: Journal of Law, Economics, \& Organization, 8 (3), p. 523-546.

Akerlof, G. (1970): The Market for 'Lemons': Quality Uncertainty and the Market Mechanism, in: Quarterly Journal of Economics, 84, p. 488-500.

Allen, F. / Bartiloro, L. / Kowalewski, O. (2006): The Financial System of the EU 25, unpublished working paper, Wharton School, University of Pennsylvania.

Axelson, U. / Jenkinson, T. / Strömberg, P. / Weisbach, M. S. (2010): Borrow Cheap, Buy High? The Determinants of Leverage and Pricing in Buyouts, unpublished working paper, Stockholm School of Economics.

Axelson, U. / Strömberg, P. / Weisbach, M. S. (2009): Why Are Buyouts Levered? The Financial Structure of Private Equity Funds, in: The Journal of Finance, 64 (4), p. 1549-1582.

Begley, J. (1990): Debt Covenants and Accounting Choice, in: Journal of Accounting and Economics, 12 (1-3), p. 125-139.

Begley, J. / Chamberlain, S. (2006): The Use of Debt Covenants in Public Debt: The Role of Accounting Quality and Reputation, unpublished working paper, Sauder School of Business, University of British Columbia. 
Beneish, M. D. / Press, E. G. (1993): Costs of Technical Violation of AccountingBased Debt Covenants, in: The Accounting Review, 68 (2), p. 233-257.

Beneish, M. D. / Press, E. G. (1995): The Resolution of Technical Default, in: The Accounting Review, 70, p. 337-353.

Benston, G. J. / Smith, C. W. (1976): A Transactions Cost Approach to the Theory of Financial Intermediation, in: The Journal of Finance, 31 (2), p. 215-231.

Berg, A. / Gottschalg, O. F. (2005): Understanding Value Generation in Buyouts, in: Journal of Restructuring Finance, 2 (1), p. 9-37.

Berger, A. N. (1999): The "Big Picture" About Relationship-Based Finance, unpublished working paper, Federal Reserve Bank of Chicago.

Berlin, M. / Mester, L. J. (1992): Debt Covenants and Renegotiation, in: Journal of Financial Intermediation, 2 (2), p. 95-133.

Berndt, A. / Gupta, A. (2009): Moral Hazard and Adverse Selection in the Originateto-Distribute Model of Bank Credit, in: Journal of Monetary Economics, 56 (5), p. 725-743.

Besanko, D. / Thakor, A. V. (1987): Collateral and Rationing: Sorting Equilibria in Monopolistic and Competitive Credit Markets, in: International Economic Review, 28.3, p. 671-689.

Bharath, S. / Dahiya, S. / Saunders, A. / Srinivasan, A. (2007): So What Do I Get? The Bank's View of Lending Relationships, in: Journal of Financial Economics, 85 (2), p. 368-419.

Bhattacharya, S. / Thakor, A. V. (1993): Contemporary Banking Theory, in: Journal of Financial Intermediation, 3, p. 2-50.

Billett, M. T. / King, T.-H. D. / Mauer, D. C. (2007): Growth Opportunities and the Choice of Leverage, Debt Maturity, and Covenants, in: The Journal of Finance, 62, p. 697-730.

Black, F. / Scholes, M. (1973): The Pricing of Options and Corporate Liabilities, in: Journal of Political Economy, 81 (3), p. 637-654.

Bolton, P. / Scharfstein, D. S. (1995): Optimal Debt Structure and the Number of Creditors, in: Journal of Political Economy, 104 (1), p. 1-25.

Boot, A. W. A. (2000): Relationship Banking: What Do We Know?, in: Journal of Financial Intermediation, 9 (1), p. 7-25.

Boot, A. W. A. / Thakor, A. V. (2000): Can Relationship Banking Survive Competition?, in: The Journal of Finance, 55 (2), p. 35. 
Bradley, M. H. / Roberts, M. R. (2004): The Structure and Pricing of Corporate Debt Covenants, unpublished working paper, The Fuqua School of Business, Duke University.

Brinkhuis, S. / De Maeseneire, W. (2009): What Drives Leverage in Leveraged Buyouts? An Analysis of European LBOs' Capital Structure, unpublished working paper, Erasmus University Rotterdam.

Cameron, A. C. / Trivedi, P. K. (2009): Microeconometrics Using Stata, College Station.

Carey, M. / Post, M. / Sharpe, S. A. (1998): Does Corporate Lending by Banks and Finance Companies Differ? Evidence on Specialization in Private Debt Contracting, in: The Journal of Finance, 53 (3), p. 845-878.

Carter, R. B. / Dark, F. H. / Singh, A. K. (1998): Underwriter Reputation, Initial Returns, and the Long-Run Performance of IPO Stocks, in: The Journal of Finance, 53 (1), p. 285-311.

Chan, Y.-S. / Kanatas, G. (1985): Asymmetric Valuations and the Role of Collateral in Loan Agreements, in: The Journal of Finance, 17.1, p. 84-95.

Chava, S. / Kumar, P. / Warga, A. (2010): Agency Costs and the Pricing of Bond Covenants, in: Review of Financial Studies, forthcoming.

Chava, S. / Roberts, M. R. (2008): How Does Financing Impact Investment? The Role of Debt Covenant Violations, in: The Journal of Finance, 63 (5), p. 2085-2121.

Chen, K. C. / Wei, K. C. (1993): Creditors' Decisions to Waive Violations of Accounting-Based Debt Covenants, in: The Accounting Review, 68, p. 218-232.

Chung, J.-W. / Sensoy, B. A. / Stern, L. H. / Weisbach, M. S. (2010): Incentives of Private Equity General Partners from Future Fundraising, unpublished working paper, The Ohio State University.

Clifford Chance (2007): Financial Covenants under Stress, publication May 2007, available from Clifford Chance upon request.

Coase, R. (1937): The Nature of the Firm, in: Economica, 4 (16), p. 386-405.

Cornell, B. / Shapiro, A. C. (1987): Corporate Stakeholders and Corporate Finance, in: Financial Management, 16 (1), p. 5-14.

Cotter, J. F. / Peck, S. W. (2001): The Structure of Debt and Active Equity Investors: The Case of Buyout Specialists, in: Journal of Financial Economics, 59, p. 101-147.

De Matos, J. A. (2001): Theoretical Foundations of Corporate Finance, Princeton.

Dechow, P. M. (1994): Accounting Earnings and Cash Flows as Measures of Firm Performance: The Role of Accounting Accruals, in: Journal of Accounting and Economics, 18, p. 3-42. 
Dechow, P. M. / Ge, W. / Schrand, C. (2009): Understanding Earnings Quality: A Review of the Proxies, their Determinants and their Consequences, unpublished working paper, University of California, Berkley.

Dechow, P. M. / Kothari, S. P. / Watts, R. L. (1998): The Relation between Earnings and Cash Flows, in: Journal of Accounting and Economics, 25, p. 133-168.

Demerjian, P. (2007): Financial Ratios and Credit Risk: The Selection of Financial Ratio Covenants in Debt Contracts, unpublished working paper, Stephen M. Ross School of Business - University of Michigan.

Demerjian, P. (2010): Financial Covenants, Credit Risk, and the Resolution of Uncertainty, unpublished working paper, Stephen M. Ross School of Business - University of Michigan.

Demiroglu, C. / James, C. M. (2010a): The Information Content of Bank Loan Covenants, in: Review of Financial Studies, forthcoming.

Demiroglu, C. / James, C. M. (2010b): The Role of Private Equity Group Reputation in Buyout Financing, in: Journal of Financial Economics, 96, p 306-330.

Dennis, S. A. / Mullineaux, D. J. (2000): Syndicated Loans, in: Journal of Financial Intermediation, 9, p. 404-426.

Dessein, W. (2005): Information and Control in Ventures and Alliances, in: Journal of Finance, 60 (5), p. 2513-2549.

Diamond, D. W. (1984): Financial Intermediation and Delegated Monitoring, in: Review of Economic Studies, 51 (3), p. 393-414.

Diamond, D. W. (1989): Reputation Acquisition in Debt Markets, in: Journal of Political Economy, 97 (4), p. 828-862.

Diamond, D. W. (1991): Monitoring and Reputation: The Choice between Bank Loans and Directly Placed Debt, in: Journal of Political Economy, 99 (4), p. 689-721.

Diamond, D. W. (1993): Seniority and Maturity of Debt Contracts, in: Journal of Financial Economics, 33 (3), p. 341-368.

Dichev, I. D. / Skinner, D. J. (2002): Large-Sample Evidence on the Debt Covenant Hypothesis, in: Journal of Accounting Research, 40 (4), p. 1091-1123.

Diller, C. / Kaserer, C. (2009): What Drives Private Equity Returns? Fund Inflows, Skilled GPs, and / or Risk?, in: European Financial Management, 15 (3).

Djankov, S. / McLiesh, C. / Shleifer, A. (2007): Private Credit in 129 Countries, in: Journal of Financial Economics, 84, p. 299-329.

Driessen, J. / Phalippou, L. / Tse-Chun, L. (2009): A New Method to Estimate Risk and Return of Non-Traded Assets from Cash Flows: The Case of Private Equity Funds, unpublished working paper, Amsterdam Business School. 
Drucker, S. / Puri, M. (2009): On Loan Sales, Loan Contracting, and Lending Relationships, in: Review of Financial Studies, 22 (7), p. 2835-2872.

Eilers, S. / Koffka, N. M. / Mackensen, M. (2009): Private Equity - Unternehmenskauf, Finanzierung, Restrukturierung, Exitstrategien, München.

Eisenhardt, K. M. (1989): Agency Theory: An Assessment and Review, in: Academy of Management Review, 14 (1), p. 57-74.

Fairchild, R. (2007): Managerial Overconfidence, Agency Problems, Financing Decisions and Firm Performance, unpublished working paper, University of Bath, School of Management.

Fama, E. F. / Miller, M. (1972): The Theory of Finance, New York.

Fang, L. / Ivashina, V. / Lerner, J. (2010): An Unfair Advantage? Combining Banking with Private Equity Investing, unpublished working paper, INSEAD, Harvard University, NBER.

Feinendegen, S. / Schmidt, D. / Wahrenburg, M. (2003): Die Vertragsbeziehungen zwischen Investoren und Europäischen Venture Capital-Fonds: Eine empirische Untersuchung und Klassifizierung unterschiedlicher Vertragsmuster, in: ZfB, 73 (11), p. 1167-1195.

Fenn, G. W. / Liang, N. / Prowse, S. (1995): The Economics of the Private Equity Market, unpublished working paper, Board of Governors of the Federal Reserve System.

Frankel, R. M. / Litov, L. P. (2007): Financial Accounting Characteristics and Debt Covenants, unpublished working paper, Washington University.

Friedman, H. (2007): Does Overconfidence Affect Entrepreneurial Investment, unpublished working paper, Wharton School, University of Pennsylvania.

Galai, D. / Masulis, R. W. (1976): The Option Pricing Model and the Risk Factor of Stock, in: Journal of Financial Economics, 3, p. 53-81.

Gârleanu, N. / Zwiebel, J. (2009): Design and Renegotiation of Debt Covenants, in: Review of Financial Studies, 22, p. 749-781.

Geidner, A. (2009): Der Wandel Der Unternehmensführung in Buyouts - Eine Untersuchung Private-Equity-Finanzierter Desinvestitionen, Dissertation, München.

Gertner, R. / Kaplan, S. N. (1996): The Value-Maximizing Board, unpublished working paper, University of Chicago and NBER.

Gertner, R. / Scharfstein, D. S. (1991): A Theory of Workouts and the Effects of Reorganization Law, in: Journal of Finance, 46 (4), p. 1189-1222.

Gompers, P. / Lerner, J. (1999): An Analysis of Compensation in the U.S. Venture Capital Partnership, in: Journal of Financial Economics, 51 (1), p. 3-44. 
Gompers, P. / Lerner, J. (2004): The Venture Capital Cycle, Cambridge/MA.

Gorton, G. B. / Pennacchi, G. G. (1995): Banks and Loan Sales - Marketing Nonmarketable Assets, in: Journal of Monetary Economics, 35, p. 389-411.

Gottschalg, O. F. / Phalippou, L. (2009): The Performance of Private Equity Funds, in: Review of Financial Studies, 22 (4), p. 1747-1776.

Graham, J. / Harveya, C. / Rajgopalc, S. (2005): The Economic Implications of Corporate Financial Reporting, in: Journal of Accounting and Economics, 40 (1-3), p. 3-73.

Grossman, S. J. / Hart, O. D. (1986): The Costs and Benefits of Ownership: A Theory of Vertical and Lateral Integration, in: Journal of Political Economy, 94 (4), p. 691719.

Guo, S. / Hotchkiss, E. S. / Song, W. (2010): Do Buyouts (Still) Create Value?, in: The Journal of Finance, forthcoming.

Hart, O. (1995): Firms, Contracts, and Financial Structure, Oxford and New York.

Hart, O. (2000): Financial Contracting, unpublished working paper, Kellogg Northwestern University.

Hart, O. / Moore, J. (1990): Property Rights and the Nature of the Firm, in: Journal of Political Economy, 98 (6), p. 1119.

Hart, O. / Moore, J. (1999): Foundations of Incomplete Contracts, in: Review of Economic Studies, 66, p. 115-138.

Holmström, B. / Tirole, J. (1997): Financial Intermediation, Loanable Funds, and the Real Sector, in: Quarterly Journal of Economics, 112 (3), p. 663-691.

Hong, H. A. / Hung, M. / Zhang, J. (2009): The Impact of Financial Covenants on the Use of Accounting Conservatism in Debt Contracting: International Evidence, unpublished working paper, University of Southern California.

Ivashina, V. / Kovner, A. (2010): The Private Equity Advantage: Leveraged Buyout Firms and Relationship Banking, in: Review of Financial Studies, forthcoming.

Ivashina, V. / Scharfstein, D. S. (2010): Bank Lending During the Financial Crisis of 2008, in: Journal of Financial Economics, 97 (3), p. 319-338.

Ivashina, V. / Sun, Z. (2009): Institutional Demand Pressure and the Cost of Leveraged Loans, in: Journal of Financial Economics, forthcoming.

Jensen, M. (1989): The Eclipse of Public Corporation, in: Harvard Business Review, September-October, p. 61-74.

Jensen, M. C. (1986): Agency Costs of Free Cash Flow, Corporate Finance, and Takeovers, in: American Economic Review, 76 (2), p. 323-329. 
Jensen, M. C. / Meckling, W. H. (1976): Theory of the Firm: Managerial Behavior, Agency Costs and Ownership Structure, in: Journal of Financial Economics, 3 (4), p. 305-360.

Jonsson, L. (2005): Tax Structuring Is Key to Private Equity Success, in: International Tax Review, 51.

Kahan, M. / Tuckman, B. (1993): Private Vs. Public Lending: Evidence from Covenants, in: The Yearbook of Fixed Income Investing, p. 253-274.

Kale, J. R. / Noe, T. H. / Ramirez, G. G. (1991): The Effect of Business Risk on Corporate Capital Structure: Theory and Evidence, in: The Journal of Finance, 46 (5), p. 1693-1715.

Kaplan, S. N. (1997): The Evolution of U.S. Corporate Governance: We Are All Henry Kravis Now, in: The Journal of Private Equity, Fall, p. 7-14.

Kaplan, S. N. / Ruback, R. S. (1995): The Valuation of Cash Flow Forecasts: An Empirial Analysis, in: The Journal of Finance, 50 (4), p. 1059-1093.

Kaplan, S. N. / Schoar, A. (2005): Private Equity Performance: Returns, Persistence, and Capital Flows, in: Journal of Finance, 60 (4), p. 1791-1823.

Kaplan, S. N. / Stein, J. C. (1993): The Evolution of Buyout Pricing and Financial Stucture in the 1980s, in: Quarterly Journal of Economics, 108 (2), p. 313-357.

Kaplan, S. N. / Strömberg, P. (2009): Leveraged Buyouts and Private Equity, in: Journal of Economic Perspectives, 23 (1), p. 121-146.

Kaserer, C. / Achleitner, A.-K. / von Einem, C. / Schiereck, D. (2007): Private Equity in Deutschland, Norderstedt.

Klöckner, O. (2009): Buy-Outs in Family Businesses - Changes in Corporate Governance, Instruments in Managerial Control, and Financial Practices, Dissertation, München.

Kovner, A. (2008): Multiples, Management or Leverage? A Decomposition of LBO Returns, unpublished working paper (preliminary results), Harvard Business School.

Kühn, C. (2006): Capital Structure Decisions in Institutional Buyouts. Aachen.

La Porta, R. / Lopez-De-Silanes, F. / Shleifer, A. / Vishny, R. W. (1997): Legal Determinants of External Finance, in: The Journal of Finance, 52 (3), p. 1131-1150.

Lai, A. / Bavaria, S. (2007): The Leveraging of America: Covenant-Lite Loan Structures Diminish Recovery Prospects, Standard \& Poor's.

Landier, A. / Thesmar, D. (2009): Financial Contracting with Optimistic Entrepreneurs, in: Review of Financial Studies, 22 (1), p. 117-150. 
Lawler, P. (2007): What Private Equity Firms Want in a Lender, in: Commercial Lending Review, 22 (1), p. 9-17.

Lee, S. W. / Mullineaux, D. J. (2004): Monitoring, Financial Distress, and the Structure of Commercial Lending Syndicates, in: Financial Management, 33, p. 107-130.

Leland, H. E. (1994): Corporate Debt Value, Bond Covenants, and Optimal Capital Structure, in: Journal of Finance, 49 (4), p. 1213-1252.

Leland, H. E. / Pyle, D. H. (1977): Informational Asymmetries, Financial Structure, and Financial Intermediation, in: Journal of Finance, 32 (2), p. 371-387.

Lerner, J. / Gurung, A. (2008): The Global Economic Impact of Private Equity Report 2008, Globalization of Alternative Investments, World Economic Forum.

Lerner, J. / Leamon, A. / Hardymon, F. (2010): Private Equity and Venture Capital in the Wake of the Crisis, unpublished working paper, Harvard Business School.

Lerner, J. / Sorensen, M. / Strömberg, P. (2008): Private Equity and Long-Run Investment: The Case of Innovation, in: The Journal of Finance, forthcoming.

Lerner, J. / Stromberg, P. / Sorensen, M. (2009): What Drives Private Equity Activity and Success Globally?, unpublished working paper, World Economic Forum, Geneva and New York.

Liu, X. (2009): The Capital Structure of Private Equity-Backed Firms, unpublished working paper, Imperial College Business School.

Ljungqvist, A. / Richardson, M. (2003): The Cash Flow, Return and Risk Characteristics of Private Equity, unpublished working paper, NYU.

LMA (2007): Guide to Syndicated Leverage Finance, p. 11.

Lutz, E. / Achleitner, A.-K. (2009): Angels of Demons? Evidence on the Impact of Private Equity Firms on Employment, in: ZfB - Zeitschrift für Betriebswirtschaft (5).

Malitz, I. (1986): On Financial Contracting: The Determinants of Bond Covenants, in: Financial Management, 15, p. 18-25.

Malitz, I. (1994): The Modern Role of Bond Covenants, Charlottesville.

Maskin, E. / Tirole, J. (1999): Unforeseen Contingencies and Incomplete Contracts, in: Review of Economic Studies, 66, p. 83-114.

Masulis, R. W. (1980): The Effects of Capital Structure Change on Security Prices, in: Journal Financial Economics, 8, p. 139-178.

Mather, P. (1999): Financial Covenants and Related Contracting Processes in the Australian Private Debt Market: An Experimental Study, in: Accounting and Business Research, 30 (1), p. 19-42. 
Metrick, A. / Yasuda, A. (2010): The Economics of Private Equity Funds, in: Review of Financial Studies, forthcoming.

Miller, M. H. (1977): Debt and Taxes, in: Journal of Finance, 32 (2), p. 261-275.

Miller, S. / Chew, W. (2009): A Guide to the Loan Market, Standard \& Poor's.

Mittendorfer, R. (2007): Praxishandbuch Akquisitionsfinanzierung, Wiesbaden.

Modigliani, F. / Miller, M. H. (1958): The Cost of Capital, Corporation Finance and the Theory of Investment, in: The American Economic Review, 48 (3), p. 261-297.

Müller, K. (2008): Investing in Private Equity Partnerships -the Role of Monitoring and Reporting, München.

Myers, S. / Majluf, N. (1984): Corporate Financing and Investment Decisions When Firms Have Information That Investors Do Not Have, in: Journal of Financial Economics, 13 (2), p. 187-221.

Myers, S. C. (1977): Determinants of Corporate Borrowing, in: Journal of Financial Economics, 5 (2), p. 146-175.

Myers, S. C. (1984): The Capital Structure Puzzle, in: Journal of Finance, 39 (3), p. 575-592.

Nash, R. C. / Netter, J. M. / Poulsen, A. B. (2003): Determinants of Contractual Relations between Shareholders and Bondholders: Investment Opportunities and Restrictive Covenants, in: Journal of Corporate Finance, 9, p. 201-232.

Nikoskelainen, E. / Wright, M. (2005): The Impact of Corporate Governance Mechanisms on Value Increase in Leveraged Buyouts, unpublished working paper,

Nini, G. / Smith, D. C. / Sufi, A. (2007): Creditor Control Rights and Firm Investment Policy, unpublished working paper, University of Chicago.

Panyagometh, K. / Roberts, G. (2008): Loan Syndicate Structure: Evidence from Ex Post Data, unpublished working paper, York University - Schulich School of Business.

Park, C. (2000): Monitoring and Structure of Debt Contracts, in: Journal of Finance, 55 (5), p. 2157-2195.

Parsons, C. / Titman, S. (2008): Empirical Capital Structure: A Review, in: Foundations and Trends in Finance, 3 (1).

Polenberg, R. / Lukatsky, M. / Gupte, S. C. (2010): A Primer for the European Syndicated Loan Market, Standard \& Poor's.

Rajan, R. (1992): Insiders and Outsiders: The Choice between Informed and Arm'sLength Debt, in: Journal of Finance, 7 (2), p. 117-161.

Rajan, R. / Winton, A. (1995): Covenants and Collateral as Incentives to Monitor, in: Journal of Finance, 50.4, p. 1113-1144. 
Rajan, R. / Zingales, L. (1995): What Do We Know About Capital Structure? Some Evidence from International Data, in: The Journal of Finance, 50 (5), p. 1421-1460.

Rauh, J. D. / Sufi, A. (2009): Capital Structure and Debt Structure, unpublished working paper, Kellogg School of Management, University of Chicago Booth School of Business and NBER.

Richter, R. / Furubotn, E. G. (1999): Neue Institutionenökonomik. Tübingen.

Roberts, M. R. / Sufi, A. (2009): Renegotiation and Financial Contracts: Evidence from Private Credit Agreements, in: Journal of Financial Economics, 93, p. 159-184.

Rosenbaum, J. / Pearl, J. (2009): Investment Banking - Valuation, Leveraged Buyouts, and Mergers\&Acquisitions. Hoboken, New Jersey.

Ross, S. (1973): The Economic Theory of Agency: The Principal's Problem, in: American Economic Review, 63 (2), p. 134-139.

Rudolph, B. (2006): Unternehmensfinanzierung und Kapitalmarkt. Tübingen.

Rudolph, B. (2008): Funktionen und Regulierung der Finanzinvestoren, in: Zeitschrift für Unternehmens- und Gesellschaftsrecht, 2-3, p. 161-184.

Sahlman, W. (1990): The Structure and Governance of Venture-Capital Organizations, in: Journal of Financial Economics, 27 (2), p. 473-521.

Schell, J. M. (2006): Private Equity Funds - Business Structure and Operations. New York.

Smith, C. W. J. / Warner, J. B. (1979): On Financial Contracting: An Analysis of Bond Covenants, in: Journal of Financial Economics, 7 (2), p. 117- 161.

Sridhar, S. S. / Magee, R. P. (1996): Financial Contracts, Opportunism, and Disclosure Management in: Review of Accounting Studies, 1 (3), p. 225-258.

Steffen, S. (2008): What Drives Syndicated Loan Spreads? Moral Hazard and Lending Relationships, unpublished working paper,

Steven, D. J. / Haltiwanger, J. / Jarmin, J. / Lerner, J. / Javier, M. (2009): Private Equity, Jobs and Productivity, in: The Global Economic Impact of Private Equity Report 2009.

Stiglitz, J. (1974): On the Irrelevance of Corporate Financial Policy, in: American Economic Review, 64 (4), p. 851-866.

Strömberg, P. (2008): The New Demography of Private Equity, unpublished working paper, Swedish Institute for Financial Research, Stockholm School of Economics, CEPR, NBER.

Sufi, A. (2007): Information Asymmetry and Financing Arrangements: Evidence from Syndicated Loans, in: The Journal of Finance, 62 (2), p. 629 - 668. 
Sweeney, A. P. (1994): DebtCovenant Violations and Managers' Accounting Responses, in: Journal of Accounting and Economis, 17, p. 281-308.

Thakor, A. V. (1996): Capital Requirements, Monetary Policy, and Aggregate Bank Lending: Theory and Empirical Evidence, in: The Journal of Finance, 51 (1), p. 279324.

Thomas, J. M. (2010): The Credit Performance of Private Equity-Backed Companies in the 'Great Recession' of 2008-2009, unpublished working paper, Private Equity Council.

Tirole, J. (2006): The Theory of Corporate Finance. Princeton, New Jersey.

Townsend, R. (1979): Optimal Contracts and Competitive Markets with Costly State Verification, in: Journal of Economic Theory, 21, p. 265-293.

von Neumann, J. / Morgenstern, O. (1953): Theory of Games and Economic Behavior. Princeton.

Watts, R. L. / Zimmerman, J. L. (1990): Positive Accounting Theory: A Ten Year Perspective, in: The Accounting Review, 65 (1), p. 131-156.

Williamson, O. (1979): Transaction-Cost Economies: The Governance of Contractual Relations, in: Journal of Law and Economics, 22, p. 233-261.

Wooldridge, J. M. (2002): Econometric Analysis of Cross Section and Panel Data. Cambridge, Massachusetts.

Wooldridge, J. M. (2006): Introductory Econometrics - a Modern Approach. Cambridge, Massachusetts.

Wright, M. / Robbie, K. (1998): Venture Capital and Private Equity: A Review and Synthesis, in: Journal of Business Finance \& Accounting, 25 (5-6), p. 521-570.

Zhang, Z. (2009): Recovery Rates and Macroeconomic Conditions: The Role of Loan Covenants, unpublished working paper, Carroll School of Management, Boston College. 